\title{
Copper, Zinc and Iron Contamination in Wellington Streams After Rainfall Events
}

\author{
by
}

Omar Ahmed Alsager

TE WHARE WĀNANGA O TE ŪPOKO O TE IKA A MĀUI

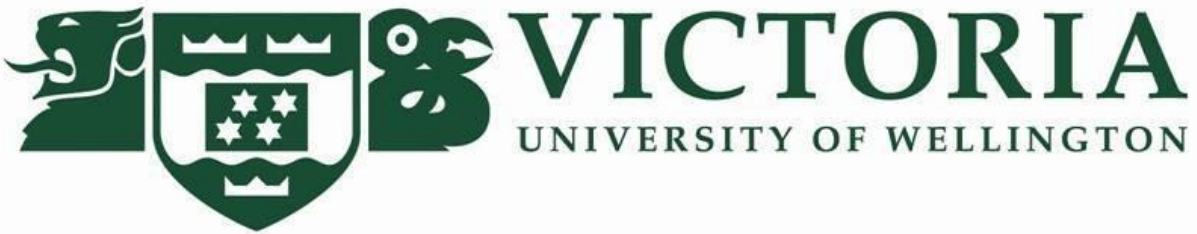

A Thesis

Submitted to Victoria University of Wellington in partial fulfilment of the requirements of the degree of Masters of Science in Chemistry

Victoria University of Wellington 


\begin{abstract}
This work set out to determine the concentrations of dissolved copper $(\mathrm{Cu})$, zinc $(\mathrm{Zn})$ and iron (Fe) during base and wet weather flow at streams throughout the Wellington region. The secondary objective was to investigate possible sources of heavy metals during rainfall events.

The concentrations of the three dissolved trace metals $\mathrm{Cu}, \mathrm{Zn}$ and Fe were measured at 13 sites on five streams during base flow conditions and during runoff events (wet weather flow) in the Wellington region between January and July 2011. More than 240 base flow and 100 wet weather flow samples have been analysed for the three dissolved metals. Additionally, rainfall, roof runoff and paved surface runoff samples have been collected and analysed. The analysis was performed by Flame Atomic Absorption Spectroscopy (FAAS). A pre-concentration procedure using Chelex-100, a chelating polymeric resin bead, was developed and successfully used to enhance the concentrations of dissolved $\mathrm{Cu}$ and dissolved $\mathrm{Zn}$. The recorded data were compared to the recommended long-term (chronic) toxicity triggers; the Australian and New Zealand Environment and Conservation Council freshwater toxicity trigger values (ANZECC (2000) TV) for dissolved $\mathrm{Cu}$ and $\mathrm{Zn}$, and the Canadian trigger value (CTV) for dissolved Fe. Additionally, the concentrations of dissolved $\mathrm{Cu}$ and $\mathrm{Zn}$ in storm water samples were compared against the recommended short-term (acute) toxicity triggers, the United States Environmental Protection Agency (USEPA 2006) Criteria Maximum Concentrations (CMC).

The medians of dissolved heavy metals concentrations; $\mathrm{Cu}, \mathrm{Zn}$, and $\mathrm{Fe}$, all of which are potentially toxic to aquatic life, exceeded the long-term (chronic) toxicity guidelines at one of the studied sites for $\mathrm{Fe}$, nine sites $(69 \%)$ for $\mathrm{Cu}$ and 10 sites (77\%) for $\mathrm{Zn}$ in base flow conditions. Comparison of base flow monitoring data to previous reports showed that the concentrations of the studied metals have increased over the last five years.
\end{abstract}


Storm water (wet weather flow conditions) contained elevated levels of dissolved heavy metals in comparison to base flow concentrations which is consistent with what has been reported previously. Dissolved $\mathrm{Cu}$ and $\mathrm{Zn}$ exceeded the acute toxicity criteria at sites of suburban residential areas. The median of dissolved $\mathrm{Fe}$ concentration exceeded the sustained toxicity exposure trigger at eight of the studied sites $(61 \%)$.

Distinct catchment type contaminant concentrations (dissolved $\mathrm{Cu}$ and $\mathrm{Zn}$ ) were observed during storm runoff events with a concentration pattern of suburban residential > commercial > light residential > rural catchment. Dissolved Fe exhibited a similar pattern but in this case the concentration in rural catchments was higher than in light residential catchments. These observations were attributed to the high traffic of vehicles passing nearby the area; accumulated particulate materials; and corrosion of materials containing heavy metals, such as galvanised and copper roofs, gutter systems and building construction materials. The strongest and most obvious first flush effect was observed with dissolved $\mathrm{Cu}$ followed by $\mathrm{Zn}$ where the phenomenon was observed in six storm runoff events for $\mathrm{Cu}$ and five events for $\mathrm{Zn}$. The first flush effect of dissolved Fe was present in three out of eight storm runoff events. The concentrations of dissolved metals were of the same order of magnitude as those previously reported for the Wellington region, but this work recorded the highest expected concentrations, particularly, for dissolved Fe. The reported data are consistent with data sets from other New Zealand regions.

The investigation of possible sources of dissolved heavy metals in storm runoff samples showed that rainfall water contained markedly elevated concentrations of dissolved $\mathrm{Zn}$ and smaller $\mathrm{Cu}$ concentrations, 0.04-0.075 and 0.0018-0.01 mg/L respectively, in comparison to the ANZECC (2000) TVs, 0.008 and $0.0014 \mathrm{mg} / \mathrm{L}$ respectively. The concentrations of dissolved Fe were below the CTV level of 0.3 $\mathrm{mg} / \mathrm{L}$. Most studies conducted in New Zealand did not take into account the atmospheric precipitation contribution to the elevated concentrations of dissolved metals during runoff events. Roof runoff samples had similar dissolved $\mathrm{Cu}$ and $\mathrm{Fe}$ concentration to those recorded in atmospheric rainfall water, but $\mathrm{Zn}$ was found to be higher in galvanised roof runoff. First flush samples from roof runoff had higher concentrations of all three metals than the delayed runoff samples, indicating the presence of accumulated particles containing metals. Paved surface runoff samples 
had concentrations of dissolved $\mathrm{Cu}$ and $\mathrm{Zn}$ higher than the chronic toxicity triggers, but the medians did not exceed the acute toxicity guidelines. The value of the median for the concentrations of dissolved Fe was below the CTV criteria. Similar results have been published for surface runoff in New Zealand and the international literature related to this field. 


\section{Acknowledgments}

First and foremost, I want to thank my parents for their never-ending love and encouragement of my studies throughout the years; for their adventurous natures, and for their support of my journey in New Zealand.

Words cannot express the gratitude I have for my supervisor, Dr David Weatherburn, for making this thesis possible through his wealth of academic experience in the field of environmental and analytical chemistry. He was always there and patient with me anytime throughout my consultation period with him whenever I had vague problems.

Many thanks go to my country, particularly the King Abdul Aziz City for Science and Technology for giving me this opportunity by providing the scholarship and the financial support.

I greatly thank my friends Giancarlo Barassi, Dr. Carla Fonseca-Paris and Dr. Mathew Cairns for their unrelenting assistance during the entire period of my laboratory work and writing.

Appreciation also goes to Ted Taylor and Jon Marks from the Greater Wellington Regional Council for the assistance in providing information needed throughout the entire period of my work on this project. 


\section{Contents}

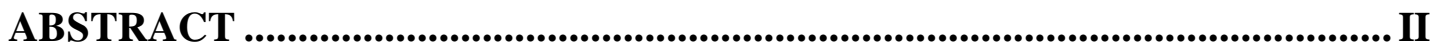

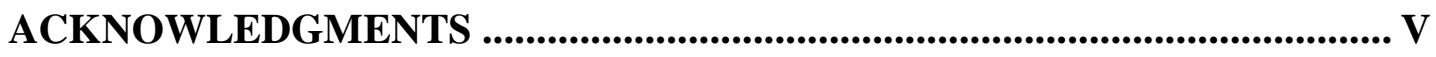

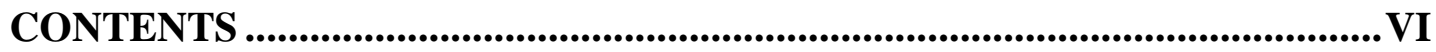

LIST OF FIGURES

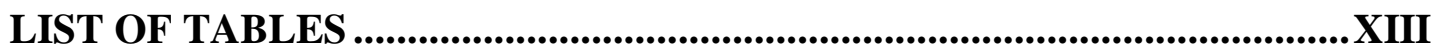

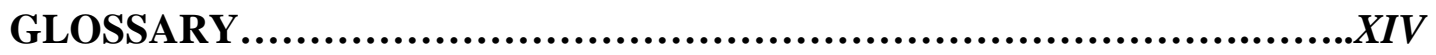

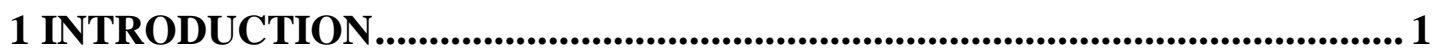

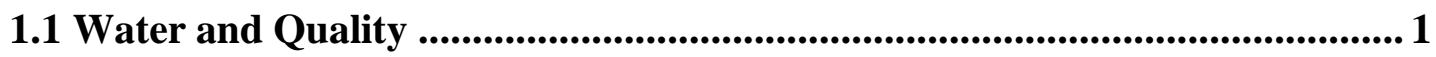

1.2 Objectives and Research Questions.........................................................2

1.3 Research Approach ......................................................................................................... 3

1.4 Study Area and Sites Classifications ............................................................. 4

1.5 Heavy Metals in Natural and Storm Waters: Sources and Effects ............... 12

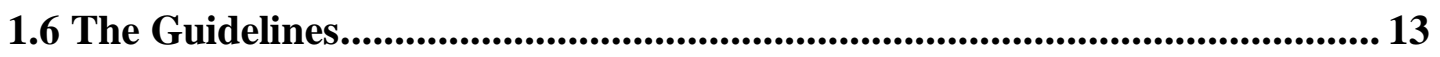

2 SCOPE OF FIRST FLUSH AND LITERATURE REVIEW ....................... 16

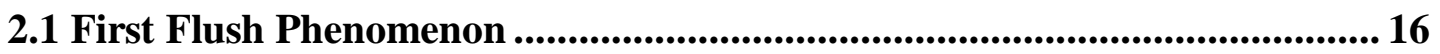

2.2 Literature Review .................................................................................................... 20

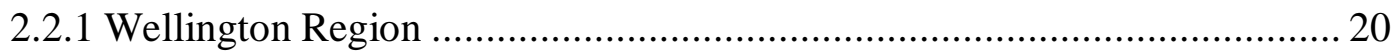

2.2.2 Other New Zealand Literature ............................................................ 22

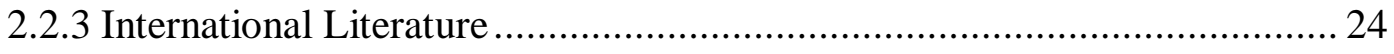

2.2.4 Summary of the Literature .............................................................. 27

3 FIELD WORK AND EXPERIMENTAL ....................................................... 28

3.1 Field Work and Sampling Strategies................................................................ 28

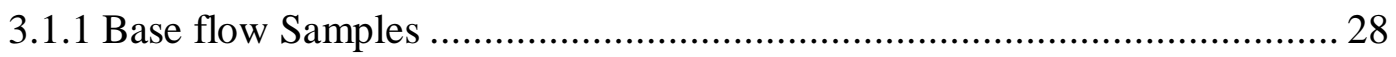


3.1.2 Storm Runoff Samples

3.1.3 Continuous Monitoring of Storm Runoff: First Flush and Composite

Samples 30

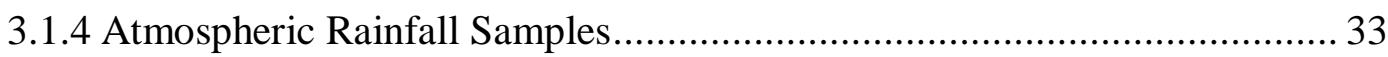

3.1.5 Roof Runoff Samples. ...................................................................... 34

3.1.6 Paved Surface Runoff Samples ................................................................. 35

3.2 Laboratory Work ............................................................................... 36

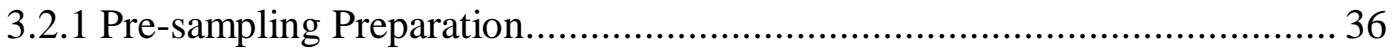

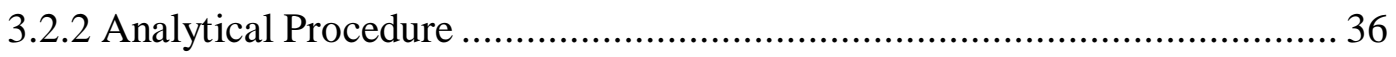

3.2.2.1 Determination of Dissolved Metal Concentrations ............................ 36

4 BASE FLOW AND WET WEATHER MONITORING OUTCOME............ 45

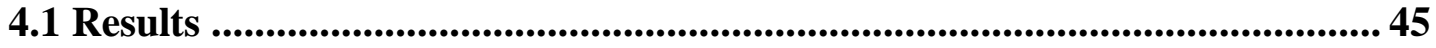

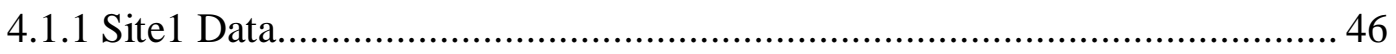

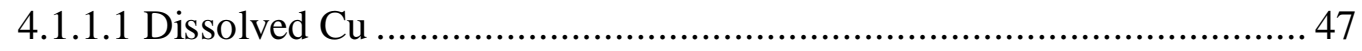

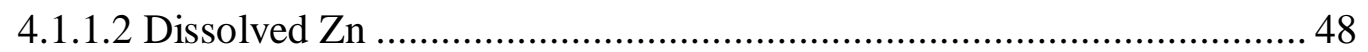

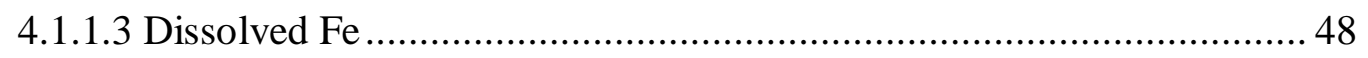

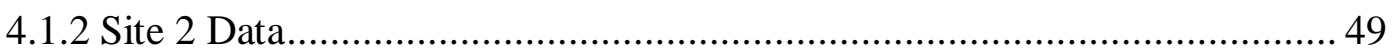

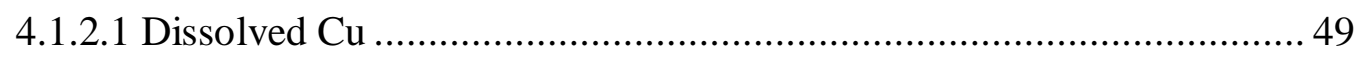

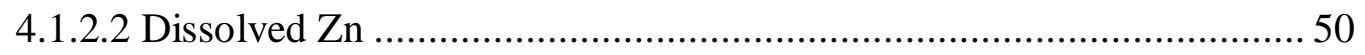

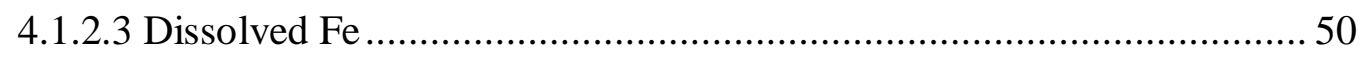

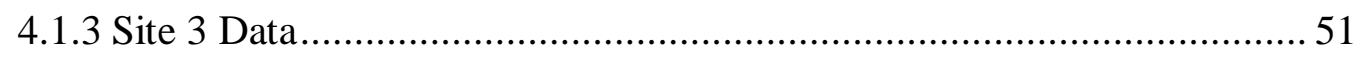

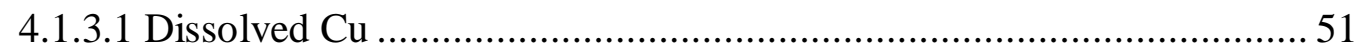

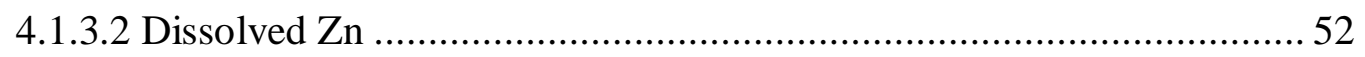

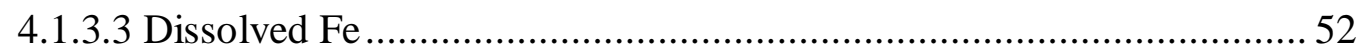

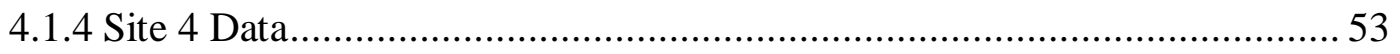

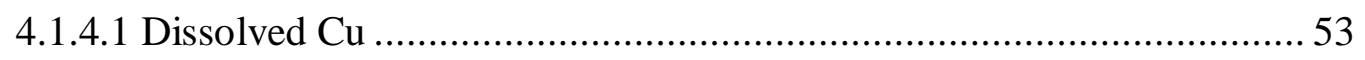

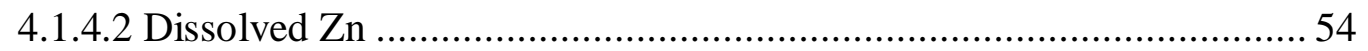

4.1.4.3 Dissolved Fe ............................................................................... 54

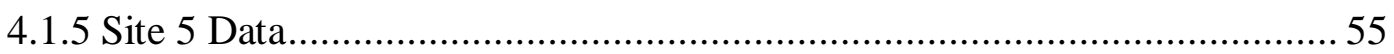

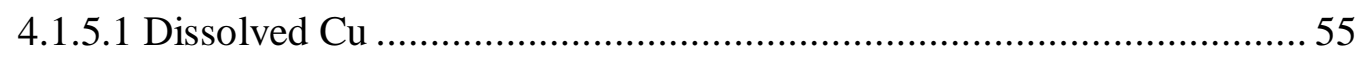

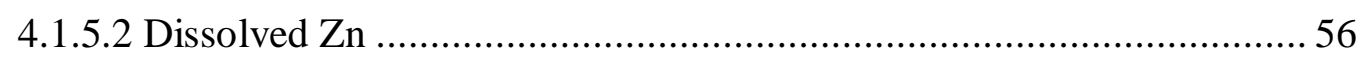

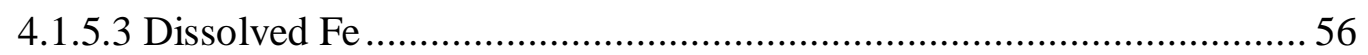

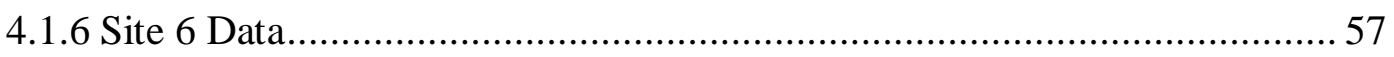

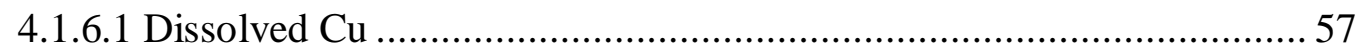

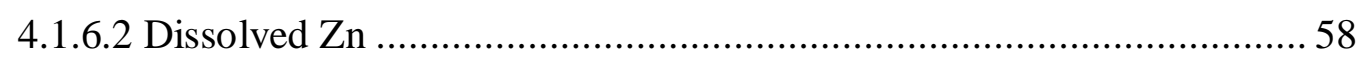

4.1.6.3 Dissolved Fe ............................................................................. 58

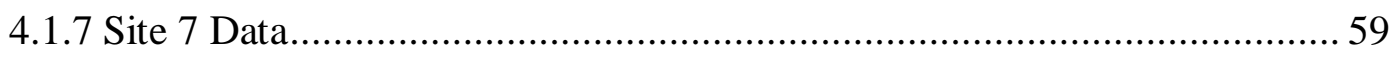

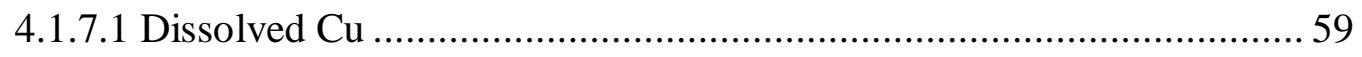

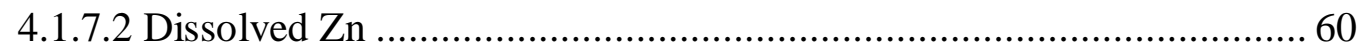

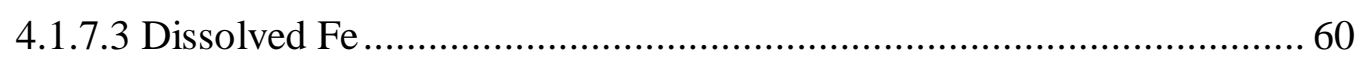

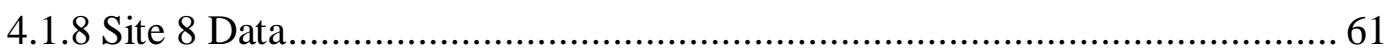




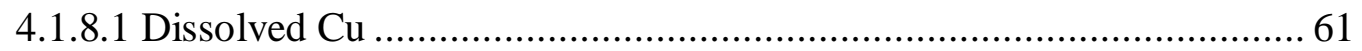

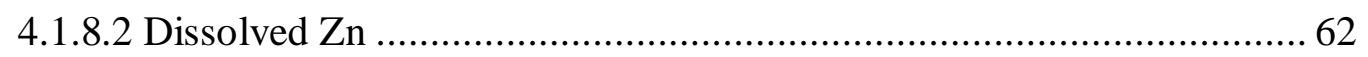

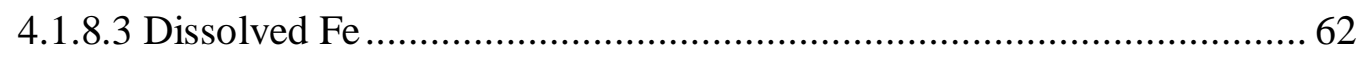

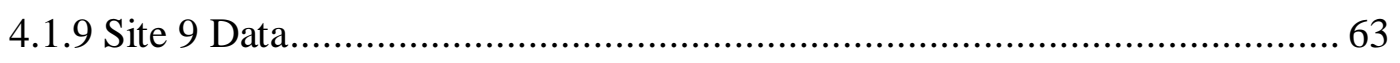

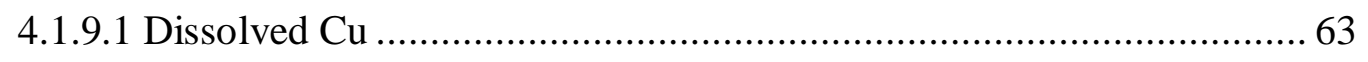

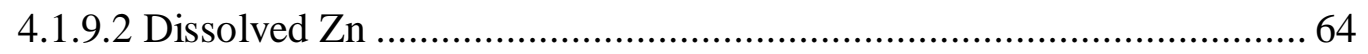

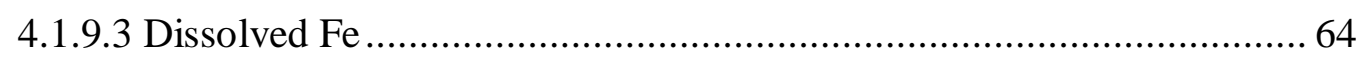

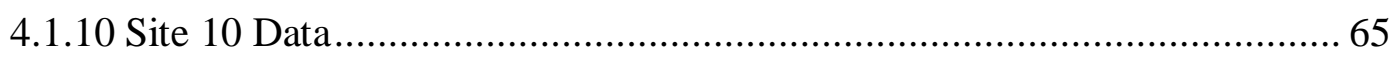

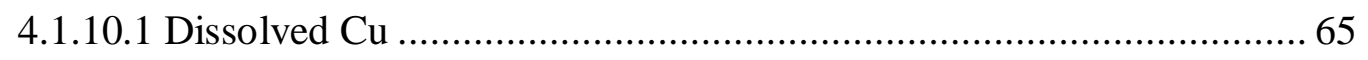

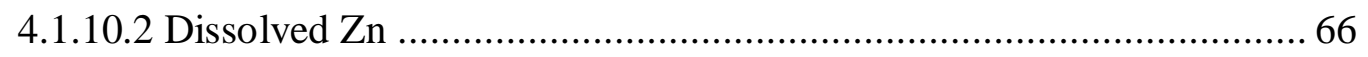

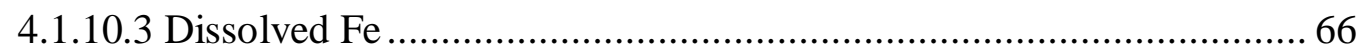

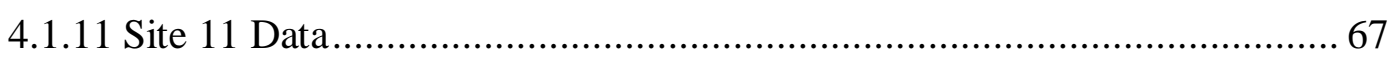

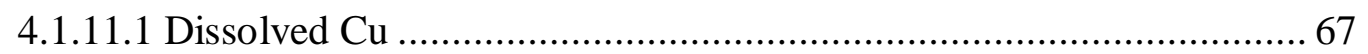

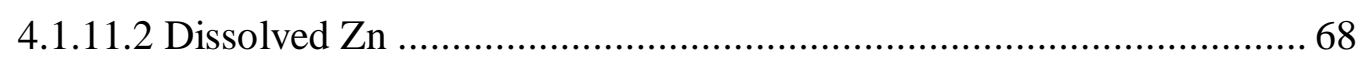

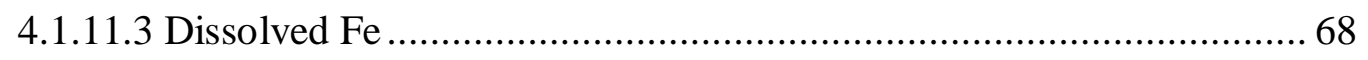

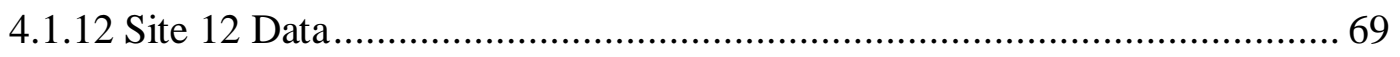

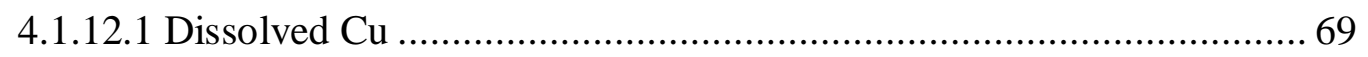

4.1.12.2 Dissolved $\mathrm{Zn}$........................................................................... 70

4.1.12.3 Dissolved Fe ......................................................................... 70

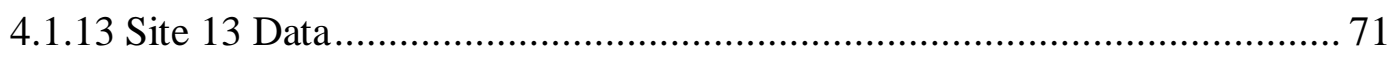

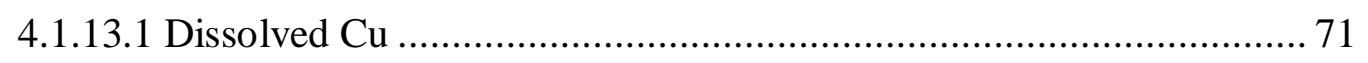

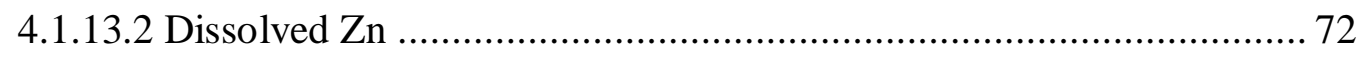

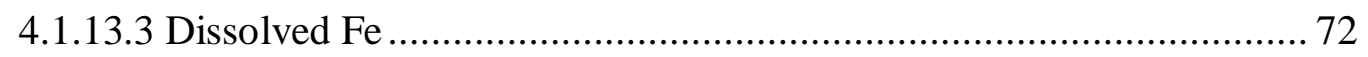

4.2 Discussion of Base Flow and Wet Weather Flow Monitoring Data. ............ 73

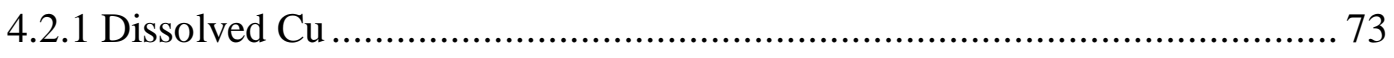

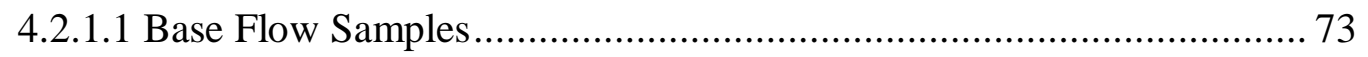

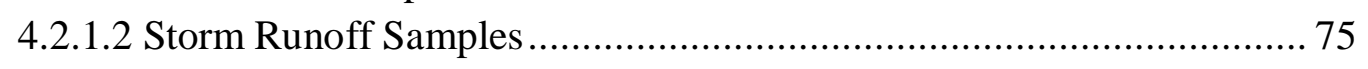

4.2.1.3 First Flush and Composite Samples ................................................ 78

4.2.1.4 Summary of Dissolved $\mathrm{Cu}$ Concentration in Base Flow and Wet

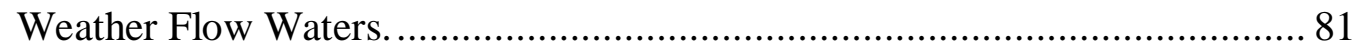

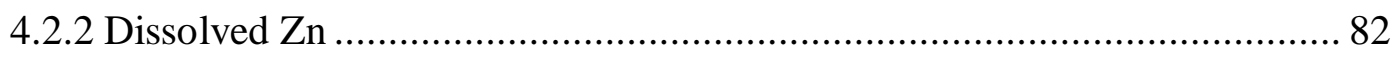

4.2.2.1 Base Flow Samples..................................................................... 82

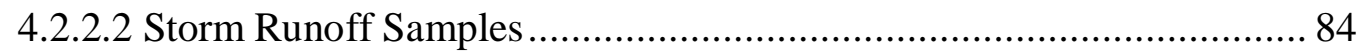

4.2.2.3 First Flush and Composite Samples .............................................. 88

4.2.2.4 Summary of Dissolved Zn Concentrations in Base Flow and Storm

Runoff Monitoring .................................................................................. 90

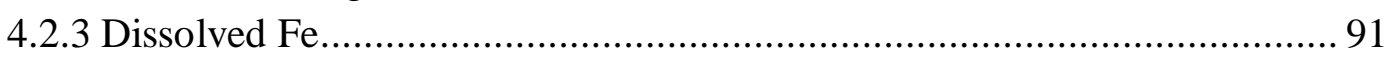

4.2.3.1 Base flow Samples...................................................................... 91

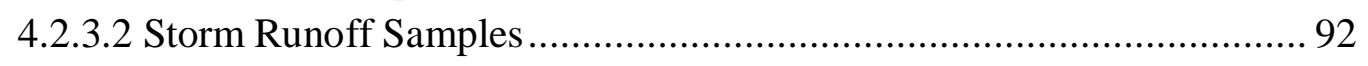

4.2.3.3 First Flush and Composite Samples ............................................... 94

4.2.3.4 Summary of Dissolved Fe Concentrations in Base Flow and Storm

Runoff Monitoring ............................................................................. 95

4.2.4 First Flush of Dissolved Metals and Antecedent Dry Weather .............. 96 
5 INVESTIGATION OF POSSIBLE SOURCES OF DISSOLVED METALS

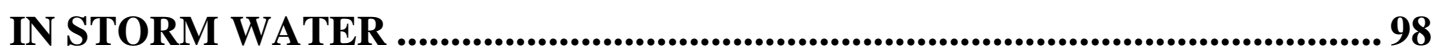

5.1 Atmospheric Rainfall Samples .............................................................98

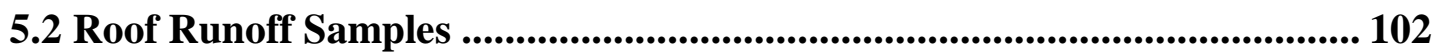

5.3 Paved Surface Runoff Samples...................................................................... 105

6 CONCLUSION AND RECOMMENDATIONS ...................................... 108

REFERENCES ................................. ERROR! BOOKMARK NOT DEFINED.

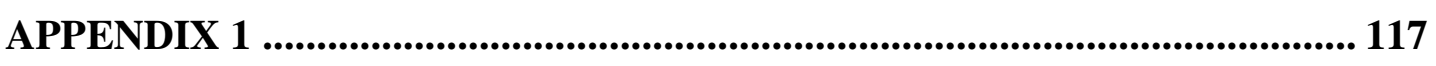

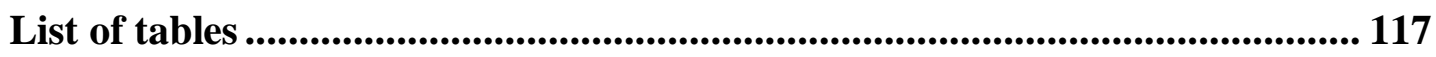

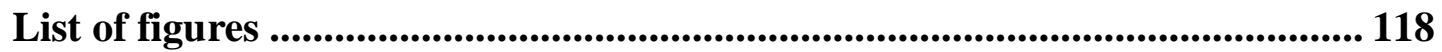

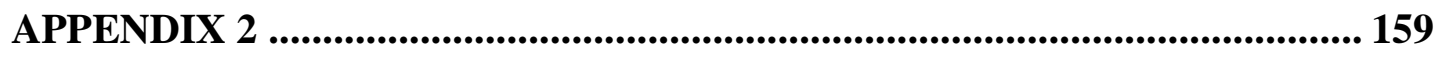

Quality assurance.......................................................................................................... 159

Sites Coordinates ..................................................................................... 165

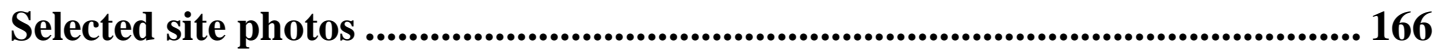




\section{List of Figures}

Figure 1.1 Map of the Wellington region indicating the sampling sites .................. 7

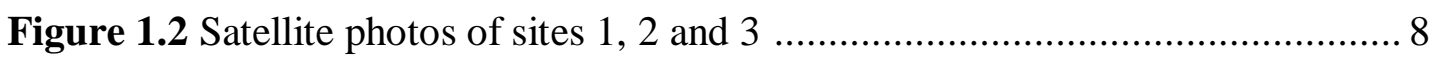

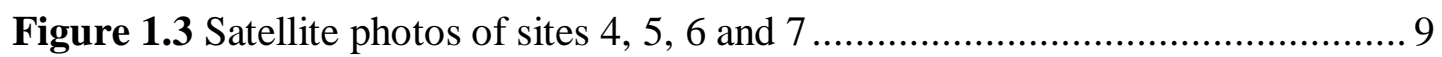

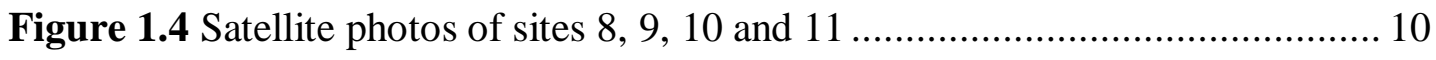

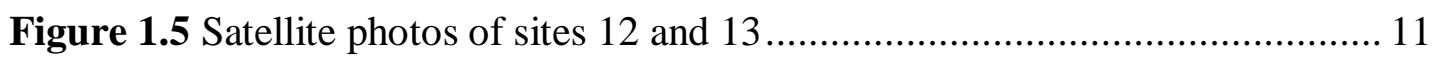

Figure 1.6 Potential sources of heavy metals in urban environment ..................... 12

Figure 2.1 Changing of stream discharge after urbanisation ................................. 16

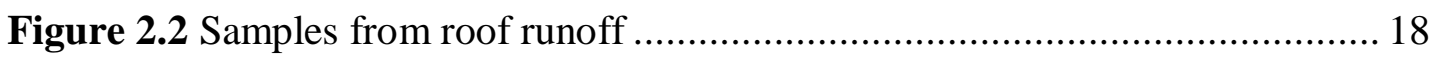

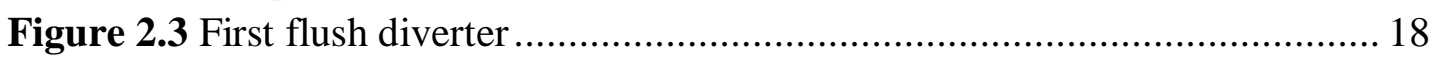

Figure 2.4 Visual observation of storm runoff from a highway in California ........ 19

Figure 2.5 Total mass budgets for zinc in three catchments in Auckland .............. 23

Figure 2.6 Total mass budgets for $\mathrm{Cu}$ in three catchments in Auckland ............... 24

Figure 2.7 Temporal variation of total and dissolved $\mathrm{Cu}$ and $\mathrm{Zn}$ for a storm runoff from a highway in California ............................................................ 25

Figure 2.8 Temporal variation of total and dissolved $\mathrm{Cu}$ and $\mathrm{Zn}$ for a storm runoff from a highway in California .............................................................. 26

Figure 3.1 General sampling protocol for first flush and composite samples by

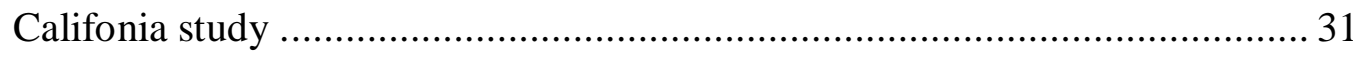

Figure 3.2 General definitions and sampling protocols for first flush and composite

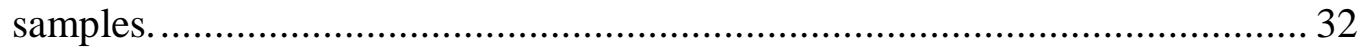

Figure 3.3 Wellington map, sites for the atmospheric rainfall sampling................ 33

Figure 3. 4 Pictures of non-metallic atmospheric rainfall samplers. ..................... 34

Figure 3.5 Schematic of the pre-concentration method. ...................................... 41

Figure 3.6 Stirring stage of water sample in the pre-concentration procedure. ....... 42

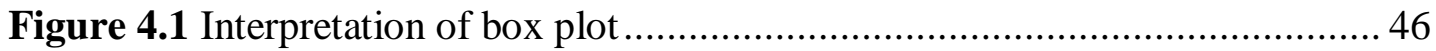

Figure 4.2 Statistical parameters of dissolved $\mathrm{Cu}$ concentrations at site $1 \ldots \ldots \ldots . .47$

Figure 4.3 Statistical parameters of dissolved Zn concentrations at site 1............. 48

Figure 4.4 Statistical parameters of dissolved Fe concentrations at site 1............ 48

Figure 4.5 Statistical parameters of dissolved $\mathrm{Cu}$ concentrations at site 2............ 49

Figure 4.6 Statistical parameters of dissolved $\mathrm{Zn}$ concentrations at site 2 .............50

Figure 4.7 Statistical parameters of dissolved Fe concentrations at site 2 ............ 50

Figure 4.8 Statistical parameters of dissolved $\mathrm{Cu}$ concentrations at sites 3............51

Figure 4.9 Statistical parameters of dissolved $\mathrm{Zn}$ concentrations at sites 3............ 52

Figure 4.10 Statistical parameters of dissolved Fe concentrations at sites 3. ......... 52 
Figure 4.11 Statistical parameters of dissolved $\mathrm{Cu}$ concentrations at site 4. ........53

Figure 4.12 Statistical parameters of dissolved $\mathrm{Zn}$ concentrations at site 4........... 54

Figure 4.13 Statistical parameters of dissolved Fe concentrations at site 4 ........... 54

Figure 4.14 Statistical parameters of dissolved $\mathrm{Cu}$ concentrations at site 5 ...........55

Figure 4.15 Statistical parameters of dissolved $\mathrm{Zn}$ concentrations at site 5............56

Figure 4.16 Statistical parameters of dissolved Fe concentrations at site 5...........56

Figure 4.17 Statistical parameters of dissolved $\mathrm{Cu}$ concentrations at site 6 . ...........57

Figure 4.18 Statistical parameters of dissolved $\mathrm{Zn}$ concentrations at site 6 ............. 58

Figure 4.19 Statistical parameters of dissolved Fe concentrations at site 6............58

Figure 4.20 Statistical parameters of dissolved $\mathrm{Cu}$ concentrations at site 7. .......... 59

Figure 4.21 Statistical parameters of dissolved $\mathrm{Zn}$ concentrations at site 7............ 60

Figure 4.22 Statistical parameters of dissolved Fe concentrations at site 7............60

Figure 4.23 Statistical parameters of dissolved $\mathrm{Cu}$ concentrations at site 8 ......... 61

Figure 4.24 Statistical parameters of dissolved $\mathrm{Zn}$ concentrations at site 8........... 62

Figure 4.25 Statistical parameter of dissolved Fe concentrations at site 8. ............ 62

Figure 4.26 Statistical parameters of dissolved $\mathrm{Cu}$ concentrations at site 9. ...........63 63

Figure 4.27 Statistical parameters of dissolved $\mathrm{Zn}$ concentrations at site 9.............6 64

Figure 4.28 Statistical parameters of dissolved Fe concentrations at site 9............ 64

Figure 4.29 Statistical parameters of dissolved $\mathrm{Cu}$ concentrations at site 10........ 65

Figure 4.30 Statistical parameters of dissolved Zn concentrations at site 10 ......... 66

Figure 4.31 Statistical parameter of dissolved Fe concentrations at site 10............66 66

Figure 4.32 Statistical parameters of dissolved $\mathrm{Cu}$ concentrations at site 11 .........6 67

Figure 4.33 Statistical parameters of dissolved $\mathrm{Zn}$ concentrations at site $11 \ldots \ldots \ldots . . .68$

Figure 4.34 Statistical parameters of dissolved Fe concentrations at site $11 \ldots \ldots \ldots . .68$

Figure 4.35 Statistical parameters of dissolved $\mathrm{Cu}$ concentrations at site 12 ........6 69

Figure 4.36 Statistical parameters of dissolved $\mathrm{Zn}$ concentrations at site $12 \ldots \ldots \ldots . . .70$

Figure 4.37 Statistical parameters of dissolved Fe concentrations at site 12 ......... 70

Figure 4.38 Statistical parameters of dissolved $\mathrm{Cu}$ concentrations at site 13 ........ 71

Figure 4.39 Statistical parameters of dissolved $\mathrm{Cu}$ concentrations at site 13 ........ 72

Figure 4.40 Statistical parameters of dissolved Fe concentrations at site 13......... 72

Figure 4.41 The median values for dissolved $\mathrm{Cu}$ concentrations for sites 1-13...... 74

Figure 4.42 Average of the median values for dissolved $\mathrm{Cu}$ concentrations for suburban residential, commercial, light residential and rural sites ................. 74

Figure 4.43 Summary of dissolved $\mathrm{Cu}$ at 11 different sites within the Wellington

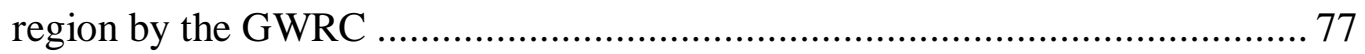

Figure 4.44 The medians of dissolved $\mathrm{Cu}$ concentrations for residential, commercial and idustrial catchments in the Wellington region by the GWRC …............... 77

Figure 4.45 Dissolved Cu concentrations in first flush and composite samples .... 79

Figure 4.46 Summary of dissolved $\mathrm{Cu}$ concentrations in first flush and composite samples by this study and by the GWRC ........................................... 80

Figure 4.47 The median values of dissolved $\mathrm{Zn}$ concentrations for sites 1-13.......82

Figure 4.48 Average of the median values for dissolved $\mathrm{Zn}$ concentrations for suburban residential, commercial, light residential and rural sites. 
Figure 4.49 Summary of dissolved $\mathrm{Zn}$ at 11 different sites within the Wellington region by the GWRC

Figure 4.50 The median of $\mathrm{Zn}$ concentration for residential, commercial and idustrial catchments in the Wellington region by the GWRC......................... 86

Figure 4.51 Dissolved Zn concentrations in first flush and composite samples.. .... 88

Figure 4.52 Summary of dissolved $\mathrm{Zn}$ concentrations in first flush and composite samples by this study and by the GWRC................................................... 89

Figure 4.53 The median values for dissolved Fe concentrations for site 1-13....... 92

Figure 4.54 Average of the median values for dissolved Fe concentrations for suburban residential, commercial, light residential and rural sites.................. 92

Figure 4.55 Dissolved Fe concentrations in first flush and composite samples...... 95

Figure 4.56 Comparison between different antecedent period of dry weather and the concentrations of first flush of heavy metals at site 1 ................................. 97

Figure 4.57 Comparison between different antecedent period of dry weather and the concentrations of first flush of heavy metals at site 8

Figure 5.1 Summary of dissolved $\mathrm{Cu}$ concentrations in the atmospheric rainfall samples collected at VUW.

Figure 5.2 Summary of dissolved $\mathrm{Zn}$ and Fe concentrations in the atmospheric rainfall samples collected at VUW.

Figure 5.3 Summary of dissolved $\mathrm{Cu}$ concentrations in galvanised roof runoff samples.

Figure 5.4 Summary of dissolved $\mathrm{Zn}$ concentrations in galvanised roof runoff samples.

Figure 5.5 Summary of dissolved Fe concentrations in roof runoff samples. 103

Figure 5.6 Summary of dissolved $\mathrm{Cu}$ concentrations in paved surface runoff samples. 106

Figure 5.7 Summary of dissolved $\mathrm{Zn}$ and Fe concentrations in paved surface runoff samples. 106 


\section{List of Tables}

Table1.1 Main characteristics and potential contribution of the monitored sites. ...... 6

Table1.2 ANZECC 2000 toxicity trigger values for $\mathrm{Cu}$ and $\mathrm{Zn}$ at $95 \%$ species protection and the Canadian trigger value for $\mathrm{Fe}$.......................................... 14

Table1.3 Hardness-modified trigger values for chronic $\mathrm{Cu}$ and $\mathrm{Zn}$ toxicity........... 14

Table1.4 Modified USEPA 2006 CMC criteria for dissolved $\mathrm{Cu}$ and $\mathrm{Zn}$............... 15

Table 3. 1 Calculated detection limits for $\mathrm{Cu}, \mathrm{Zn}$ and $\mathrm{Fe}$

Table 3.2 Various reagents and techniques used for pre-concentrating heavy metals in natural waters

Table 3.3 Examination of Chelex-100 recoverability with variables concentrations of $\mathrm{Cu}$ and $\mathrm{Zn}$ concentrations.

Table 3.4 Comparison between the concentrations of dissolved $\mathrm{Cu}, \mathrm{Zn}$ and $\mathrm{Fe}$ obtained from the analysis on FAAS and ICPMS.

Table 4.1 Comparison of dissolved $\mathrm{Cu}$ concentrations in storm water obtained by this study and Rotorua dataset

Table 4.2 Comparison of dissolved $\mathrm{Zn}$ concentrations in storm water obtained by this study and Rotorua dataset.

Table 4.3 Comparison of dissolved Fe concentrations in storm water obtained by this study and Rotorua dataset.

Table 5.1 Dissolved $\mathrm{Cu}, \mathrm{Zn}$ and Fe concentrations in atmospheric rainfall samples at site 13 and the top of MT Victoria tunnel.

Table 5.2 Average of the concentrations of $\mathrm{Cu}, \mathrm{Zn}$ and $\mathrm{Fe}$ in airborne particulate

Table 5.3 Dissolved $\mathrm{Cu}, \mathrm{Zn}$ and $\mathrm{Fe}$ concentrations in first flush and delayed runoff samples collected from galvanised roofs.

Table 5.4 Dissolved $\mathrm{Cu}, \mathrm{Zn}$ and Fe concentrations in samples collected from tile roof runoff. 


\section{Glossary}

ANZECC 2000 TV: Australian and New Zealand Environment and Conservation Council freshwater toxicity trigger values.

Base flow sample: a single grab sample collected manually from the studied sites at weekly bases during dry days.

Chelex-100: polymeric beads consist of polystyrene cross-linked with divinylbenzene and functionalized with iminodiacetate groups as the chelating sites.

CMC: United States Environmental Protection Agency (USEPA 2006) Criteria Maximum Concentrations.

Composite sample: the mathematical mean of the concentrations of dissolved metals in the samples collected after the first flush time.

CTV: Canadian Trigger Value.

FAAS: Flame Atomic Absorption Spectroscopy.

First flush sample: A) in stream water context: the mathematical mean of the concentrations of dissolved metals in the samples collected in the first 25 minutes of the runoff. B) in roof context: a single sample collected at the very early stage of a roof runoff and usually associated with a delayed roof runoff sample.

GWRC: Greater Wellington Regional Council.

ICPMS: Inductively Coupled Plasma Mass Spectrometry.

Mg/L: milligram of the solute per litter of the solution.

SCPS: School of Chemical and Physical Sciences.

Storm runoff sample: a single grab sample collected manually at random times during the runoff, excluding the first flush time from the studied sites.

$\mathbf{P M}_{2.5}$ and $\mathbf{P M} \mathbf{M}_{10}$ : particulate matters with aerodynamic diameters less than 2.5 and $10 \mu \mathrm{m}$ respectively.

VUW: Victoria University of Wellington. 


\section{Chapter 1}

\section{Introduction}

\subsection{Water and Quality}

Water is the most valuable and essential substance on the surface of the planet. There is a direct link between good water quality and health for all known forms of life. However, 'human activity' is responsible for water quality deterioration. In addition, runoff of rain water is well known to play a significant role in lowering water quality by introducing various contaminants to water bodies, including physical and chemical comprising organic and inorganic contaminants. The type and concentration of these contaminants will vary depending upon the environmental characteristics such as natural, pre-urban, urban and industrial areas [1-2].

Heavy metals are one of the most abundant and frequently detected contaminants in natural and storm water in recent years [3-4]. Living organisms require trace amounts of certain heavy metals known as trace metals such as $\mathrm{Cu}, \mathrm{Zn}$ and $\mathrm{Fe}$, to carry out bio-reactions including nerve and oxygen transportation in the organism. In contrast, if the recommended levels are exceeded, the same metals are considered toxic substances producing adverse effects for all living organisms [5].

Over the last decade, a small number of studies have investigated heavy metal contamination in storm water in New Zealand [6], and particularly in the Wellington region [7-8]. This work indicated that heavy metals, particularly dissolved $\mathrm{Cu}$ and Zn concentrations occurred at levels exceeding the recommended chronic and acute toxicity guidelines. 


\subsection{Objectives and Research Questions}

The primary purpose of the present study was to determine the concentrations of dissolved heavy metal, specifically, $\mathrm{Cu}, \mathrm{Zn}$, and $\mathrm{Fe}$ in natural waters during base flow and wet-weather flow at various locations throughout the Wellington region. The secondary objective was to examine possible sources of $\mathrm{Cu}, \mathrm{Zn}$ and $\mathrm{Fe}$ present in storm water during rainfall events.

Research Questions:

1) What are the concentrations of dissolved $\mathrm{Cu}, \mathrm{Zn}$ and $\mathrm{Fe}$ in Wellington streams?

2) How do the concentrations compare with the recommended chronic toxicity guidelines?

3) What are the concentrations of dissolved $\mathrm{Cu}, \mathrm{Zn}$, and $\mathrm{Fe}$ during the runoff events?

4) How do the concentrations of $\mathrm{Cu}, \mathrm{Zn}$ and $\mathrm{Fe}$ during the runoff events compare with the recommended chronic and acute toxicity triggers, and to the base flow levels?

5) What are the possible sources of dissolved metals, $\mathrm{Cu}, \mathrm{Zn}$ and $\mathrm{Fe}$, in storm water during rainfall events? 


\subsection{Research Approach}

In order to answer the first two questions a weekly monitoring program was carried out at seven sites on three urban streams between January and July in 2011. In March, six additional sites on three additional streams were included in the program to obtain detailed information regarding residential and rural sites (sites 8-13). The outcome of the monitoring program (base flow dataset) was utilized to assess base flow water quality from a dissolved $\mathrm{Cu}, \mathrm{Zn}$ and $\mathrm{Fe}$ concentration perspective and to establish background concentrations. The base flow dataset helps one to understand the impact of storm water runoff on dissolved $\mathrm{Cu}, \mathrm{Zn}$ and $\mathrm{Fe}$ concentrations present in the receiving water bodies.

Questions 3 and 4 were answered in two ways: first, collecting a single sample during several runoff events at each site to provide a dataset (so-called storm runoff samples) in parallel to base flow data set; second, continuous monitoring of storm runoff to examine first flush phenomenon (discussed in chapter 2), which potentially carries higher concentrations of dissolved $\mathrm{Fe}, \mathrm{Cu}$ and $\mathrm{Zn}$.

Question 5 was resolved by collecting and analysing three different types of sample:

A) Atmospheric rainfall samples, at three main collection sites: 1) VUW campus, 2) a rural site (site 13), and 3) a site with high traffic volumes (Mt Victoria tunnel).

B) Roof runoff samples: Runoff from two roof types (galvanised and tile) were examined. The selected roofs were located in Wellington City, Porirua, Tawa, and Karori.

C) Storm water runoff from paved surfaces: Run off from road surfaces and parking areas has been collected and analysed to measure the concentration of dissolved $\mathrm{Fe}, \mathrm{Cu}$ and $\mathrm{Zn}$. The studied paved surfaces were either close to VUW campus or adjacent to one of the monitored sites. 


\subsection{Study Area and Sites Classifications}

The monitored sites are located within the Wellington region and represent six streams, having different physical characteristics.

A total of four sites were located on the Porirua Stream, sites 1-4. Porirua stream is classified as an urban stream and is one of the most important streams in the Wellington region. It runs from Johnsonville (residential area), passing through Tawa with residential, light industrial and commercial activity, to Porirua Harbour and drains a total area of more than 3567 hectares. Porirua stream receives storm water from a motorway and a railway for almost all of its length [21]. The lowest water flow is experienced at the zone adjacent to Johnsonville (site 1) and the flow gradually increases, due to mixing with other tributaries, to reach its maximum before entering Porirua Harbour (site 4, 200 meters upstream from Porirua Harbour).

Kenepuru Stream drains a total area of about 1299 hectares and it also drains into Porirua Harbour [21] (site 5 is located 200 meters upstream from the Porirua Harbour). Kenepuru Stream passes through a residential area on the eastern side of Porirua.

Takapu Stream is divided into two regions. The upper reaches of Takapu Stream pass through farm lands, natural bush and unmodified areas (site 6 is located at the end of this zone). The lower reaches of Takapu Stream pass through a commercial area (site 7) before crossing State Highway 1 and before entering Porirua Stream.

Karori Stream is one of the important streams in the Wellington region. It drains a total area of 3093 hectares and is divided into two zones. The upper portion of Karori Stream is extensively modified, piped in concrete channels, while passing through the residential area of Karori and its associated commercial activities, [21], (where site 8 is located). The lower reaches of this stream have light residential activities and light land modifications [21] (site10). Site 9 is located in a tributary of Karori Stream which passes through a light residential zone before entering Karori Stream. 
Makara and Ohariu Streams are mostly classified as rural. They drain total areas of 6117 and 1804 hectares respectively and drain into Opau Bay [21]. Sites 11 and 12 are located on Makara Stream, separated by about 4 kilometres. Site 13 is located on Ohariu Stream, which flows into the Makara Stream downstream after site 12.

The monitored sites were adjacent to roads, varying in traffic density, and had single dominant land-uses. To facilitate comparison between sampling sites, all sites were classified under four categories, suburban residential (sites 1, 5, 8), commercial (sites $3,4,7)$ light residential (sites 2, 9 and 11) and rural (sites 6, 11, 12 and 13). With this division, one can evaluate the contaminants of concern and predict the sources of these contaminants. Table 1.1 illustrates characteristics of the monitored sites. Figure 1.1 shows a map of the Wellington region and the location of the monitored sites. Figures 1.2, 1.3, 1.4, and 1.5, [9], show satellite photos of the monitored sites and illustrate the nature of surrounding terrain. Additionally, site coordinates and selected pictures of the monitored sites are in Appendix 2. 
Table 1.1 Main characteristics of the monitored sites.

\begin{tabular}{|c|c|c|}
\hline $\begin{array}{c}\text { Site } \\
\text { number }\end{array}$ & Site name & $\begin{array}{c}\text { Main characteristics of surrounding } \\
\text { terrain }\end{array}$ \\
\hline 1 & Wingfield Place, Porirua Stream & Suburban residential. \\
\hline 2 & $\begin{array}{l}\text { Middleton Road Tunnel, } \\
\text { Glenside, Porirua Stream }\end{array}$ & Light residential. \\
\hline 3 & $\begin{array}{c}\text { Tawa, Main Road, Porirua } \\
\text { Stream. }\end{array}$ & Commercial zone. \\
\hline 4 & $\begin{array}{l}\text { Kenepuru Drive, next to the flow } \\
\text { monitoring station, Porirua } \\
\text { Stream. }\end{array}$ & Commercial zone. \\
\hline 5 & $\begin{array}{c}\text { Champion Street, Kenpuru } \\
\text { Stream }\end{array}$ & Suburban residential. \\
\hline 6 & $\begin{array}{c}\text { Woodburn Drive- Takapu Road, } \\
\text { Takapu Stream }\end{array}$ & Rural area. \\
\hline 7 & Takapu Road, Takapu Stream & Commercial zone. \\
\hline 8 & $\begin{array}{c}\text { Karori Park eastern, Karori } \\
\text { Stream }\end{array}$ & Suburban residential \\
\hline 9 & $\begin{array}{c}\text { Karori Park western, a tributary } \\
\text { of Karori Stream. }\end{array}$ & Light residential. \\
\hline 10 & $\begin{array}{c}\text { Makara Peak, Mountain Bike } \\
\text { Park, Karori Stream. }\end{array}$ & Light residential. \\
\hline 11 & Makara Road, Makara Stream. & Rural area. \\
\hline 12 & $\begin{array}{c}\text { Takarau Gorge Road, Makara } \\
\text { Stream. }\end{array}$ & Rural area. \\
\hline 13 & $\begin{array}{c}\text { Takarau Gorge Road, Ohariu } \\
\text { Stream. }\end{array}$ & Rural area. \\
\hline
\end{tabular}




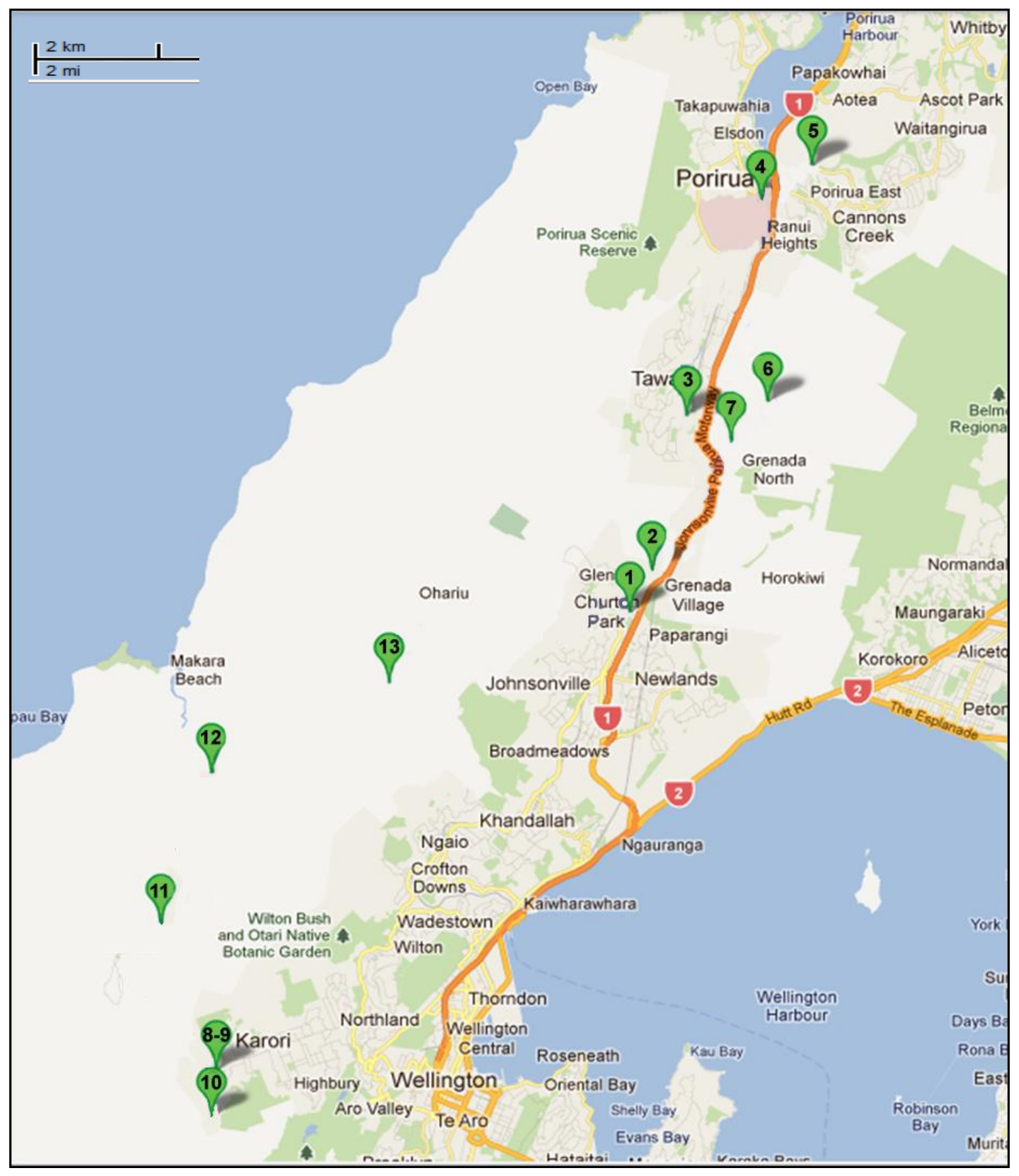

Figure 1.1 Map of the Wellington region indicating the sampling sites [39]. 

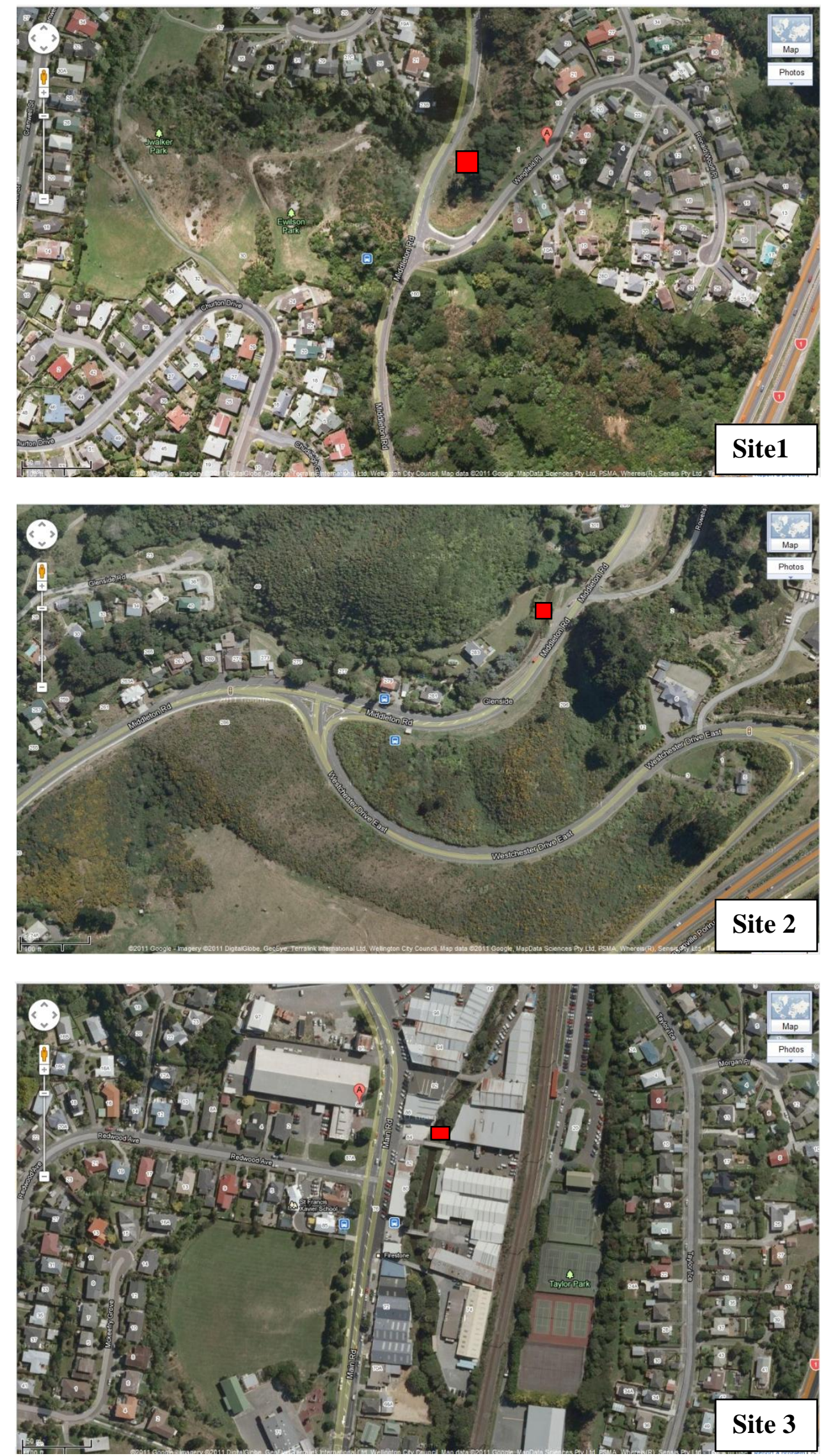

Figure 1.2 Satellite photos of sites 1, 2 and 3 (the red marks). 

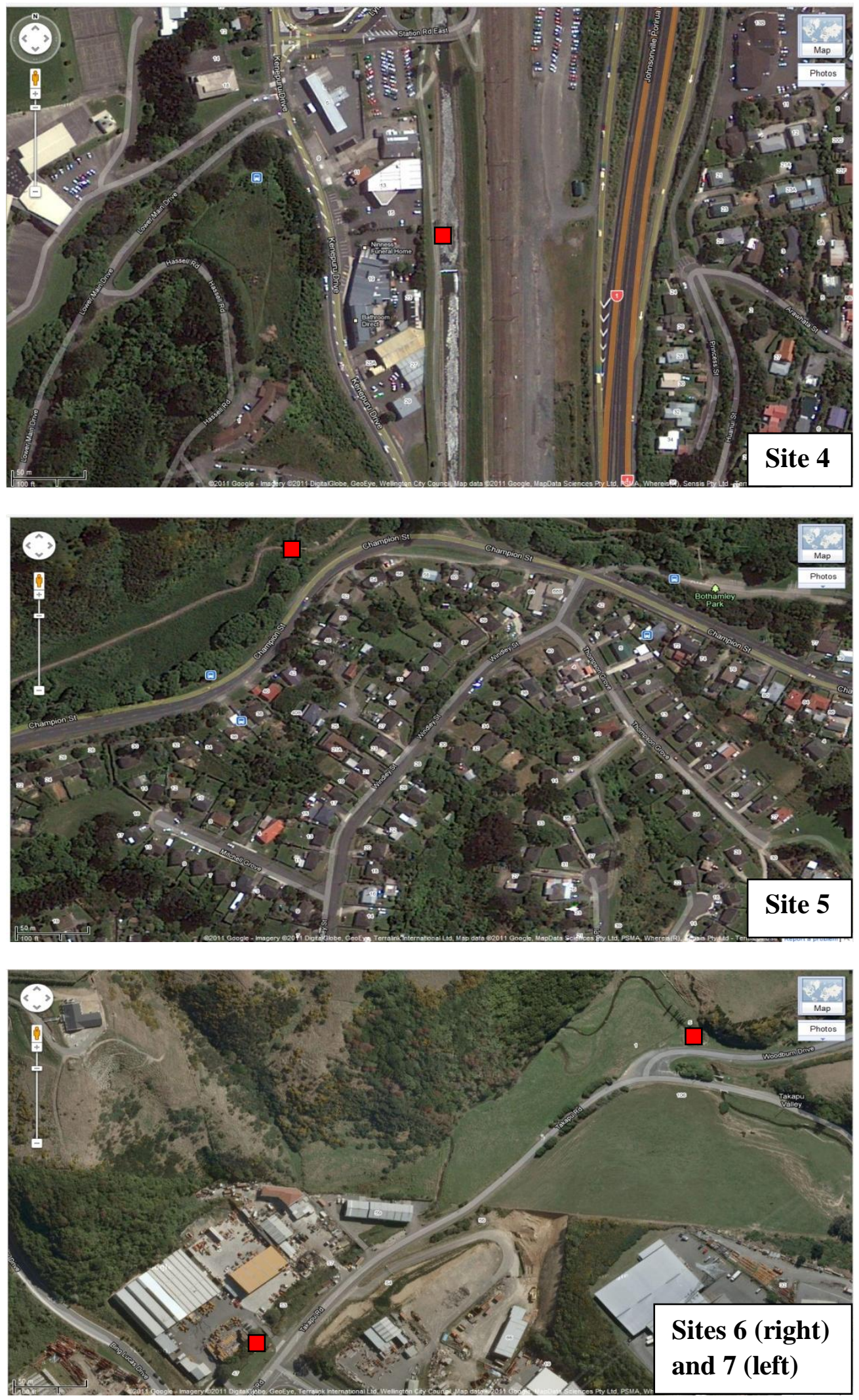

Figure 1.3 Satellite photos of sites 4, 5, 6 and 7 (the red marks). 

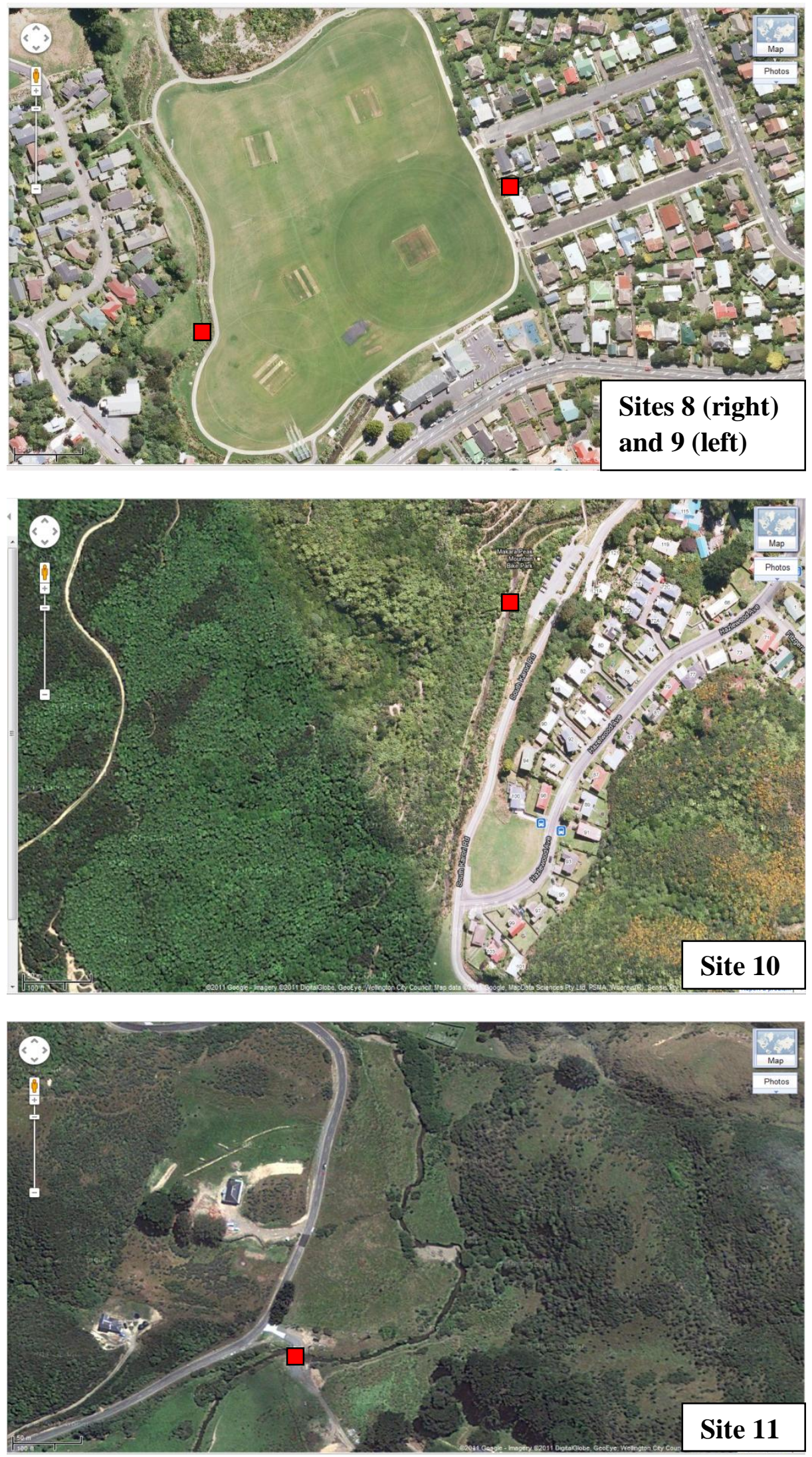

Figure 1.4 Satellite photos of sites 8, 9, 10 and 11 (the red marks). 

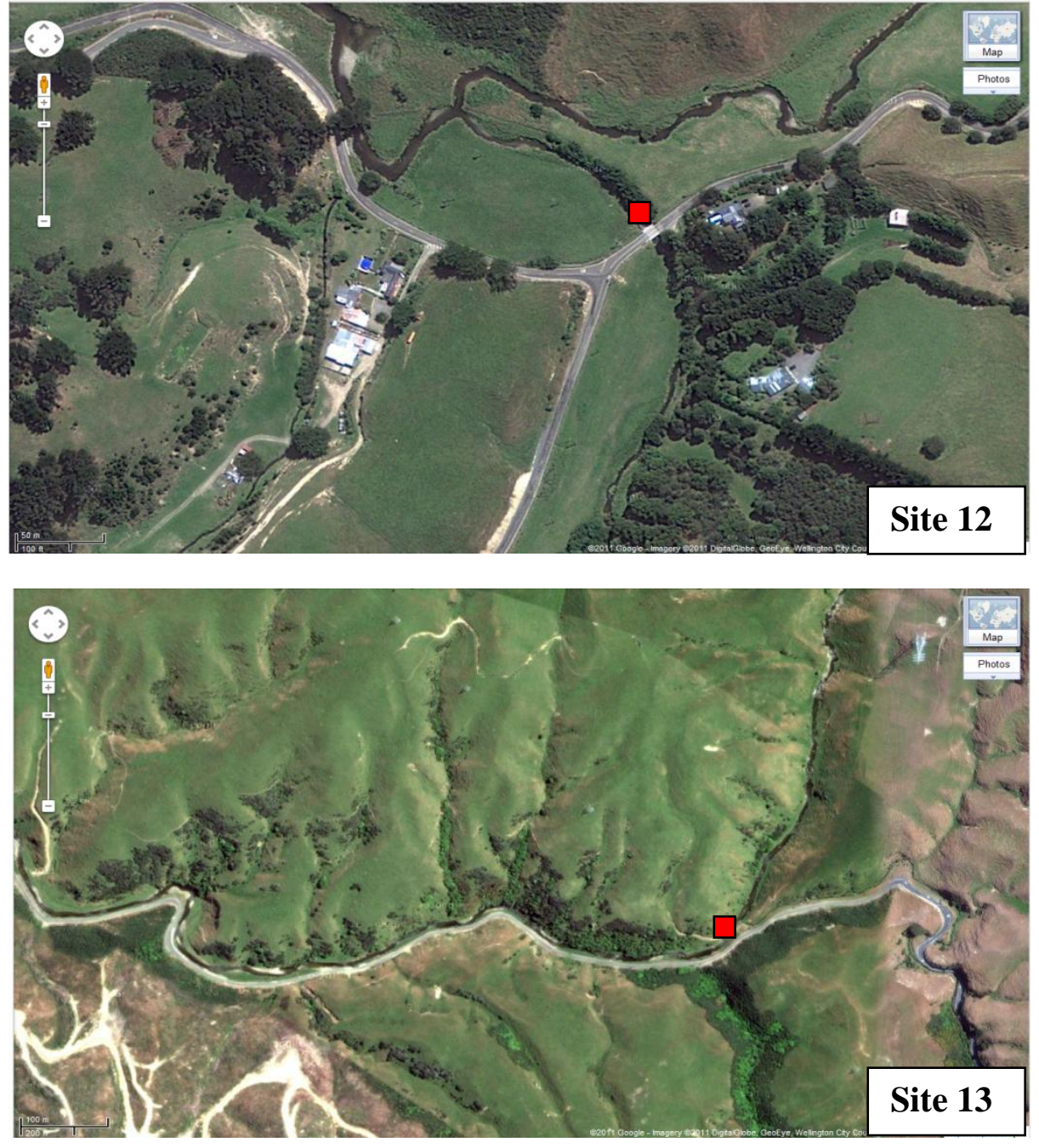

Figure 1.5 Satellite photos of sites 12 and 13 (the red marks) 


\subsection{Heavy Metals in Natural and Storm Waters: Sources and Effects}

Non-point sources of pollution (diffuse sources) have been identified as the major cause of increasing trace metal concentrations, specifically, $\mathrm{Cu}, \mathrm{Zn}$ and $\mathrm{Fe}$, within urban watersheds. There is increasing recognition that diffuse sources may contribute to the emission of $\mathrm{Cu}, \mathrm{Zn}$ and $\mathrm{Fe}$ during storm runoff by producing particulate materials constituted of these metals or by producing these metals directly as a result of corrosion. Sources such as road components, wear and tear of tyre components and engine parts, brake pads and the dust generated by their use, rusting process of auto bodies, infrastructure and building components, including materials containing metals such as galvanised roofs, intensive traffic and fuel combustion are considered to be the major causes of water quality degradation during runoff events [10-17]. Figure 1.6 illustrates examples of potential sources of heavy metals, $\mathrm{Cu}, \mathrm{Zn}$, and $\mathrm{Fe}[10]$.

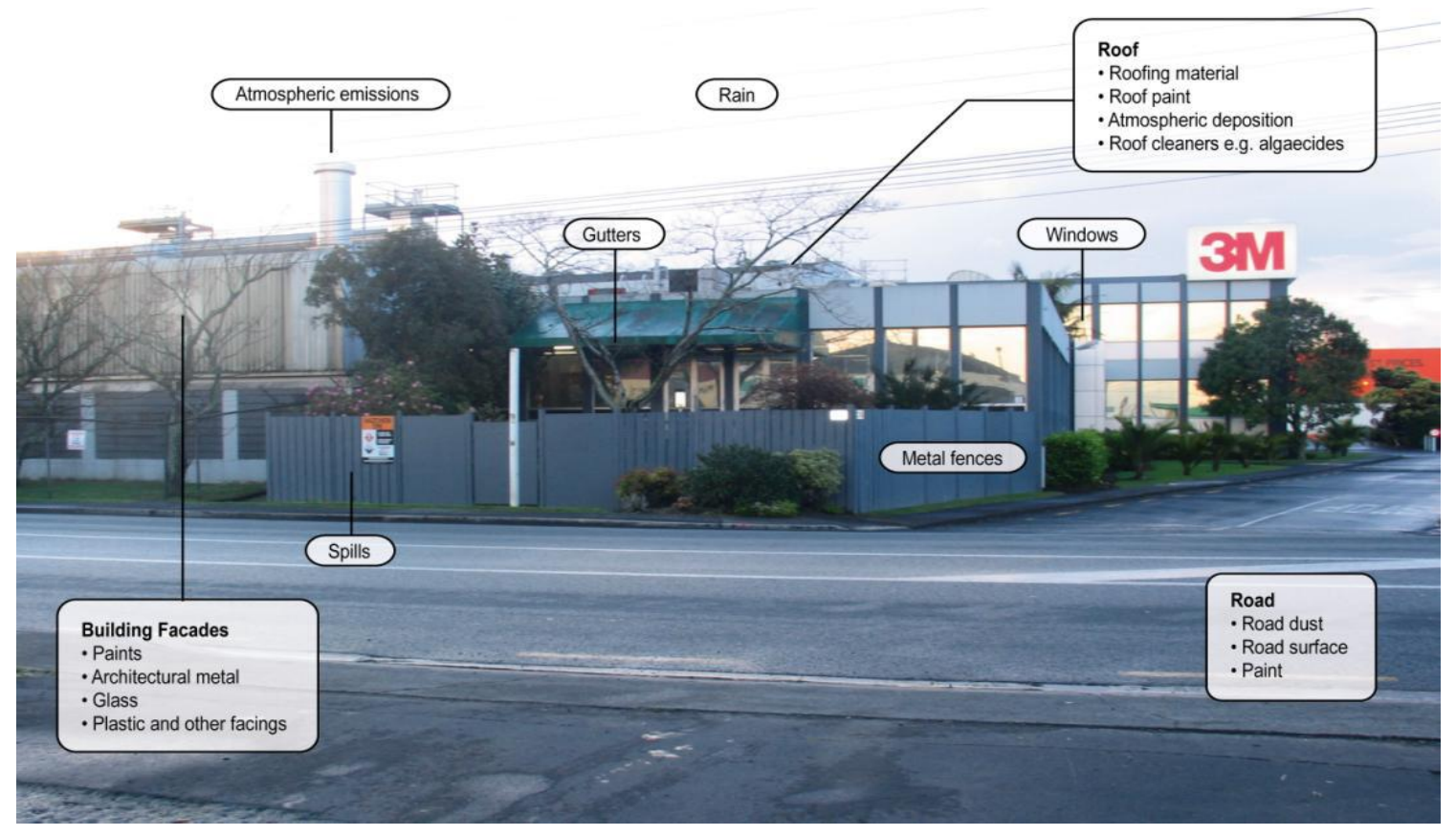

Figure 1.6 Potential sources of heavy metals in urban environment, obtained from [10]. 
The principal concern regarding the potential adverse effects of heavy metals is that the long term uptake by sediment leads to sediment toxicity and bioaccumulation of heavy metals in the resident aquatic life [5-6, 18]. Metals exist in either dissolved (dissolved refers to the concentration of metal obtained by filtering the sample through a $0.45 \mu \mathrm{m}$ membrane) or solid form. Metals are persistent and accumulate in filter feeding animals such as shell fish, so elevated concentrations could pose public health issues. Natural aquatic ecosystems may become contaminated and could be adversely effected by heavy metals released from human activities, and this may have disturbing effects on the ecological balance and diversity of aquatic organisms residing in the receiving watershed environment [5]. Dissolved metals are the most bio-available fraction and therefore should be used to assess the potential toxicity and natural waters quality [11].

\subsection{The Guidelines}

The Australian and New Zealand Environment and Conservation Council freshwater toxicity trigger values (ANZECC 2000 TV) for heavy metals are intended to provide protection from sustained exposure and are derived from chronic toxicity field tests on multiple species. The ANZECC (2000) toxicity guidelines provide four data sets of protection levels. The commonly applied level to slightly to moderately disturbed aquatic ecosystems is the $95 \%$ protection level [11], which in this study was used to interpret base flow and wet-weather data. The toxicity of metals in water depend on the water's hardness, but published toxicity trigger values are only presented for a default hardness value of $30 \mathrm{mg} / \mathrm{L}$ as $\mathrm{CaCO}_{3}$. ANZECC presented a mathematical expression, represented in eq. 1.1, that allows the modification of the trigger value to the new measured hardness. One can calculate a hardness-modified trigger value (HMTV) for $\mathrm{Cu}$ and $\mathrm{Zn}$ from the previously published ANZECC trigger values for any hardness value.

Hardness modified trigger value for $\mathrm{Cu}$ and $\mathrm{Zn}=$ Trigger value $\mathrm{X}$ (Measured hardness $/ 30)^{0.85}$ 
It is important to note that ANZECC 2000 toxicity trigger values are not considered to be a pass or fail criteria. In fact, developers of these guidelines emphasise that they are only one of several evidences that will help in judging the potential effects of metal contaminants on a given environment [4, 8, 11, 19]. Table 1.2 and Table 1.3 show unmodified and hardness modified ANZECC (2000) toxicity trigger values for $\mathrm{Cu}$ and $\mathrm{Zn}$ at $95 \%$ species protection. ANZECC noted that there was not enough information to derive a reliable trigger value for $\mathrm{Fe}$, so the Canadian trigger value (CTV) is recommended and was used in this work.

Table 1.2 ANZECC 2000 toxicity trigger values for $\mathrm{Cu}$ and $\mathrm{Zn}$ at $95 \%$ species protection and the Canadian trigger value for $\mathrm{Fe}[11]$.

\begin{tabular}{|c|c|}
\hline Metal & $\begin{array}{c}\text { ANZECC toxicity } \\
\text { trigger values and } \\
\text { CTV } \\
{[\mathrm{mg} / \mathrm{L}]}\end{array}$ \\
\hline $\mathrm{Cu}$ & 0.0014 \\
\hline $\mathrm{Zn}$ & 0.008 \\
\hline $\mathrm{Fe}$ & 0.3 \\
\hline
\end{tabular}

Table 1.3 Hardness-modified trigger values for chronic $\mathrm{Cu}$ and $\mathrm{Zn}$ toxicity.

\begin{tabular}{ccc}
\hline Stream name & $\begin{array}{c}\text { Dissolved Cu HMTV } \\
{[\mathbf{m g} / \mathbf{L}]}\end{array}$ & $\begin{array}{c}\text { Dissolved Zn HMTV } \\
{[\mathrm{mg} / \mathbf{L}]}\end{array}$ \\
\hline Porirua Stream & 0.00183 & 0.01043 \\
Karori Stream & 0.00152 & 0.00868 \\
Makara Stream & 0.00171 & 0.01000 \\
Ohariu Stream & 0.00171 & 0.01000 \\
Kenepuru and & No hardness information is available. \\
Takapu Streams & & \\
\hline
\end{tabular}

Calculations in Table 1.3 are based on hardness information provided by the Greater Wellington Regional Council (GWRC) [20].

\footnotetext{
${ }^{1}$ A report by the GWRC [7] showed that the value of Ohariu stream water hardness is comparable to Makara stream.
} 
As previously noted, ANZECC 2000 toxicity trigger values are intended for protection from sustained exposure and the exposure to storm water derived dissolved $\mathrm{Cu}, \mathrm{Zn}$ and $\mathrm{Fe}$ is comparably short, therefore, storm runoff data was additionally compared against the United States Environmental Protection Agency (USEPA 2006) Criteria Maximum Concentrations (CMC). CMC values are higher than the ANZECC toxicity trigger values and established maximum protection numbers that do not cause adverse effects on the exposed aquatic population as a result of brief exposure (acute toxicity) to dissolve heavy metals [8].

Table 1.4 Modified USEPA 2006 CMC criteria for dissolved $\mathrm{Cu}$ and $\mathrm{Zn}$ [8].

\begin{tabular}{lc}
\hline Metal & $\begin{array}{c}\text { Modified USEPA 2006 CMC criteria } \\
{[\mathrm{mg} / \mathrm{L}]}\end{array}$ \\
\hline $\mathrm{Cu}$ & 0.006 \\
$\mathrm{Zn}$ & 0.0568 \\
$\mathrm{Fe}$ & No data available \\
\hline
\end{tabular}

In Table 1.4, the original values were derived at a hardness of $100 \mathrm{mg} / \mathrm{L}$ as $\mathrm{CaCO}_{3}$, and the current numbers were adjusted to meet local water hardness in the range of 0 to $52 \mathrm{mg} / \mathrm{L}$ as $\mathrm{CaCO}_{3}[8]$. 


\section{Chapter 2}

\section{Scope of First Flush and Literature Review}

\subsection{First Flush Phenomenon}

The following questions are addressed below:
A) What is first flush?
B) What are the factors effecting the quality of first flush?
C) Where and how to use first flush gathered information?

Urbanization facilitates the rapid transport of storm water runoff to the nearest watershed $[3,17]$. Figure 2.1 shows the relationship between the peak value of water hydrology and a comparison between the speed of water transport in urbanized and pre-urban environments. Urbanization storm runoff peaks occur at shorter times in comparison to pre-urban storm water runoff [21].

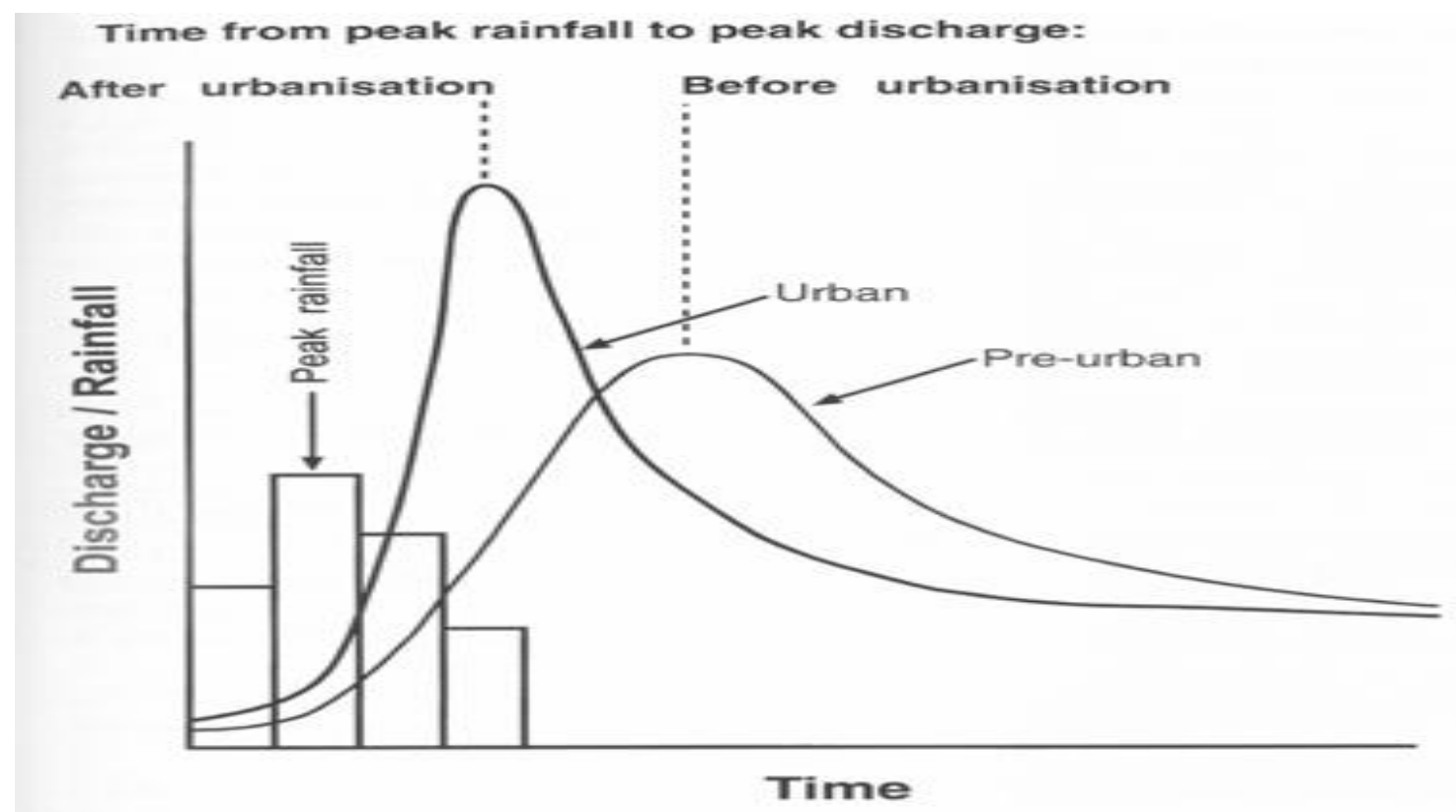

Figure 2.1 Changing of stream discharge after urbanisation, obtained from [21]. 
As rainwater travels over natural and manmade surfaces, it washes the accumulated contaminants off and corrodes surface components. The largest flux of contamination and the most contaminated portion of runoff in urban watersheds is likely to come with the first volume of the runoff event, this phenomenon is known as the first flush [22-28]. First flush is a phenomenon associated with any storm water contaminant variables, for instance first flush of (heavy metals), first flush of $(\mathrm{pH})$ or first flush of (turbidity) [29]. Moreover, several factors affect the quality and the existence of first flush in a given area [27, 29].

1) Climate characteristics, the length of antecedent dry weather.

2) Rainfall characteristics, the intensity of rainfall.

3) Runoff quantity characteristic, the volume of the runoff.

4) Characteristics of the catchment (imperviousness of the area as such) in relation to receiving water body.

First flush phenomena have been utilized for 1) the prediction of contamination levels in rain water collected by harvesting systems, [30], and 2) the potential adverse impact on the receiving environments [8].

Firstly, rain water harvesting systems are a common method used to supply water for domestic purposes in many countries such as New Zealand and Australia [31-32]. The quality of potable water collected by this method has to meet the recommended guidelines [33]. Engineering solutions are employed to divert the contaminated first flush of the rain [23]. Figure 2.2 shows a series of samples collected from roof runoff. The analysis of first flush sample indicated high turbidity and conductivity in relation to later runoff samples [23]. The majority of the engineering solutions are based on the elimination of the initial volume of rain water runoff $[23,26,30]$. Figure 2.3 shows an example of a first flush diverter, the mechanical operation is based on elimination of the first contaminated volume of rainwater runoff from roofs [23]. 


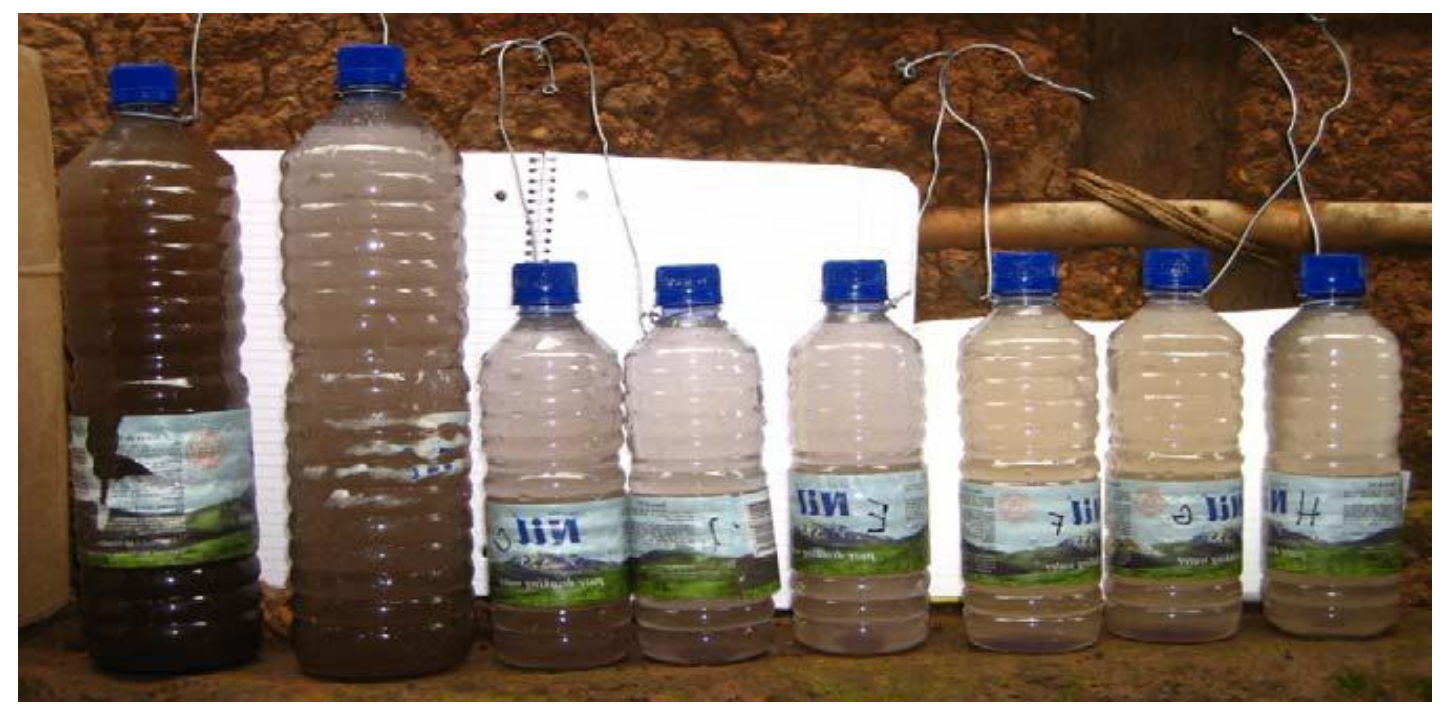

Figure 2.2 Samples, left to right, collected subsequently, earlier to later, from roof runoff, obtained from [23].
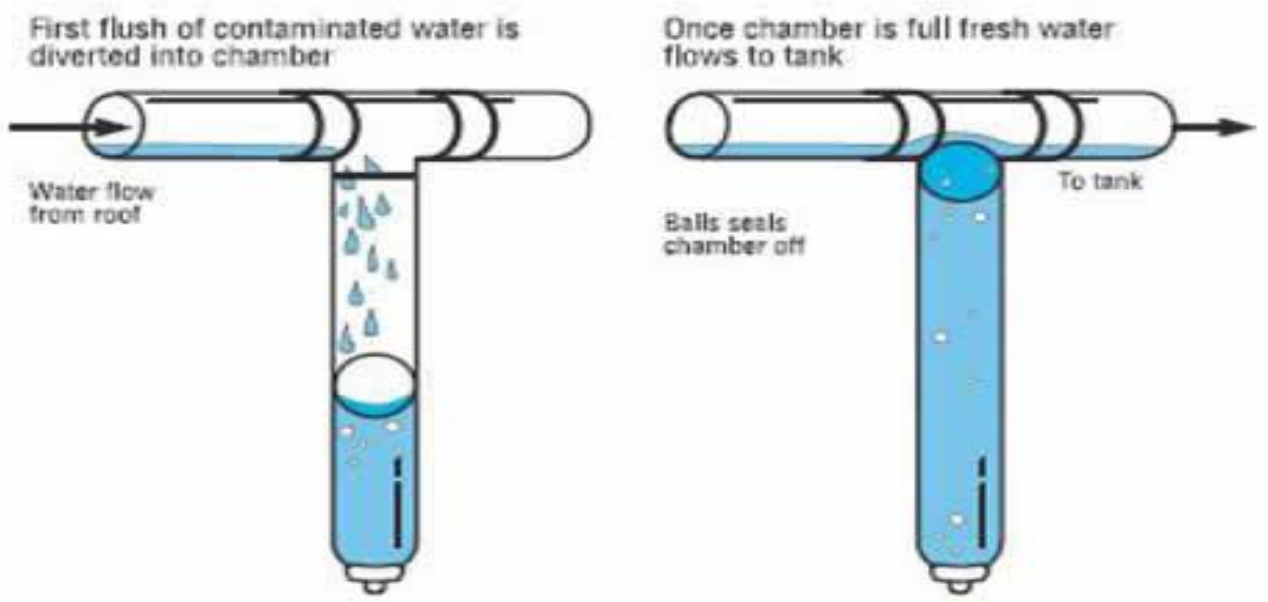

Figure 2.3 First flush diverter which consists of a chamber with a floating ball which isolates the contaminated portion of roof runoff, obtained from [23]. 
Secondly, first flush has been used for water pollution control and is monitored as an indicator of environmental pollution and associated hazards [8, 29]. In most cases, the concentrations of water variables (physical and chemical, organic and inorganic contaminants) are higher during the first stage of runoff and lower at later stages. This suggests that treating the first portion of storm water, rather than treating all storm runoff, drops the contamination level sharply, and could be cost effective, as shown in Figure 2.4 [29]. Figure 2.4 displays visual observation (turbidity) of storm runoff, monitored in California, wherein the storm water becomes less contaminated as the storm progresses [29].

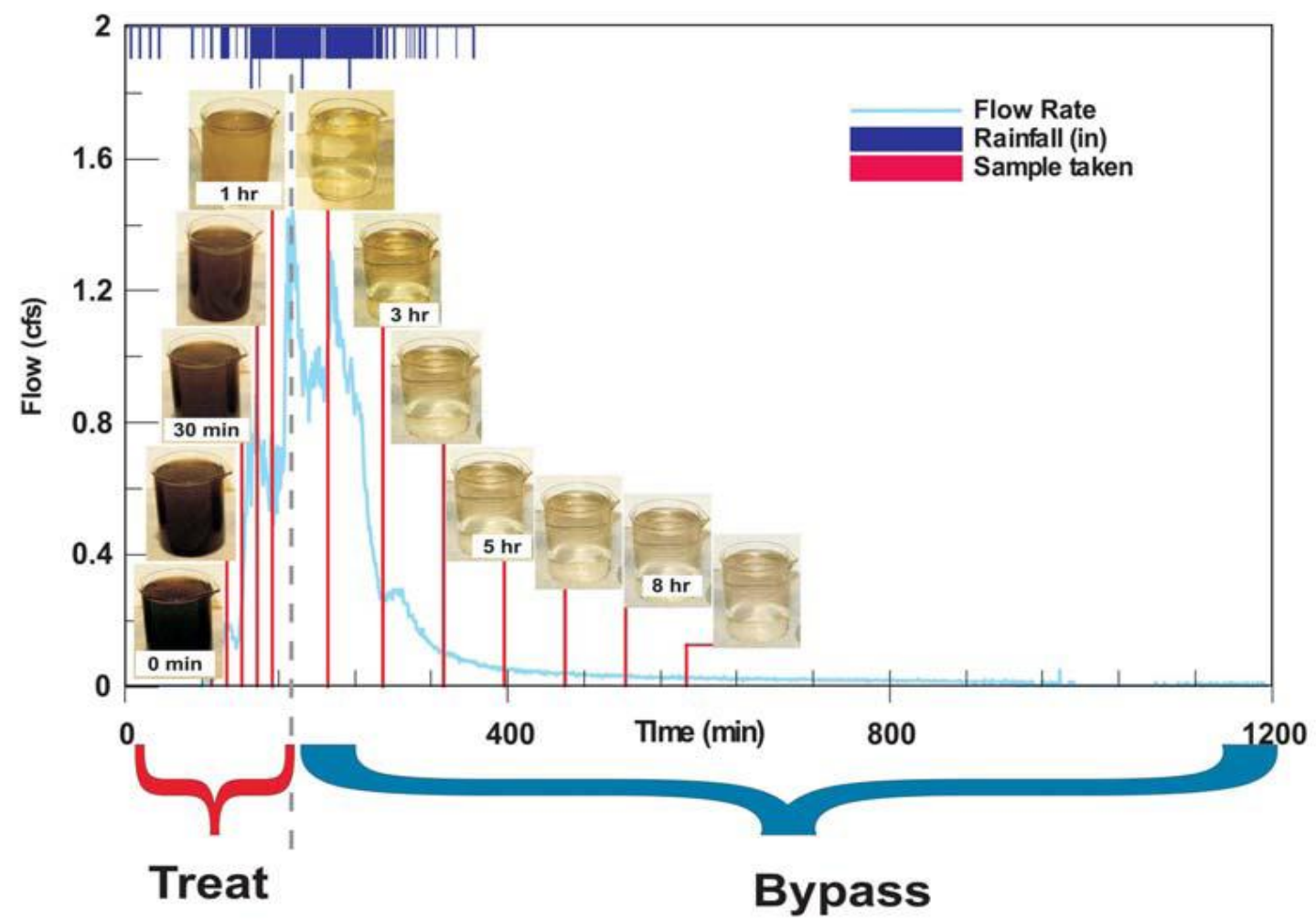

Figure 2.4 Visual observation of monitoring urban storm runoff from a highway in California, obtained from [29]. 


\subsection{Literature Review}

As previously mentioned, urban storm runoff discharges introduce various contaminants to the columns of water. There were a limited number of studies found in the literature investigating heavy metals in New Zealand streams. This subchapter provides a discussion of the available New Zealand studies and some examples of international work.

\subsubsection{Wellington Region}

Before reviewing the literature in storm water, it should be noted that $\mathrm{Cu}$ and $\mathrm{Zn}$, which are known contaminants in urban streams, and Fe were incorporated into the regular monthly baseline monitoring program undertaken by the GWRC in 2008. A recent report by the GWRC [4], shows the results of 2009- 2010 annual monitoring at sites across the Wellington region. According to this study, the median values for the concentrations of dissolved $\mathrm{Cu}$ and $\mathrm{Zn}$ exceeded their respective ANZCC (2000) $\mathrm{TV}$ at 3 and 4 urban sites respectively. However, if the previous guidelines were modified to take into account local water hardness, only the median values of dissolved $\mathrm{Zn}$ concentrations exceeded the HMTV at 3 sites; the Porirua Stream at Wall Park, Karori Stream at Makara Mountain Bike Park and the Waiwhetu Stream at Wainuiomata Hill Bridge.The data in the present study for site 10 of Karori Stream is compared and discussed further in Chapter 4 with data from the 2009-2010 study [4], and with the unpublished data of the ongoing GWRC monitoring program summarised in Figure A 1.8, [34], in Appendix 1. In addition, a study conducted by the GWRC [8], undertook a base flow survey for 7 sites, in addition to storm runoff monitoring. The concentration of dissolved $\mathrm{Cu}$ and $\mathrm{Zn}$ in 3 samples exceeded the ANZECC (2000) TVs. The data of Wingfield Place and Kenepuru sites of Porirua Stream are compared and discussed with the corresponding sites in this study in Section 4.2.

Furthermore, over the last decade, the GWRC has provided, in three separate investigations [7-8, 35], evidence that urban catchment delivers contaminated water during runoff events, which could adversely affect the benthic community. Several water contaminants have been considered in these studies, such as heavy metals, 
particularly $\mathrm{Cu}, \mathrm{Zn} \mathrm{Pb}, \mathrm{Cr}, \mathrm{Ni}$ and $\mathrm{Fe}$ (in both forms: dissolved and sedimentassociated); polycyclic aromatic hydrocarbons (PAHs), nutrients, pesticides, suspended solids and $\mathrm{pH}$. The studies are discussed further below, particularly the pollutants of concern in this study. The data from the three studies is discussed and compared with the results of our study in greater detail in Section 4.2 and 5.3.

The earliest storm runoff monitoring study in the Wellington region was in 1998, an investigation into the effects of transport on water quality in Wellington carried out by John Sherriff [35]. The investigation was carried out in an area where it was believed that road runoff was not affected by any storm water runoff from any other source prior to discharge into the drainage system. The investigation suggested that the majority of the contaminants were carried by the first flush, and a much reduced amount was carried in a subsequent storm runoff. The data for dissolved $\mathrm{Cu}$ and $\mathrm{Zn}$ concentrations are discussed in Section 5.3 and compared with paved surface runoff data from this study.

The second investigative programme was undertaken between 2001 and 2004 by the GWRC. The analyses and reporting were undertaken by consultants Kingett Mitchell Ltd [7]. The investigation showed the results of a total eleven storm runoff events at eleven different sampling sites with different catchment types; industrial, commercial and residential. It was found that dissolved $\mathrm{Cu}, \mathrm{Ni}, \mathrm{Co}$ and $\mathrm{Zn}$ concentrations exceeded the ANZECC (2000) TVs. Dissolved Fe and Pb did not exceed the sustained toxicity triggers (ANZECC (2000) TV and CTV). In comparison to the guidelines, the most elevated dissolved metal concentrations were for $\mathrm{Zn}$, which were markedly elevated at two industrial catchments.

In 2005 the GWRC embarked on a series of long term (2 years) storm water quality examinations at seven sites on five urban streams in the Wellington region where the concept of first flush was introduced [8]. Dissolved metals were analysed in eighteen storm runoff samples and it was concluded that:

- Dissolved concentrations of $\mathrm{Cu}$ and $\mathrm{Zn}$ exceeded their respective ANZECC (2000) TV in all first flush and composite samples (later duration sample of runoff). 
- Two first flush and eight composite samples exceeded the USEPA (2006) hardness adjusted $\mathrm{CMC}$ for $\mathrm{Cu}$.

- Dissolved Zn exceeded the USEPA (2006) hardness-adjusted CMC guideline in five first flush and three composite samples.

- Overall, the concentrations of dissolved $\mathrm{Cu}$ were the highest in the composite samples. In contrast, the first flush samples had the highest concentrations of dissolved $\mathrm{Zn}$.

Further discussions of these studies are presented in Section 4.2.

\subsubsection{Other New Zealand Literature}

In New Zealand, there have been only a few studies which have measured heavy metals in storm runoff during the last decade. In a similar manner to Section 2.2.1, an overview is provided here, and details are discussed more thoroughly in Section 4.2 .

Firstly, Rotorua District Council in association with NIWA designed a monitoring program to capture storm runoff water during the period 1999-2002. A total number of thirteen storm runoff events were sampled from three different catchment types; residential, commercial, and industrial [6]. Several parameters commonly associated with urban storm water were measured e.g.; electrical conductivity, suspended solids, chemical oxygen demand, heavy metals (particularly dissolved and solid-attached $\mathrm{Cu}$, $\mathrm{Zn}, \mathrm{Fe}$ and $\mathrm{Pb}$ ), petroleum hydrocarbons, indicator microbes, faecal coliforms and $E$. coli. An assessment of potential adverse impacts on water residing organism was made using several means such as toxicity testing and observation of biological surveys in stream and lakes close to storm discharges [6]. 
In 2005, the Auckland Regional Council conducted study on the identification and quantification of heavy metals $(\mathrm{Cu}, \mathrm{Zn}$, and $\mathrm{Pb})$ in three catchment types; commercial, industrial and residential in the Auckland region [36]. The mass budgets (the result of multiplying the contaminant concentration with associated water flow) for $\mathrm{Zn}, \mathrm{Cu}$ and $\mathrm{Pb}$ in the storm water for the three catchments were determined. As a result, the contributions of the known metal sources ( $\mathrm{Zn}$ : vehicle tyres, galvanised building materials, paints, industrial activities, natural soils; $\mathrm{Cu}$ : vehicle brake pads, plumbing, industrial activities, natural soils) to metal loads in urban storm water were identified. Roof runoff, particularly from galvanised roofs, accounted for almost all the $\mathrm{Zn}$ found in commercial and industrial catchments. In the residential catchment on the other hand, roofs contributed only to $45 \%$ of the total $\mathrm{Zn}$ load concentration. In all catchment types, roads contributed only a minor proportion of the total load, as shown in Figure 2.5. The major contributor for $\mathrm{Cu}$ in the three catchments was unidentified. The calculation of the mass budget does not account for runoff coming from walls and fittings, Figure 2.6. However, analysis of sediment adjacent to buildings showed very low levels of $\mathrm{Cu}$, indicating a low contribution from this source [36].
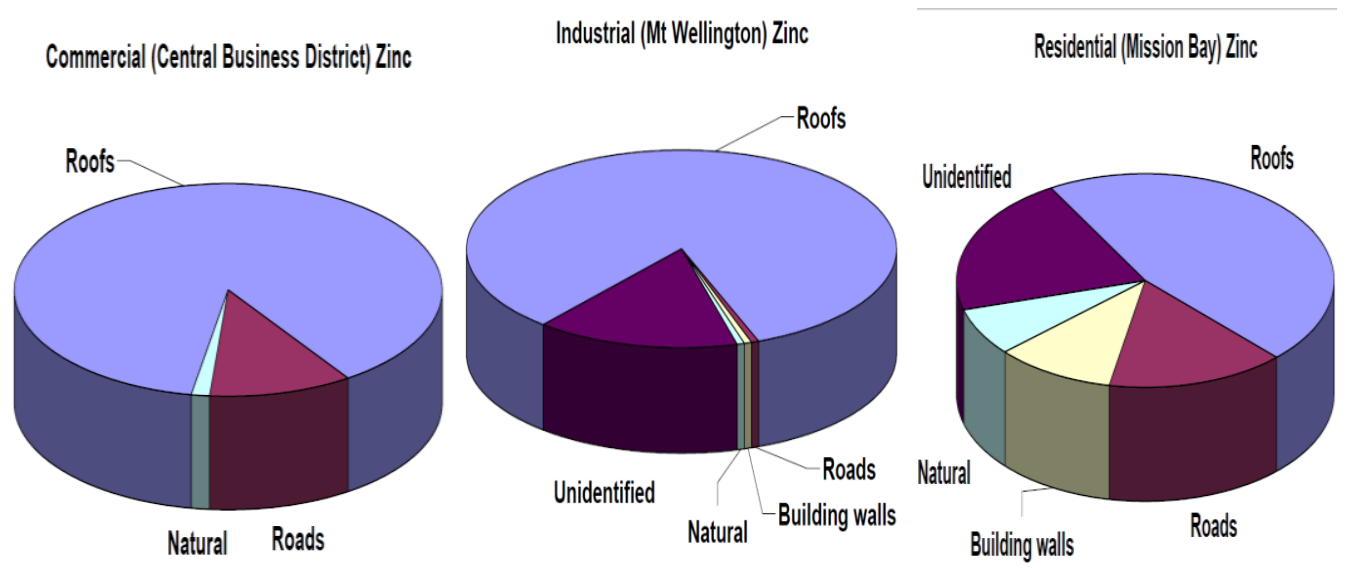

Figure 2.5 Total mass budgets for zinc in the three catchments (left to right 47, 176 and $26 \mathrm{~kg} / \mathrm{year}$ ) and the contribution of each known sources, obtained from [36]. 

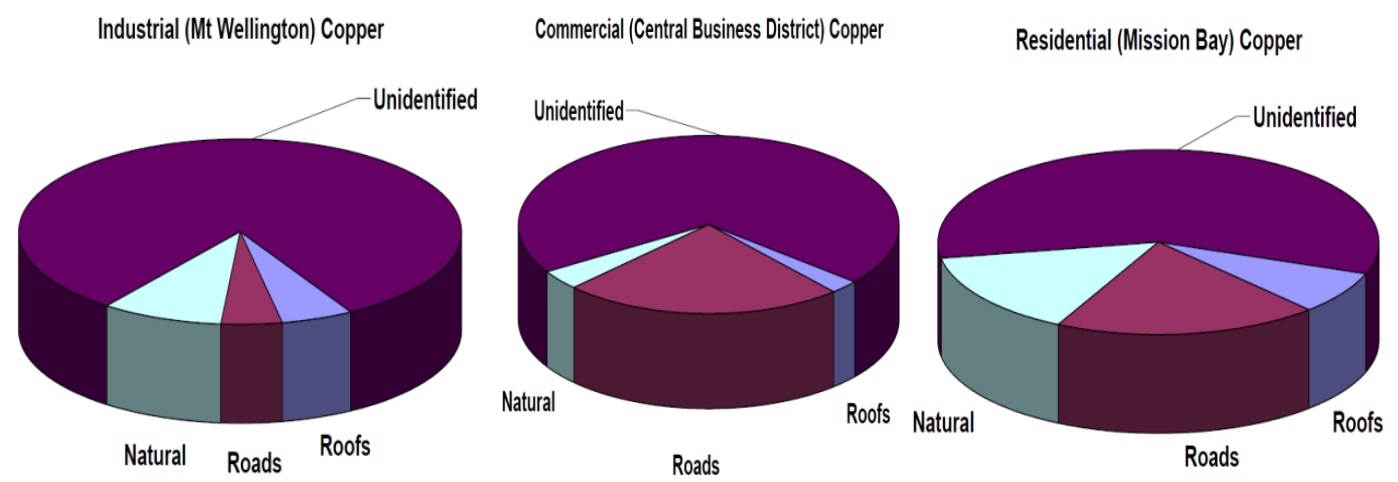

Figure 2.6 Total mass budgets for $\mathrm{Cu}$ in the three catchments (left to right 4.59, 4.21 and $3.57 \mathrm{~kg} / \mathrm{year}$ ) and the contribution of each known source, obtained from [36].

More recently, over the period of 2007-2008, Wicke and co-workers developed a rainfall contaminant relation model for an urban catchment in Christchurch (a car park located in the University of Canterbury campus) [37]. The concept of first flush was considered and investigated. A total of six storm runoff events were monitored for heavy metals, $\mathrm{Cu}$ and $\mathrm{Zn}$ in particular. The results indicated that A) The concentrations of dissolved $\mathrm{Cu}$ and $\mathrm{Zn}$ in the first flush were higher than the composite (later duration) samples. B) These metals were measured at levels higher than ANZECC (2000) TVs. The data is compared against our findings of paved surface runoff on Section 4.5.2.

\subsubsection{International Literature}

There is increasing recognition in many countries for storm associated issues, particularly the presence of hazardous contaminants. The literature is rich with studies describing monitoring programs and remediation solutions. In this section, a summary of 4 studies is discussed.

The first flush phenomenon in storm runoff collected from a highway in California, USA was studied over a four year period by Stenstrom, et. al [29]. More than ten associated storm runoff parameters were examined including heavy metals. Generally, most of the parameters monitored in this study had higher concentrations 
in first flush of the runoff than later stages of the runoff, confirming the existence of the first flush phenomenon. One should bear in mind that California weather is typified by rain events preceded by long dry weather periods. The authors attributed the first flush phenomenon to the nature of runoff, which generally has lower flow rate at the beginning of the storm than at the end of the storm, causing the dilution of the contaminants in those events that had longer duration. Another proposal was that the majority of the contaminants were flushed off in the first water-surface contact resulting in high concentration at the beginning of the runoff. It was concluded that, treating the first portion of storm runoff is cost effective. Figure 2.7 and Figure 2.8 are selected two plots of the variation of total and dissolved $\mathrm{Cu}$ and $\mathrm{Zn}$ concentration of the monitored contaminant versus time, for two monitored runoff events, where the first event displayed first flush for $\mathrm{Cu}$ and $\mathrm{Zn}$ but the second event did not [29].

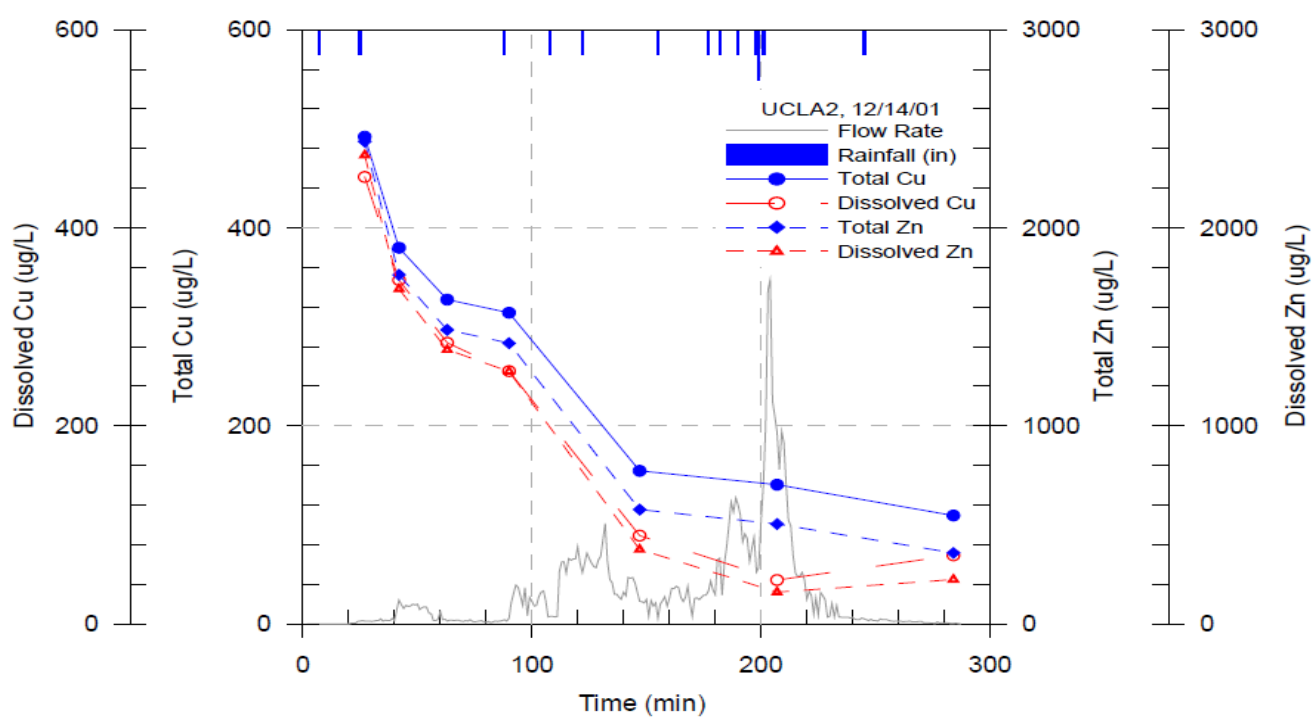

Figure 2.7 Plot of total and dissolved $\mathrm{Cu}$ and $\mathrm{Zn}$ as a function of time. The highest concentrations of total and dissolved $\mathrm{Cu}$ and $\mathrm{Zn}$ are in the initial rainstorm runoff compared to the remainder runoff of the storm, obtained from [29]. 


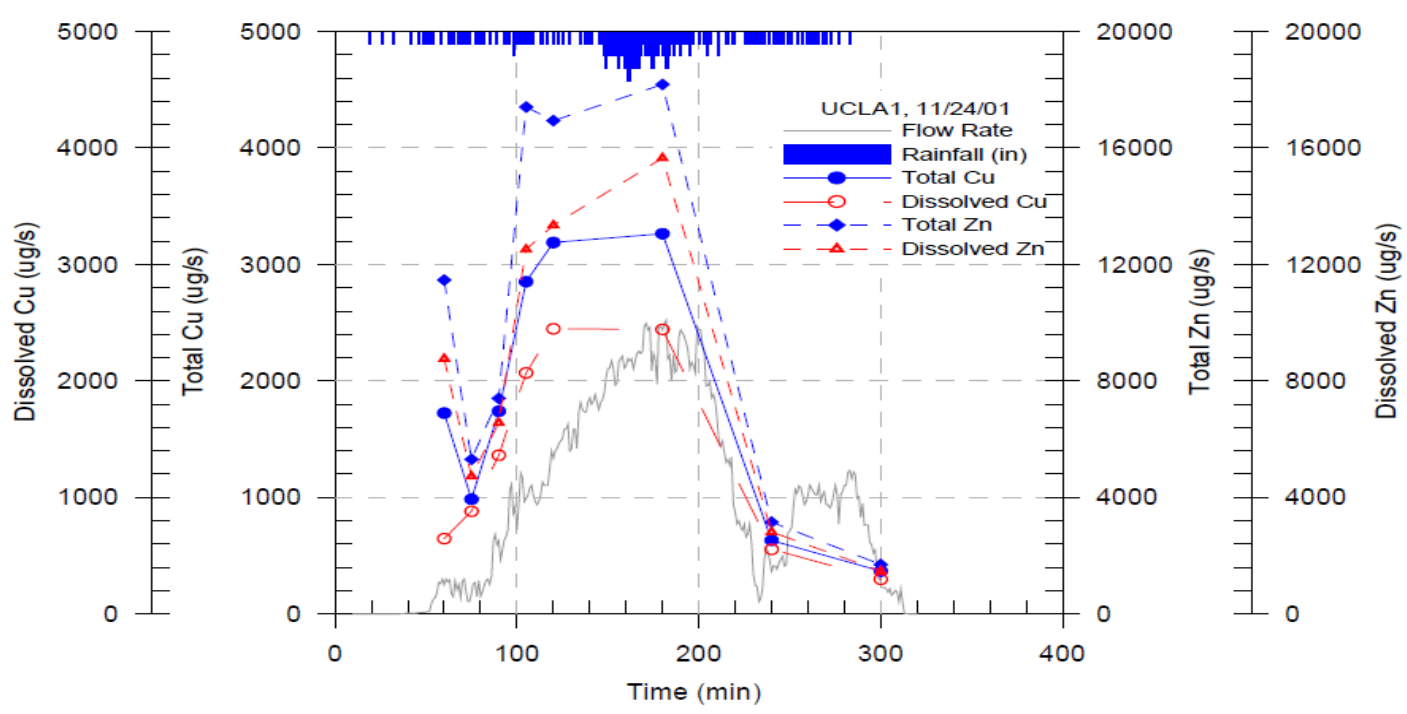

Figure 2.8 Plot of total and dissolved $\mathrm{Cu}$ and $\mathrm{Zn}$ as a function of time. An example of storm runoff that did not show the first flush effect, where the concentrations of total and dissolved $\mathrm{Cu}$ and $\mathrm{Zn}$ were higher at later stages of the storm, obtained from [29].

Gnecco et al. [54], examined first flush phenomenon related to runoff from a variety of urban surfaces (roof and road runoff) in 12 rainfall events in Genoa, Italy. In this study they measured dissolved metals concentrations ( $\mathrm{Zn}, \mathrm{Pb}, \mathrm{Cu}, \mathrm{Cd}, \mathrm{Cr}$ and $\mathrm{Ni}$ ). The concentrations of $\mathrm{Cu}, \mathrm{Pb}$ and $\mathrm{Zn}$ exceeded the European water quality standards in $70 \%$ of the monitored samples of road runoff.

In Xiamen City, China, Wei et al. [61], found that the concentrations of heavy metals $(\mathrm{Cu}, \mathrm{Pb}, \mathrm{Cd}$ and $\mathrm{Zn})$ in storm runoff from parking lots and roads were much higher than the concentration of heavy metals in samples from lawn runoff. First flush samples contained higher concentrations of heavy metals, organic matter and nutrients than the samples collected at later time of the runoff events.

Asaf et al. studied the variation of chemical and isotopic compositions of urban storm water in the coastal city of Ashdod, Israel [62]. In this study, 68 samples of 46 rainwater events were collected over a two year period (2000-2002). Land use was not a big contributor to the total concentrations of trace metals. The concentrations of trace metals in $97 \%$ of the storm water samples were below the drinking water standard. 


\subsubsection{Summary of the Literature}

Urban storm water discharges during wet-weather flow deliver pulses of contaminated water to many receiving water bodies. There has been a limited amount of published work on this subject in recent years in New Zealand. The impact and effect magnitude of urban storm on water quality depends on the characteristics of the storm and catchments. A study conducted by the GWRC showed that in a depositional environment such as filter feeding organism and sediment, elevated levels of heavy metals have been observed in places adjacent to urban areas [38]. Accumulation by flora and fauna, which could result in a reduction in biodiversity, is one of the most concerning adverse effects. This could have a negative impact on human health. 


\section{Chapter 3}

\section{Field Work and Experimental}

\subsection{Field Work and Sampling Strategies}

As previously mentioned, the primary objective of this work was to determine the concentrations of the three dissolved metals during base flow (dry weather) and wet weather flow in the Wellington region. A monitoring program was established to capture these two sample types. In the case of wet weather flow samples there are two different sub-types of samples. The first type is a single grab sample collected during runoff events from the studied sites (so-called runoff samples), which were less difficult and challenging than the second type. The second type of samples are obtained while monitoring storm runoff continuously from the beginning which lead to characterise the storm runoff with two samples, first flush and composite samples, defined in Section 3.1.3. The collection of these samples was associated with challenges involving an enormous amount of work. Water flow information was not measured, so event mean concentration and annual mass load cannot be calculated from the data presented in this work. To achieve the identification of possible sources of contaminants, sampling and analysis of three categories of sample was carried out: A) atmospheric rainfall samples, B) roof samples and C) paved surface runoff. This section is intended to provide details of the sampling protocols and a review of associated literature.

\subsubsection{Base flow Samples}

A monitoring program was established to collect base flow water samples. A series of sampling events were undertaken on a weekly basis. In most cases, a sampling event covered all monitored sites. The program was started on 7/01/2011 with seven sites (sites 1-7), four sites on Porirua Stream, one site on Kenepuru Stream, and two sites on Takapu Stream. On 03/03 /2011, six additional sites were added to the program (sites 8-13): two sites on Karori Stream and one site on a tributary of Karori 
Stream; two sites on Makara Stream, and one site of Ohariu Stream. The purpose of including sites 8-13 was to include more residential sites to the west of the Wellington region and importantly to add rural sites (sites 11-13) to the program. In Appendix 1, the total number of base flow samples for each site is shown.

\subsubsection{Storm Runoff Samples}

Previous work by the GWRC [7] conducted storm water runoff sampling based on time-weighted average concentrations; a composite sample from six separate samples. The sampling commenced within the first hour of the storm commencing and continued at hourly intervals. Similarly, Rotorua District Council conducted storm runoff sampling based on flow-weighted samples and a conclusive composite sample for each storm [6]. An automatic sampler was utilised which was programmed to collect samples as soon as a water flow increase was observed. In both studies, each storm runoff was represented by one composite sample, therefore, first flush was not considered.

In the current study a storm runoff event is monitored by a single grab sample collected manually at random times during the runoff, excluding the first flush. This was to enable the author to obtain storm runoff samples from more than one studied site during the same runoff event. In all sites, at least five storm runoff events were sampled; for example, sites 8-13. Sites 1-7 have a larger number of storm runoff samples due to the longer sampling period. The total number of storm runoff samples is detailed in Appendix 1 with each site.

Having base flow and storm runoff datasets, one can use the value of the medians of dissolved metal concentrations for an evaluation against sustainable and acute toxicity guidelines. The ANZECC (2000) noted that the evaluation of a certain contaminant concentration against the guidelines should only be made upon several monitored concentrations [11], which has been fulfilled by the protocols conducted in this study. In addition, acquiring the base flow data set provides an additional comparative element to evaluate the relation between site characteristics and storm water discharges. 


\subsubsection{Continuous Monitoring of Storm Runoff: First Flush and Composite Samples}

Sampling first flush always is difficult and requires meticulous preparation. The weather forecast is an important aspect of first flush sampling. It was necessary to obtain a reliable forecast in order to prepare for sampling events. The New Zealand meteorological service webpage www.metservice.com was consulted for upcoming rainfall events, however, it does not provide an absolute time and there are large variations between the start of the rain in Wellington City and at the collection sites. Usually, first flush sampling involved 1-2 hours of waiting before they actually could be collected. Sampling strategies is an arguable matter amongst researchers, particularly, how much of the storm runoff should be considered as first flush [27]. Herein, three opinions are provided and the protocol used in this work is described.

The GWRC [8] conducted first flush sampling by using an ISCO automatic sampler that triggers automatically when water level rises $35 \mathrm{~mm}$ over 15 minutes (water depth dependent). The first flush sample was the average composition of the three samples collected at five minute intervals, and the composite sample (later duration of the storm) consisted of a further eight samples taken at 20 minute intervals [8]. On the other hand, in the study done in California [29], first flush is the mathematical mean concentration value of a certain pollutant during the first hour of runoff samples. Composite samples were obtained using the mean of further runoff samples, collected at hourly intervals, between 4 and 7 hours, as shown in Figure 3.1. The sampling was flow dependent, sampling commenced as soon as the flow was observed, by an automatic sampler. Finally, a study done in Christchurch in 2008 [37] proposed that first flush is the composition of the first 30 minutes samples of storm runoff and the composite sample is the composition of the later duration samples of the storm runoff. The sampling was accomplished using an automatic sampler that collected the samples as soon as water flow was observed. 


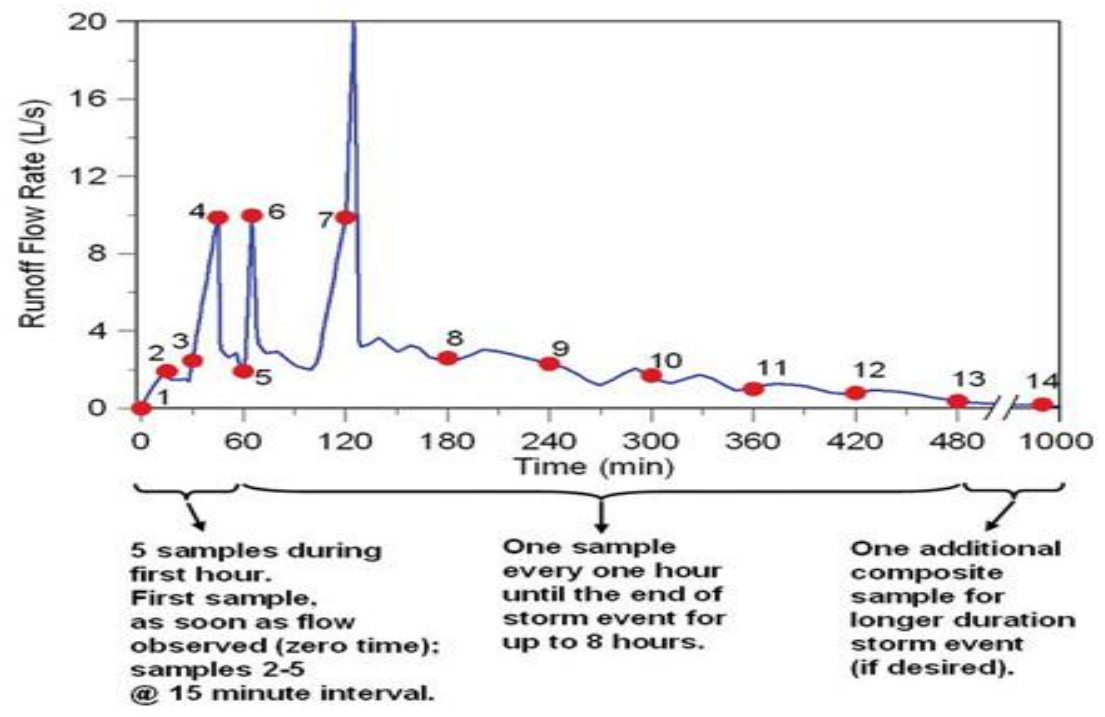

Figure 3.1 General sampling protocol for first flush and composite samples, obtained from [29].

In this work first flush is considered to be the mathematical mean of the concentrations of dissolved metals in samples collected in the first 25 minutes collected at intervals of 5-15 minutes, as shown in Figure 3.2. Composite samples were obtained using the same mean, but for samples collected after the first flush, at different time intervals of 10 minutes to 1 hour with a maximum monitoring time of 6 hours, as shown in Figure 3.2. Note that there were some short storm events therefore only one sample was collected after first flush. All samples were collected manually and the collection was commenced five minutes after rainfall started. It should be remembered that first flush is used to express contamination levels at the beginning of the storm compared to later stages of the same storm runoff. 


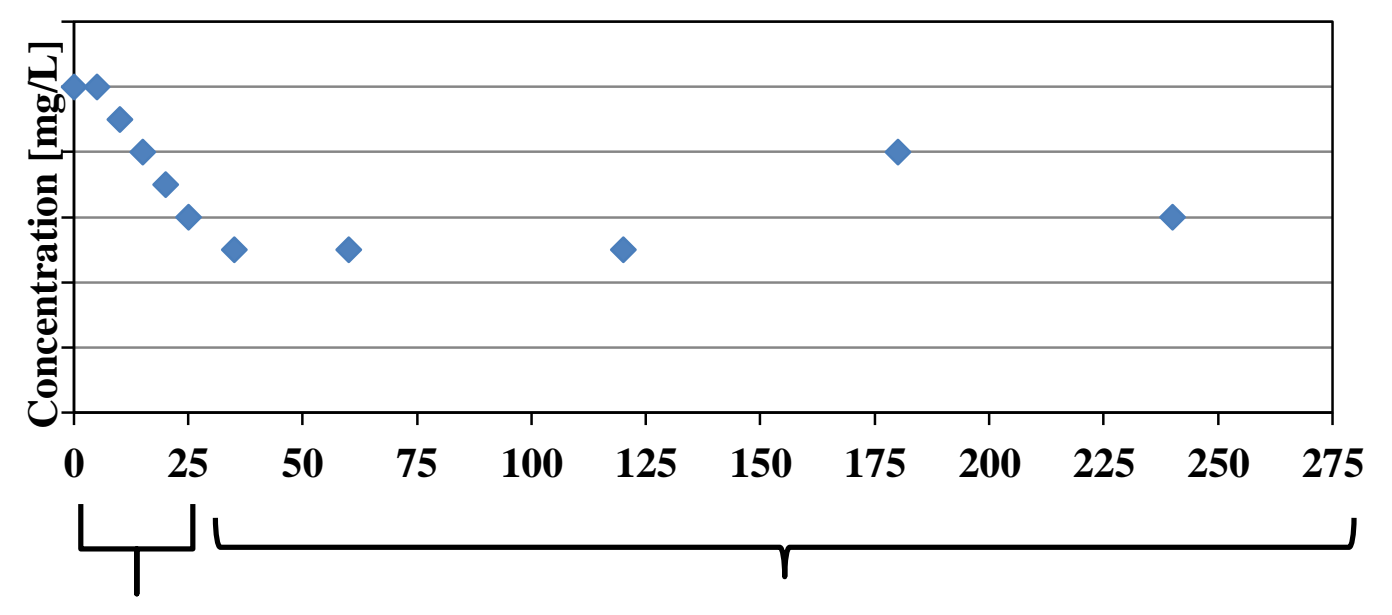

First flush:

the average of the concentrations in the samples collected during the first 25 minutes of the runoff

Composite:

the average of the concentrations in the samples collected during the later runoff

Figure 3.2 General definitions and sampling protocols for first flush and composite samples.

In total, nine storm runoff events were monitored: Four events at site 1 (one event is a runoff from Middleton Road, adjacent to site 1, this is explained further in Section 3.1.6), two events at site 8; and single events at sites 4, 5 and 9. Additionally, the effect of the length of dry weather before to the storm on first flush was examined between events monitored at sites 1 and 8, and this is discussed in Section 4.2.4. Complete details, in terms of collection time intervals, concentrations of dissolved metals for each collected sample during the runoff, length of antecedent dry weather, and temporal variation of the concentrations of dissolved metals for each event are presented in Appendix 1 for the respective sites. 


\subsubsection{Atmospheric Rainfall Samples}

Rain samples were collected between December 2010 and July 2011. Weather forecasts were consulted in advance from www.metservice.com. Once rainfall was predicted, a non-metallic rainwater collector, as shown in Figure 3.4, was placed on the collection site. Sampling was carried out until approximately $500 \mathrm{ml}$ was collected. In the case of short events, the collector was removed after the rain had stopped; in this way contamination of rain samples by dry deposition was avoided. The samples were collected mainly on the roof of the second floor of Laby Building, School of Chemical and Physical Sciences (SCPS), of Victoria University of Wellington, Kelburn, Wellington, New Zealand. In addition, three atmospheric rainfall samples were collected at the Mt Victoria road tunnel, which has a high traffic density and four rural atmospheric rainfall samples were collected at site 13, located near 257 Takarau Gorge Road.

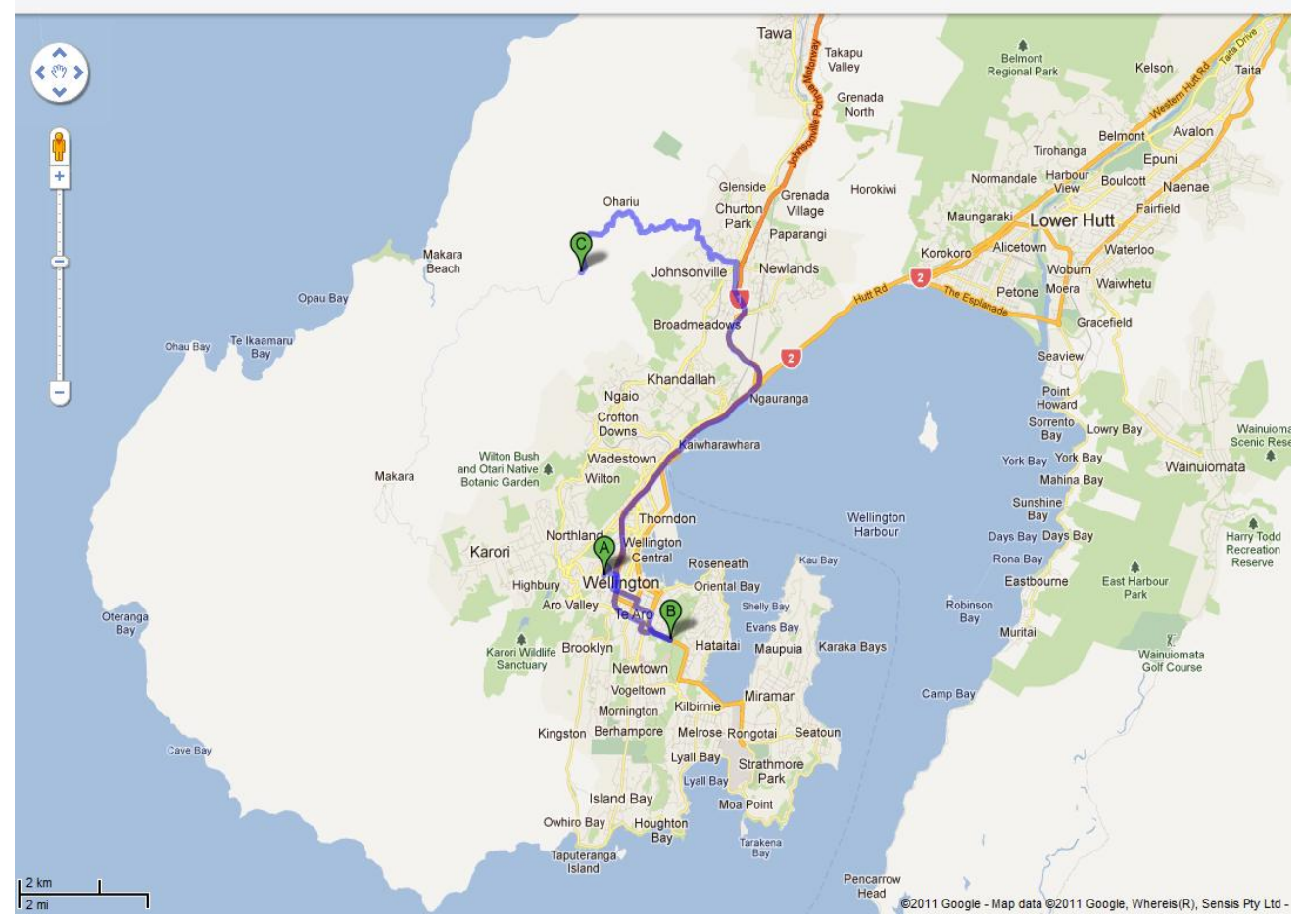

Figure 3.3 Wellington map, locations of sites for the atmospheric rainfall sampling. A: VUW, B: Mt. Victoria tunnel, C: 257- Takarau Gorge Road, obtained from [39]. 

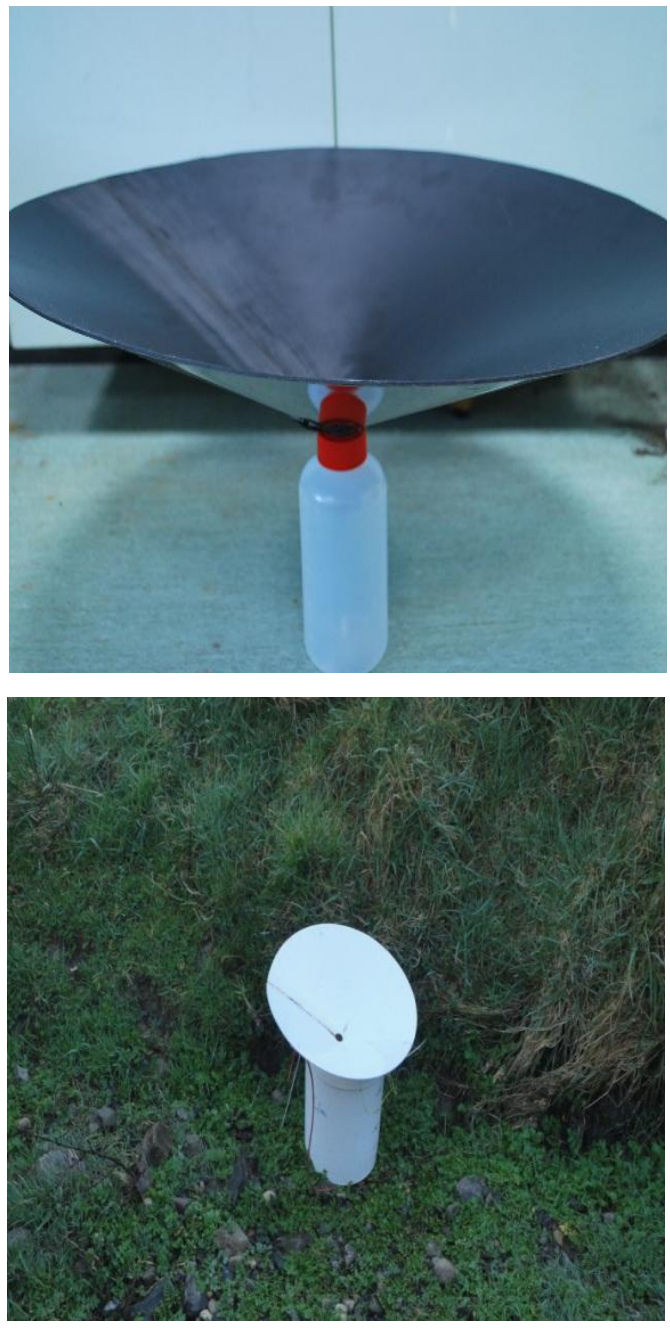

Figure 3. 4 Pictures of non-metallic atmospheric rainfall samplers: before placing in the holder and after placing in the holder and at the rural site.

\subsubsection{Roof Runoff Samples.}

Roof runoff samples were collected from residential and commercial buildings located in Wellington Central, Porirua, Tawa, Karori and Lower Hutt. The samples were collected from outer pipes of the gutter systems that discharge roof runoff to either storm water drainage systems or directly to the ground. 
Roof samples were divided into two categories. The first class aimed to capture roof runoff samples during random times of the runoff events, excluding first flush. Runoff from two roof types was measured: Galvanised roofs (the painting quality varied from moderate to bad) and tile roofs. Galvanised roofs are the majority of the samples due to their prevalence and ease of accessibility. The second group of samples involved an examination of first flush in roof runoff. Therefore, weather forecasts were checked for upcoming rainfall events. Galvanised roofs were selected for this purpose, due to ease accessibility. In terms of sampling strategies, one sample was collected as soon as the runoff was observed and the other sample (socalled delayed-runoff sample) was collected at a later time, there was at least a one hour difference between the two collections.

\subsubsection{Paved Surface Runoff Samples}

Another class of samples was obtained as a runoff from paved surfaces. These samples were collected in accordance with the storm runoff sampling protocol. The paved surfaces chosen were parking areas, roads, and land utilized for human entertainment purposes, located adjacent to one of the monitoring sites or to VUW, Kelburn campus. The samples were collected before the runoff had entered the storm water system or had mixed with stream water. As mentioned earlier, in 3.1.3, a monitoring of a road runoff (Middleton Road) was done at site 1. The samples were obtained from a drainage pipe that drains storm water from a section of the road and this portion of the road probably does not have roof runoff (or little). In the same event, another first flush sample was collected at site 1 but from different drainage pipe that drains runoff water from Wingfield Place which passes through a residential area and could contain roof runoff (this sample was not associated with a composite sample, the water level rose very quickly and the sampling had to stop for safety reasons). 


\subsection{Laboratory Work}

\subsubsection{Pre-sampling Preparation}

The work was performed in a clean area to avoid any introduction of contamination to the analysed water samples. All water samples were obtained in $510 \mathrm{ml}$ polyethylene bottles. Before any sampling took place, the containers were washed three times with distilled water, once with $2.5 \mathrm{M} \mathrm{HNO}_{3}$, once with $0.1 \mathrm{M}$ ethylenediaminetetraacetic acid (EDTA), and finally rinsed four times with distilled water. Bottles were allowed to dry out, inside a fume hood, and then they were closed with the lids and placed inside sealed plastic bags. The atmospheric rainfall samplers, glassware and other laboratory equipment were treated in the same method. During sampling, the bottles were rinsed twice with sampled water and then filled. The analysis of heavy metals was performed as soon as possible after the sampling with no holding time. This procedure fits well with the recommended sampling criteria protocol [40].

\subsubsection{Analytical Procedure}

\subsubsection{Determination of Dissolved Metal Concentrations}

Flame Atomic Absorption Spectroscopy (FAAS) was used to analyse the three metals in water samples. FAAS involves irradiation of a sample that has been aspirated and atomised into an oxy-acetylene flame with monochromatic light, measuring the absorption of entering light which is proportional to the concentration of analysed elements. Each element absorbs light at a characteristic wavelength; hence a change in the radiation source is required for each analyte. The detection limits for the studied elements are in the range of 0.01-0.05 mg/L [40-41]. Table 3.1 shows calculated ${ }^{2}$ detection limits for FAAS. Calibration curves were established with 5 variable concentrations in the range of $(0.00-1.5 \mathrm{mg} / \mathrm{L})$ for $\mathrm{Cu}$ and $\mathrm{Zn}$ and (0.00- $9.00 \mathrm{mg} / \mathrm{L}$ ) for $\mathrm{Fe}$ before the analysis took place (examples of typical calibration curves are given in appendix 2 Figures A2.4-A2.6). The determination of

\footnotetext{
${ }^{2}$ The calculations are based on the recommended method in [52].
} 
the concentrations of the studied metals is obtained after a triplicate analysis on FAAS. It should be noted that the determination of dissolved metals concentrations is usually preformed by Inductively Coupled Plasma Mass Spectrometry (ICP-MS) which has a very low detection limits for the analysed metals, as low as $50 \mu \mathrm{g} / \mathrm{L}$. Unfortunately, this instrument was not available for the daily analysis and the external analysis is highly expensive.

Table 3. 1 Calculated ${ }^{3}$ detection limits for $\mathrm{Cu}, \mathrm{Zn}$ and $\mathrm{Fe}$.

\begin{tabular}{cc}
\hline Metal & $\begin{array}{c}\text { Limit of detection LOD } \\
{[\mathrm{mg} / \mathrm{L}]}\end{array}$ \\
\hline $\mathrm{Cu}$ & 0.04 \\
$\mathrm{Zn}$ & 0.01 \\
$\mathrm{Fe}$ & 0.045 \\
\hline
\end{tabular}

Based on the results obtained by the Greater Wellington Regional Council (GWRC) $[4,8]$ and the monitoring data during the earliest two months, the concentrations of dissolved $\mathrm{Cu}$ and $\mathrm{Zn}$ in some samples were below the detection limits of the FAAS technique. The detection limits are higher than the recommended chronic toxicity guidelines. To overcome this issue, a technique, called pre-concentration was used to enhance the concentrations in the analysed samples. Various reagents and methods have been utilised to enhance the concentration of $\mathrm{Cu}$ and other elements prior to their detection in natural waters. These methods include solvent extraction, precipitation, electrochemical analysis, chelation resins, and various chromatographic techniques. Table 3.2 shows some examples of materials and techniques used in the pre-concentration process for trace metals in natural waters.

${ }^{3}$ The calculated LODs are at good agreement with that reported in the literature, for example, [40]. 
Table 3.2 Various reagents and techniques used for pre-concentrating heavy metals in natural waters.

\begin{tabular}{|c|c|c|c|c|}
\hline Reference & Methods & Advantages & Disadvantages & Target Elements \\
\hline [42] & $\begin{array}{l}\text { Single drop micro-extraction } \\
\text { into organic solvent }\end{array}$ & $\begin{array}{l}\text { Inexpensive, easy operation and few } \\
\text { complications }\end{array}$ & $\begin{array}{l}\text { Slow kinetics and } \\
\text { instability of the drop }\end{array}$ & $\begin{array}{l}\text { Suitable for a wide } \\
\text { range of elements. }\end{array}$ \\
\hline$[43]$ & $\begin{array}{l}\text { Column of Dowex Al chelating } \\
\text { resin and of silylated silica gel. }\end{array}$ & $\begin{array}{l}\text { Simple procedure and high enrichment } \\
\text { and recovery factors. }\end{array}$ & Slow process & $\begin{array}{c}\text { Ba, Mn, Co, Zn and } \\
\text { Eu. }\end{array}$ \\
\hline [44] & Hyphan cellulose ${ }^{4}$ & satisfactory recovery percentage & Time consuming & $\mathrm{Cu}$ \\
\hline [45-46] & Anodic stripping voltamtry ${ }^{5}$. & Fast and simple procedure. & $\begin{array}{l}\text { High detection limit } \\
\text { and few interferences }\end{array}$ & $\begin{array}{l}\text { Wide range of } \\
\text { elements. }\end{array}$ \\
\hline [47] & $\begin{array}{l}\text { Solvent extraction by1-nitroso- } \\
\text { 2-naphthol and Dowex MWC-1 } \\
\text { resin column }\end{array}$ & $\begin{array}{l}\text { Simple procedure and } \\
\text { low detection limit }\end{array}$ & $\begin{array}{l}\text { Reagents consuming } \\
\text { and expensive }\end{array}$ & $\mathrm{Zn}$ and $\mathrm{Cu}$ \\
\hline [48] & $\begin{array}{l}\text { Ethylenediamine functionalized } \\
\text { self-assembled monolayers on } \\
\text { mesoporous supports }\end{array}$ & $\begin{array}{c}\text { Fast kinetics } \\
\text { and } \\
\text { High sorption capacities }\end{array}$ & $\begin{array}{l}\text { Complicated } \\
\text { preparation of the } \\
\text { sorbent }\end{array}$ & $\mathrm{Cu}$ \\
\hline [49] & $\begin{array}{l}\text { Metal ions are sorted as } \\
\text { pyrocatechol violet complexes } \\
\text { on activated carbon column, } \\
\text { followed by detection on AAS }\end{array}$ & fast and simple method & $\begin{array}{l}\text { Chemical consuming } \\
\text { method and } \\
\text { expensive. }\end{array}$ & $\begin{array}{c}\mathrm{Cu}, \mathrm{Mn}, \mathrm{Co}, \mathrm{Cd}, \mathrm{Pb}, \\
\mathrm{Ni} \text { and } \mathrm{Cr}\end{array}$ \\
\hline$[44,48,50-51]$ & Chelex-100 & $\begin{array}{l}\text { Simple, cheap and excellent recovery } \\
\text { percentage }\end{array}$ & Slow kinetics & $\begin{array}{l}\text { Wide range of } \\
\text { elements. }\end{array}$ \\
\hline
\end{tabular}

\footnotetext{
${ }^{4}$ Hyphan cellulose is a chelating resin in a microcrystalline form with chelating groups 1-(2-hydroxyphenylaza)-2-naphthol.

${ }^{5}$ Deposition of $\mathrm{Cu}$ on a suitable working electrode and reverse the reaction in a smaller volume afterwards, and/or observe the correspond signal.

${ }^{6}$ Dowex MWC-1 is chelating resin with a sulfonic acid functional group as the chelating sites.
} 
Among the wide range of pre-concentration methods and reagents available, Chelex100 is a chelating resin that has durable, insoluble and compatible properties. The polymeric backbone of the resin is polystyrene cross-linked with divinylbenzene, functionalized with iminodiacetate groups as the chelating sites. This resin traps metals from aqueous solution in an efficient and selective way, depending on the $\mathrm{pH}$ and the type of ions of the solution [44, 48, 50-51]. It is supplied in the sodium form with 50-100 mesh grain size (obtained from Sigma). This form is very stable and has excellent shelf life; it can be recovered after use by a two steps, firstly soaking in acid (2.5 $\mathrm{M} \mathrm{HNO}_{3}$ in this work) followed by immersion in a strong base $(0.3 \mathrm{M}$ $\mathrm{NaOH}$ in this work) ${ }^{7}$ and warming [51]. In the light of these facts, Chelex-100 chelating resin was chosen as the pre-concentration method prior to the analysis of dissolved $\mathrm{Cu}$ and $\mathrm{Zn}$ (in these cases where it could not be directly measured) by FAAS.

$\mathrm{Cu}$ and $\mathrm{Zn}$ speciation studies have shown that fast dynamic adsorption of the metals is exhibited by Chelex-100 [50]. The time for complete uptake from the sample to the resin is some dispute. In the literature, opinions vary from couple of hours [51] to three days [50]. On the other hand, the influence of $\mathrm{pH}$ on metal uptake is agreed where protonation of carboxylates and the nitrogen donor group was reported to be complete at $\mathrm{pH} 2.0 \pm 0.1$. Therefore, complete metal elution is achieved by soaking the resin in an acid media. Complete $\mathrm{Cu}$ and $\mathrm{Zn}$ adsorption occurs at $\mathrm{pH} 5.5 \pm$ 0.3 [44, 48, 50-51]. In the light of the above facts, a pre-concentration technique using Chelex-100 was developed using a batch equilibration technique. Figure 3.5, is a schematic of the developed batch procedure for $\mathrm{Cu}$ and $\mathrm{Zn}$ pre-concentration in natural waters.

The decrease in volume from $500 \mathrm{~mL}$ to $15 \mathrm{~mL}$ enhances the concentration of dissolved $\mathrm{Cu}$ and $\mathrm{Zn}$ by a factor of 33. The procedure consists of two parts. Part $\mathrm{A}$ is to measure the concentration of Fe directly (to avoid particulate contamination, the samples must first be filtered using a $0.45 \mu \mathrm{m}$ pore size membrane), and second, to see whether or not dissolved $\mathrm{Zn}$ needs to be considered after the pre-concentration process, in parallel to $\mathrm{Cu}$. If the concentration of dissolved $\mathrm{Zn}$ is directly measurable on FAAS, which is commonly the case for residential and commercial sites, the

\footnotetext{
${ }^{7}$ There was no difference between the new and recovered forms of Chelex-100 in term of capability, refer to Table 3.3.
} 
samples were not measured again ${ }^{8}$ for dissolved $\mathrm{Zn}$ in the pre-concentrated samples (in the $15 \mathrm{~mL}$ ).

Part B is the pre-concentrating procedure. Chelex-100 chelates the dissolved form of metals and so, there was no need to filter with the $0.45 \mu \mathrm{m}$ membrane because Chelex-100 reacts only with dissolved form of metals, which saved an enormous amount of time, particularly on these occasions where large numbers of samples were being analysed. The $\mathrm{pH}$ of the $500 \mathrm{ml}$ has to be adjusted by adding ammonium acetate solution. The buffer solution was a 1:1 mixture of $2.5 \mathrm{M}$ of ammonium chloride and 2.5 $\mathrm{M}$ of acetic acid (reagents obtained from Panreac). The $\mathrm{pH}$ of the buffer was checked periodically.

After the adjustment of $\mathrm{pH}$, Chelex-100 (either new or recovered forms) was added after being washed with $0.1 \mathrm{M}$ ammonium chloride solution (for fast dissociation through the chelating process [44]). Clean magnetic bars were placed inside the plastic bottles and the samples were stirred for 24 hours, Figure 3.6, is a picture of a water sample containing all reagents and ready for stirring stage. Afterwards, the samples were filtered (with $70 \mu \mathrm{m}$ pore size) and Chelex-100 beads containing the $\mathrm{Cu}$ and $\mathrm{Zn}$ were isolated. A one hour contact between Chelex-100 containing $\mathrm{Cu}$ and Zn with 1:1 solution of $2.5 \mathrm{M} \mathrm{HNO} 3$ and $2.5 \mathrm{M} \mathrm{HCl}$ (supplied by Fisher Scientific) followed in order to elute the metals from Chelex-100. Note that all reagents used were metal free and of analytical grads. The latter solution has been reported to be the best ratio for the elution mixture [44]. Finally, a filtration was performed to isolate the Chelex-100. The $15 \mathrm{~mL}$ samples containing enhanced concentrations of metals were measured on the FAAS and the original concentrations in the $500 \mathrm{~mL}$ were calculated. For example, a sample that contains $0.0045 \mathrm{mg} / \mathrm{L}$ of dissolved $\mathrm{Cu}$ after pre-concentrating the sample, the FAAS measures $0.15 \mathrm{mg} / \mathrm{L}$ of $\mathrm{Cu}$. This assumes having $100 \%$ recovery and an enhancement factor of 33 . The procedure is time consuming and required considerable lab work, particularly, during the course of analysing storm water samples, which contain suspended solids. In these circumstances, the first filtration step becomes even more frustrating and time consuming.

\footnotetext{
8 There were some internal tests where the concentrations of dissolved $\mathrm{Zn}$ were measured directly and in the pre-concentrated samples. The results were always consistent.
} 


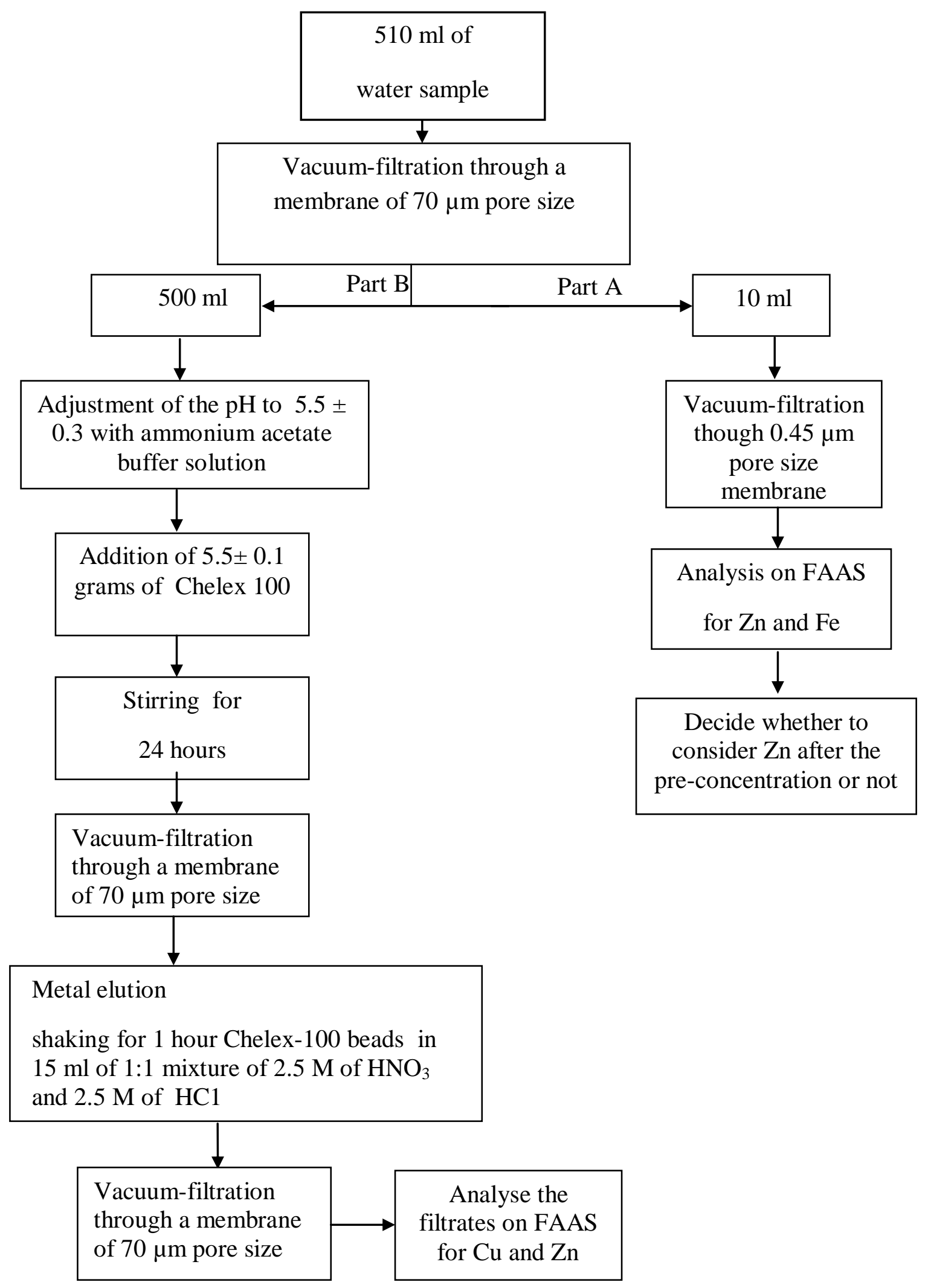

Figure 3.5 Schematic of the pre-concentration method employed to enhance the concentrations of $\mathrm{Cu}$ and $\mathrm{Zn}$. 


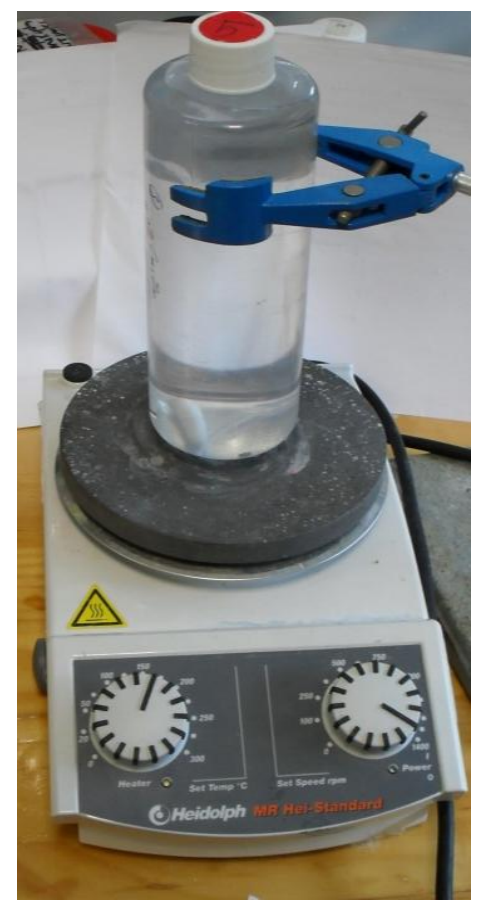

Figure 3.6 Stirring stage of water sample in the pre-concentration procedure.

The method has been assessed with standard solutions of the metals containing variable concentrations, in the range of 0.01-0.04 $\mathrm{mg} / \mathrm{L}$ (spiking real samples with variable metal concentrations and testing the recovery). As can be seen in Table 3.3, excellent average recoveries were achieved for both metals, confirming the success of the procedure. The recoverability testing experiments were operated on natural water, from site 1 that contained concentrations of $\mathrm{Cu}$ and $\mathrm{Zn}$, previously determined and set as blank. It is important to mention that the recoverability tests were done by a recoverable form of Chelex-100. The same conclusion was reported in other publications $[44,50]$, however, different procedures were applied.

In addition, an analysis by Inductively Coupled Plasma Mass Spectrometry (ICP-MS) was performed on six samples analysed earlier on FAAS. Table 3.4 shows the concentrations of dissolved $\mathrm{Cu}, \mathrm{Zn}$ and Fe obtained from FAAS and ICP-MS. The analysis reveals reasonable variations for dissolved $\mathrm{Cu}$ and $\mathrm{Zn}$ between the two analytical methods (except $\mathrm{Zn}$ in the sample from site 8). However, it should be noted that the samples were filtered two times, using $0.45 \mu \mathrm{m}$ membrane, before the analysis by ICP-MS took place, which could explain the lower concentrations of dissolved Fe obtained from the analysis by the ICP-MS. Colloidal particles of Fe could have been removed in the second filtration, leading to lower concentrations. 
Total relative uncertainties were calculated. Rectangular distributions $(\sqrt{3})$ were assumed for all uncertainty sources, including laboratory apparatus and FAAS. The calculations revealed that the measurements were associated with total relative uncertainty of $4.00 \%, 5.87 \%$, and $7.83 \%$ for $\mathrm{Cu}, \mathrm{Zn}$ and $\mathrm{Fe}$ respectively. Note that the calculations were performed in accordance with the recommendations in [52]. Calculations of consistency and relative uncertainty are detailed in Appendix 2.

Table 3.3 Examination of Chelex-100 recovery with variable concentrations of $\mathrm{Cu}$ and $\mathrm{Zn}$ concentrations.

\begin{tabular}{ccccc}
\hline Metal & $\begin{array}{c}\text { Number of } \\
\text { samples }\end{array}$ & $\begin{array}{c}\text { Initial concentration } \\
{[\mathbf{m g} / \mathbf{L}]}\end{array}$ & $\begin{array}{c}\text { Average } \\
\text { Concentration } \\
{[\mathbf{m g} / \mathbf{L}]}\end{array}$ & $\begin{array}{c}\text { Average } \\
\text { recoveries } \\
{[\%]}\end{array}$ \\
\hline \multirow{4}{*}{$\mathbf{C u}$} & $2^{*}$ & 0 & 0 & 0 \\
& 2 & 0 & 0.0035 & Not applicable \\
& 2 & 0.01 & 0.01 & 100 \\
& 2 & 0.02 & 0.02 & 100 \\
& 2 & 0.03 & 0.03 & 100 \\
$\mathbf{Z}$ & $2 *$ & 0.04 & 0.038 & 95 \\
\hline & $2 * *$ & 0 & 0 & 0 \\
& 2 & 0 & 0.02 & Not applicable \\
& 2 & 0.01 & 0.01 & 100 \\
& 2 & 0.02 & 0.02 & 100 \\
& 2 & 0.03 & 0.029 & 97 \\
\hline$*$
\end{tabular}

*: performance of Chelex-100 protocol in distilled water. **: the Concentrations of dissolved $\mathrm{Cu}$ and $\mathrm{Zn}$ in natural samples obtained by Chelex-100 without any addition.

Table 3.4 Comparison between the concentrations of dissolved $\mathrm{Cu}, \mathrm{Zn}$ and $\mathrm{Fe}$ obtained from the analysis by FAAS and ICPMS.

\begin{tabular}{lllllll}
\hline Site & \multicolumn{6}{c}{ Metal concentration [mg/L] } \\
\hline & \multicolumn{7}{c}{ Cu } & \multicolumn{2}{c}{ Zn } & \multicolumn{1}{c}{ Fe } \\
\hline $\mathbf{1}$ & FAAS & ICP-MS & FAAS & ICP-MS & FAAS & ICP-MS \\
$\mathbf{3}$ & 0.0070 & 0.0089 & 0.030 & 0.052 & 0.116 & 0.067 \\
$\mathbf{4}$ & 0.0042 & 0.0079 & 0.015 & 0.022 & 0.115 & 0.060 \\
$\mathbf{5}$ & 0.0063 & 0.0030 & 0.020 & 0.013 & 0.126 & 0.15 \\
$\mathbf{8}$ & 0.0048 & 0.0059 & 0.022 & 0.023 & 0.255 & 0.13 \\
Rainfall & 0.0075 & 0.0042 & 0.034 & 0.0047 & 0.100 & 0.02 \\
& 0.017 & 0.011 & 0.1 & 0.046 & 0.21 & 0.063 \\
\hline
\end{tabular}


It should be noted that the pre-concentration procedure had not been developed before 22/03/2011. Before this time, all the three metals in water samples had been analysed following part $\mathrm{A}$ in Figure 3.5. Hence, dissolved $\mathrm{Cu}$ and $\mathrm{Zn}$ (in a few cases) in base flow and storm runoff samples collected prior to this date were below the detection limit. Consequently they were not considered and were omitted from the subsequent statistical calculations. The number of omitted samples for $\mathrm{Cu}$ and $\mathrm{Zn}$ is detailed with data set of each site in Appendix 1. The concentrations of dissolved $\mathrm{Cu}$ that fell below the enhanced detection limit $(0.0012 \mathrm{mg} / \mathrm{L})$ were assumed to be equivalent to the enhanced detection limit and were introduced to the statistical calculations. The concentrations of dissolved $\mathrm{Zn}$ were always high enough to be measured either directly or by the pre-concentration method and therefore no assumptions were made. The assumption does not affect our judgment on whether the concentration of $\mathrm{Cu}$ exceeds the chronic toxicity trigger value (ANZECC (2000) TV and HMTV) or not, because the enhanced detection limit is lower than this guideline. In a similar manner, the concentrations of dissolved Fe that fell below the detection limit of $0.045 \mathrm{mg} / \mathrm{L}$ of FAAS particularly for base flow samples of Takapu Stream and Karori Stream sites, were assumed to be the detection limit. It should be noted that no assumptions were made for samples collected from atmospheric rainfall samples, roof, and paved surface runoff, because the guidelines are not intended to assess this type of water. 


\section{Chapter 4}

\section{Base Flow and Wet Weather Monitoring Outcome}

\subsection{Results}

The primary objective of the present project was to measure the concentrations of dissolved $\mathrm{Cu}, \mathrm{Zn}$ and $\mathrm{Fe}$ in base flow and investigate the impact of rain runoff on the level of contamination to see whether there was any degradation of water quality. Section 4.1 provides data obtained from the weekly monitoring program (base flow sampling), storm runoff sampling, and monitoring for first flush. For each site, unless stated, dissolved $\mathrm{Cu}$ and $\mathrm{Zn}$ data are presented separately in tables (Appendix 1) and visualised as box plots and compared against the ANZECC (2000) hardness modified trigger values chronic toxicity (HMTVs). Sites that do not have water hardness information are compared against the default ANZECC (2000) TVs directly without modification. Dissolved Fe data is treated in a similar manner to the data for $\mathrm{Cu}$ and $\mathrm{Zn}$, but in this case it is compared against the Canadian sustained Toxicity trigger Value (CTV). Additionally, storm runoff data is compared against the United States Environmental Protection Agency (USEPA 2006) Criteria Maximum Concentrations (CMC) values. Box plots present the data parameters, minimum, 25th percentile, median, 75th percentile and maximum as shown in Figure 4.1. The median values are the basis for all comparisons and discussions against the guidelines. The factor by which the respective toxicity triggers is exceeded is based on the median values and mentioned in the tables for each metal in Appendix 1. Additionally, the impact of storm runoff events on the dissolved metal contamination was evaluated using the medians of the collected data in base flow and runoff events. Results for first flush and composite samples are shown, details are in Appendix 1. The next Section (4.2) provides an overview and a discussion of the data in greater detail, with comparisons to previous works. 


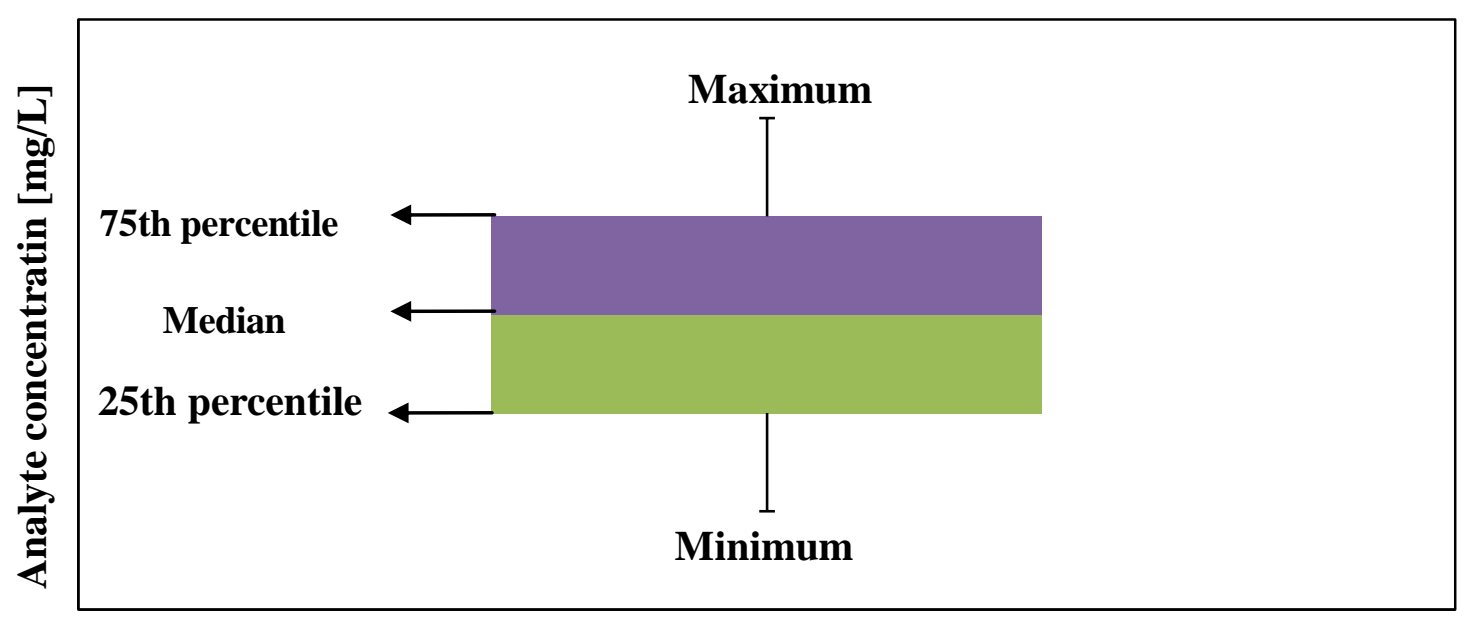

Sample type

Figure 4.1 Interpretation of box plot.

\subsubsection{Site1 Data}

A total 19 base flow and 10 storm runoff samples were collected at this site. Also, 3 storm runoff events were monitored for first flush resulting in 3 first flush and 3 composite samples. Site 1 is the most contaminated with the presence of high concentrations of dissolved $\mathrm{Cu}$ in base flow and run off events, this could be attributed to the fact that this site has low water flow or its location next to residential area. In fact, all dissolved $\mathrm{Cu}$, and the median dissolved $\mathrm{Zn}$ in base flow and storm runoff samples exceeded the HMTVs, as shown in Figure 4.2 and Figure 4.3. The median of dissolved $\mathrm{Cu}$ and $\mathrm{Zn}$ concentrations in storm runoff samples exceeded the CMC. In general, the concentrations of dissolved $\mathrm{Cu}$ and $\mathrm{Zn}$ were higher in first flush than the composite samples; both were below the CMC and higher than HMTV. The median of dissolved Fe concentrations in runoff samples exceeded the CTV, as shown in Figure 4.4. The concentrations of dissolved Fe in composite samples tended to be higher than the first flush and both exceeded the CTV, as shown in Figure 4.4. 


\subsubsection{Dissolved $\mathrm{Cu}$}
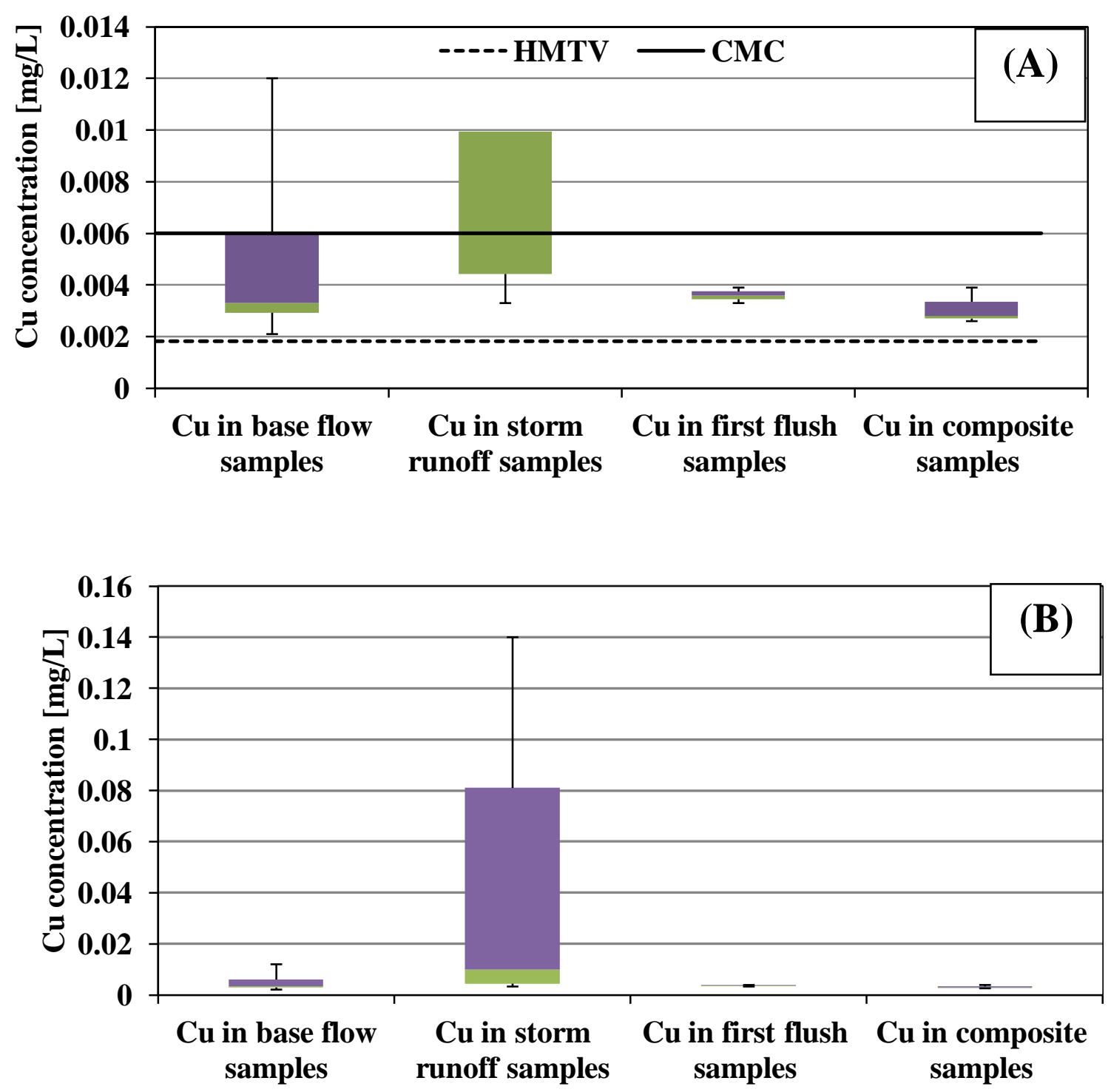

Figure 4.2 (A) HMTV, CMC and statistical parameters of dissolved $\mathrm{Cu}$ concentrations $[\mathrm{mg} / \mathrm{L}]$ in base flow, storm runoff, first flush and composite samples at site 1 of Porirua Stream. Note that the $75^{\text {th }}$ percentile and maximum of storm runoff samples are excluded from Figure 4.2 (A) but are shown in Figure 4.2 (B) (0.081 and $0.14 \mathrm{mg} / \mathrm{L}$ respectively). 


\subsubsection{Dissolved Zn}

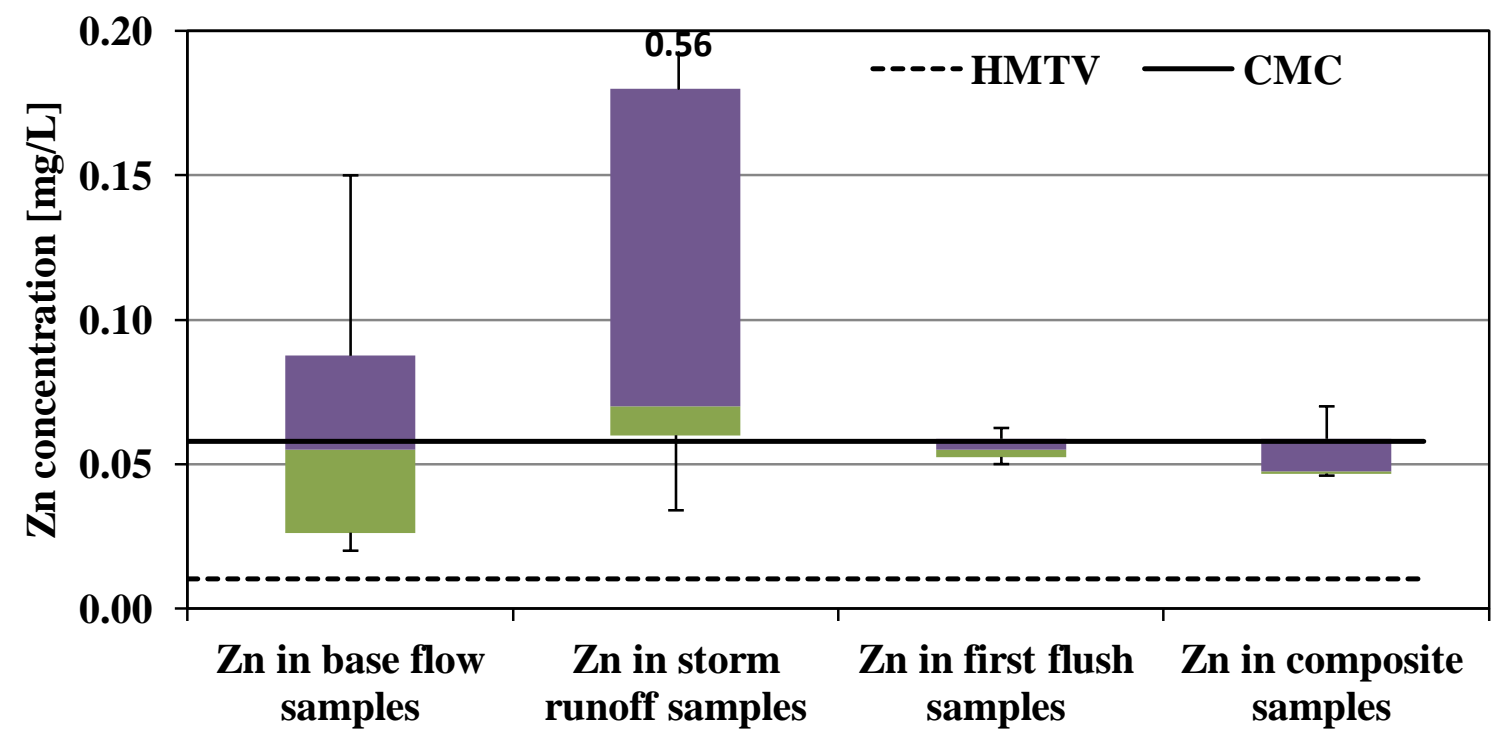

Figure 4.3 HMTV, CMC and statistical parameters of dissolved Zn concentrations $[\mathrm{mg} / \mathrm{L}]$ in base flow, storm runoff, first flush and composite samples at site 1 of Porirua Stream.

\subsubsection{Dissolved Fe}

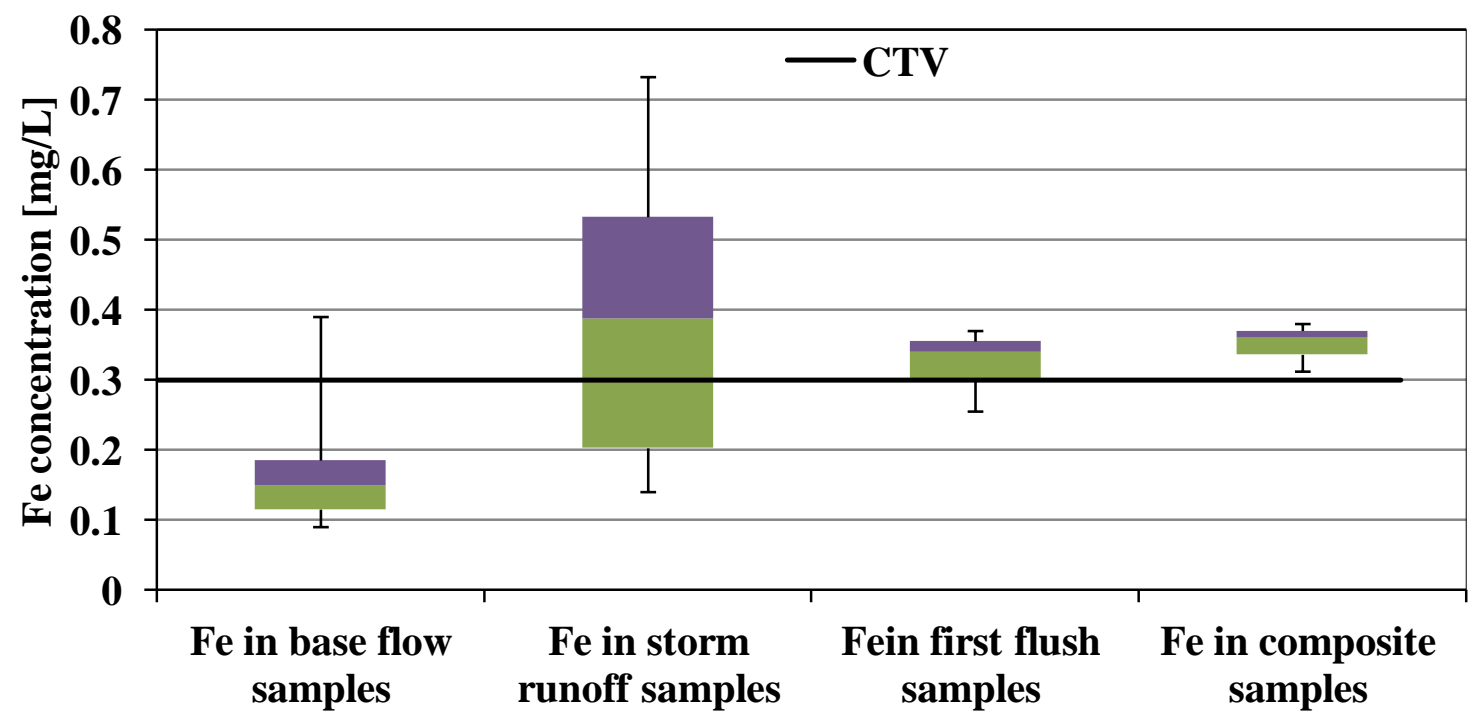

Figure 4.4 CTV and statistical parameters of dissolved Fe concentrations $[\mathrm{mg} / \mathrm{L}]$ in base flow, storm runoff, first flush and composite samples at site 1 of Porirua Stream. 


\subsubsection{Site 2 Data}

A total of 20 base flow and 10 storm runoff samples were collected at this site. It was noted that the median of dissolved $\mathrm{Cu}$ and $\mathrm{Zn}$ concentrations in base flow and storm runoff samples at sites 2 and 3 were lower in comparison to those for site1, but that they exceeded the HMTVs (refer to Figures 4.2 and 4.3 for site 1 and Figures 4.5 and 4.6 for site 2 and Figures 4.8 and 4.9 for site 3 ).

\subsubsection{Dissolved $\mathrm{Cu}$}

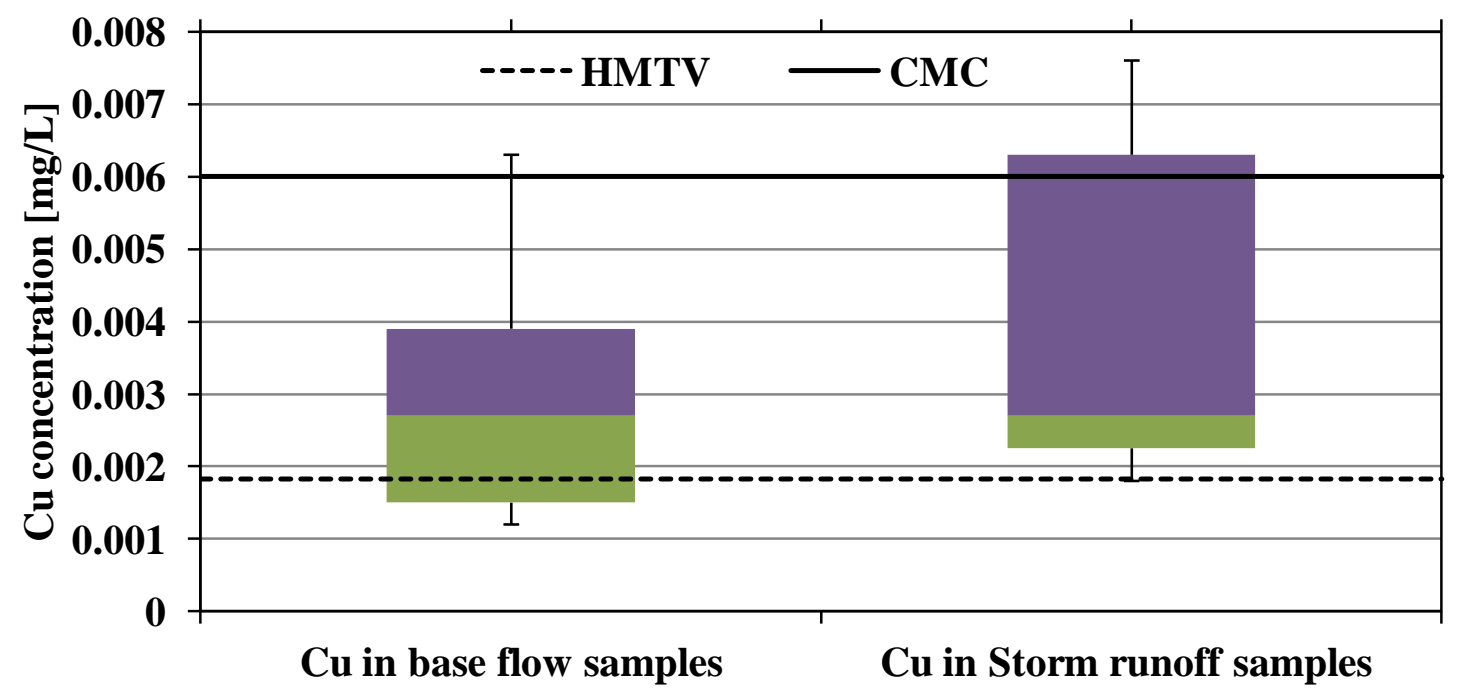

Figure 4.5 HMTV, CMC and statistical parameters of dissolved $\mathrm{Cu}$ concentrations $[\mathrm{mg} / \mathrm{L}]$ in base flow and storm runoff samples at site 2 of Porirua Stream. 


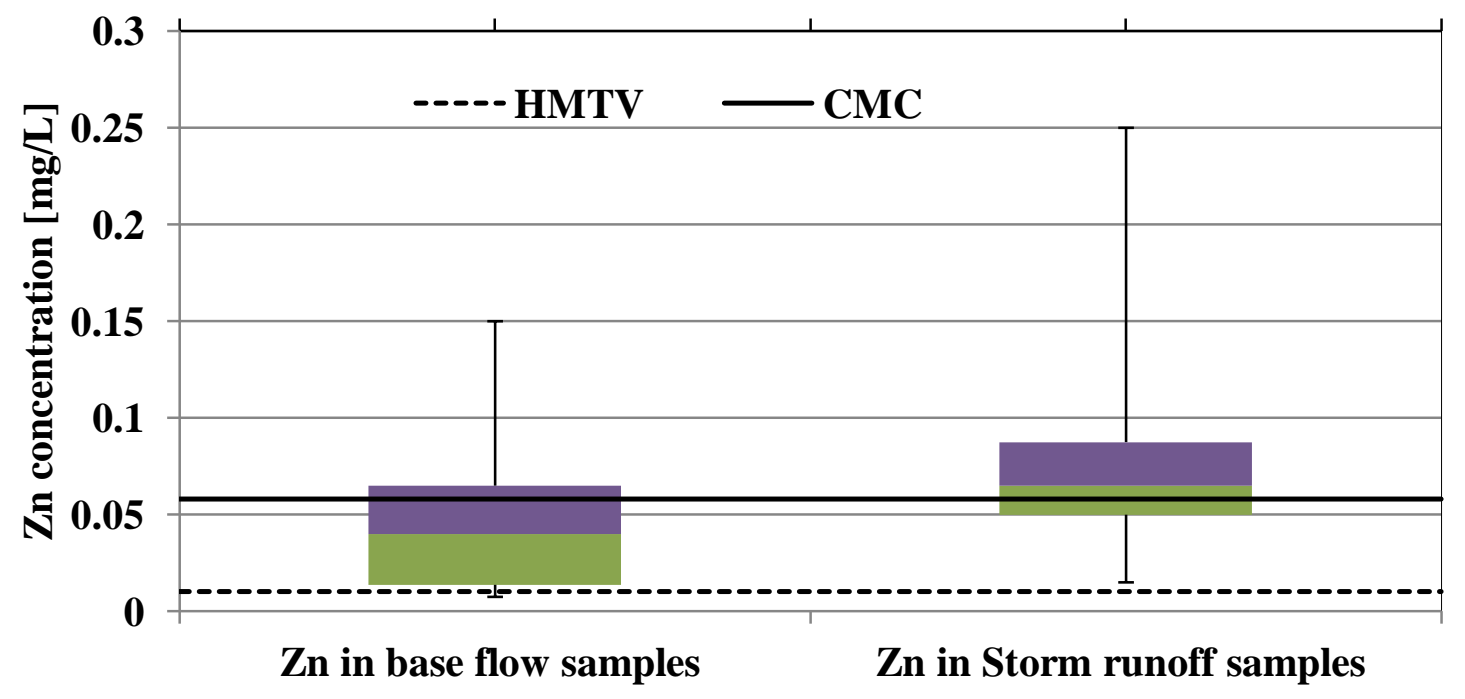

Figure 4.6 HMTV, CMC and statistical parameters of dissolved Zn concentrations $[\mathrm{mg} / \mathrm{L}]$ in base flow and storm runoff samples at site 2 of Porirua Stream.

\subsubsection{Dissolved Fe}

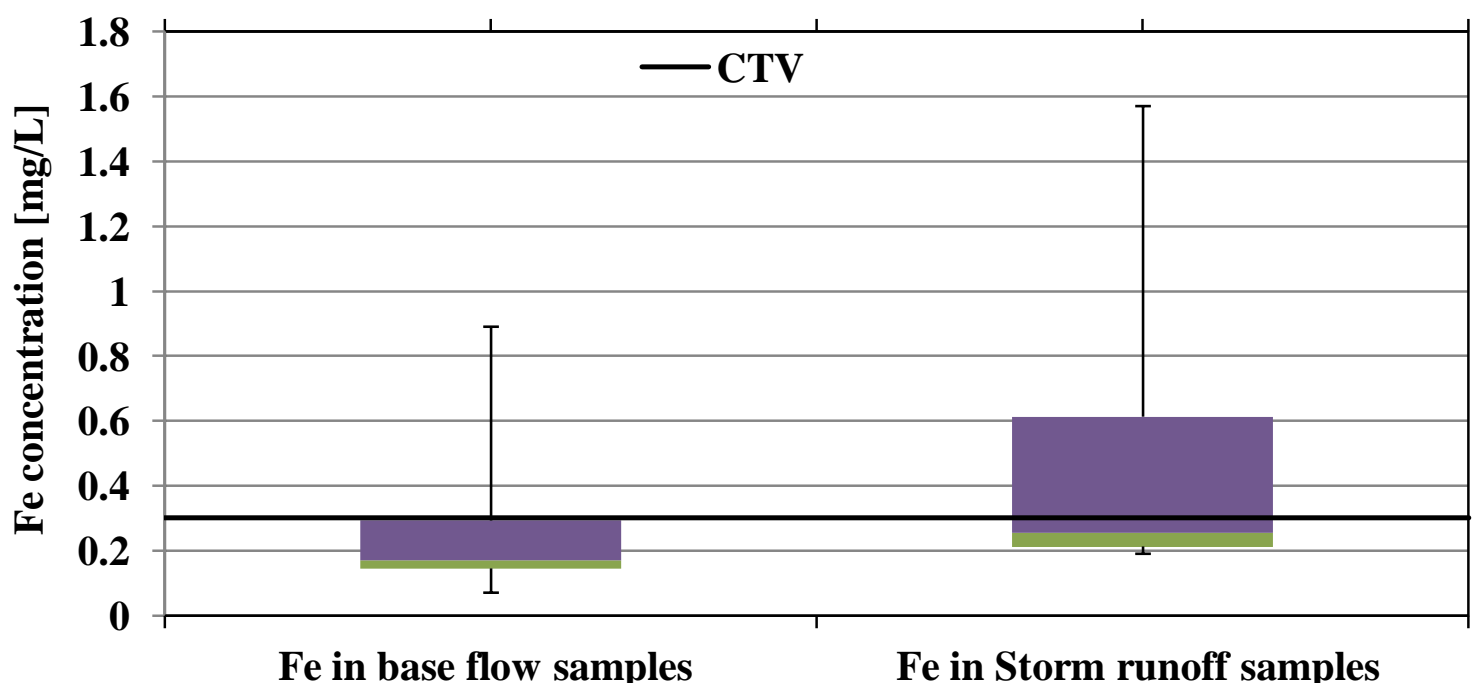

Figure 4.7 CTV and statistical parameters of dissolved Fe concentrations [mg/L] in base flow and storm runoff samples at site 2 of Porirua Stream. 


\subsubsection{Site 3 Data}

A total of 22 base flow and 8 storm runoff samples were collected at site 3 .

\subsubsection{Dissolved Cu}

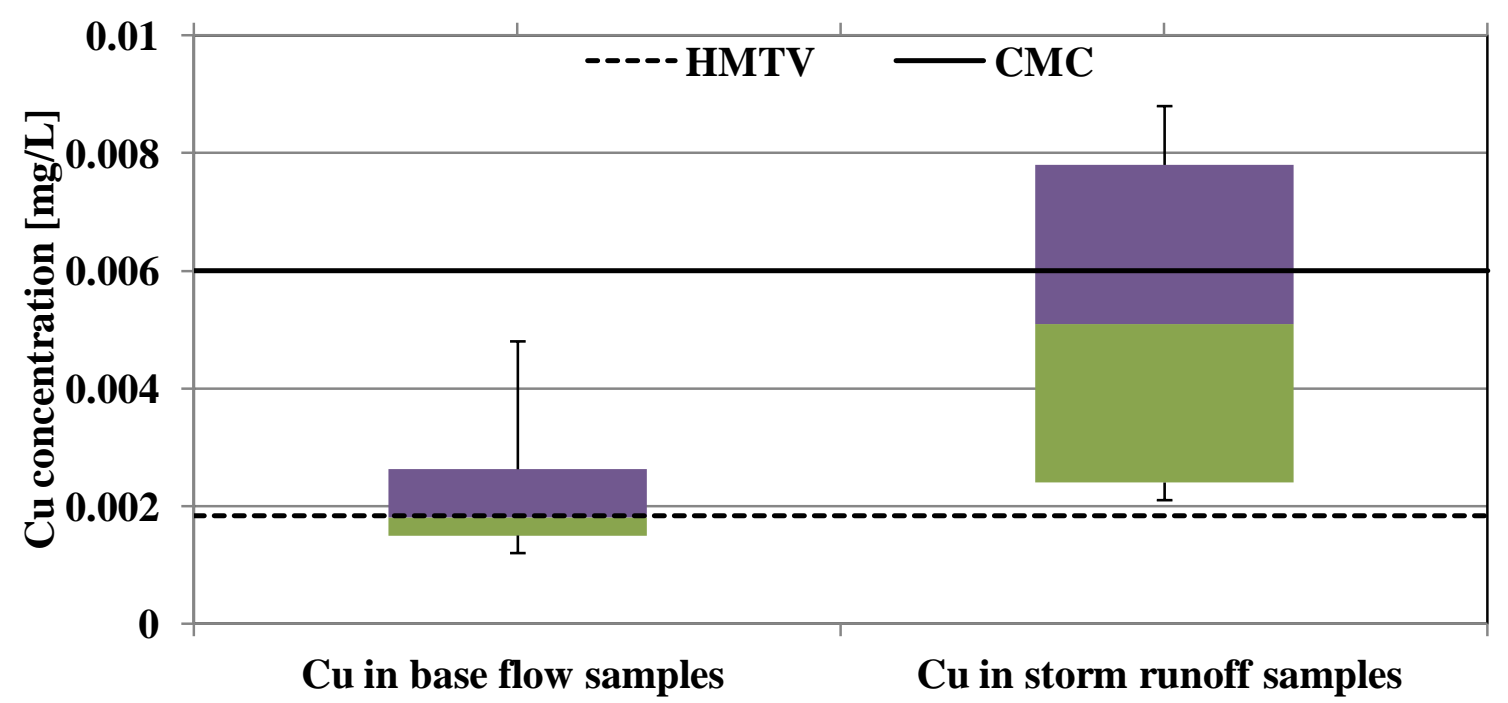

Figure 4.8 HMTV, CMC and statistical parameters of dissolved $\mathrm{Cu}$ concentrations $[\mathrm{mg} / \mathrm{L}]$ in base flow and storm runoff samples at site 3 of Porirua Stream. 


\subsubsection{Dissolved Zn}

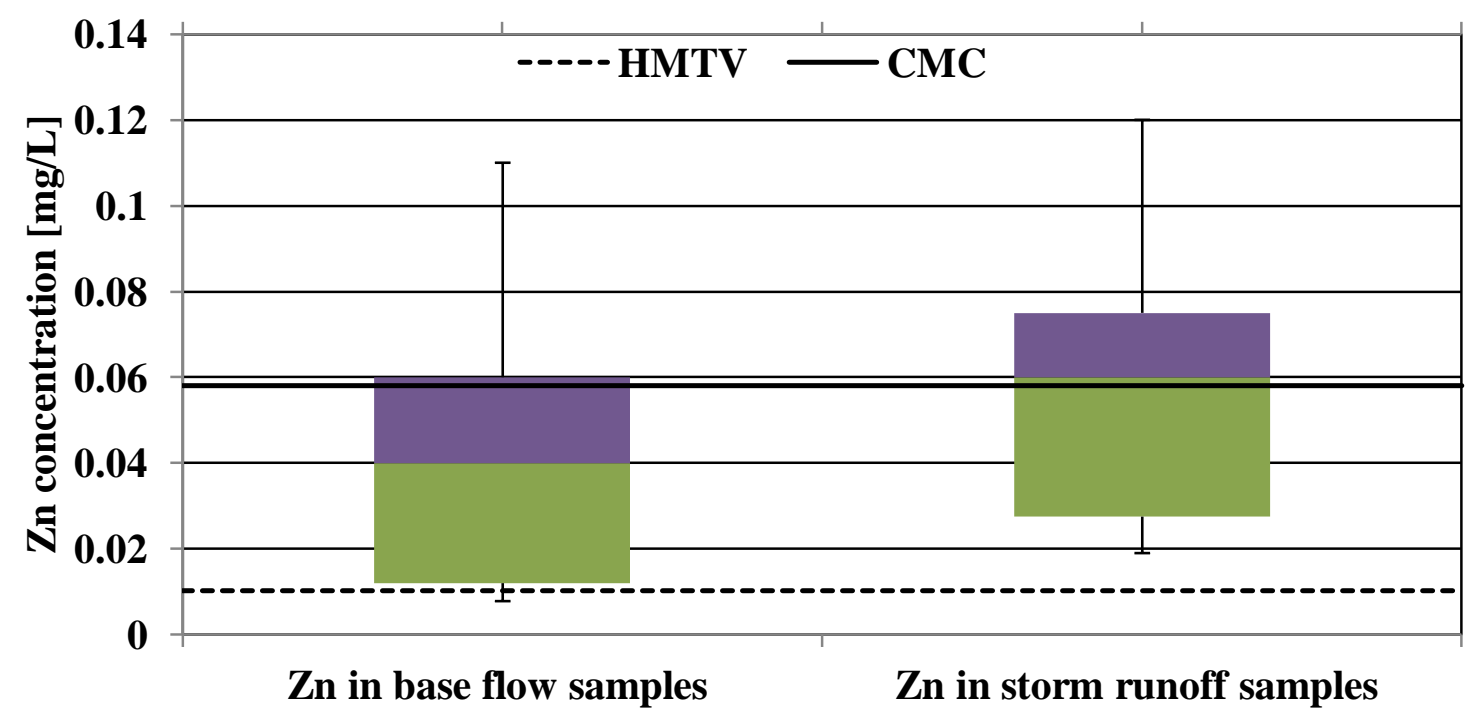

Figure 4.9 HMTV, CMC and statistical parameters of dissolved Zn concentrations $[\mathrm{mg} / \mathrm{L}]$ in base flow and storm runoff samples at site 3 of Porirua Stream.

\subsubsection{Dissolved Fe}

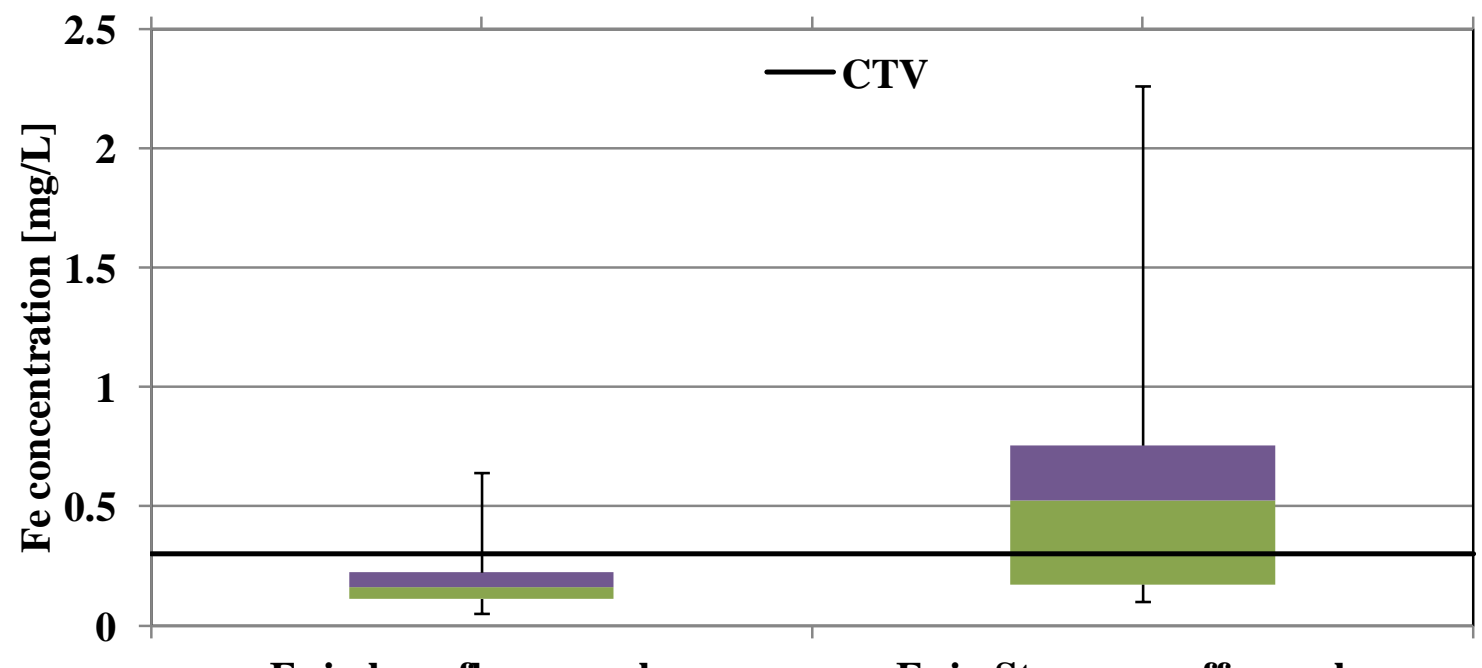

Fe in base flow samples

Fe in Storm runoff samples

Figure 4.10 CTV and statistical parameters of dissolved Fe concentrations $[\mathrm{mg} / \mathrm{L}]$ in base flow and storm runoff samples at site 3 of Porirua Stream. 


\subsubsection{Site 4 Data}

A total of 22 base flow and 10 storm runoff samples were obtained at this site. One storm runoff event was observed for first flush, which gave 1 first flush and one composite sample. The data for first flush monitoring is shown in Appendix 1, in site 4 data.

\subsubsection{Dissolved Cu}

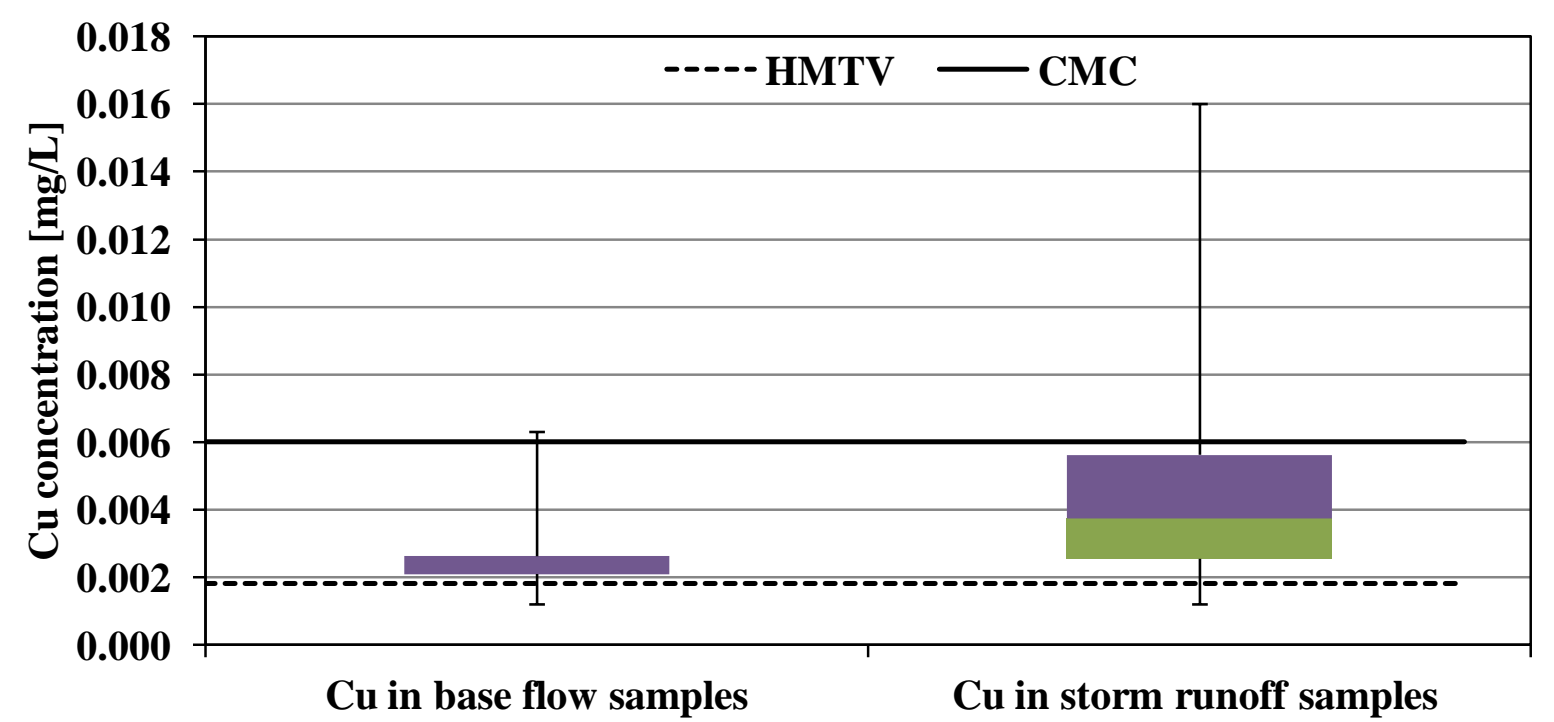

Figure 4.11 HMTV, CMC and statistical parameters of dissolved $\mathrm{Cu}$ concentrations $[\mathrm{mg} / \mathrm{L}]$ in base flow and storm runoff samples at site 4 of Porirua Stream. 


\subsubsection{Dissolved Zn}

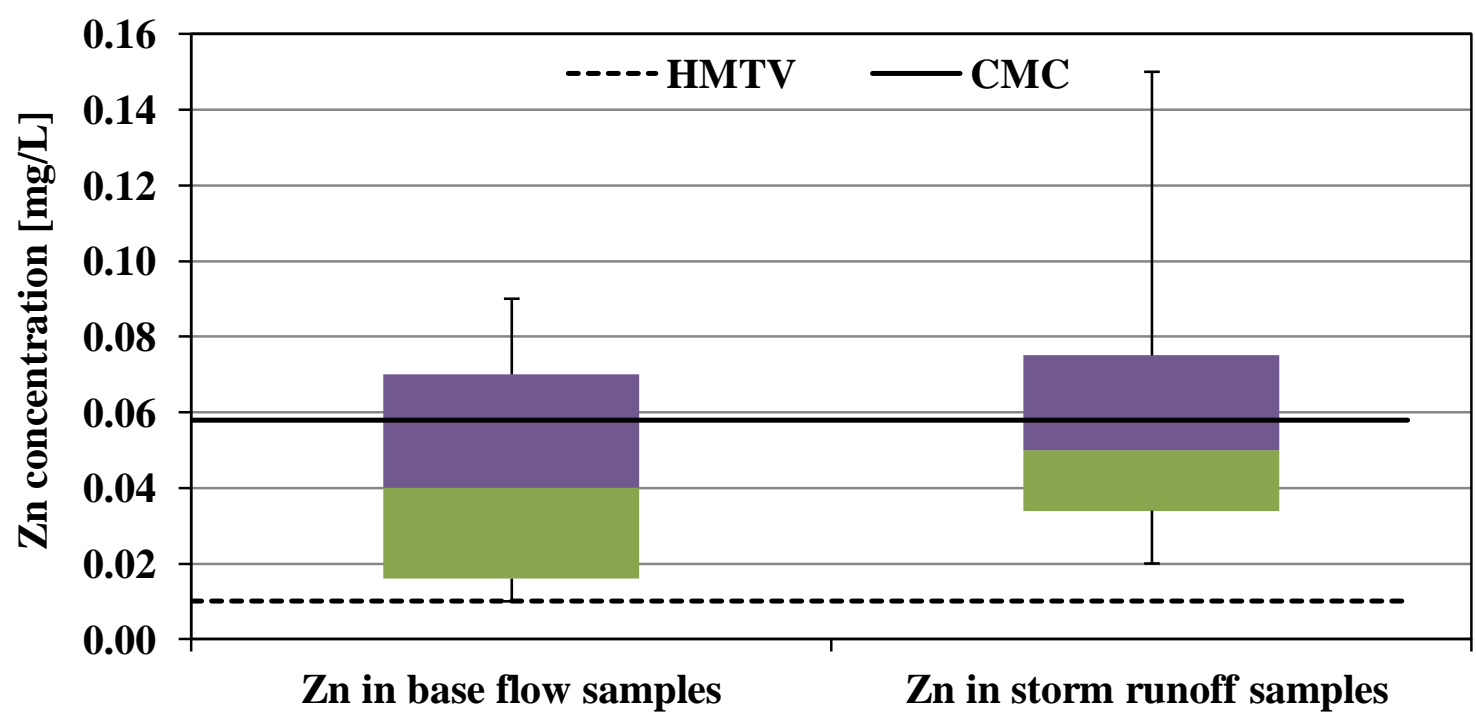

Figure 4.12 HMTV, CMC and statistical parameters of dissolved Zn concentrations $[\mathrm{mg} / \mathrm{L}]$ in base flow and storm runoff samples at site 4 of Porirua Stream.

\subsubsection{Dissolved Fe}

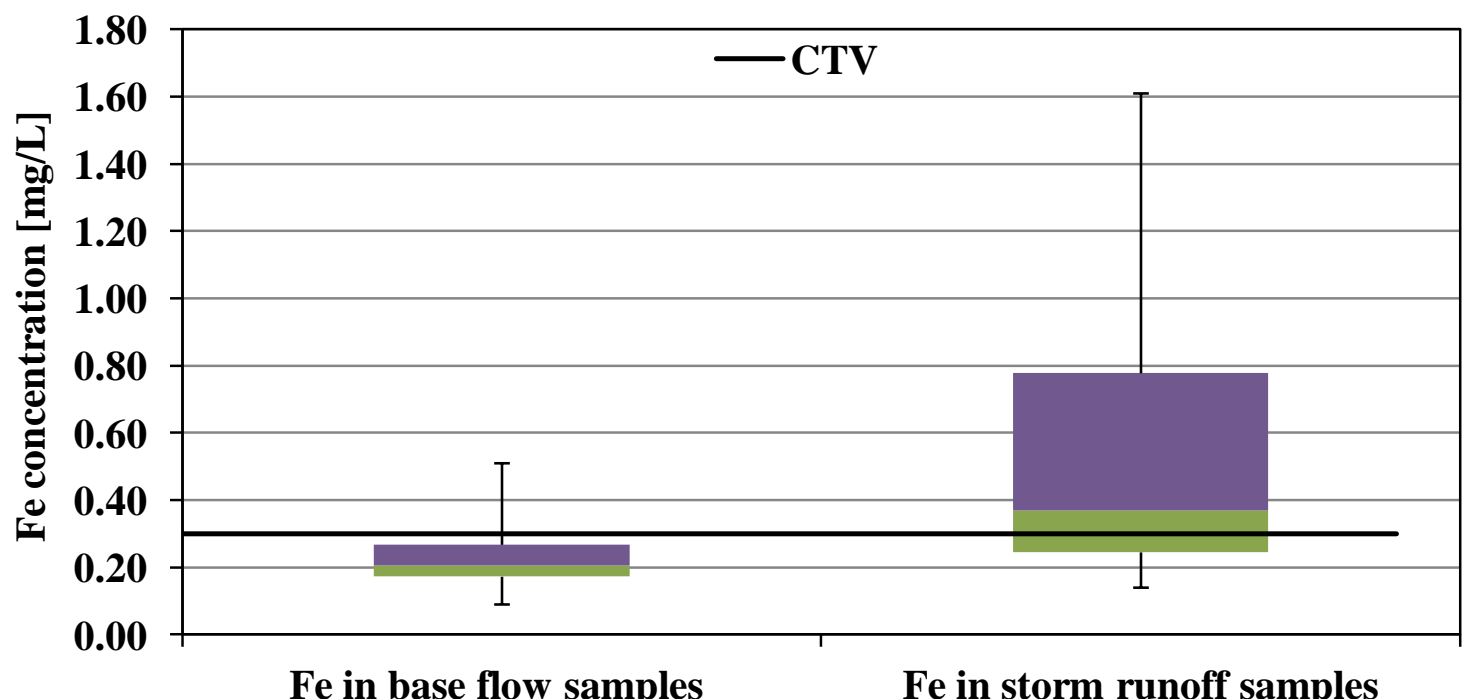

Figure 4.13 CTV and statistical parameters of dissolved Fe concentrations [mg/L] in base flow and storm runoff samples at site 4 of Porirua Stream. 


\subsubsection{Site 5 Data}

A total of 21 base flow and 10 storm runoff samples were collected and analysed for this site. One storm runoff event was monitored for first flush which resulted in one first flush and one composite sample. First flush monitoring data is reported in Appendix 1 , in site 5 data. Notably, this site is the only site that the medians of dissolved Fe exceeded the CTV in base flow samples, this is discussed further in Section 4.2.

\subsubsection{Dissolved $\mathrm{Cu}$}

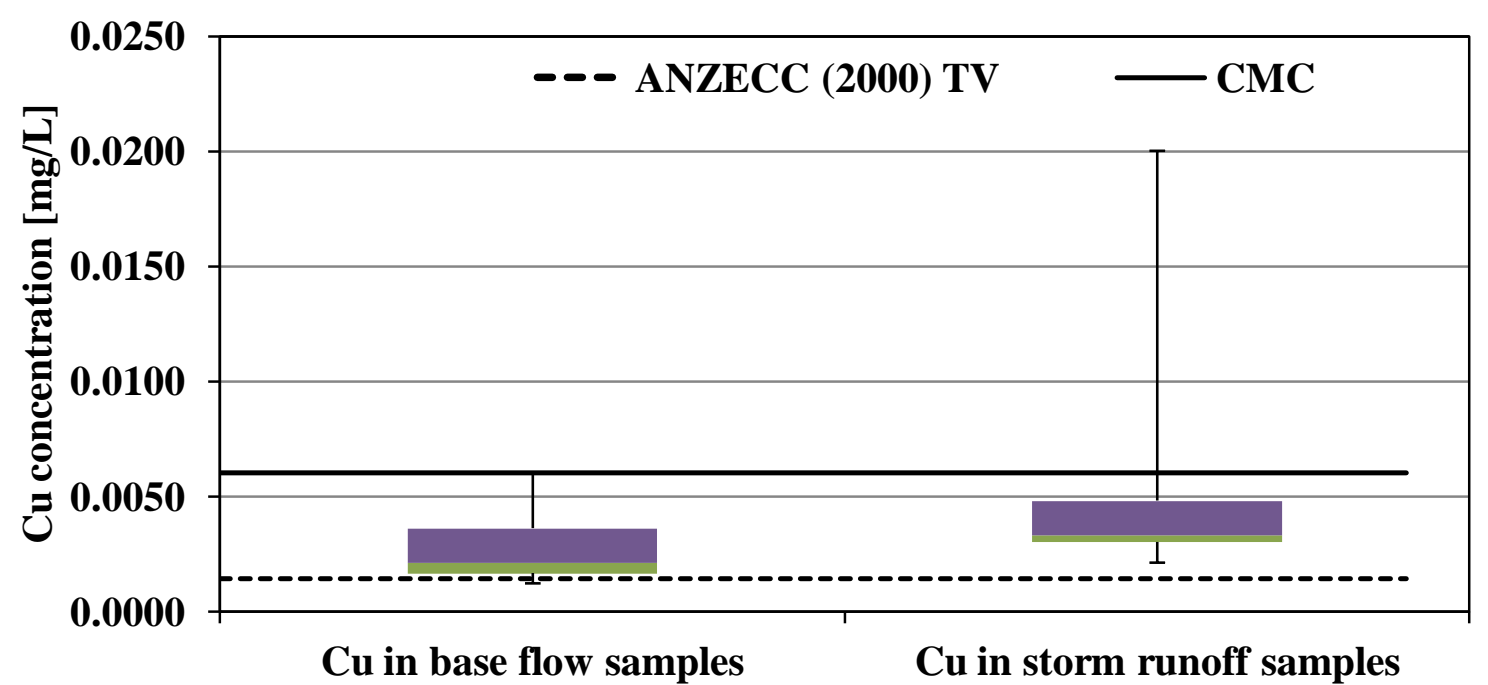

Figure 4.14 ANZECC (2000) TV, CMC and statistical parameters of dissolved $\mathrm{Cu}$ concentrations $[\mathrm{mg} / \mathrm{L}]$ in base flow and storm runoff samples at site 5 of Kenepuru Stream. 


\subsubsection{Dissolved Zn}

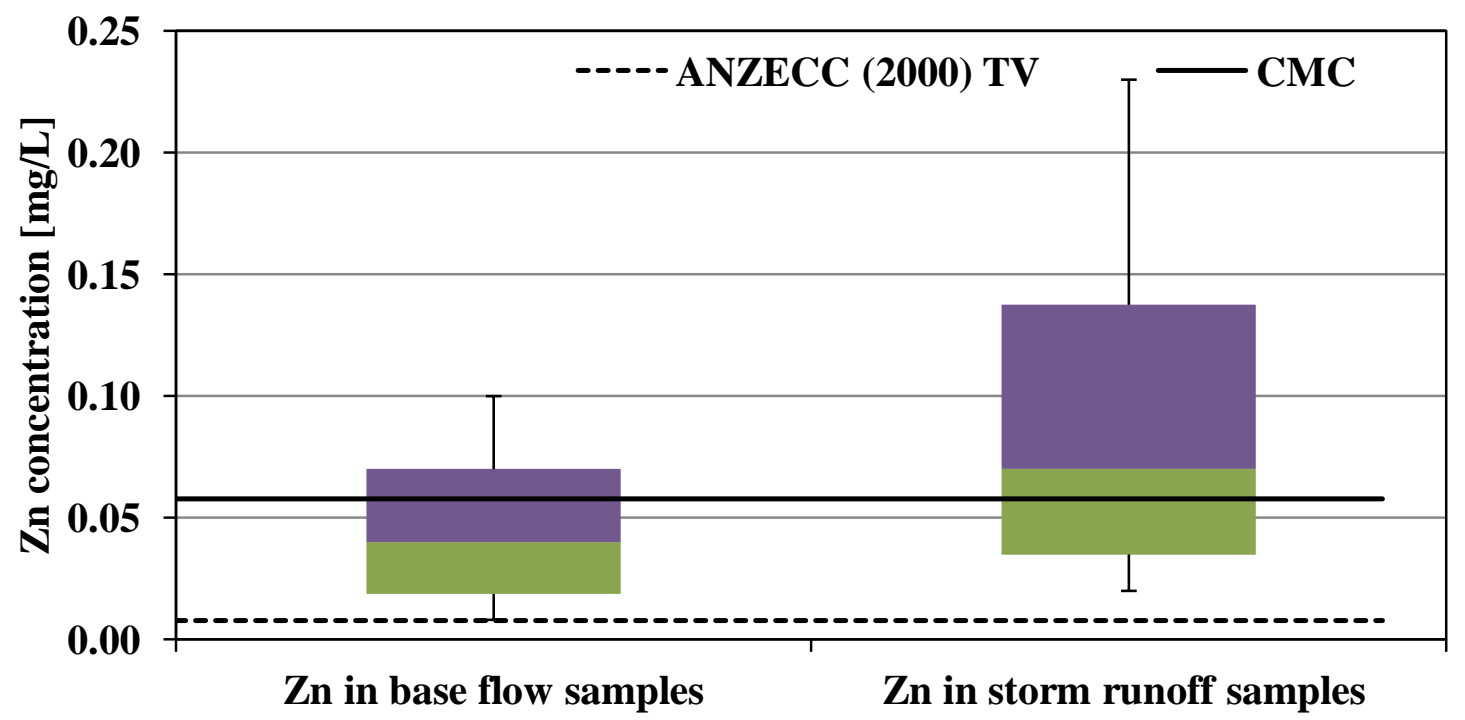

Figure 4.15 ANZECC (2000) TV, CMC and statistical parameters of dissolved Zn concentrations $[\mathrm{mg} / \mathrm{L}]$ in base flow and storm runoff samples at site 5 Kenepuru Stream.

\subsubsection{Dissolved Fe}

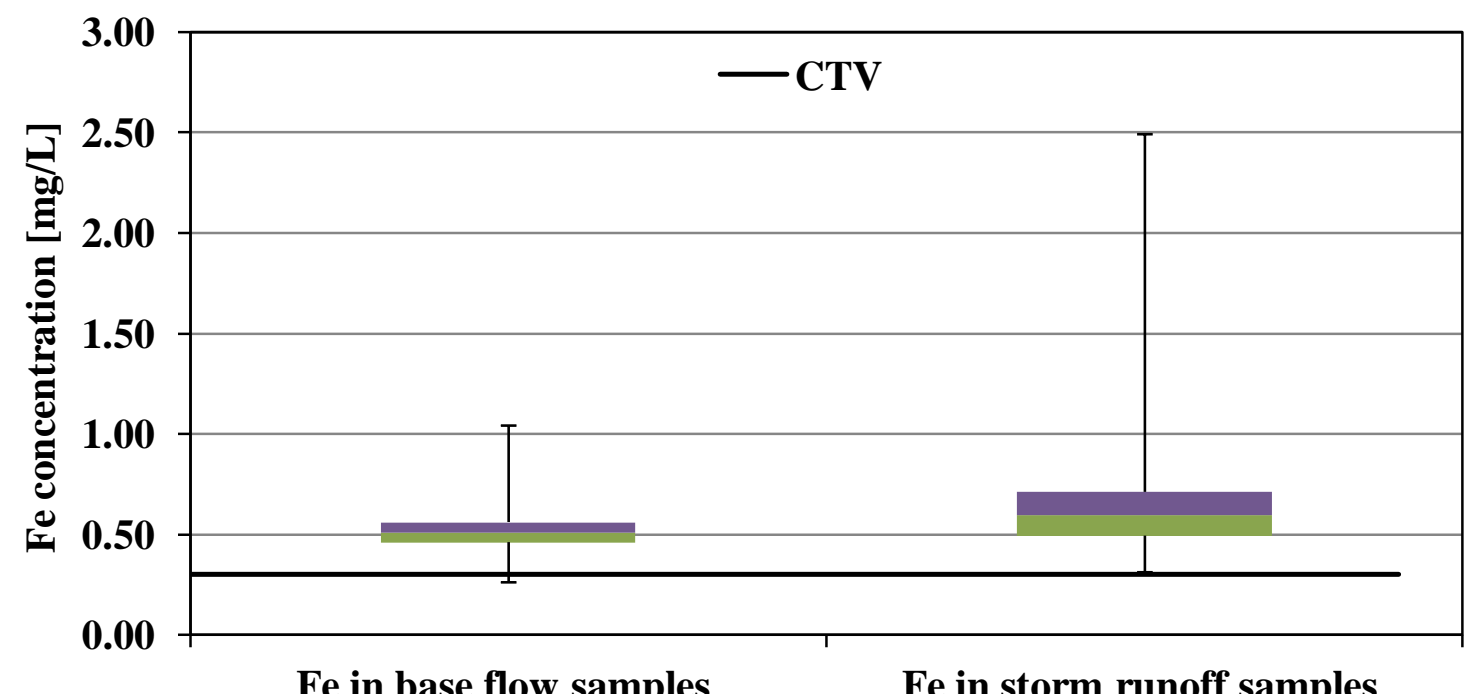

Figure 4.16 CTV and statistical parameters of dissolved Fe concentrations [mg/L] in base flow and storm runoff samples at site 5 of Kenepuru Stream. 


\subsubsection{Site 6 Data}

A total of 20 base flow and 9 storm runoff samples were obtained at this site.

\subsubsection{Dissolved Cu}

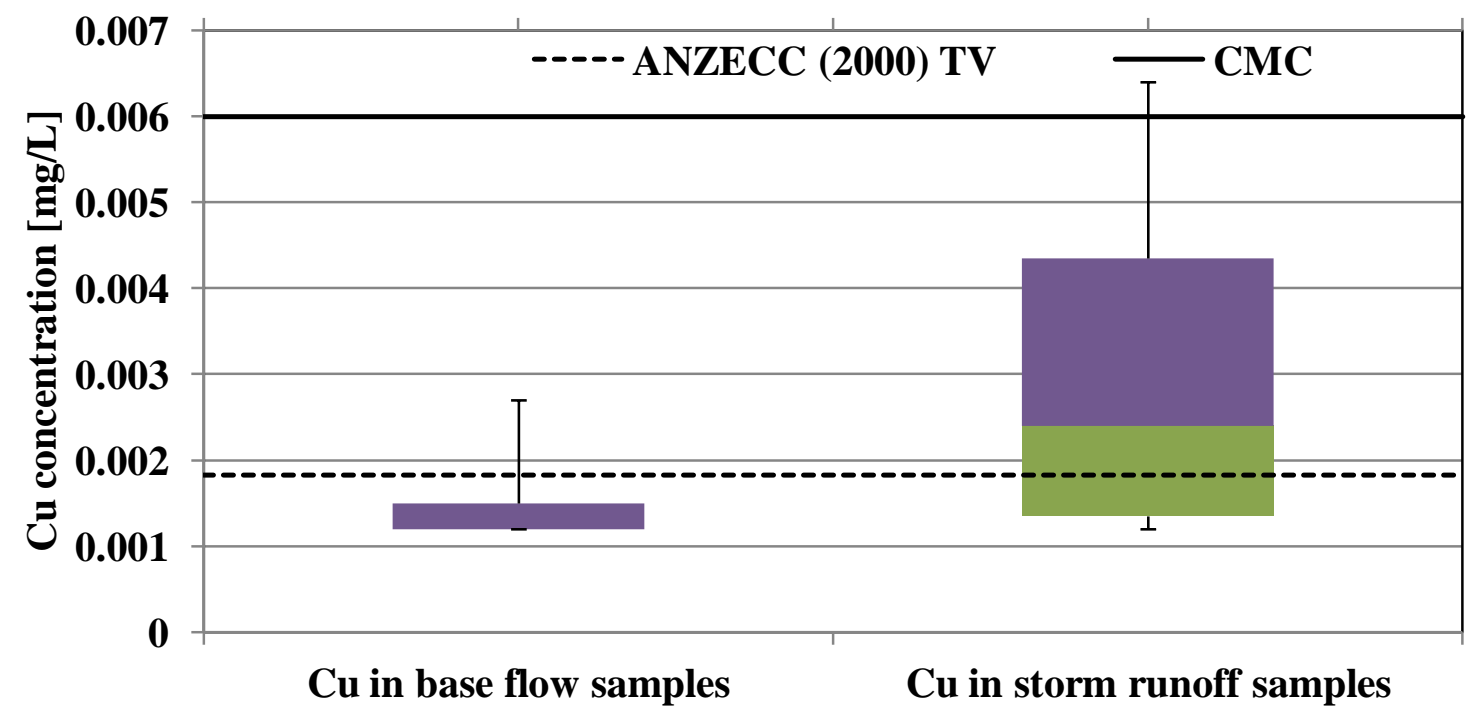

Figure 4.17 ANZECC (2000) TV, CMC and statistical parameters of dissolved $\mathrm{Cu}$ concentrations $[\mathrm{mg} / \mathrm{L}]$ in base flow and storm runoff samples collected from site 6 of Takapu Stream. 


\subsubsection{Dissolved Zn}

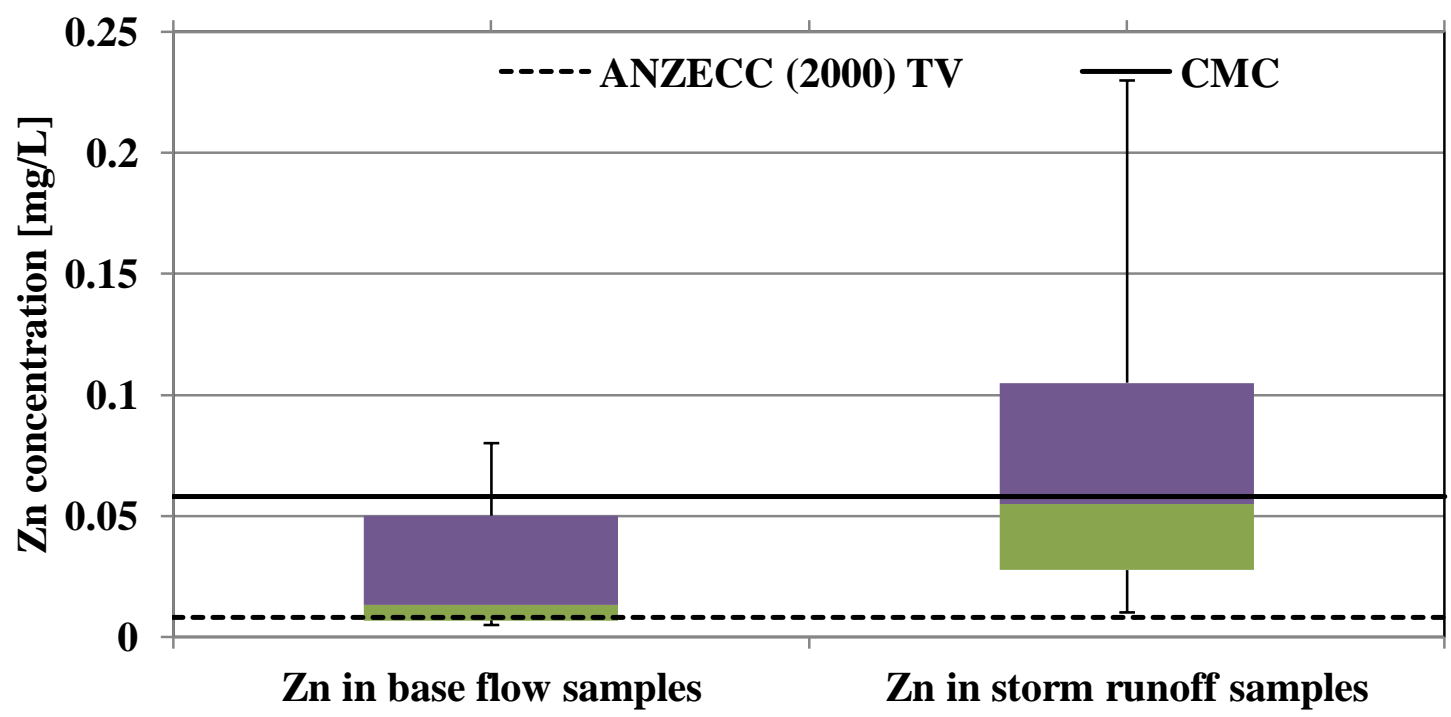

Figure 4.18 ANZECC (2000) TV, CM and statistical parameters of dissolved Zn concentrations $[\mathrm{mg} / \mathrm{L}]$ in base flow and storm runoff samples obtained from site 6 of Takapu Stream.

\subsubsection{Dissolved Fe}

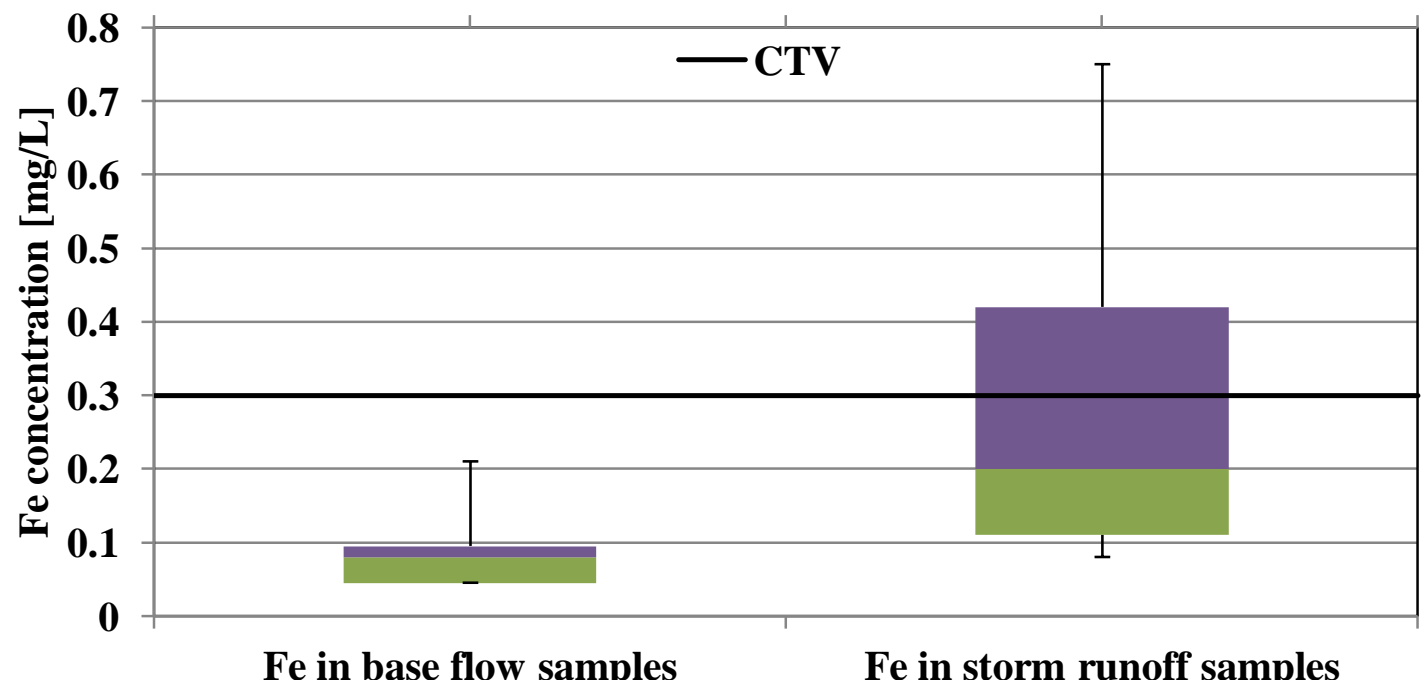

Figure 4.19 CTV and statistical parameters of dissolved Fe concentrations $[\mathrm{mg} / \mathrm{L}]$ in base flow and storm runoff samples for site 6 of Takapu Stream. 


\subsubsection{Site 7 Data}

A total of 20 base flow and 9 storm runoff samples were collected at this site.

\subsubsection{Dissolved $\mathrm{Cu}$}

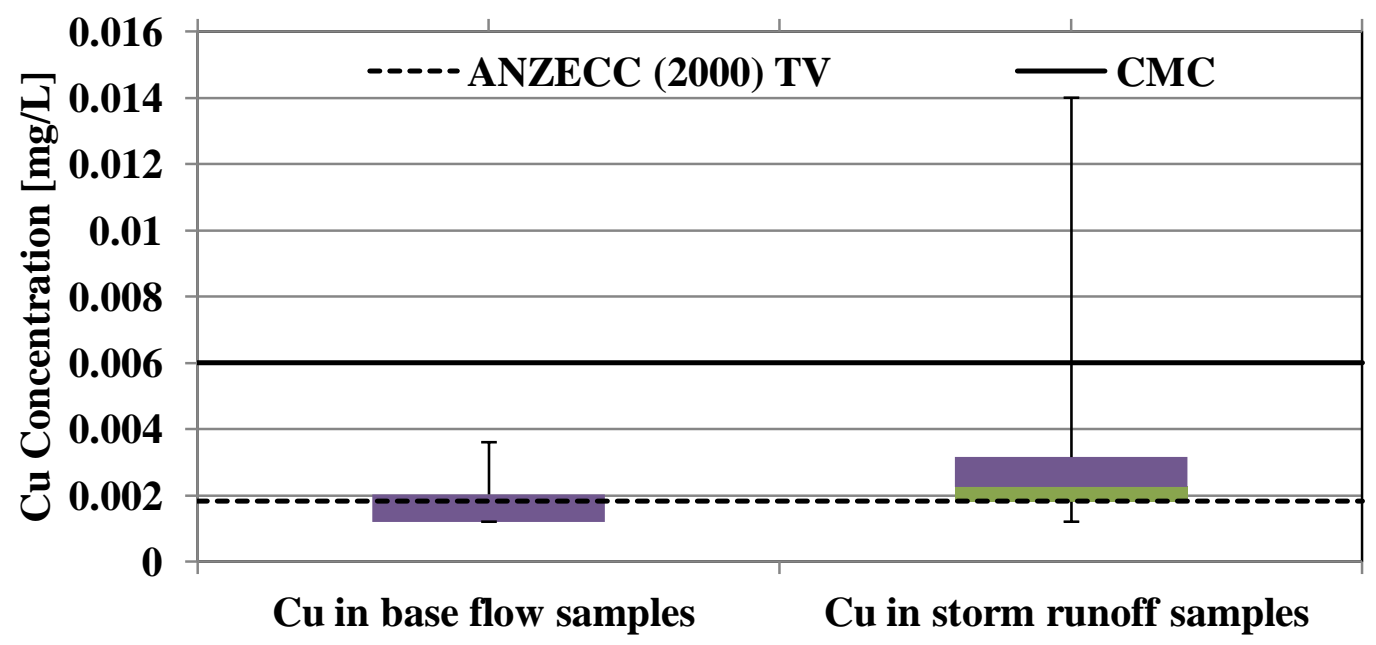

Figure 4.20 ANZECC (2000) TV, CMC and statistical parameters of dissolved $\mathrm{Cu}$ concentrations $[\mathrm{mg} / \mathrm{L}]$ in base flow and storm runoff samples collected from site 7 of Takapu Stream. 


\subsubsection{Dissolved Zn}

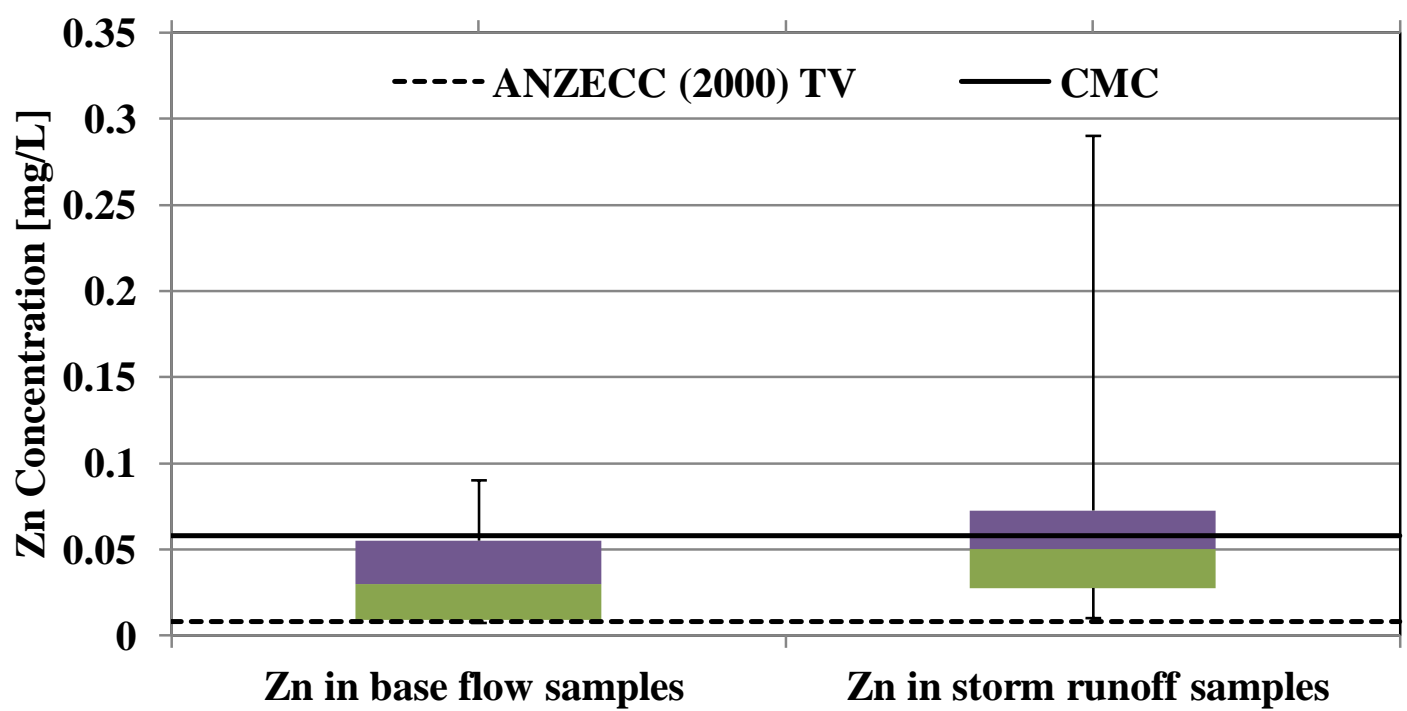

Figure 4.21 ANZECC (2000) TV, CM and statistical parameters of dissolved Zn concentrations $[\mathrm{mg} / \mathrm{L}]$ in base flow and storm runoff samples obtained from site 7 of Takapu Stream.

\subsubsection{Dissolved Fe}

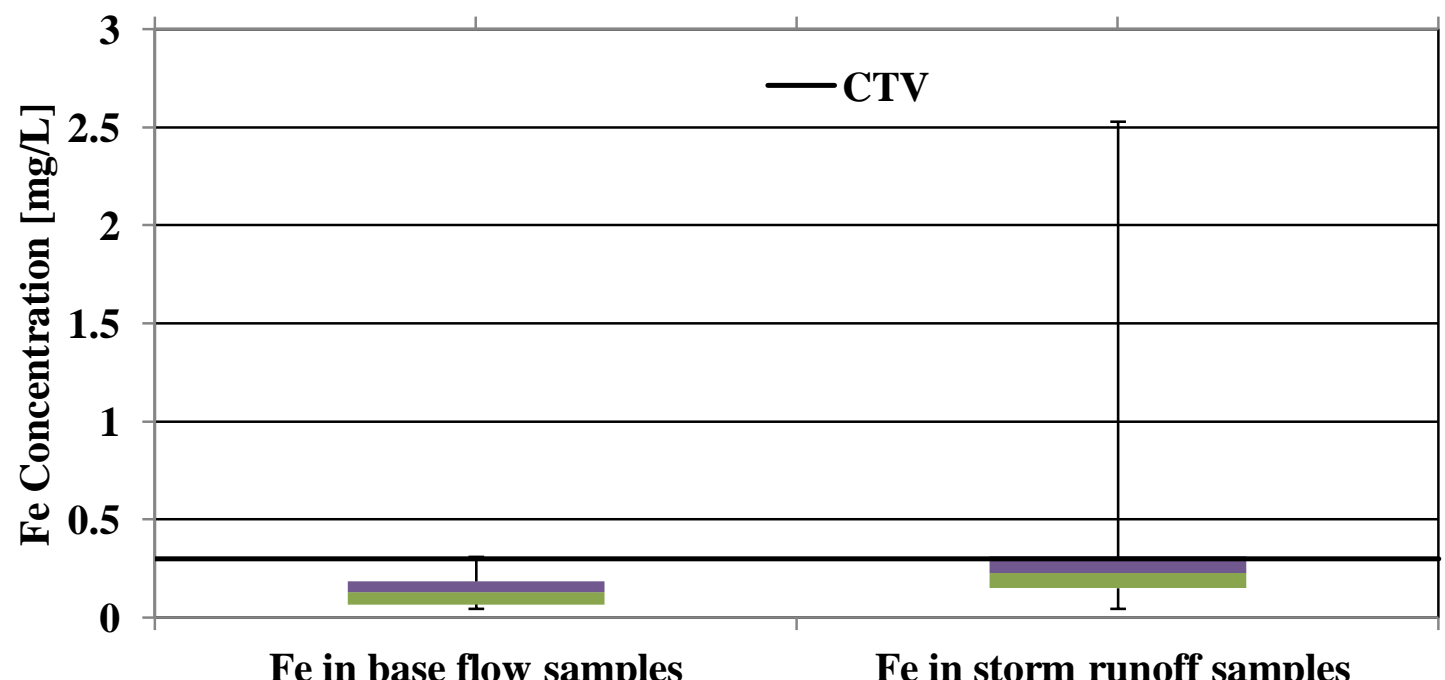

Figure 4.22 CTV and statistical parameters of dissolved Fe concentrations [mg/L] in base flow and storm runoff samples for site 7 of Takapu Stream. 


\subsubsection{Site 8 Data}

A total of 17 base flow and 5 storm runoff samples were obtained at this site. Monitoring of 2 storm runoff events for first flush were accomplished at this site, which resulted in two first flush and 2 composite samples. First flush monitoring data are presented in Appendix 1, in sites 8 and 10 data.

\subsubsection{Dissolved $\mathrm{Cu}$}

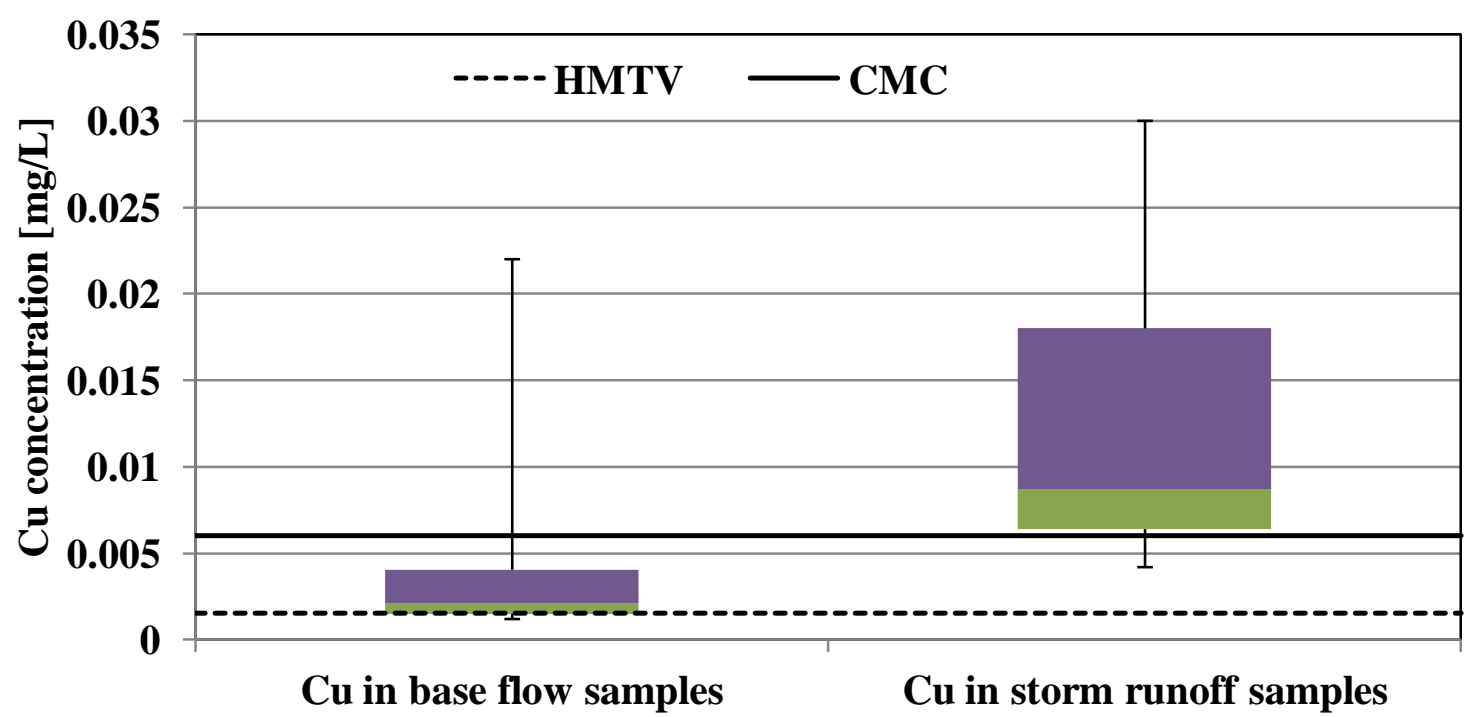

Figure 4.23 HMTV, CMC and statistical parameters of dissolved $\mathrm{Cu}$ concentrations $[\mathrm{mg} / \mathrm{L}]$ in base flow and storm runoff samples for site 8 of Karori Stream. 


\subsubsection{Dissolved Zn}

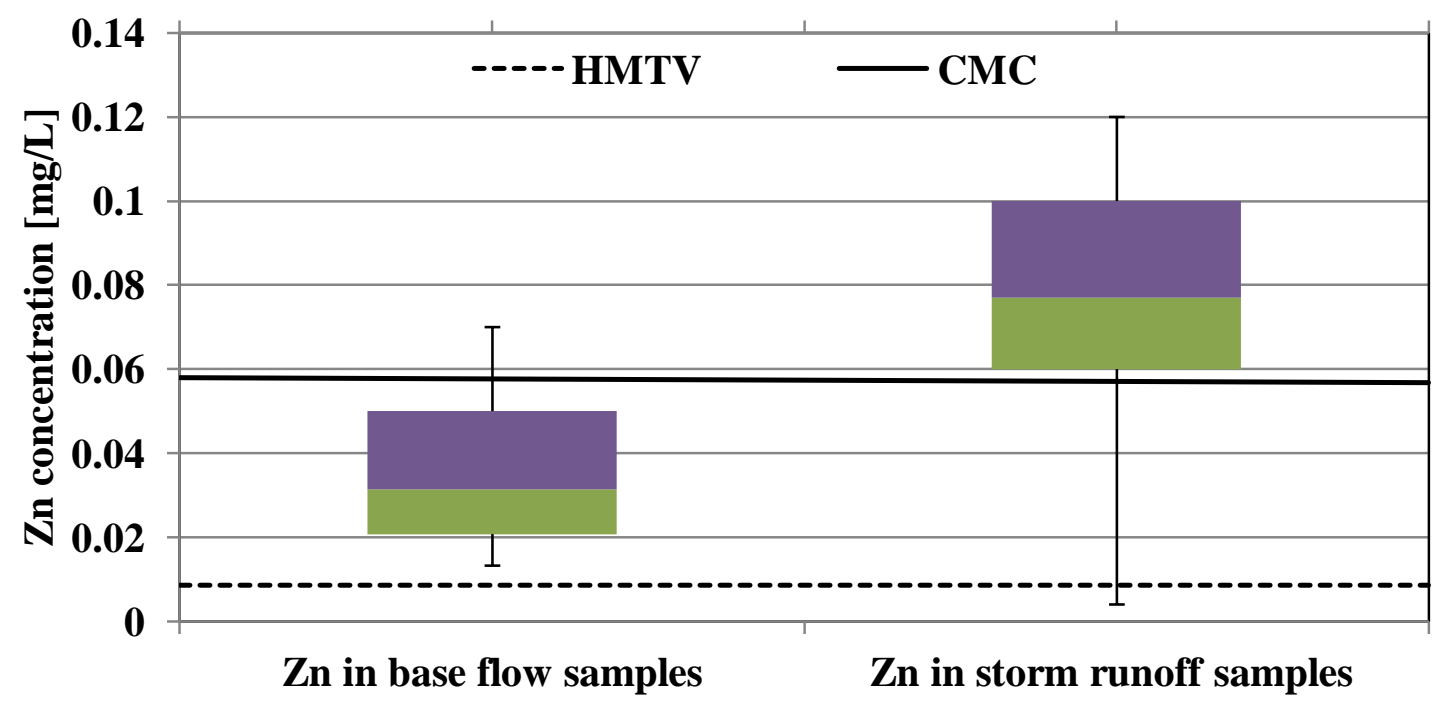

Figure 4.24 HMTV, CMC and statistical parameters of dissolved Zn concentrations $[\mathrm{mg} / \mathrm{L}]$ in base flow and storm runoff samples for site 8 of Karori Stream.

\subsubsection{Dissolved Fe}

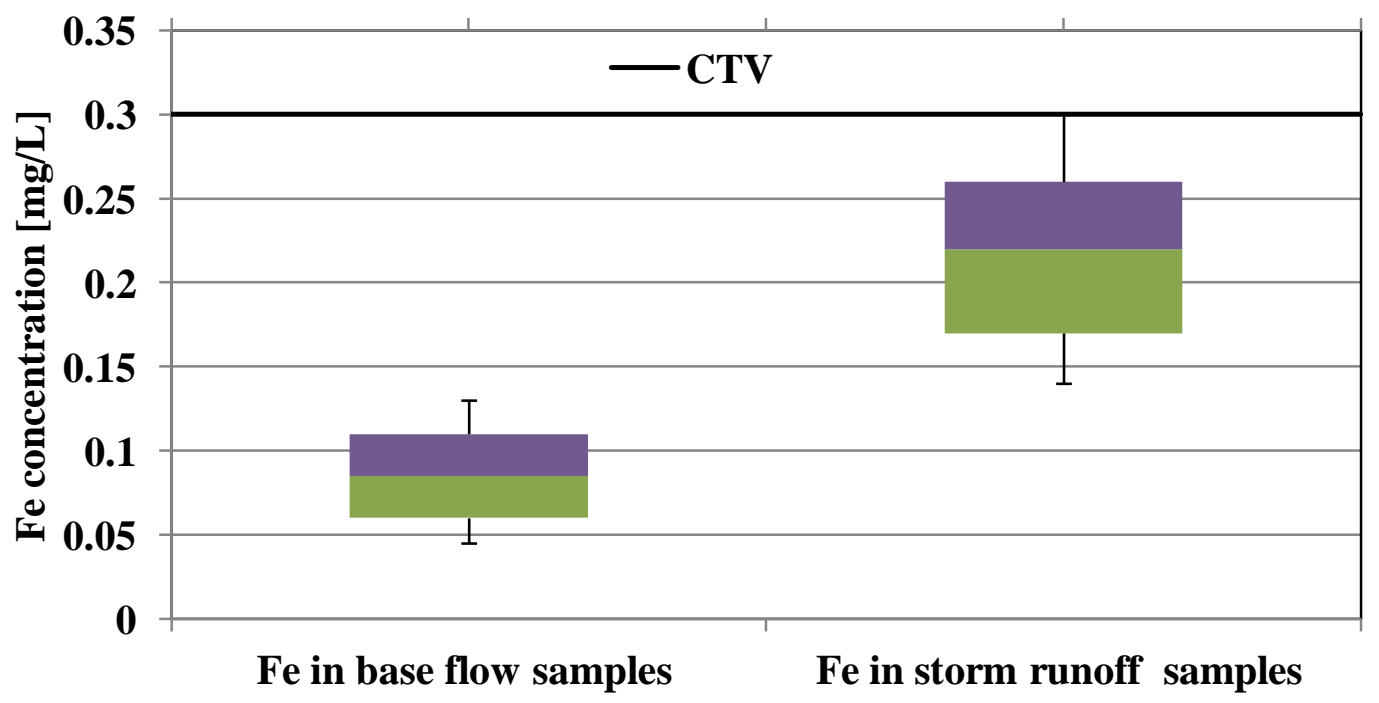

Figure 4.25 CTV and statistical parameter of dissolved Fe concentrations [mg/L] in base flow and storm runoff samples for site 8 of Karori Stream. 


\subsubsection{Site 9 Data}

A total of 17 base flow and 5 storm runoff samples were obtained at this site. Monitoring of a storm runoff event for first flush at this site was accomplished resulted in 1 first flush and 1 composite sample, presented in Appendix 1.

\subsubsection{Dissolved $\mathrm{Cu}$}

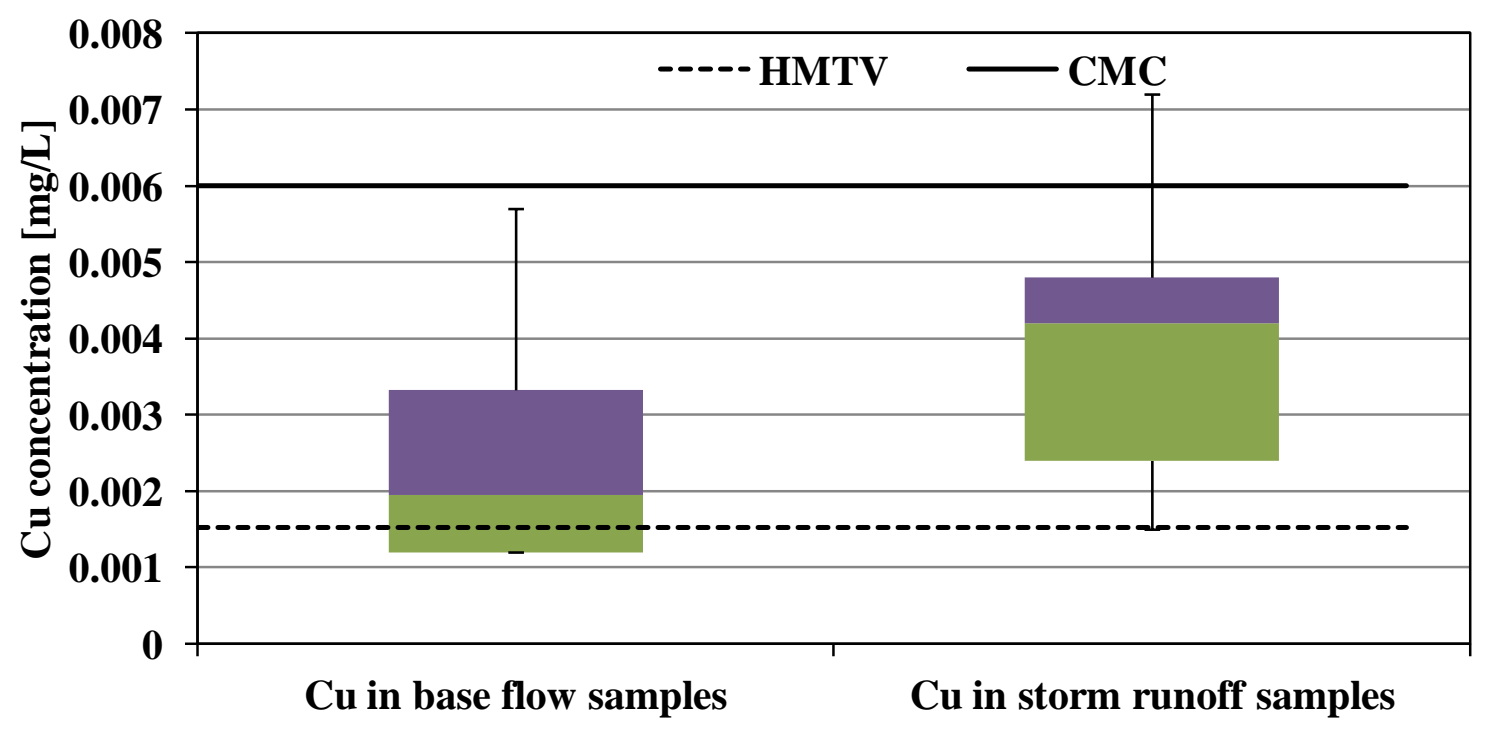

Figure 4.26 HMTV, CMC and statistical parameters of dissolved $\mathrm{Cu}$ concentrations $[\mathrm{mg} / \mathrm{L}]$ at site 9 . 


\subsubsection{Dissolved Zn}

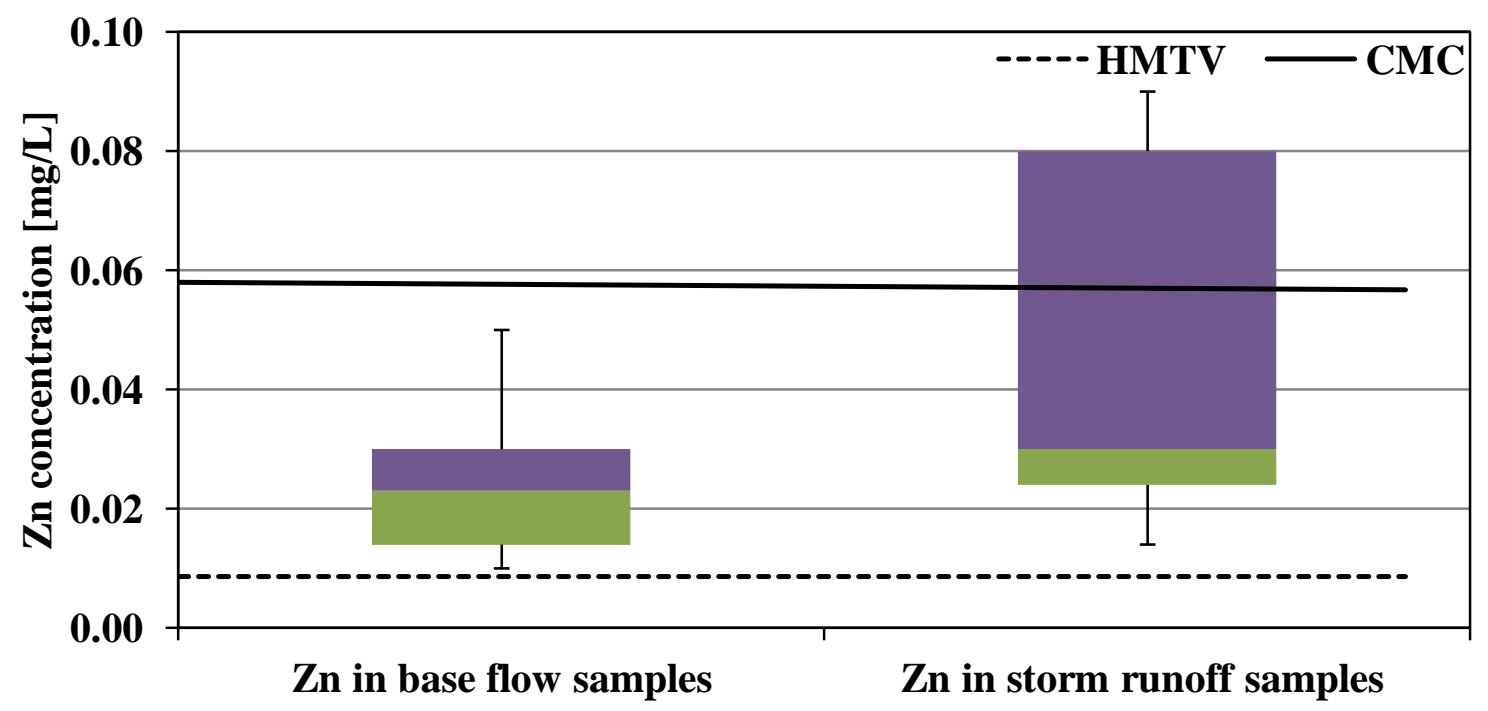

Figure 4.27 HMTV, CMC and statistical parameters of dissolved Zn concentrations $[\mathrm{mg} / \mathrm{L}]$ at site 9 .

\subsubsection{Dissolved Fe}

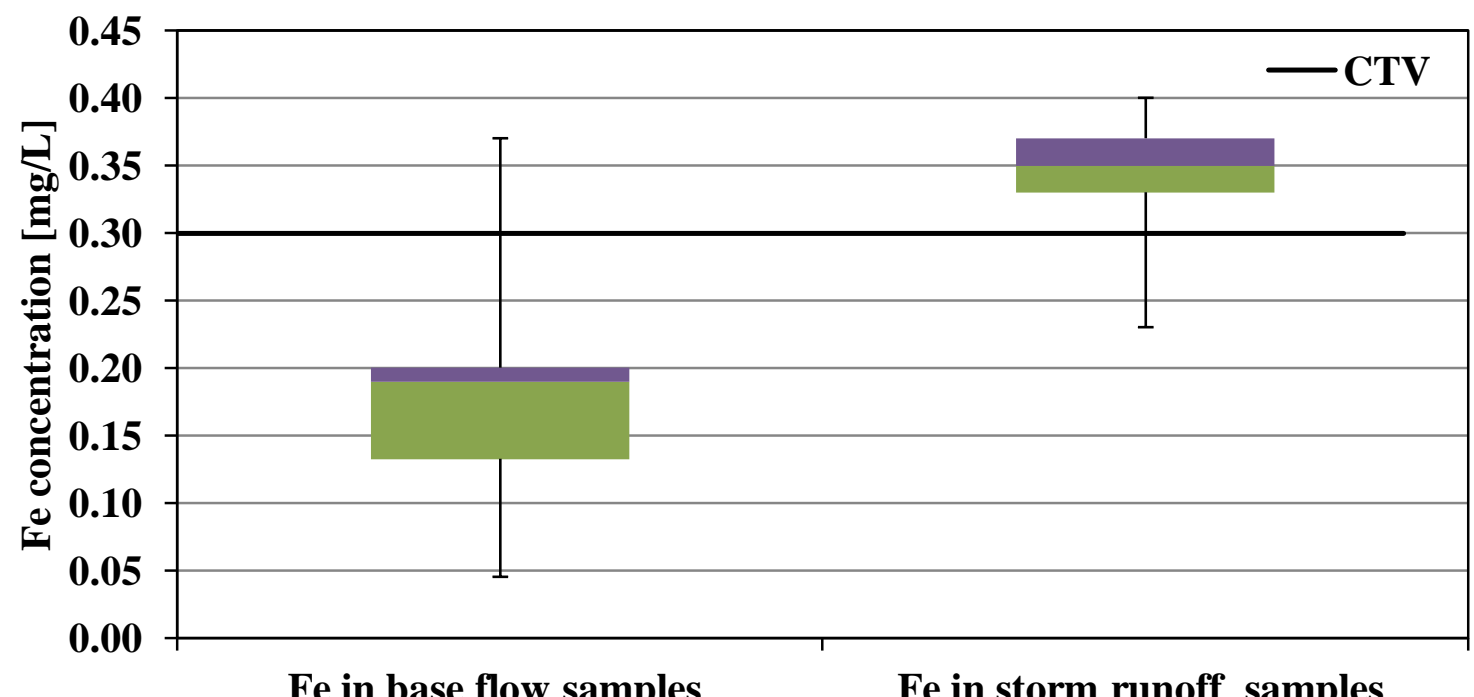

Figure 4.28 CTV and statistical parameters of dissolved Fe concentrations [mg/L] at site 9. 


\subsubsection{Site 10 Data}

A total of 17 base flow and 5 storm runoff samples were obtained at site 10 .

\subsubsection{Dissolved Cu}

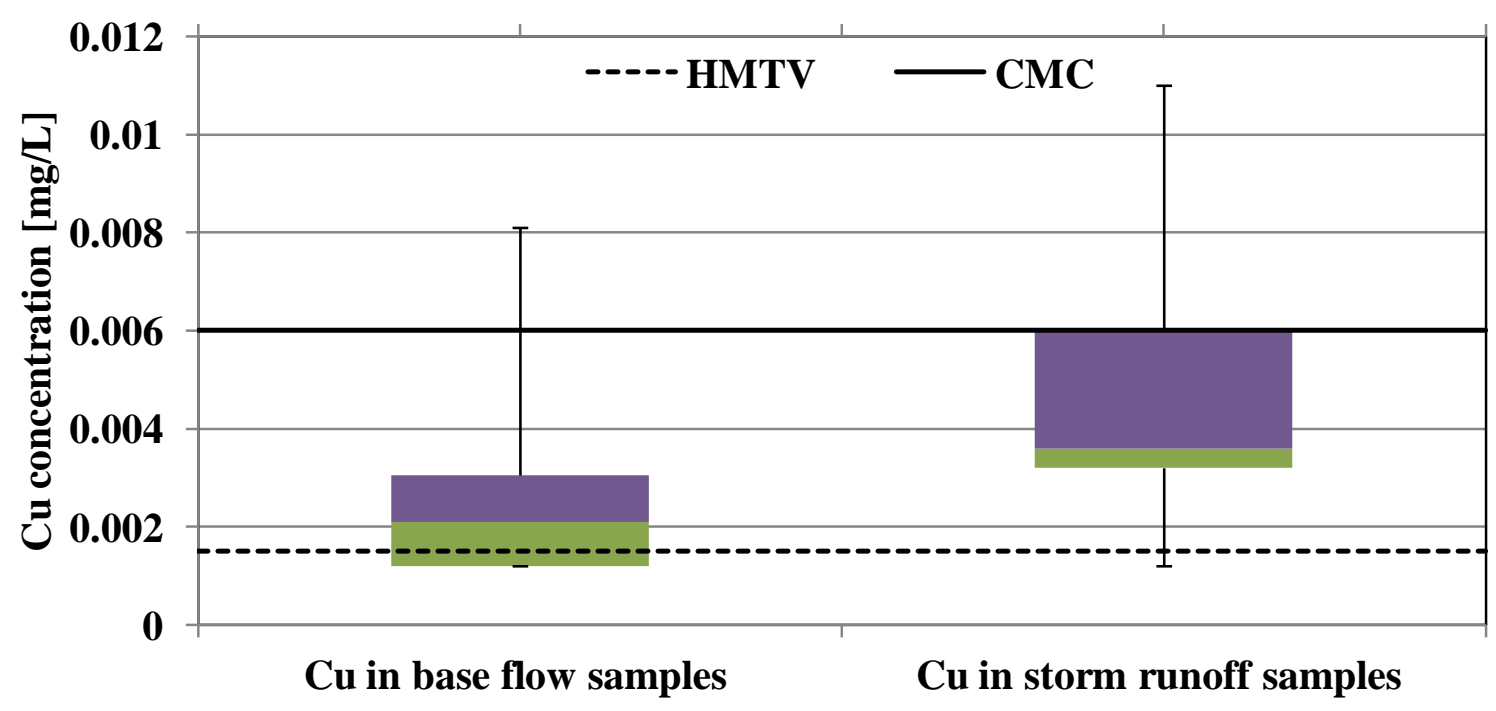

Figure 4.29 HMTV, CMC and statistical parameters of dissolved $\mathrm{Cu}$ concentrations $[\mathrm{mg} / \mathrm{L}]$ in base flow and storm runoff samples for site 10 of Karori Stream. 


\subsubsection{Dissolved Zn}

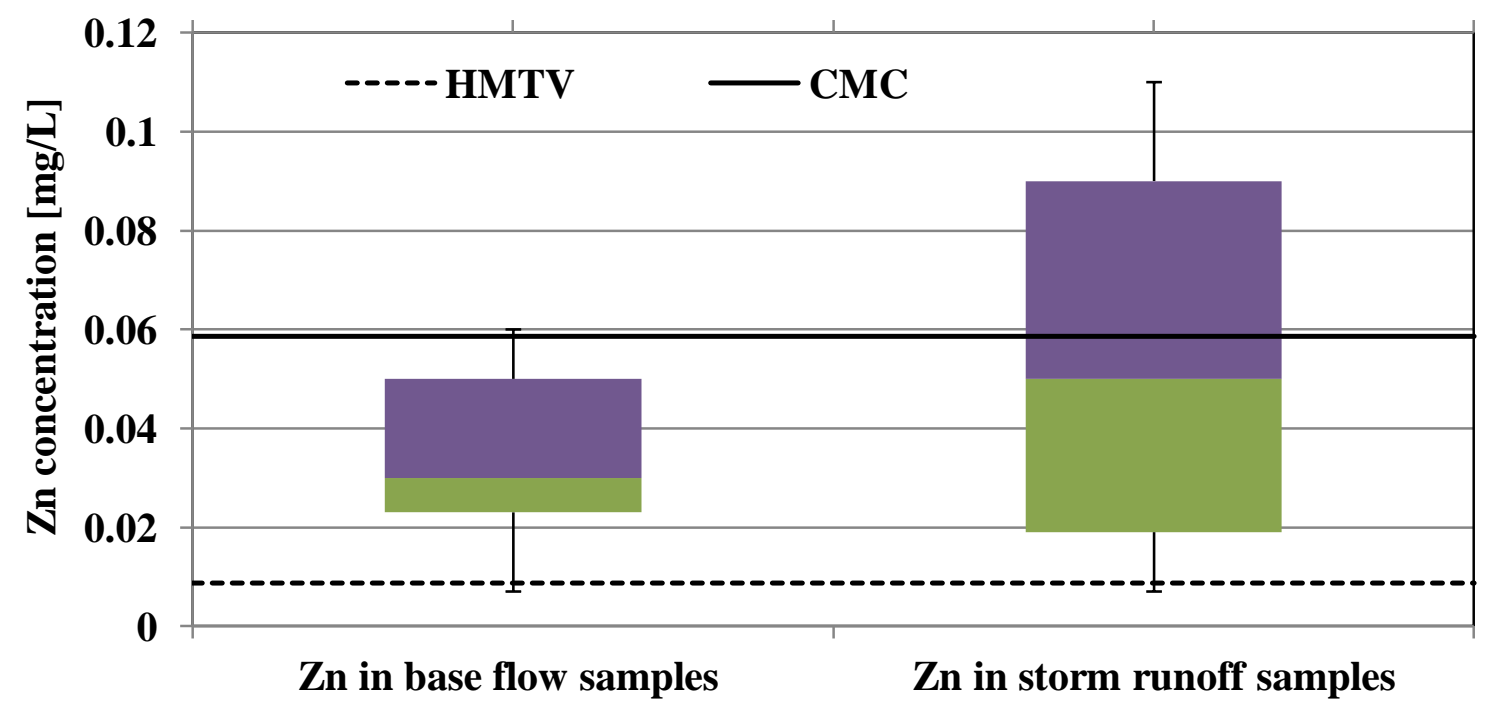

Figure 4.30 HMTV, CMC and statistical parameters of dissolved Zn concentrations $[\mathrm{mg} / \mathrm{L}]$ in base flow and storm runoff samples for site 10 of Karori Stream.

\subsubsection{Dissolved Fe}

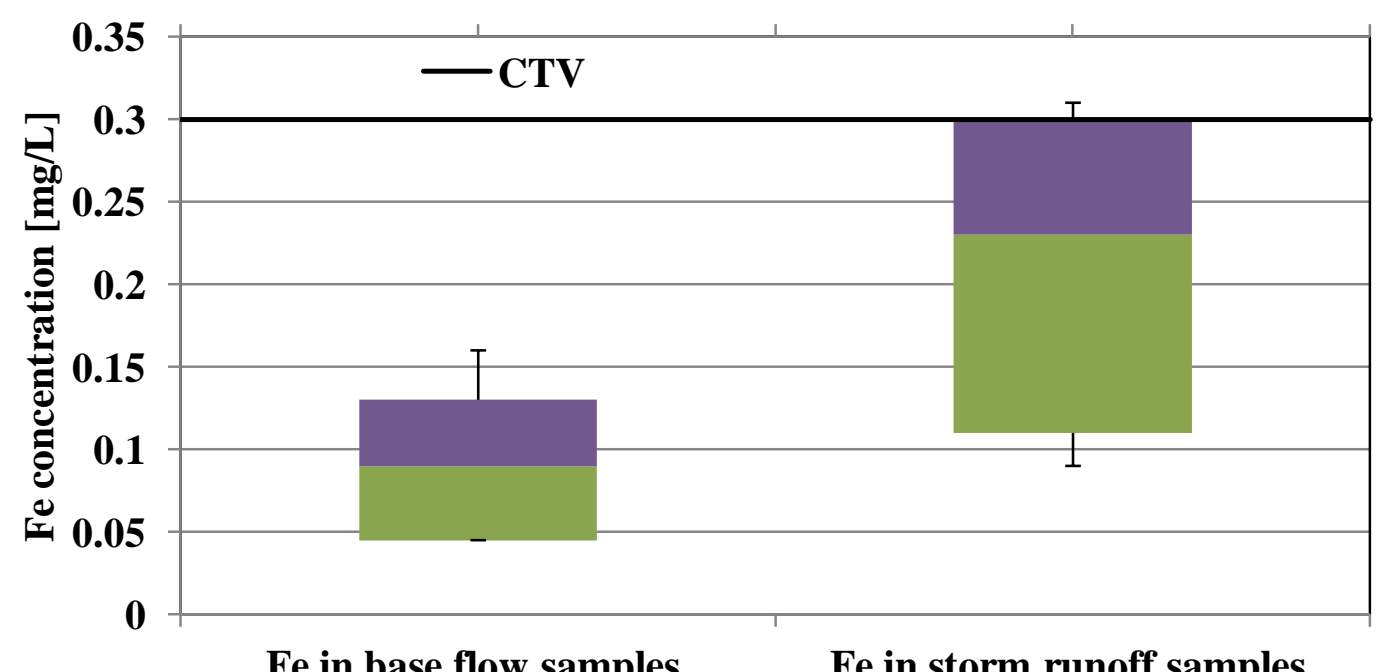

Figure 4.31 CTV and statistical parameter of dissolved Fe concentrations [mg/L] in base flow and storm runoff samples for site 10 of Karori Stream. 


\subsubsection{Site 11 Data}

A total of 17 base flow and 5 storm runoff samples were obtained at this site.

\subsubsection{Dissolved $\mathrm{Cu}$}

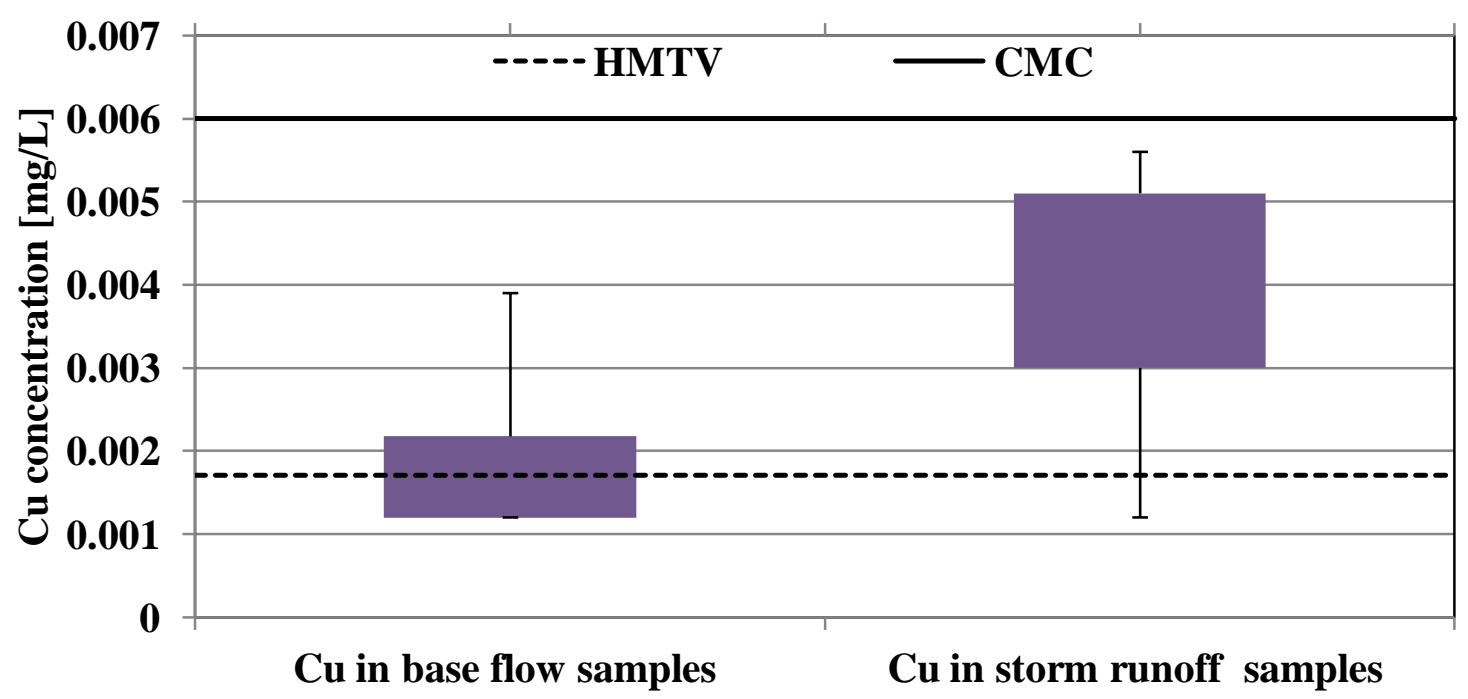

Figure 4.32 HMTV, CMC and statistical parameters of dissolved $\mathrm{Cu}$ concentrations $[\mathrm{mg} / \mathrm{L}]$ in base flow and storm runoff samples for site 11 of Makara Stream. 


\subsubsection{Dissolved Zn}

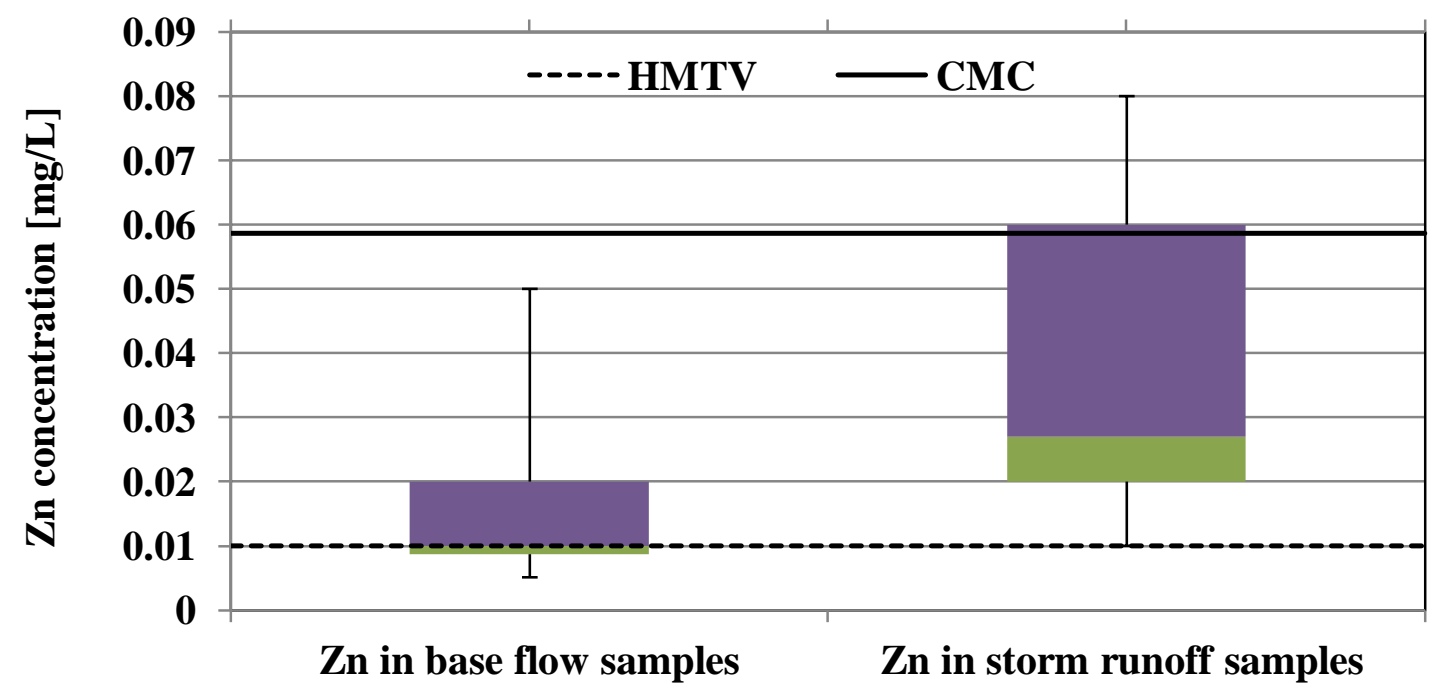

Figure 4.33 HMTV, CMC and statistical parameters of dissolved Zn concentrations $[\mathrm{mg} / \mathrm{L}]$ in base flow and storm runoff samples for site 11 of Makara Stream.

\subsubsection{Dissolved Fe}

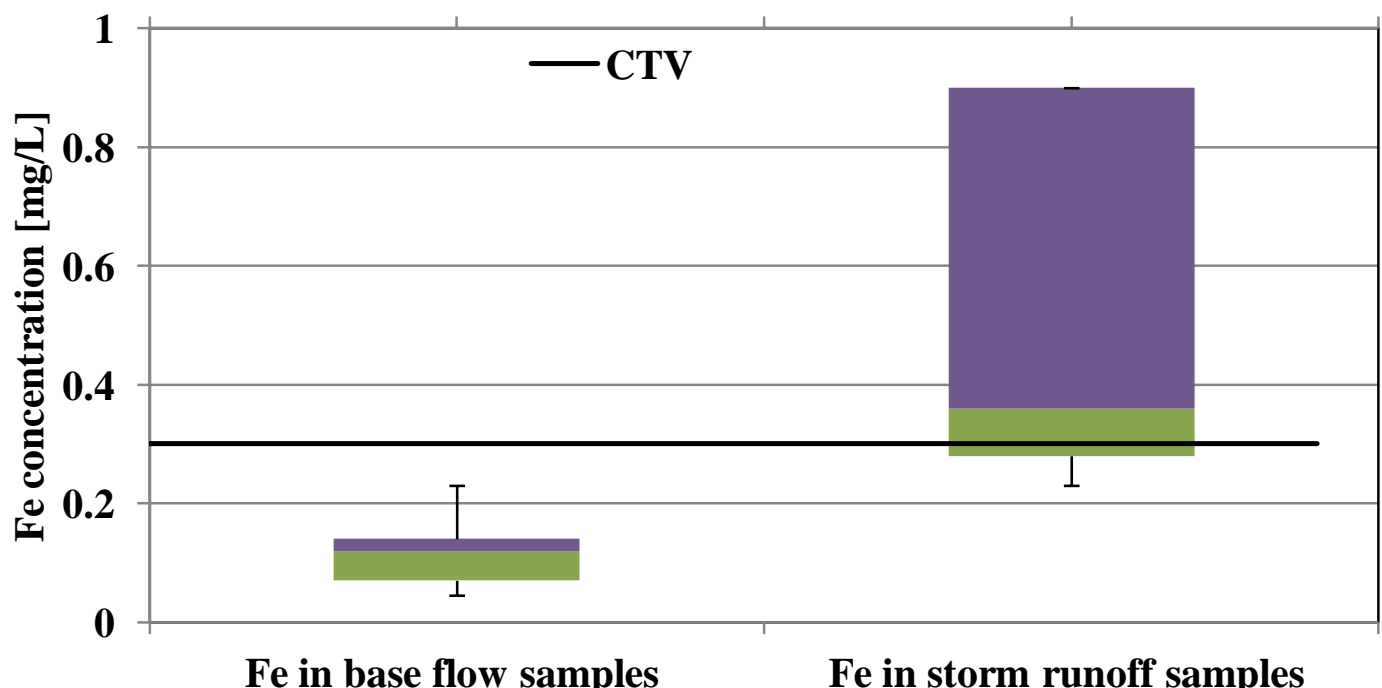

Figure 4.34 CTV and statistical parameters of dissolved Fe concentrations [mg/L] in base flow and storm runoff samples for site 11of Makara Stream. 


\subsubsection{Site 12 Data}

A total of 17 base flow and 5 storm runoff samples were obtained at this site.

\subsubsection{Dissolved Cu}

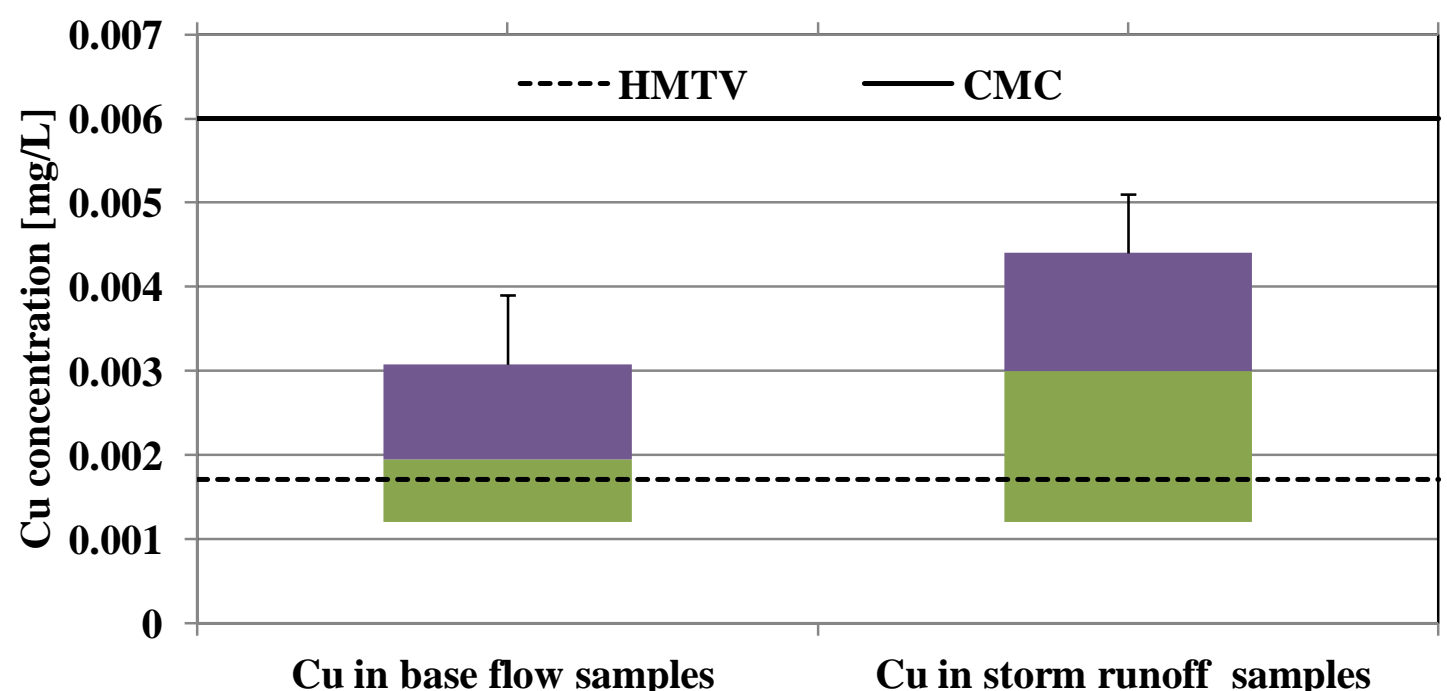

Figure 4.35 HMTV, CMC and statistical parameters of dissolved $\mathrm{Cu}$ concentrations $[\mathrm{mg} / \mathrm{L}]$ in base flow and storm runoff samples for site 12 of Makara Stream. 


\subsubsection{Dissolved Zn}

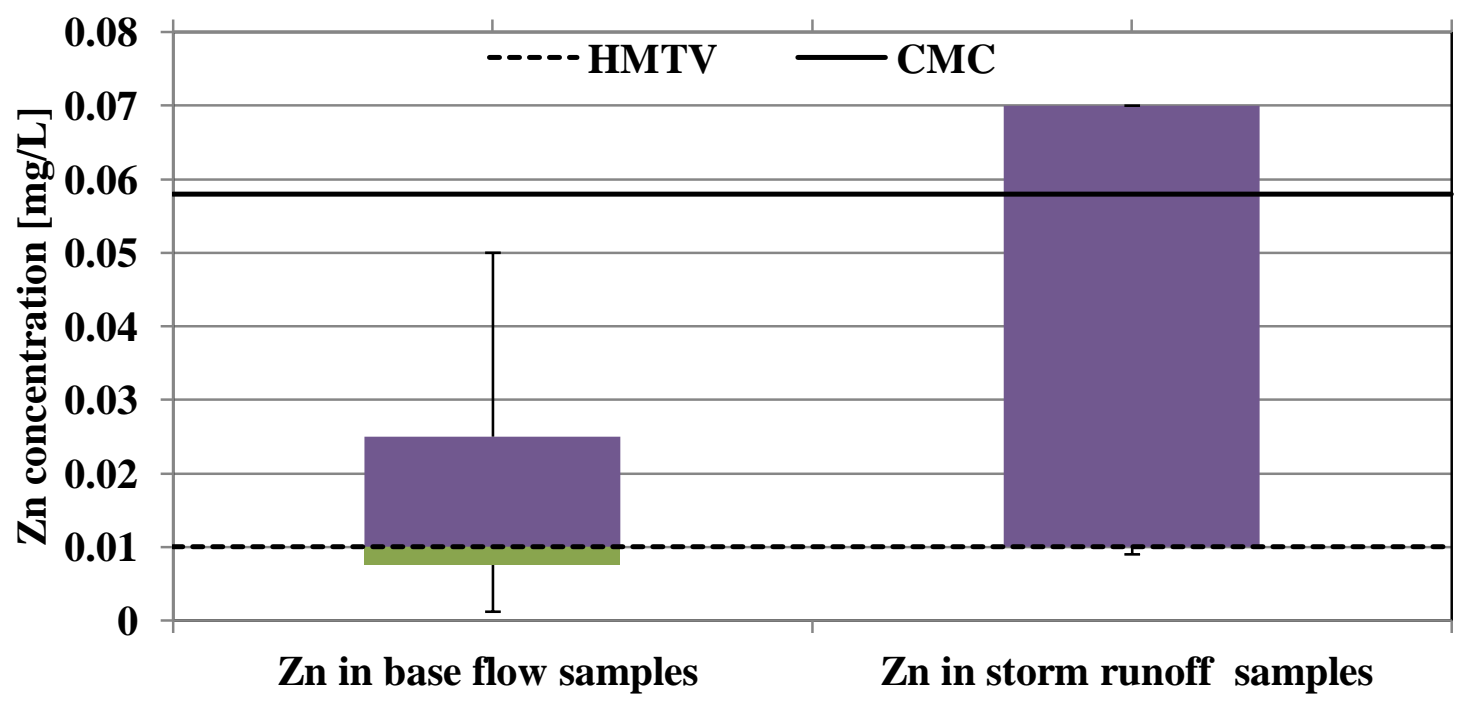

Figure 4.36 HMTV, CMC and statistical parameters of dissolved Zn concentrations $[\mathrm{mg} / \mathrm{L}]$ in base flow and storm runoff samples for site 12 of Makara Stream.

\subsubsection{Dissolved Fe}

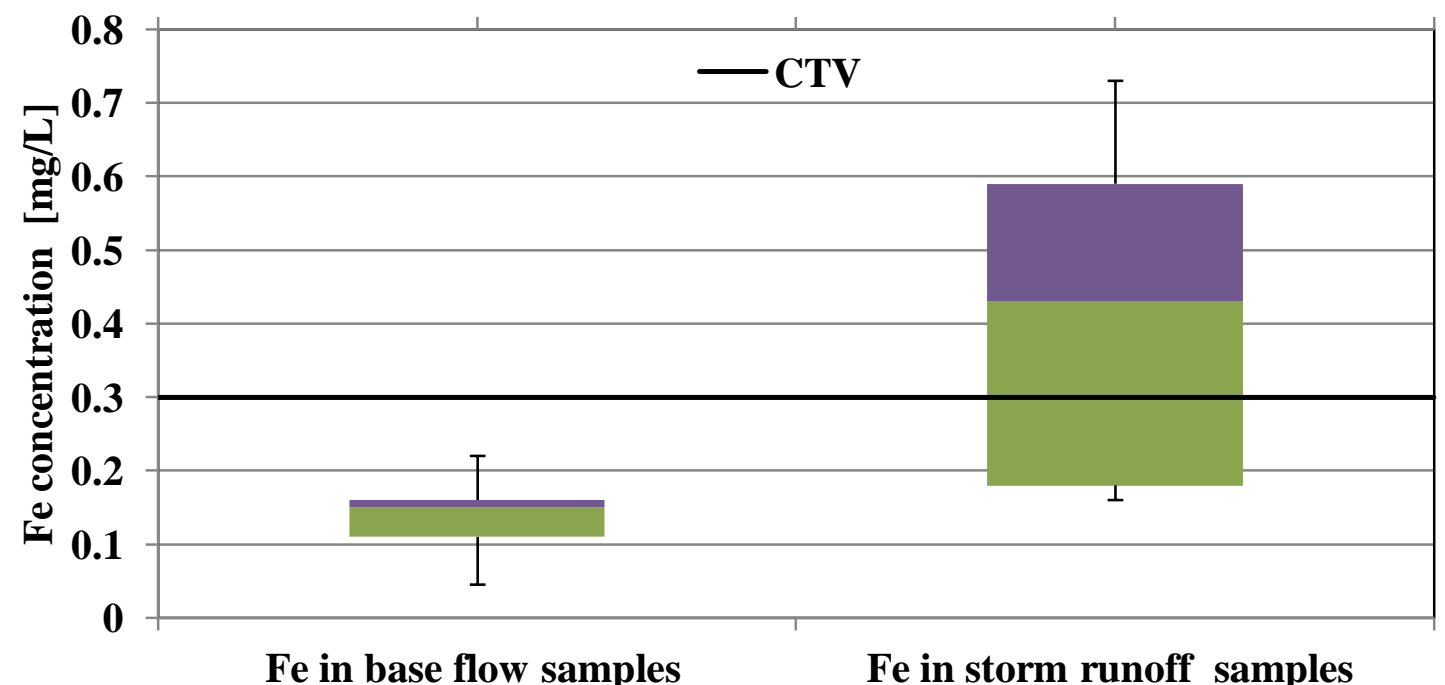

Figure 4.37 CTV and statistical parameters of dissolved Fe concentrations [mg/L] in base flow and storm runoff samples for site 12 of Makara. 


\subsubsection{Site 13 Data}

A total of 17 base flow and 5 storm runoff samples were obtained at this site. There is no water hardness information available for Ohariu Stream. According to data provided in a study conducted by the GWRC [7], the Ohariu water hardness value is comparable to Makara's value and hence the samples from site 13 of Ohariu Stream were evaluate using the HMTV of Makara Stream.

\subsubsection{Dissolved Cu}

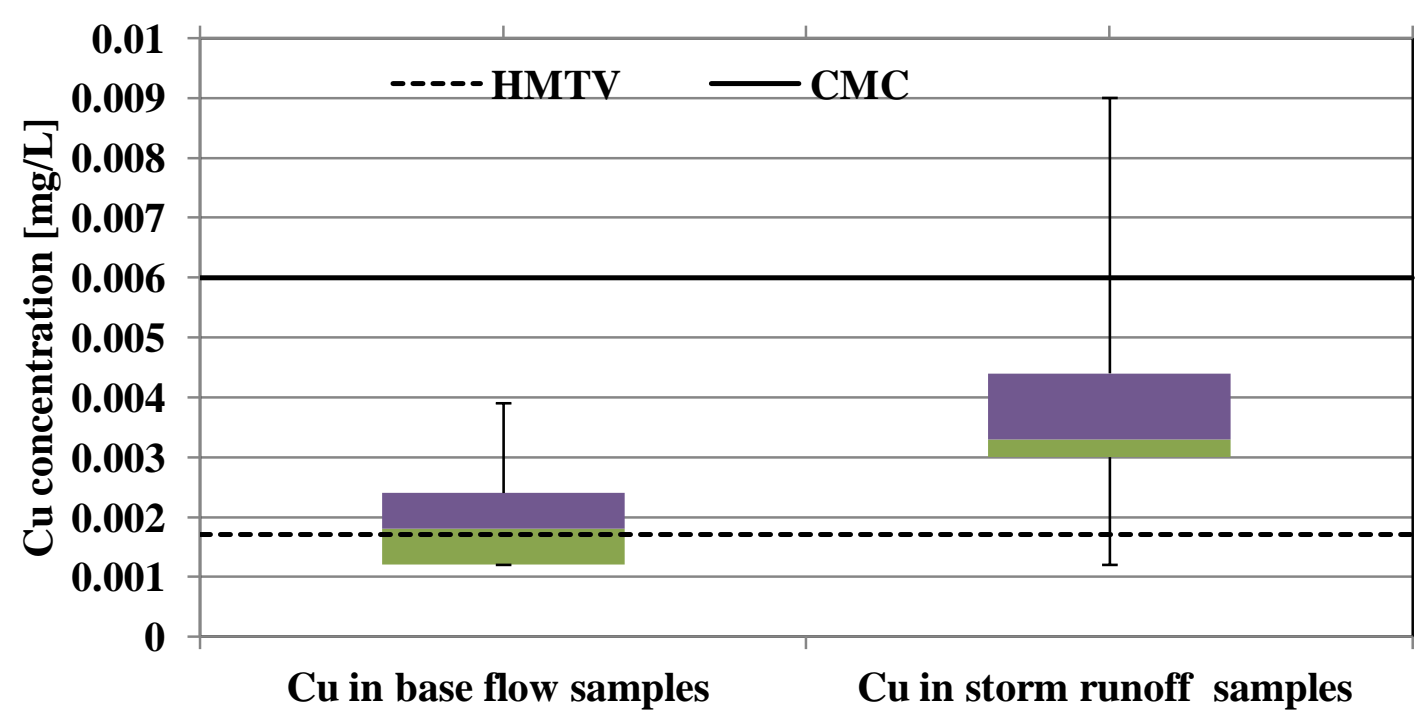

Figure 4.38 HMTV, CMC and statistical parameters of dissolved $\mathrm{Cu}$ concentrations $[\mathrm{mg} / \mathrm{L}]$ in base flow and storm runoff samples for site 13 of Ohariu Stream. 


\subsubsection{Dissolved Zn}

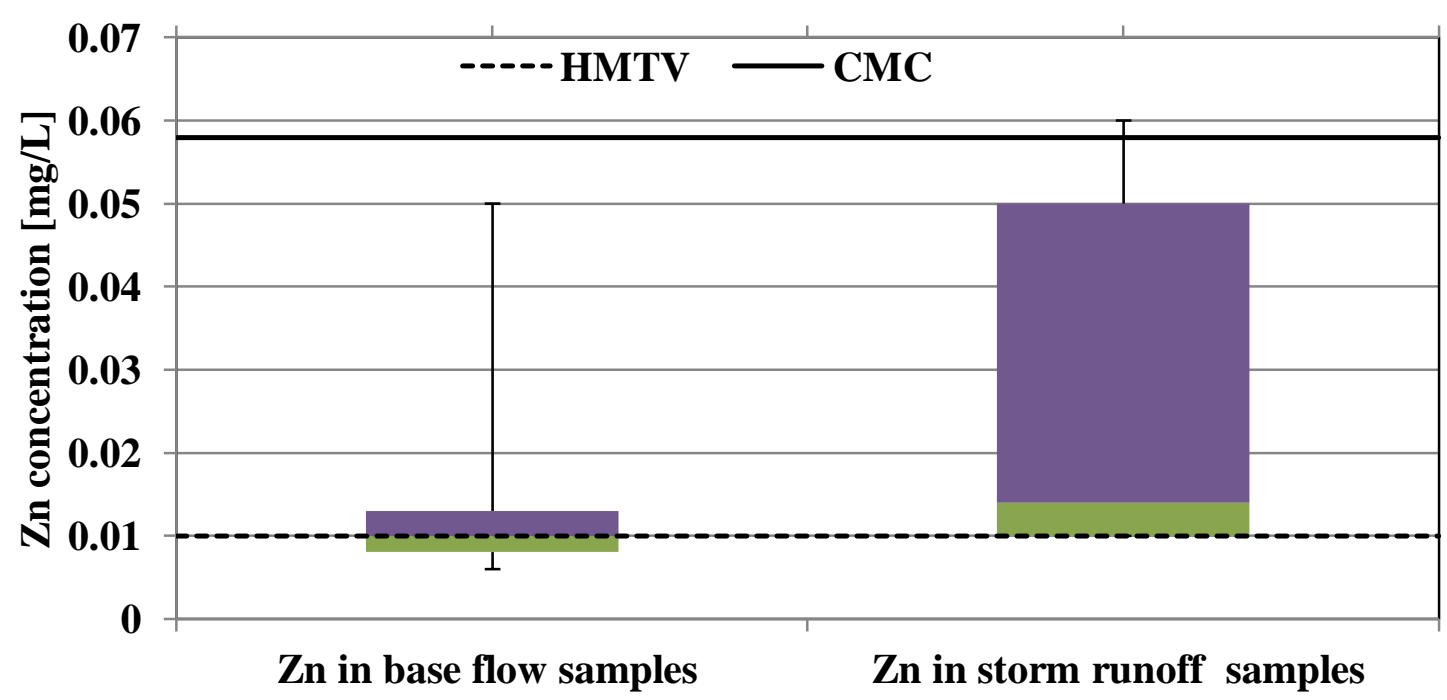

Figure 4.39 HMTV, CMC and statistical parameters of dissolved Zn concentrations $[\mathrm{mg} / \mathrm{L}]$ in base flow and storm runoff samples for site 13 of Ohariu Stream.

\subsubsection{Dissolved Fe}

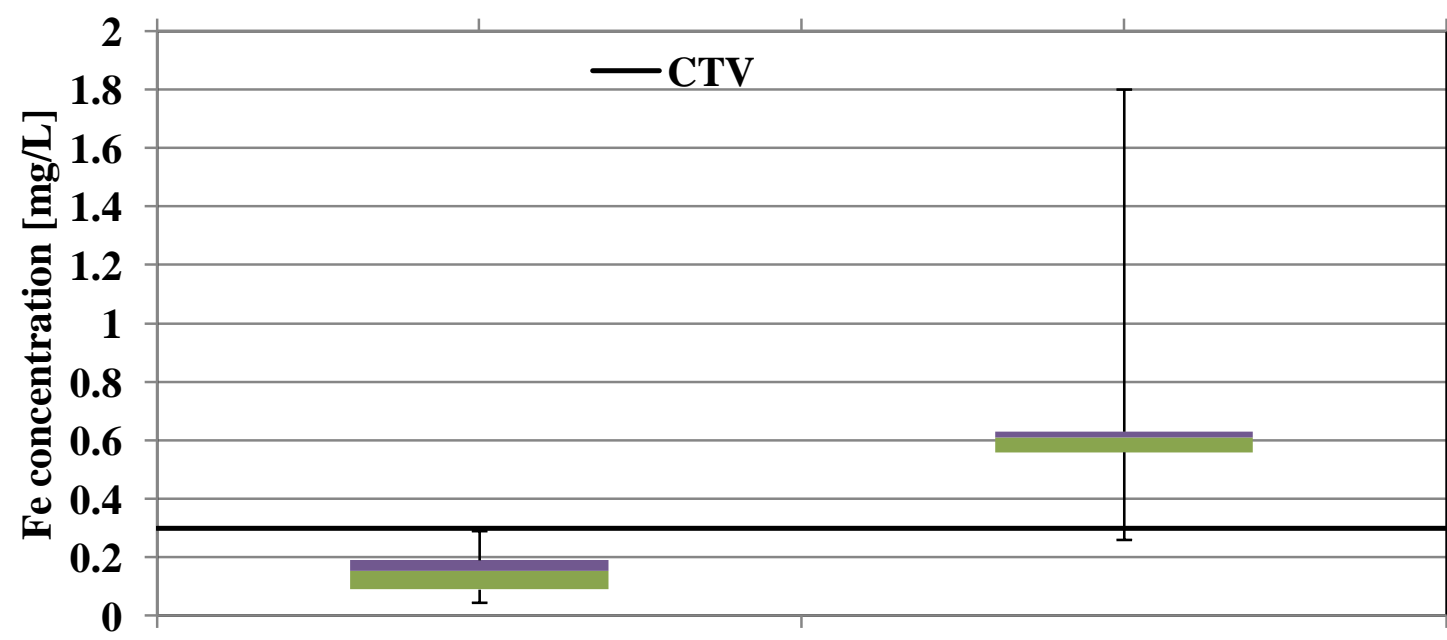

Fe in base flow samples

Fe in storm runoff samples

Figure 4.40 CTV and statistical parameters of dissolved Fe concentrations $[\mathrm{mg} / \mathrm{L}]$ in base flow and storm runoff samples for site 13 of Ohariu Stream. 


\subsection{Discussion of Base Flow and Wet Weather Flow Monitoring Data.}

\subsubsection{Dissolved $\mathrm{Cu}$}

\subsubsection{Base Flow Samples}

The median of dissolved $\mathrm{Cu}$ concentrations for base flow samples, as shown in Figure 4.41, exceeded the relative sustained toxicity triggers in all sites on the Porirua Stream (except site 3), site 5 on the Kenepuru Stream, all Karori Stream sites, site 12 on the Makara Stream and site 13 on the Ohariu Stream. The medians for samples from sites 6 and 7 on the Takapu Stream, site 3 on the Porirua Stream and site 11 on the Makara Stream did not exceed the corresponding chronic toxicity values.

Generally, as shown in Figure 4.42, the highest average of the median values of dissolved $\mathrm{Cu}$ concentrations in base flow samples were observed at suburban residential sites followed by light residential and then commercial sites. Notably, the average of the median values for dissolved $\mathrm{Cu}$ at rural sites did not exceed the ANZECC (2000) TV. This is an indication of the effect of residential discharges on the level of dissolved $\mathrm{Cu}$. Evidently, as shown in Figure 4.41, the highest median of dissolved $\mathrm{Cu}$ amongst Porirua Stream sites was found at site 1 which has the lowest water flow and is close to a concentrated residential area, Johnsonville. 


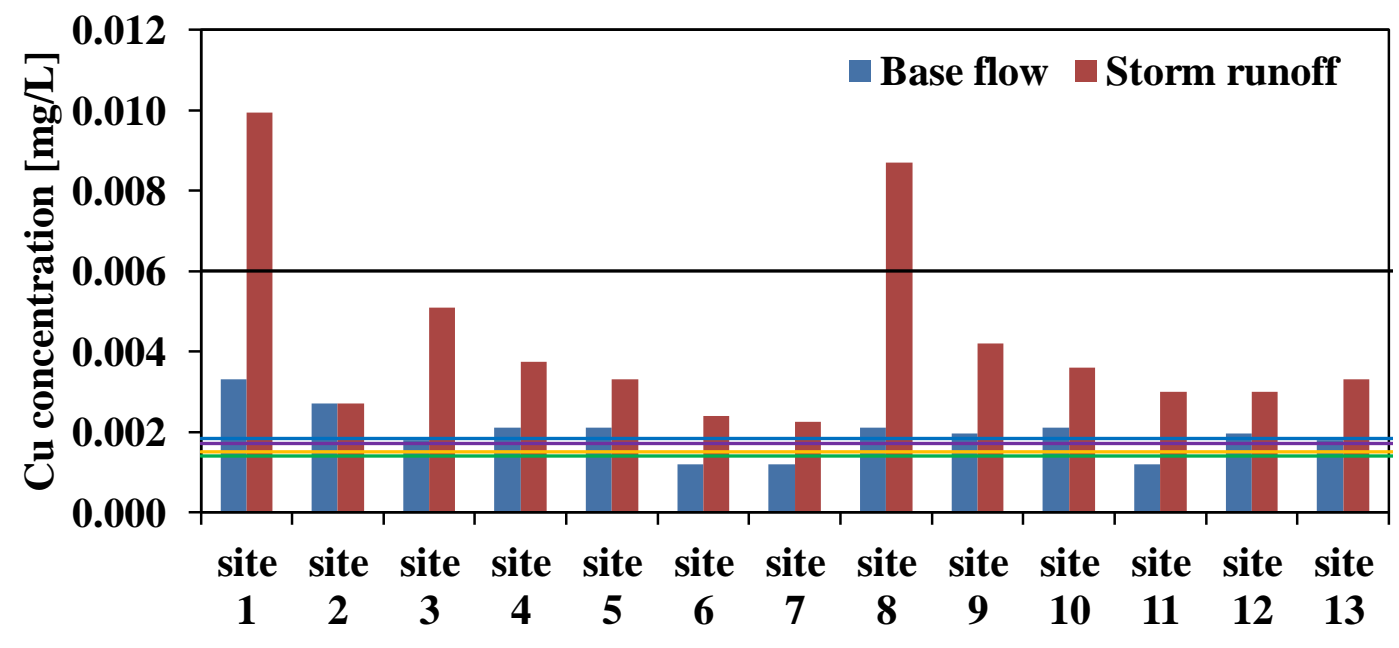

Figure 4.41 Median values for dissolved $\mathrm{Cu}$ concentrations, in base flow and storm runoff samples, for sites 1-13. Visual comparisons between the median values and the ANZECC (2000) TV (green line); HMTVs for Karori Stream (yellow line), Makara and Ohariu Streams (purple line) and Porirua Stream (blue line); and the CMC (black line).

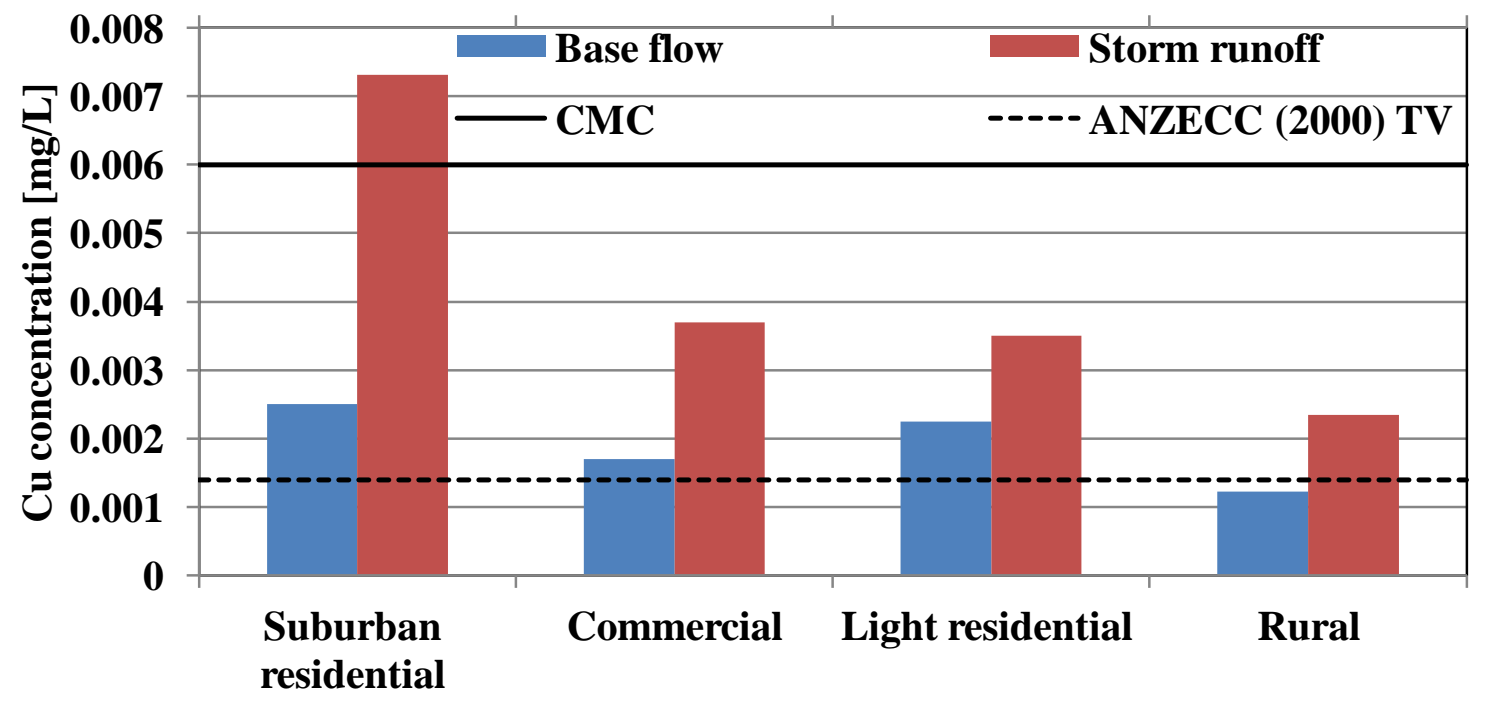

Figure 4.42 ANZECC (2000) TV, CMC and average of the median values for dissolved $\mathrm{Cu}$ concentrations in base flow and storm runoff samples for suburban residential (sites 1, 5 and 8), commercial (sites 3, 4, and 7), light residential (sites 2, 9 and 10) and rural sites (6, 11, 12 and 13). 
Previous monitoring data obtained between January 2008 and June 2009 of dissolved $\mathrm{Cu}$ for site 10 of Karori Stream by the GWRC [34], shown in Figure A1.8 in Appendix 1, reported that the median dissolved $\mathrm{Cu}$ concentrations was 0.0013 $\mathrm{mg} / \mathrm{L}$. Another study conducted by the GWRC, presented the results of a monitoring program from July 2009 to June 2010 for the same site where the median $\mathrm{Cu}$ concentrations was $0.00145 \mathrm{mg} / \mathrm{L}$ [4]. In our study the median of dissolved $\mathrm{Cu}$ concentrations at this site is $0.0021 \mathrm{mg} / \mathrm{L}$. The values from all three studies exceed the HMTV for this site. In addition, the current study showed that base flow median value for dissolved $\mathrm{Cu}$ concentrations at sites 1 and 4 were 0.0033 and $0.0021 \mathrm{mg} / \mathrm{L}$ respectively, and were higher than the concentrations measured on 09/05/2006 (0.002 and $0.0015 \mathrm{mg} / \mathrm{L}$ respectively) by the GWRC [8], (the GWRC measured a single base flow sample for each of these sites in their study). The three studies clearly demonstrate that the concentrations of dissolved $\mathrm{Cu}$ in Wellington urban streams have been increasing over the five years of monitoring ${ }^{9}$.

\subsubsection{Storm Runoff Samples}

The medians of dissolved $\mathrm{Cu}$ concentrations are higher in storm runoff samples than the corresponding base flow samples, except at site 2 where they are the same, as shown in Figure 4.41. The medians of dissolved $\mathrm{Cu}$ in all storm runoff samples at all sites exceeded the respective sustained exposure toxicity triggers. Notably, the medians of dissolved $\mathrm{Cu}$ concentration at sites 1 of Porirua Stream and 8 of Karori Stream are the only figures that exceeded the $\mathrm{CMC}$, and the median of dissolved $\mathrm{Cu}$ concentrations at sites 3 almost approached the CMC.

Generally, as illustrated in Figure 4.42, the highest average of the median values for dissolved $\mathrm{Cu}$ concentrations was observed at sites located in suburban residential areas, and was the only figure that exceeded the CMC. The concentrations at the other types of sites were lower by a factor of at least two, as shown in Figure 4.42.

\footnotetext{
${ }^{9}$ Different sampling and testing methods used in the three studies could be a factor of the increment found in dissolved $\mathrm{Cu}$ concentration.
} 
Storm runoff contained elevated dissolved $\mathrm{Cu}$ concentrations that are higher than base flow and the recommended chronic toxicity triggers. The concentrations exceed the acute toxicity triggers in suburban residential catchments.

The observed elevated concentrations could originated from various sources. A study by Kennedy in the Wellington region in 1980, reported elevated concentrations of $\mathrm{Cu}$ in accumulated particulate materials of urban gutter and road surfaces [16]. These results showed that $\mathrm{Cu}$ contaminated all dust and accumulated particulates samples in the Wellington region. The author suggested the corrosion of trolley bus wires (this could only be applicable for Karori Stream sites) and vehicle brake lining wear could account for some of the elevation in the gutter/road dusts of the Wellington region [16]. More detailed results were provided in another study done by Kennedy and Gadd [15]. They examined several potential sources of $\mathrm{Cu}$ in the New Zealand's environment. The results indicated that the highest median of $\mathrm{Cu}$ concentration was for brake pad dust samples $(219.5 \mathrm{mg} / \mathrm{kg})$; and the median for brake pads, tyres, raw bitumen and road bitumen were $35.5,1,<1$, and $46.3 \mathrm{mg} / \mathrm{kg}$ respectively.

Our analysis of rainwater runoff samples from roofs and paved surfaces, discussed in Chapter 5, showed that elevated concentrations of dissolved $\mathrm{Cu}$ were found, especially in first flush samples, which agrees with the previously mentioned studies. However this study has identified an additional source of $\mathrm{Cu}$, the analysis of urban atmospheric rainfall samples showed the presence of dissolved $\mathrm{Cu}$ at concentrations higher than the ANZECC (2000) TV, and the highest concentrations were observed in samples collected from the Mt. Victoria tunnel. This source has not been considered in previous works in the country. The data on atmospheric rainfall samples are also discussed in Chapter 5.

As noted in Chapter 2, there are only a limited number of storm water studies from New Zealand, particularly investigating heavy metals. The results of the GWRC study [7], concluded that the concentrations of dissolved $\mathrm{Cu}$ in Wellington storm water were higher than the ANZECC (2000) TV, which is consistent with this study, Figure 4.41 and Figure 4.43. Moreover, the average of the median values for dissolved $\mathrm{Cu}$ concentrations $(0.0073 \mathrm{mg} / \mathrm{L})$ at suburban residential catchments is higher than what was observed earlier $(0.00545 \mathrm{mg} / \mathrm{L})$ [7]. The same study showed markedly higher median for dissolved $\mathrm{Cu}$ in samples collected from commercial 
catchments, shown in Figure 4.44, than those observed in this study. This study recorded concentrations for a suburban residential catchment (site 1) similar to those recorded for commercial catchments.

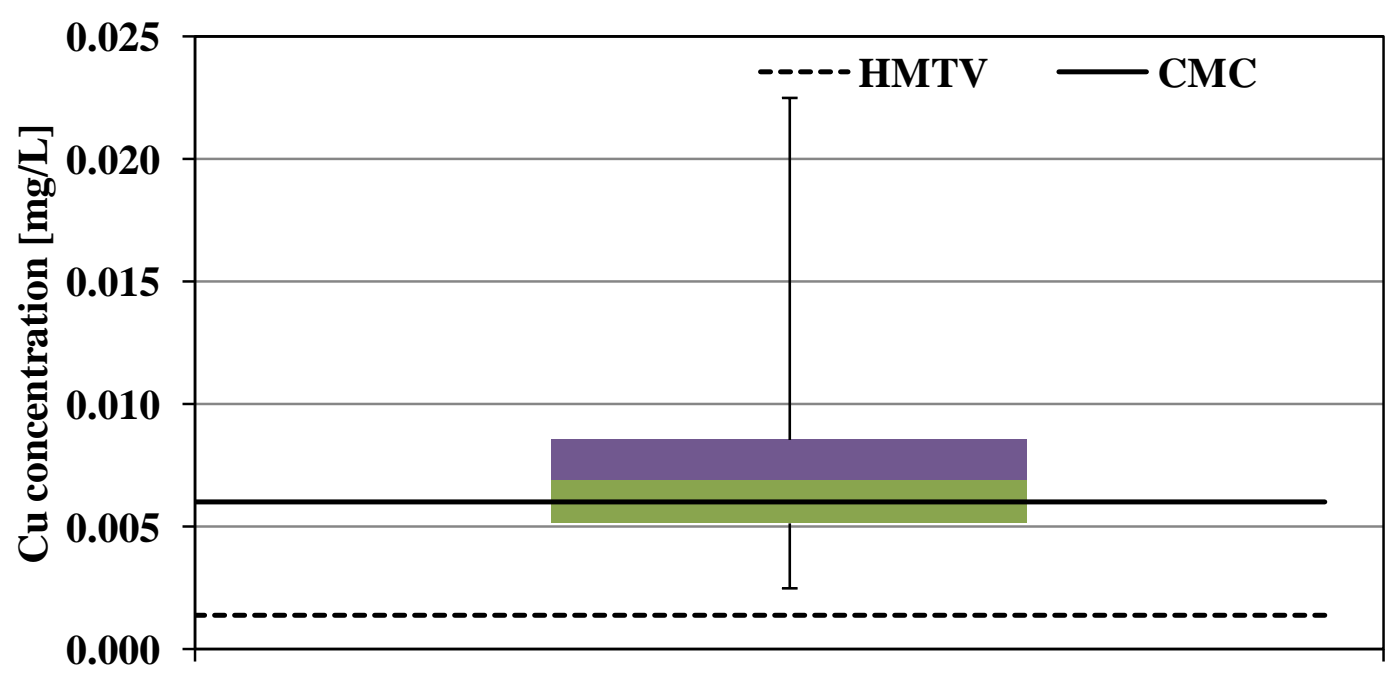

$\mathrm{Cu}$ in storm runoff samples by the GWRC

Figure 4.43 ANZECC (2000) TV and a summary of dissolved $\mathrm{Cu}$, range 0.0025$0.0225[\mathrm{mg} / \mathrm{L}]$, in 11 monitored storm runoff at 11 different sites within the Wellington region by the GWRC [7]. Note that this figure is constructed from data presented in a table in [7].

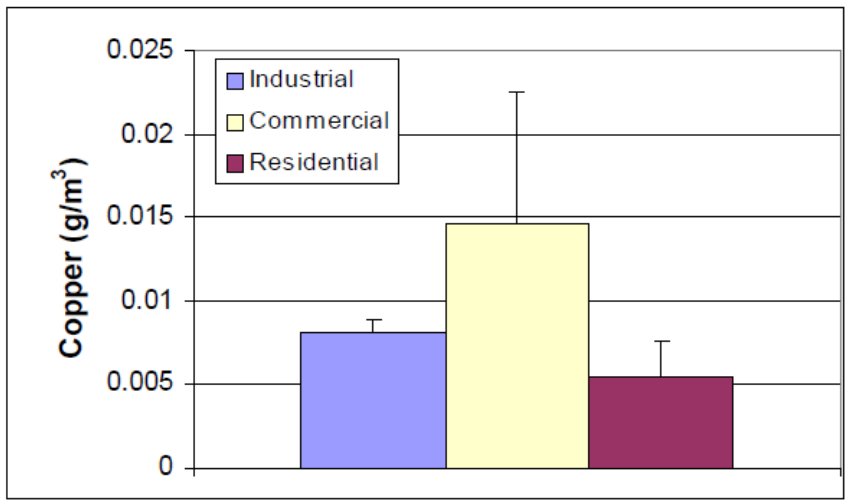

Figure 4.44 The median dissolved $\mathrm{Cu}$ concentrations $\left[\mathrm{g} / \mathrm{m}^{3}\right]$, standard error and land-use in monitored storm runoff at 6 residential sites: Owhiro Stream; Browns Stream; The Parade; McLeod Park; Duck Creek; Grassleas Reserve and five industrial and commercial sites: Te Roto Drive; Semple Street ; Hutt Park Road; Waring Taylor Street; Parkside Road. Figure taken from [7]. 
Comparison with the Rotorua data set [6], discussed in Chapter 2, shows that the data are comparable (Table 4.1).

Table 4.1 Comparison between the average of the median values for dissolved $\mathrm{Cu}$ concentrations for residential and commercial catchments obtained by this study and median values of the respective catchments in the study conducted in Rotorua.

\begin{tabular}{|c|c|c|c|c|}
\hline Year & Place & Catchment type & $\begin{array}{c}\text { Cu concentration } \\
{[\mathrm{mg} / \mathrm{L}]}\end{array}$ & Reference \\
\hline 2011 & Wellington & $\begin{array}{c}\text { Suburban } \\
\text { residential }\end{array}$ & 0.0073 & This study \\
\hline 2011 & Wellington & Light residential & 0.0032 & This study \\
\hline 1999-2001 & Rotorua City & Residential & 0.0041 & [6] \\
\hline 2011 & Wellington & Commercial & 0.0037 & This study \\
\hline 1999-2001 & Rotorua City & Commercial & 0.005 & [6] \\
\hline
\end{tabular}

\subsubsection{First Flush and Composite Samples}

As can be seen in Figure 4.45, dissolved $\mathrm{Cu}$ concentrations in all first flush samples exceeded the respective chronic toxicity triggers except at site 9. Except at sites 4 and 9, composite figures exceeded the relevant sustained toxicity triggers. No exceedance was recorded for the CMC criteria. Six of a total of eight monitored storms runoff showed the first flush effect. 


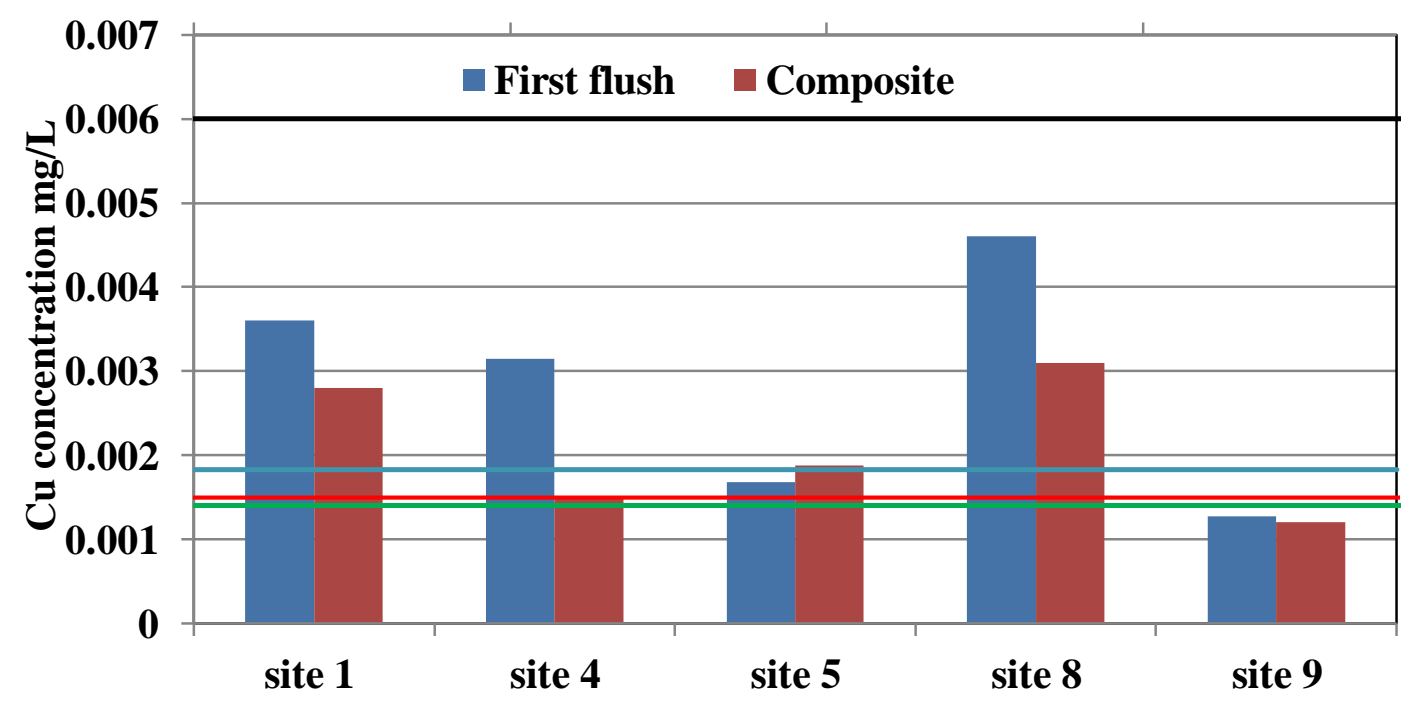

Figure 4.45 The median values for sites 1 and 8 and single data for sites 4, 5, and 9 of dissolved $\mathrm{Cu}$ concentrations in first flush and composite samples. Also shown are visual comparisons of $\mathrm{Cu}$ concentrations in first flush and composite samples against the ANZECC (2000) TV (green line); HMTVs for Karori Stream (red line), and Porirua Stream (blue line); and the CMC (black line).

Compared to previous work, the concentrations of dissolved $\mathrm{Cu}$ in first flush and composite samples were lower than those observed by the GWRC between 2005 and 2007 [8], as shown in Figure 4.46. Moreover, the same study showed that first flush concentrations of dissolved $\mathrm{Cu}$ in 17 storm runoff events were lower than composite samples and two first flush and eight composite samples exceeded the CMC. In contrast, this study demonstrates that dissolved $\mathrm{Cu}$ in first flush samples tended to be higher than the composite samples and no sample exceeded the CMC, Figure 4.46. 


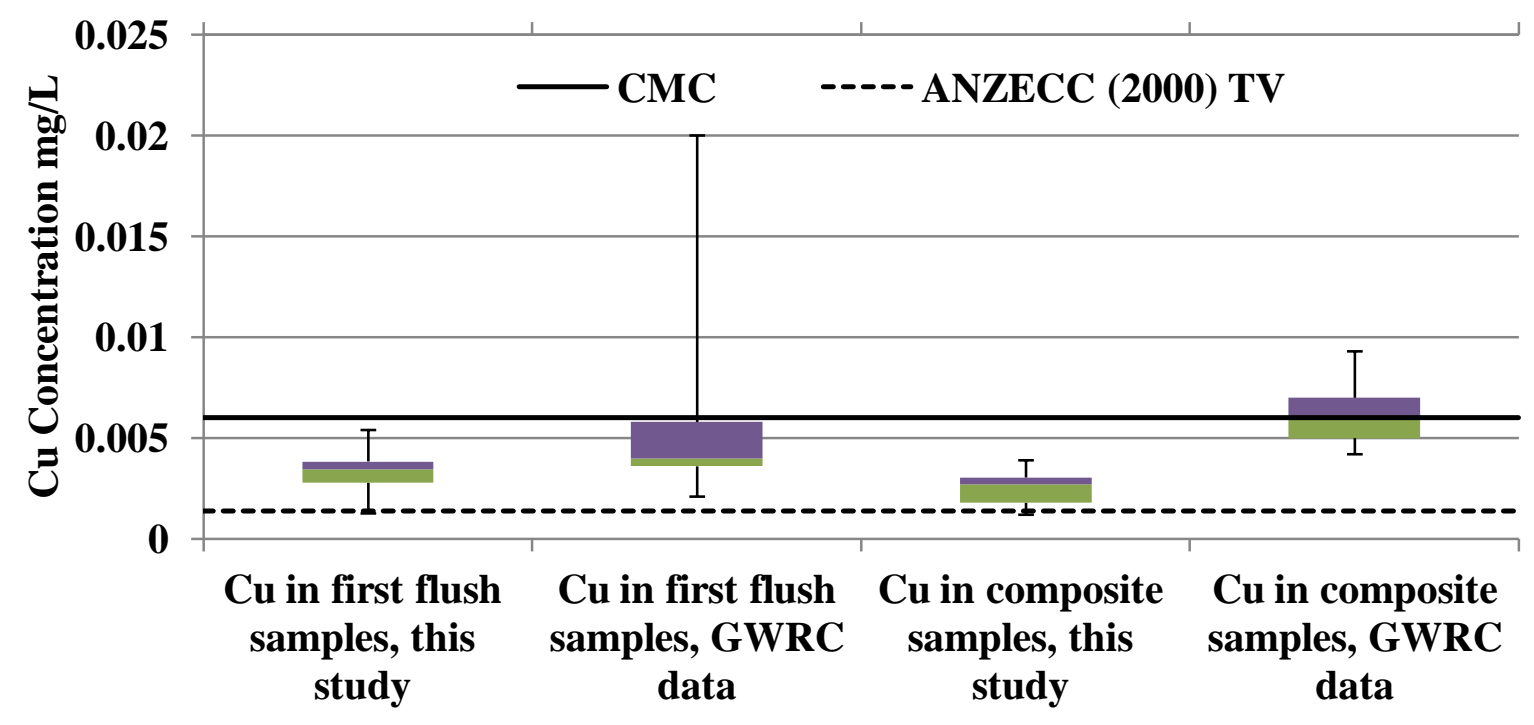

Figure 4.46 ANZECC (2000) TV, CMC and summary of dissolved $\mathrm{Cu}$ concentrations $[\mathrm{mg} / \mathrm{L}]$ in first flush, and composite samples by this study and by the GWRC [8]. 


\subsubsection{Summary of Dissolved Cu Concentration in Base Flow and Wet Weather Flow Waters.}

The median values for dissolved $\mathrm{Cu}$ concentrations in base flow exceeded the respective HMTVs and ANZECC (2000) TV at 9 of 13 sites. Severe excedence was recorded for sites 1 and 2 of Porirua Stream. The medians of dissolved $\mathrm{Cu}$ concentrations in base flow condition tended to be higher than those reported by the GWRC from previous monitoring.

The medians of dissolved $\mathrm{Cu}$ concentrations in storm runoff waters exceeded the CMC at sites 1 and 8, and this is attributed to the sites being adjacent to concentrated residential areas. The average of the median value for samples collected from suburban residential catchments is higher than those collected from other catchments. The average of the median values of dissolved $\mathrm{Cu}$ concentrations in storm runoff waters for residential areas was higher than those recorded by the GWRC [7]. The Rotorua study reported comparable concentrations to those reported in this study for storm water runoff from suburban and light residential and commercial catchments.

The first flush effect was exhibited in six storm runoff events and the concentrations of dissolved $\mathrm{Cu}$ in first flush and composite samples were higher than the relevant chronic toxicity triggers, except the storm runoff at site 9. All first flush and composite samples were lower than the CMC. Generally, the reported first flush monitoring data is lower what was observed during 2005-2007 by the GWRC [8]. 


\subsubsection{Dissolved Zn}

\subsubsection{Base Flow Samples}

As can be seen in Figure 4.47, the median of dissolved $\mathrm{Zn}$ concentration in base flow samples for all Porirua Stream sites; site 5 of Kenepuru Stream; sites 6 and 7 of Takapu Stream; and all Karori Stream sites exceeded the respective sustained toxicity triggers. The rural sites of Makara and Ohariu Streams however, did not exceed the HMTV but almost equal to it. As shown in Figure 4.48, suburban residential catchments had the highest value of dissolved $\mathrm{Zn}$ concentrations followed by commercial and then light residential. The average of the median values for dissolved $\mathrm{Zn}$ for the rural sites was the lowest and about equal to the ANZECC (2000) TV.

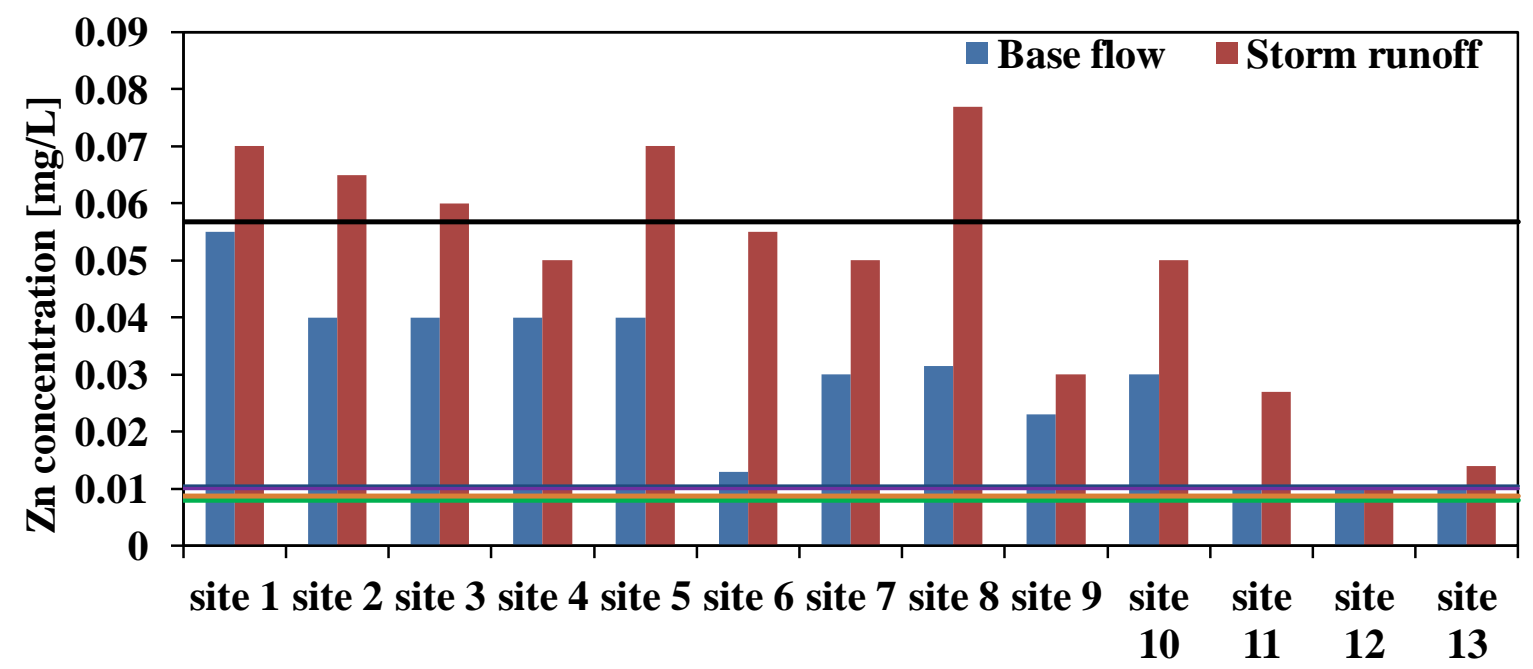

Figure 4.47 The median values of dissolved $\mathrm{Zn}$ concentrations in base flow and storm runoff samples obtained from sites 1-13. Visual comparisons of the median of dissolved Zn concentrations against the ANZECC (2000) TV (green line); HMTV for Karori Stream (yellow line), Makara and Ohariu Streams (purple line) and Porirua Stream (blue line); and (CMC) (black line). 


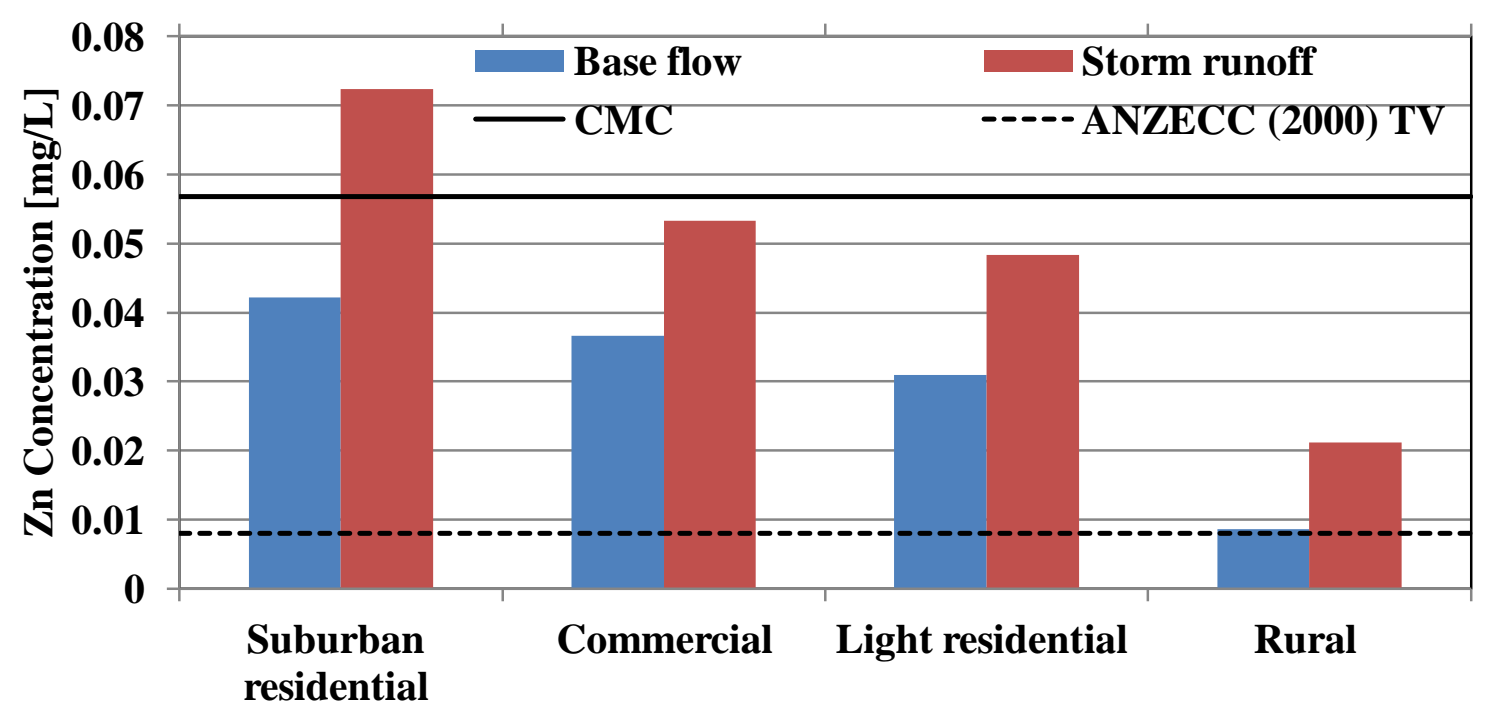

Figure 4.48 ANZECC (2000) TV, CMC and the average of the median values for dissolved $\mathrm{Zn}$ concentrations in base flow and storm runoff samples for suburban residential (sites1, 5 and 8); commercial (sites 3, 4, and 7); light residential (sites 2, 9 and 10) and rural sites (sites 6, 11, 12 and 13).

According to unpublished data of the GWRC for site 10, summarised in Figure A1.8 in Appendix 1, the median of dissolved $\mathrm{Zn}$ data obtained between January 2008 until June 2009 was $0.021 \mathrm{mg} / \mathrm{L}$ [34]. Perrie, et al. showed the results of the GWRC monitoring program during July 2009 to June 2010 where the median of the data was $0.018 \mathrm{mg} / \mathrm{L}$ [4]. The current study observed the median of $\mathrm{Zn}$ concentrations for the period of monitoring to be $0.03 \mathrm{mg} / \mathrm{L}$. All the three studies agree in that dissolved $\mathrm{Zn}$ concentrations exceeded the HMTV at site 10 of Karori Stream; and the highest value was associated with the current study. In regard to Porirua Stream, the median of dissolved $\mathrm{Zn}$ concentration appears to be higher for site 1 and lower for site 2 than the concentrations measured on 09/05/2006 by the GWRC, 0.017 and 0.043 $\mathrm{mg} / \mathrm{L}$ respectively [8], (the GWRC measured a single base flow sample for each of these sites in their study). 


\subsubsection{Storm Runoff Samples}

Overall, the medians for dissolved $\mathrm{Zn}$ concentrations were higher in storm runoff samples than the corresponding base flow samples, except for site 12. As can be seen in Figure 4.47, the medians of dissolved $\mathrm{Zn}$ in storm runoff samples at all sites, except site 12 , exceeded the respective sustained toxicity triggers. The CMC was exceeded by sites $1,2,3,5$ and 8 .

As with dissolved $\mathrm{Cu}$, the average of the median of dissolved $\mathrm{Zn}$ concentrations for samples collected from suburban residential catchments were the highest followed by samples from commercial and then light residential sites. Rural sites showed the lowest value, as shown in Figure 4.48. Clearly, dissolved Zn was more abundant in storm water than dissolved $\mathrm{Cu}$.

Kennedy, reported high $\mathrm{Zn}$ concentration in accumulated particulates on gutter and road surfaces in the Wellington region. The presence of $\mathrm{Zn}$ as a contaminant in accumulated particulate materials on gutter/road surface was attributed to soil derived Zn; zinc-based alloys (galvanised roofs), motor oils and vehicle emissions, tyres, bake pad/ brake pad dust and paint materials [16]. Kennedy and Gadd measured significantly higher median $\mathrm{Zn}$ concentrations in samples, ranging between 5.5 and $8310 \mathrm{mg} / \mathrm{kg}$, for tyres (highest), brake pad dust, brake pads, raw bitumen, and road bitumen (lowest) used in New Zealand [15]. 
Analysis of rainwater runoff from roofs and paved surface samples in the current study revealed elevated concentrations of dissolved $\mathrm{Zn}$ especially in first flush samples, whereas accumulated dust/particulates are flushed off by the first portion of rainfall. Runoff from galvanised roofs showed very high concentrations even after the first flush, indicating that $\mathrm{Zn}$ leaches from the surface of the roofs.

The analysis of urban atmospheric rainfall samples showed the presence of dissolved $\mathrm{Zn}$ at concentrations higher than ANZECC (2000) TV, and more elevated concentrations were observed at a site adjacent to a road with high traffic density (Mt. Victoria tunnel). Refer to atmospheric rainfall samples in Chapter 5.

Both this study and the data collected by the GWRC [7], illustrated in Figure 4.49, point to the same conclusion, that the concentrations of dissolved $\mathrm{Zn}$ in Wellington storm waters are higher than the ANZECC (2000) TV. They also agree that Zn concentrations exceeded the $\mathrm{CMC}$ in samples collected from residential catchments. However, they are at odds regarding dissolved $\mathrm{Zn}$ from commercial catchments, where the concentration exceeded the CMC in the GWRC data [7] (Figure 4.50). It is worth noting that dissolved $\mathrm{Zn}$ concentrations at site 1 were similar to those reported by the GWRC for industrial catchments. 


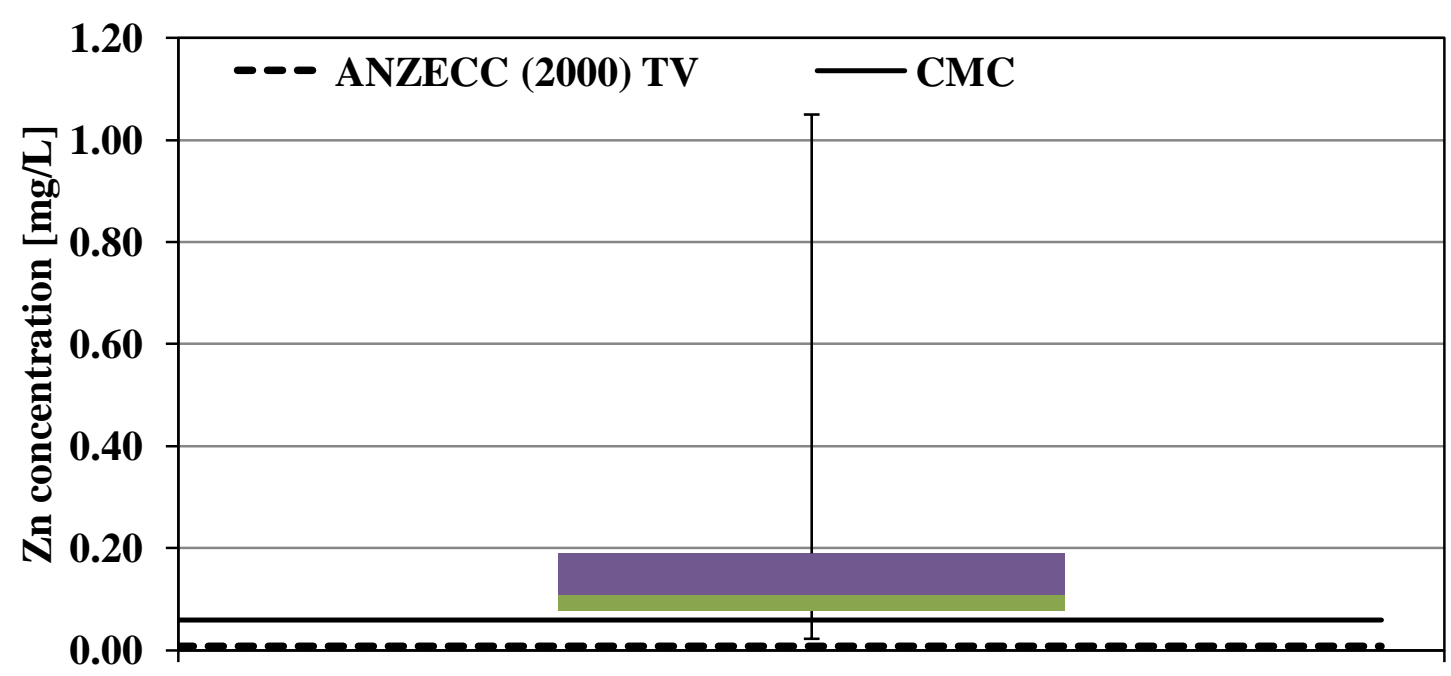

Zn in storm runoff samples by the GWRC

Figure 4.49 ANZECC (2000) TV and a summary of dissolved Zn, range 0.022-1.05 $\mathrm{mg} / \mathrm{L}$, in 11 storm runoff water samples at 11 different sites within the Wellington region by the GWRC, 2002 [7]. Note that this figure is constructed from data presented as a table in [7].

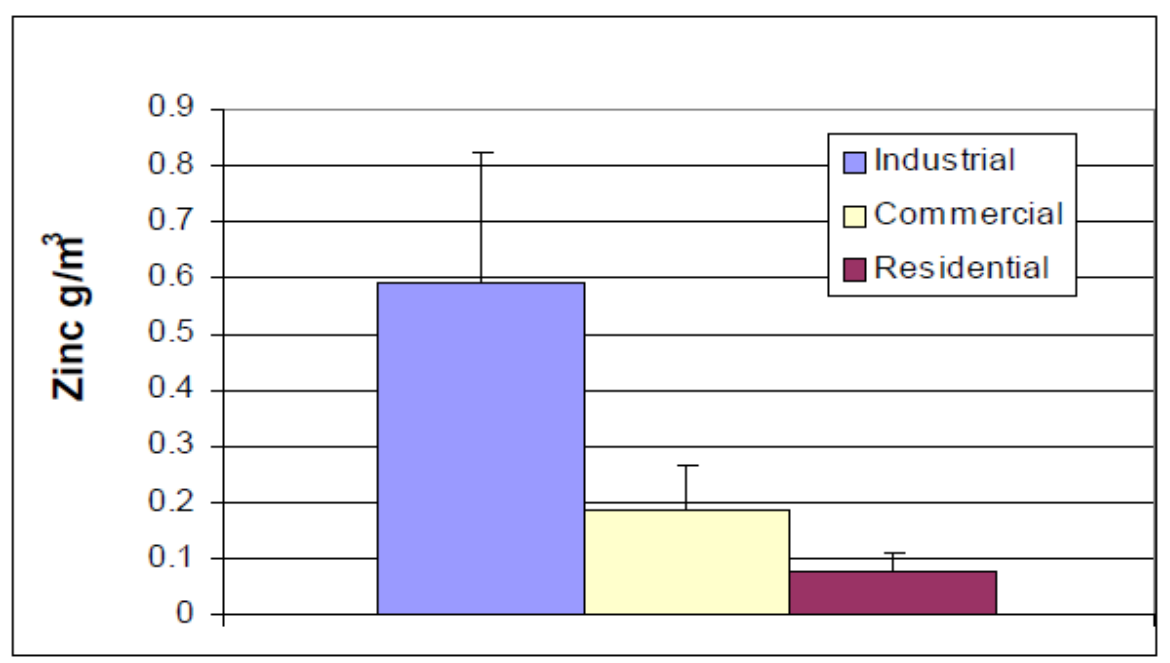

Figure 4.50 The median $\mathrm{Zn}$ concentration, standard error and land-use for the monitored storm water in six residential sites: Owhiro Stream, Browns Stream, The Parade, McLeod Park, Duck Creek, Grassleas Reserve, and five industrial and commercial sites: Te Roto Drive, Semple Street, Hutt Park Road, Waring Taylor Street, Parkside Road. The figure taken from [7]. 
Dissolved $\mathrm{Zn}$ data compared with the data from Roturua City are comparable, but the Rotorua commercial catchment has a markedly higher concentration than the Wellington commercial catchment (Table 4.2) [6].

Table 4.2 Comparison between the average of the median values for dissolved $\mathrm{Zn}$ concentrations for residential and commercial catchments obtained by this study and median values of the respective catchments in the study conducted in Rotorua.

\begin{tabular}{lllll}
\hline \multicolumn{1}{c}{ Year } & Place & Catchment type & $\begin{array}{c}\text { Dissolved Zn } \\
\text { concentration } \\
{[\mathbf{m g} / \mathbf{L}]}\end{array}$ & Reference \\
\hline 2011 & Wellington & Suburban & 0.072 & This study \\
& & residential & & This study \\
2011 & Wellington & Light residential & 0.050 & {$[6]$} \\
$1999-2001$ & Rotorua City & Residential & 0.033 & This study \\
2011 & Wellington & Commercial & 0.053 & {$[6]$} \\
$1999-2001$ & Rotorua City & Commercial & 0.096 & \\
\hline
\end{tabular}




\subsubsection{First Flush and Composite Samples}

All dissolved $\mathrm{Zn}$ concentrations in first flush and composite samples exceeded the respective sustained toxicity triggers, as shown in Figure 4.51. Average dissolved Zn exceeded the CMC for first flush and composite samples at site 8, and approached this level at sites 1 and 5. The highest $\mathrm{Zn}$ concentrations were observed at site 8 followed by sites 5 and 1 . The first flush effect was exhibited in storm runoff monitored at sites 1, 5, 8, and 9 (Figure 4.51).

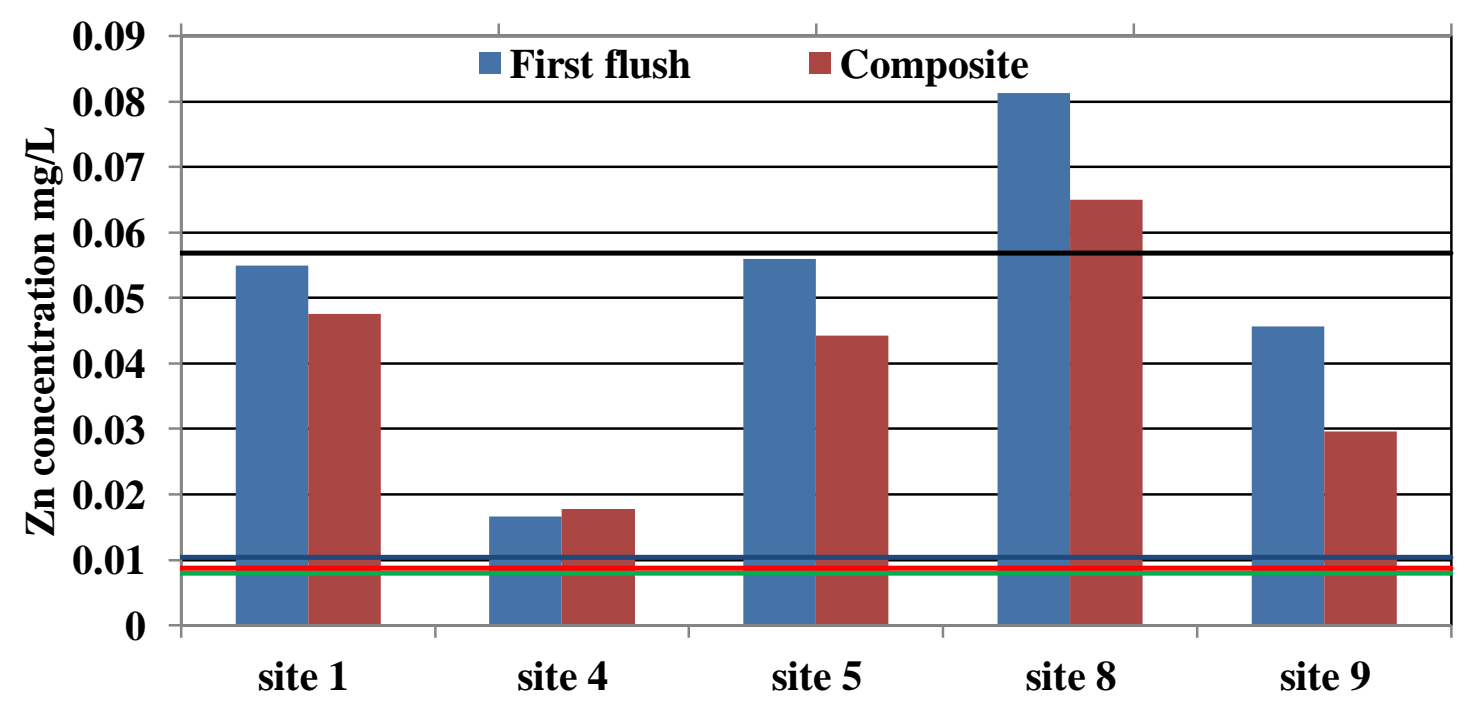

Figure 4.51 The medians for sites 1 and 8, and single data for sites 4, 5 and 9 of dissolved $\mathrm{Zn}$ concentrations in first flush and composite samples. Shown are visual comparisons of Zn concentrations against the ANZECC (2000) TV (green line), HMTVs for Karori Stream (red line), and Porirua Stream (blue line); and (CMC) (black line).

Comparison with previous work shows that the results of this study and data obtained between 2005-2007 by the GWRC,[8], agree on observing first flush effect for dissolved $\mathrm{Zn}$, shown in Figure 4.52. The concentrations of dissolved $\mathrm{Zn}$ in this study however are higher than those reported by the GWRC,[8], in both first flush and composite samples, as shown in Figure 4.52. 


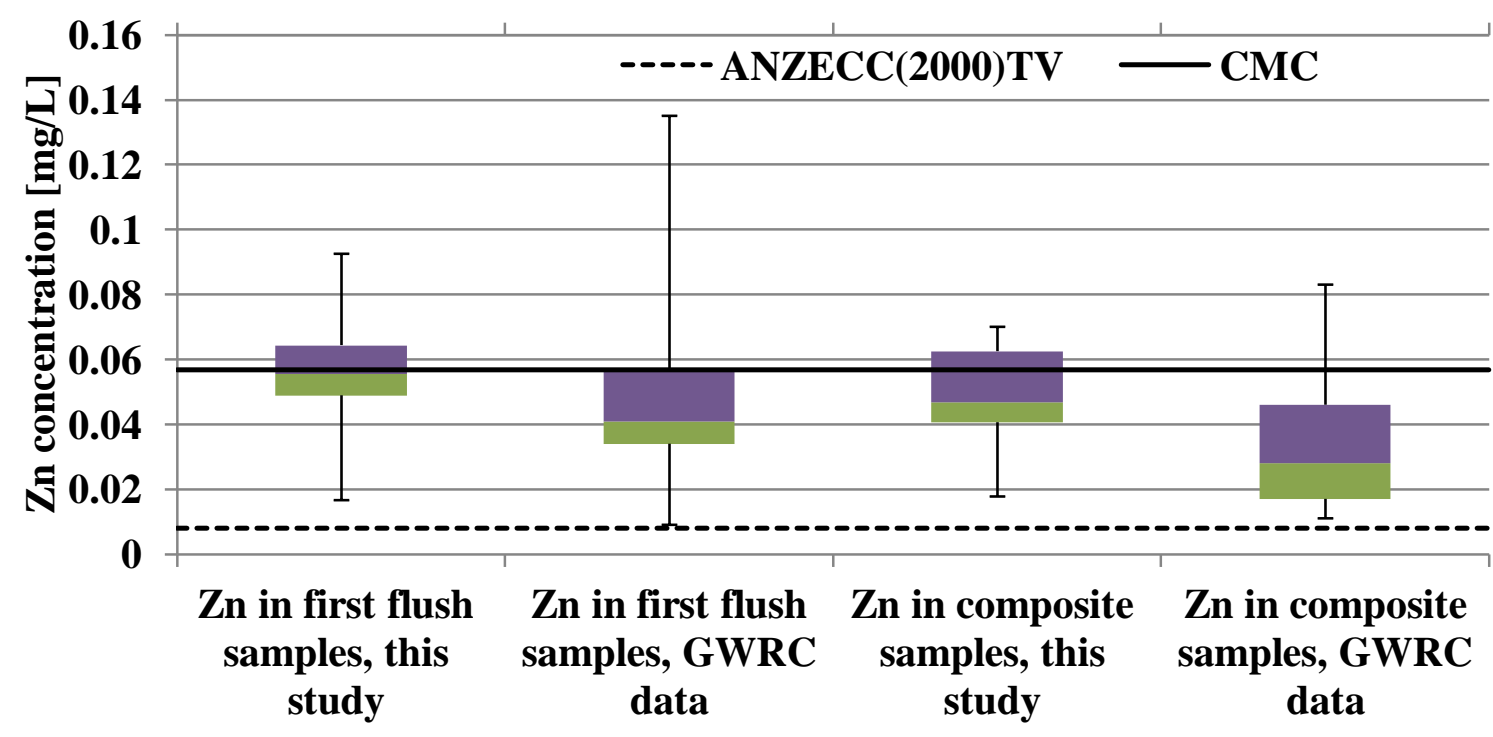

Figure 4.52 ANZECC (2000) TV, CMC and a summary of dissolved Zn concentrations $[\mathrm{mg} / \mathrm{L}]$ in first flush and composite samples by this study and by the GWRC, between 2005-2007 [8]. 


\subsubsection{Summary of Dissolved Zn Concentrations in Base Flow and Storm Runoff Monitoring}

Overall, the medians of dissolved $\mathrm{Zn}$ concentrations in base flow were higher than the respective chronic water quality guidelines at all sites excepting sites of Makara and Ohariu Streams, the rural sites. The median of dissolved $\mathrm{Zn}$ concentrations in storm runoff samples were higher than the corresponding base flow samples, and elevated compared to their sustained toxicity triggers. Similarly to the $\mathrm{Cu}$ results, the highest concentrations were observed at suburban residential catchments, and were lowest for rural catchments; values of commercial and light residential catchments fall in between.

Comparisons of the data with previous work shows comparable concentrations were observed by the GWRC [7], in the Wellington region of residential catchments; however, the concentrations recorded for site 1 in this study tended to be similar to those observed for industrial catchments. Data from Rotorua and this study are of the same order of magnitude.

The first flush effect was observed in five storm runoff events and the concentrations of dissolved $\mathrm{Zn}$ in first flush and composite samples exceeded the CMC at site 8 . The study by the GWRC [8], conducted in the Wellington region, reached the same conclusion, however, higher concentrations were recorded in this study. 


\subsubsection{Dissolved Fe}

\subsubsection{Base flow Samples}

As can be seen in Figure 4.53, all the base flow medians of dissolved $\mathrm{Fe}$ concentrations were below the CTV except at site 5. Because the results of this site were anomalous, site 5 of Kenepuru Stream was further investigated by analysing base flow stream water samples from up and downstream of the sampling site. A total of eight samples were analysed, with a concentration range of $0.39-1.57 \mathrm{mg} / \mathrm{L}$. Some of the samples were obtained directly from springs that drain directly to the Kenepuru Stream, and the samples contained orange clay. It was concluded that the concentration of dissolved $\mathrm{Fe}$ at this stream is naturally elevated. The concentrations of dissolved Fe was reported by Hodder at elevated levels for Ngawha Springs in Taupo, [53], similar to those found in this study for site 5 and they noted that the origin of the elevated level of dissolved Fe concentration is due to hydrothermal activity.

The data provided by the GWRC [34], summarised in Appendix 1, Figure A1.8, for site 10, show that the median of dissolved Fe concentrations was below the CTV which is consistent with this study. However, the median of dissolved $\mathrm{Fe}$ concentrations measured in this study is higher.

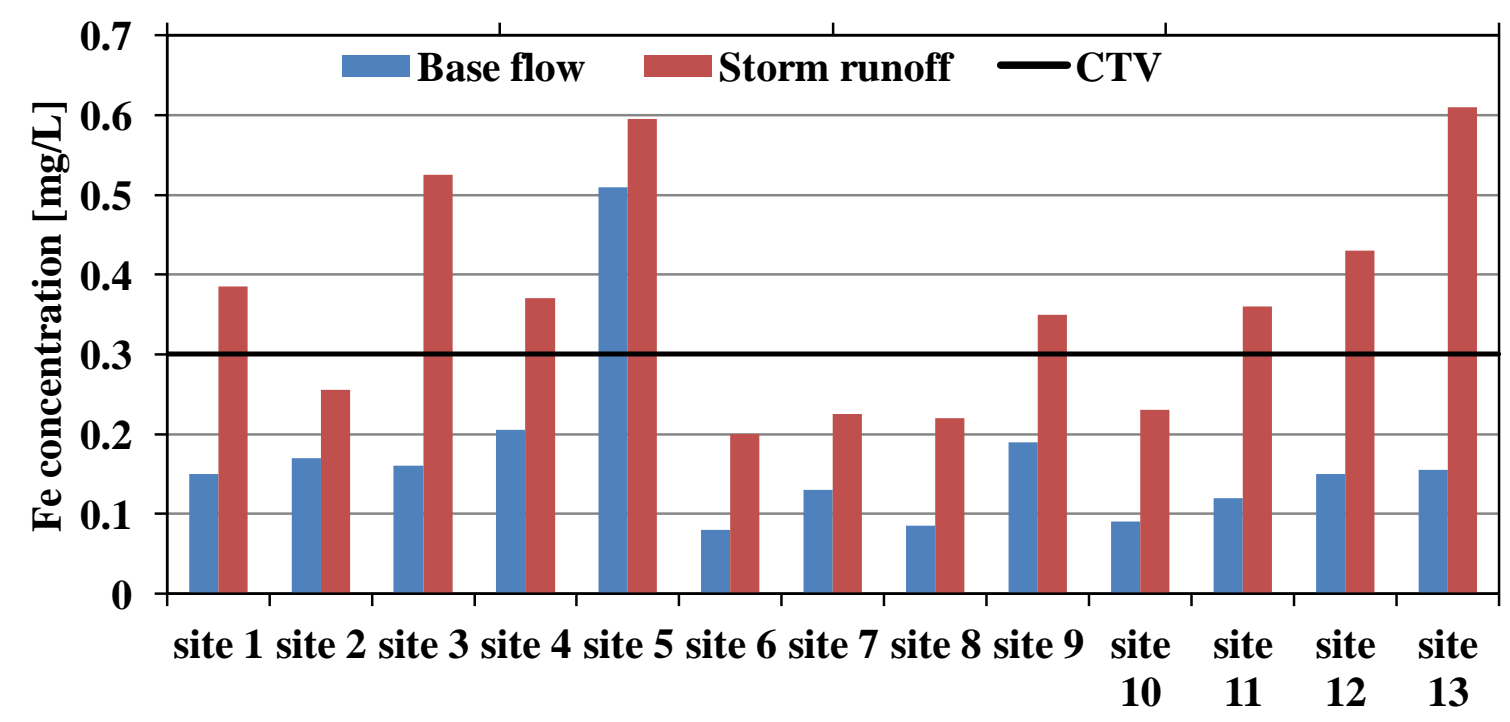


Figure 4.53 The median values for dissolved Fe concentrations in base flow and storm runoff samples from sites 1-13, and visual comparisons between the median values and the CTV.

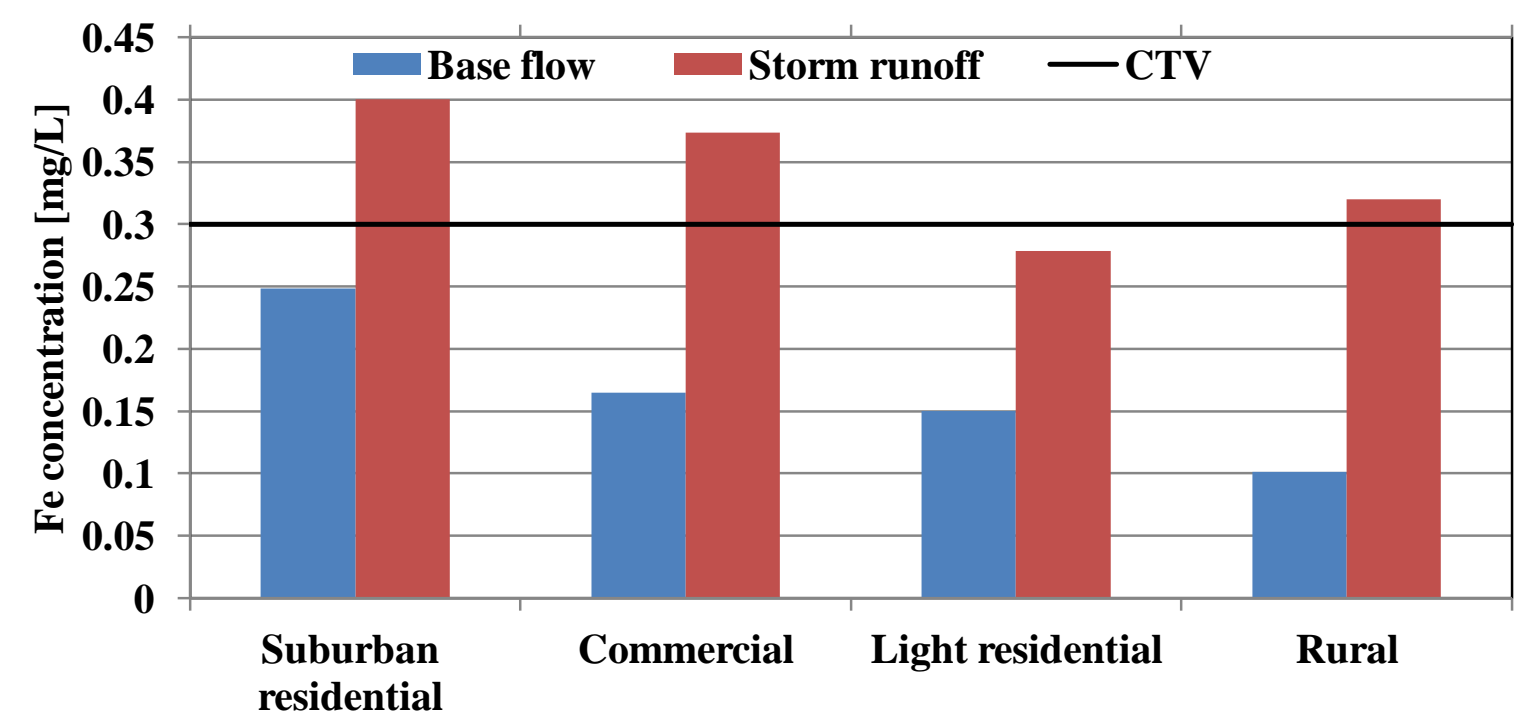

Figure 4.54 The CTV and average of the median values for dissolved $\mathrm{Fe}$ concentrations in base flow and storm runoff samples for suburban residential (sites 1, 5, 8), commercial (sites 3, 4, 7), light residential (sites 2, 9 and 10), and rural sites (sites 6, 11, 12 and 13).

\subsubsection{Storm Runoff Samples}

Figure 4.54 clearly shows the medians of dissolved Fe concentrations were higher in storm runoff than the corresponding base flow samples. The CTV was exceeded in sites $1,3,4,5,9,11,12$, and 13 .

Suburban residential sites had the highest values of dissolved $\mathrm{Fe}$ in storm runoff samples, as shown in Figure 4.54 (remembering that the contribution of site 5 to this figure is not manmade contamination. Rural sites 11, 12, 13 showed high dissolved Fe during runoff events in contrast to what was observed for dissolved $\mathrm{Cu}$ and $\mathrm{Zn}$. $\mathrm{Fe}$ is a key component element in soils and sediments [16]. At these rural sites, there is very little, if any, piping and tunnelling of the streams, so water during runoff has a greater contact with soil and sediment. Samples collected from the rural sites had higher amount of suspended solid (based on visual observation). This might explain the higher concentrations observed. 
The observed elevated dissolved Fe concentrations, particularly those recorded for suburban residential and commercial catchments, could have originated from various sources. Kennedy indicated that $\mathrm{Fe}$ is a common contaminant in accumulated materials in the Wellington region, ranging from 1.64 to $4.76 \%$ [16]. The prevalence of Fe was attributed to the rusting process of iron in buildings and car components, with a little from tyres, raw bitumen and brake pad/dust. The concentrations of $\mathrm{Fe}$ in accumulated dust/particulates in gutter and on road surfaces were higher than what would be expected from soil or sediment samples [16]. Kennedy and Gadd [15] found that samples obtained from New Zealand tyres had the highest median $\mathrm{Fe}$ concentration of $105 \mathrm{mg} / \mathrm{kg}$ when compared with the other analysed samples; brake pads, raw bitumen and road bitumen.

In the GWRC study, [7] , the median for dissolved Fe concentrations of the 11 storm runoff events sampled between June 2002 and September 2004 was 0.08 mg/L (range $<0.02-0.24$ ). This range is markedly lower compared with what has been observed for the respective catchments in this study. Nevertheless, comparable medians of the dissolved Fe concentrations were observed at site 7 of Takapu Stream and site 8 of Karori Stream in both studies.

Dissolved Fe concentrations during runoff events were also compared with Rotorua city data [6]. The concentrations recorded in this study are significantly higher than the corresponding concentrations, as shown in Table 4.3. 
Table 4.3 Comparison between the average of the median values for dissolved Fe concentrations for residential and commercial catchments obtained by this study and median values of the respective catchments in the study conducted in Rotorua.

\begin{tabular}{ccccc}
\hline Year & Place & Catchment type & $\begin{array}{c}\text { Dissolved Fe } \\
\text { concentration } \\
{[\mathbf{m g} / \mathbf{L}]}\end{array}$ & Reference \\
\hline 2011 & Wellington & $\begin{array}{c}\text { Suburban } \\
\text { residential }\end{array}$ & 0.4 & This study \\
2011 & Wellington & Light residential & 0.27 & This study \\
$1999-2001$ & Rotorua City & Residential & 0.04 & {$[6]$} \\
2011 & Wellington & Commercial & 0.37 & This study \\
$1999-2001$ & Rotorua City & Commercial & 0.08 & {$[6]$} \\
\hline
\end{tabular}

\subsubsection{First Flush and Composite Samples}

Figure 4.55 shows that dissolved Fe concentrations at site 1 and site 5 for first flush and composite samples exceeded the CTV. As noted earlier, the elevated dissolved Fe concentration at site 5 is probably natural. First flush monitoring showed that one event at site 5 of Kenepuru Stream and two events at site 8 of Karori Stream exhibited first flush effect. In general, the first flush of dissolved $\mathrm{Fe}$ is weak compared with dissolved $\mathrm{Cu}$ and $\mathrm{Zn}$. 


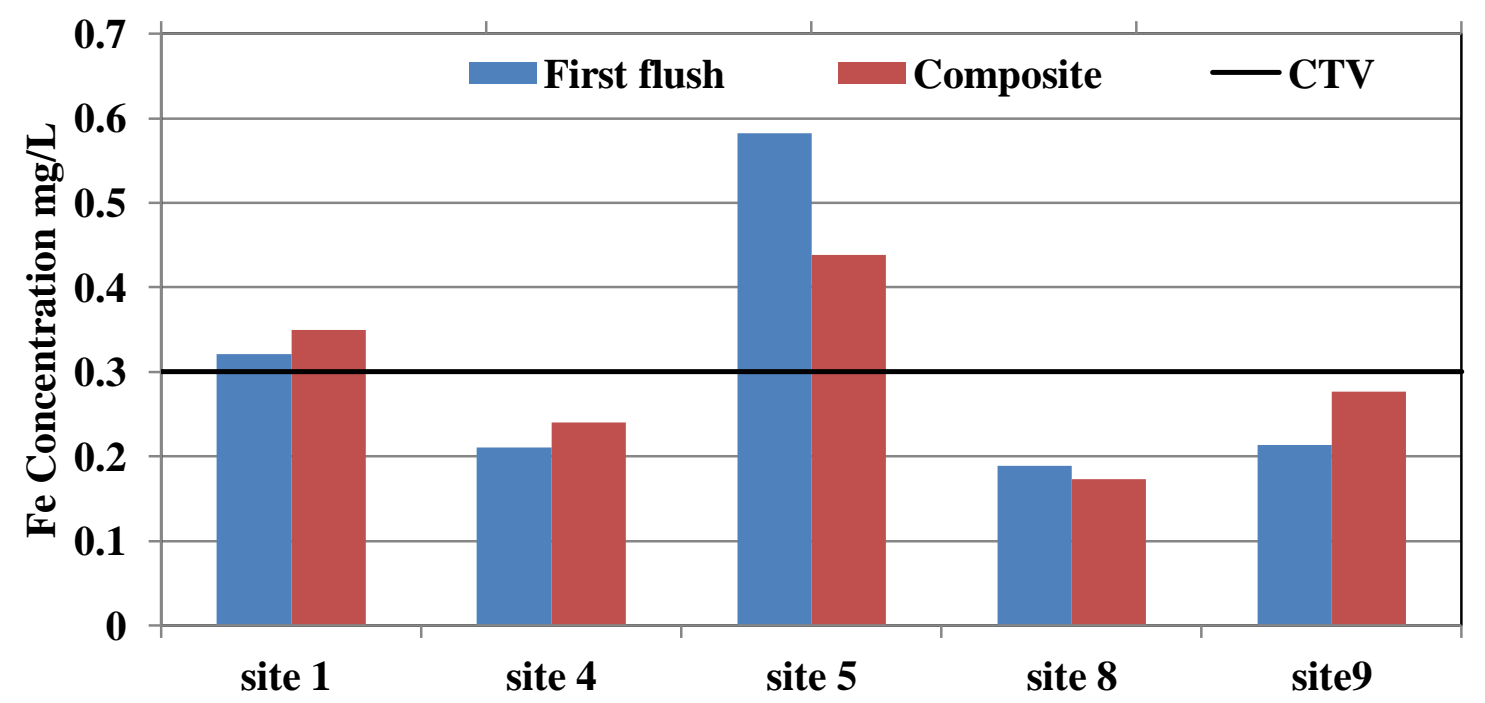

Figure 4.55 The CTV and the median values for site 1 and site 8 , and a single data of dissolved Fe concentrations for sites 4, 5, and 8 in first flush and composite samples.

\subsubsection{Summary of Dissolved Fe Concentrations in Base Flow and Storm Runoff Monitoring}

Base flow median concentrations of dissolved $\mathrm{Fe}$ at the monitored catchments were below the CTV except site 5 of Kenpuru Stream which is probably not an anthropogenic contribution. The concentrations of dissolved Fe were higher in storm runoff than the base flow. Dissolved Fe in storm runoff samples at light residential areas is the only figure that does not exceed the CTV. Three storm runoff events showed the first flush effect, one event at sites 5, and two events at 8. Dissolved Fe was recorded during runoff events at markedly higher levels than those recorded by previous work in the Wellington region and within New Zealand [6-7]. 


\subsubsection{First Flush of Dissolved Metals and Antecedent Dry Weather}

The longest period of dry weather observed in this study was 10 days. Storm water runoff occurring after this period was observed as a first flush at two sites (sites 8 and 9). The antecedent period of dry weather associated with other first flush monitoring events varied from 1 day to 8 days.

It might be expected that the highest concentration of first flush of dissolved metals would appear with runoff events associated with longest preceding period of dry weather [29]. This does not necessarily seem to be true, although the amount of data is limited, considering the monitored storm runoff events at site 1 , as shown in Figure 4.56, the highest concentrations of dissolved $\mathrm{Cu}$ and $\mathrm{Fe}$ for first flush samples amongst the three storm runoff events appeared with the longest preceding period of dry weather followed by the event with only one preceding non raining day and the lowest concentrations were observed with the event associated with five preceding fine days. There was no obvious relation between the concentrations of dissolved $\mathrm{Zn}$ in the three monitored storm runoff events at site 1 in comparison to the other metals. A storm runoff event at site 8 that occurred after 10 days of dry weather, as shown in Figure 4.57, resulted in the highest first flush of dissolved Fe and $\mathrm{Zn}$, but the highest dissolved $\mathrm{Cu}$ concentration was associated with the storm runoff that occurred after 1 day of dry weather. It should be noted that there are other factors that contribute to the natural behaviour of heavy metals in a first flush, such as rainfall intensity, runoff volume and the physical characteristics of the runoff land [30, 54], which were not considered in this study. The results of the first flush of $\mathrm{Zn}$ at site 1 is at agreement with what has been reported by Schriewer and co-authors [55]. They found higher Zn concentrations were associated with low rain intensities, and were independent of the antecedent dry weather period. 


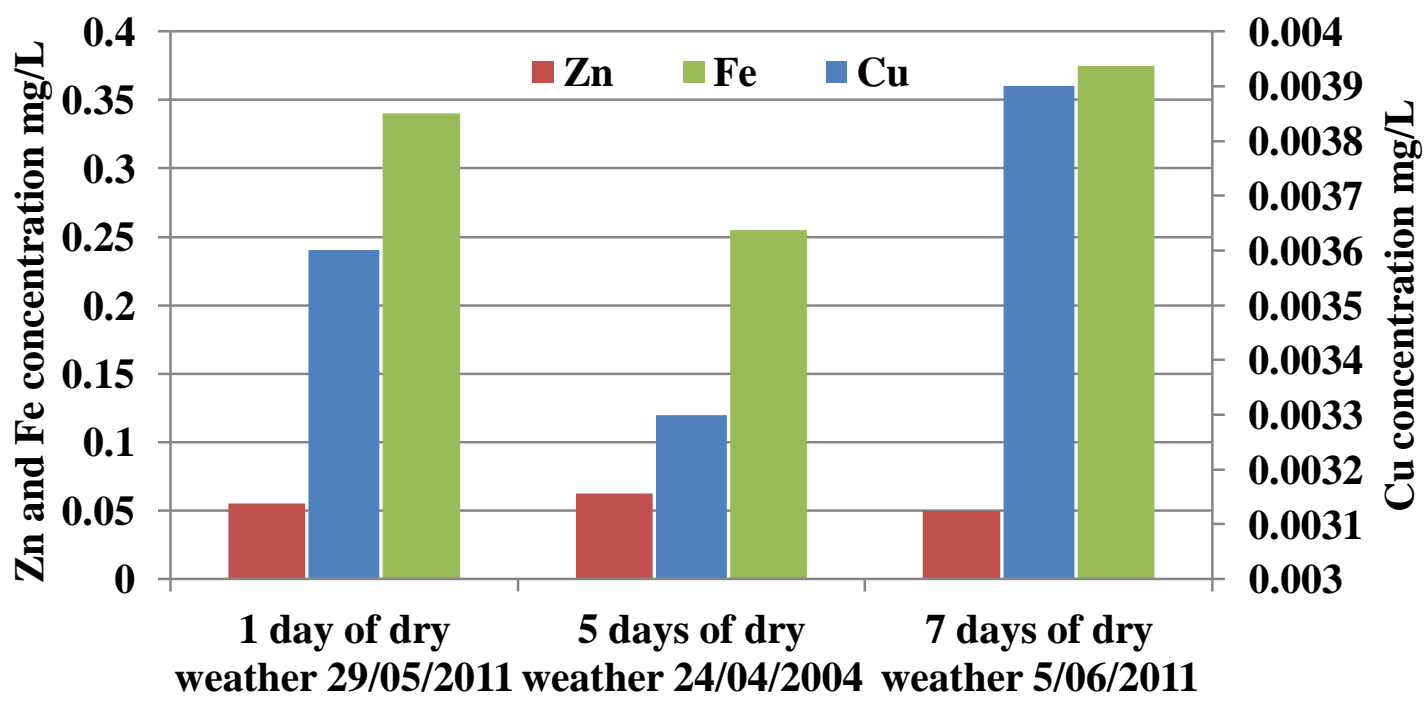

Figure 4.56 Comparison between the concentrations of dissolved $\mathrm{Cu}, \mathrm{Zn}$ and $\mathrm{Fe}$ $[\mathrm{mg} / \mathrm{L}]$ in first flush samples associated with different duration of dry weather at site 1of Porirua Stream.

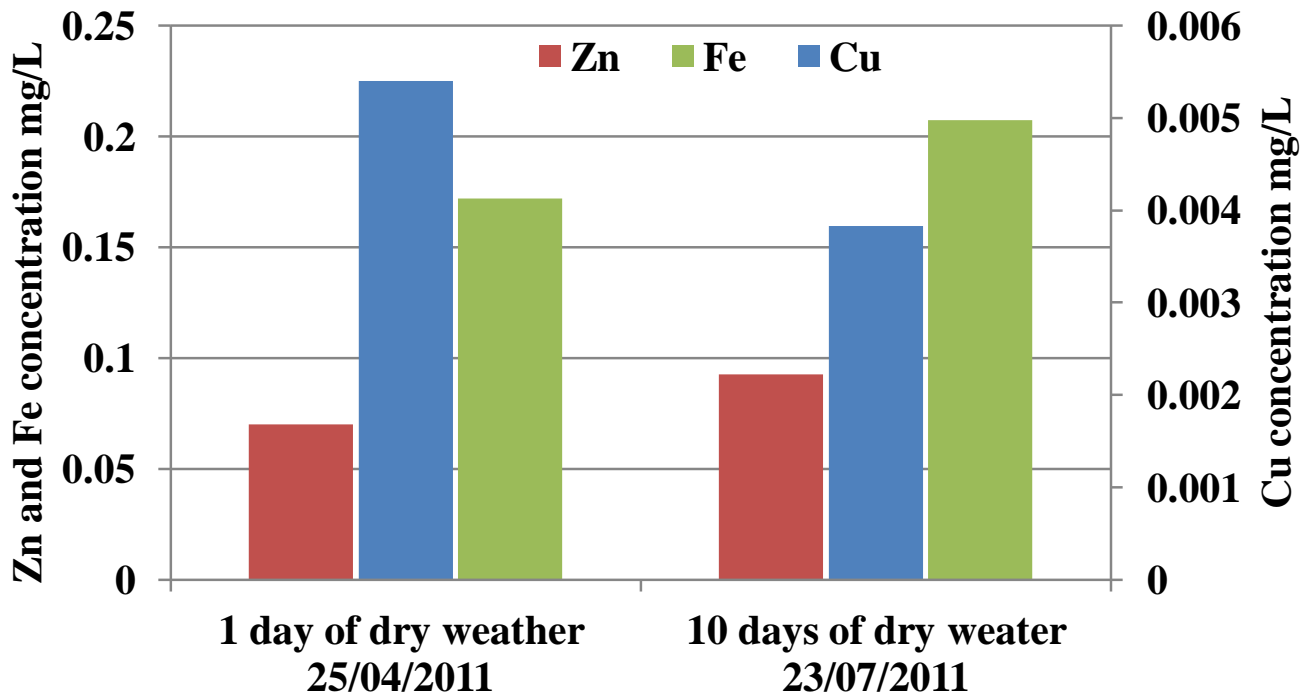

Figure 4.57 Comparison between the concentrations of dissolved $\mathrm{Cu}, \mathrm{Zn}$ and $\mathrm{Fe}$ $[\mathrm{mg} / \mathrm{L}]$ in first flush samples associated with different duration of dry weather at site 8 of Karori Stream. 


\section{Chapter 5}

\section{Investigation of Possible Sources of Dissolved Metals in Storm Water}

\subsection{Atmospheric Rainfall Samples}

Rainfall samples were collected between December 2010 and July 2011 at the main collection site, the roof of second floor of the Laby building, VUW. A total of 24 rainfall events were sampled at Laby building. The data presented here, shown in Figure 5.1 and Figure 5.2, were obtained using the pre-concentration regime or direct analysis on FAAS. The concentrations are given in Table A. 36 in Appendix 1. In addition, there were seven samplings of atmospheric rainfall events at two other locations in the Wellington region, between April and July 2011; Table 5.1 summarises this data.

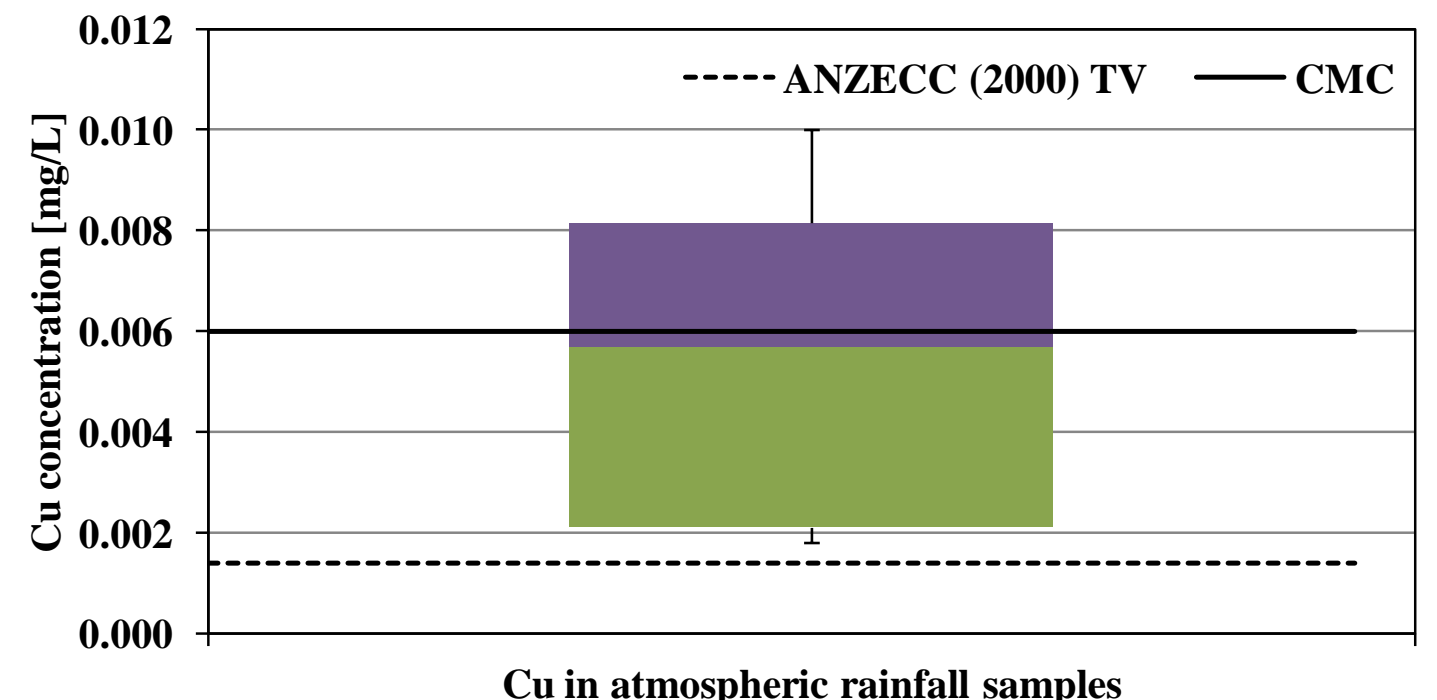

Figure 5.1 Summary of dissolved $\mathrm{Cu}$ concentrations $[\mathrm{mg} / \mathrm{L}]$ in the atmospheric rainfall samples collected at VUW. 


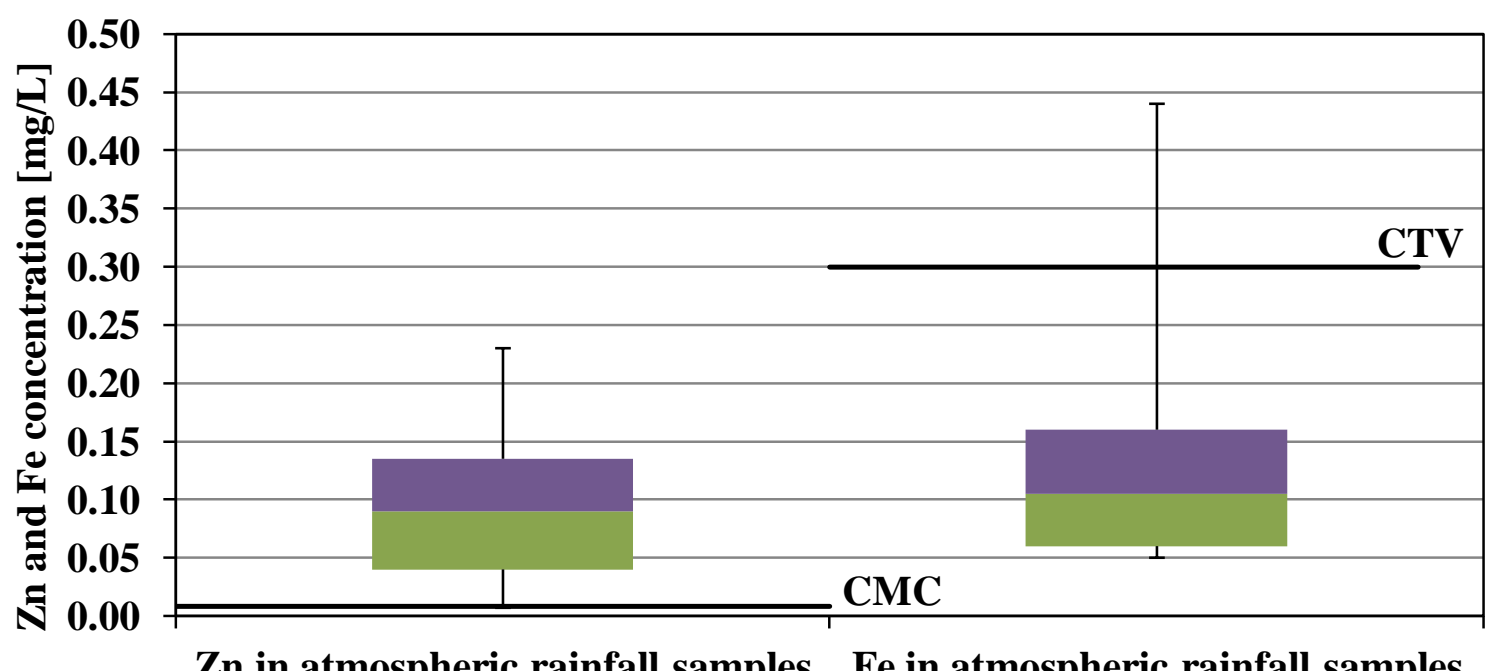

$\mathrm{Zn}$ in atmospheric rainfall samples $\mathrm{Fe}$ in atmospheric rainfall samples

Figure 5.2 Summary of dissolved $\mathrm{Zn}$ and Fe concentrations in the atmospheric rainfall samples collected at VUW.

Table 5.1 Dissolved $\mathrm{Cu}, \mathrm{Zn}$ and $\mathrm{Fe}$ concentrations $[\mathrm{mg} / \mathrm{L}]$ in atmospheric rainfall samples collected at site 13, Takarau Gorge Road and at the top of Mt. Victoria tunnel between April and July 2011.

\begin{tabular}{ccccc}
\hline $\begin{array}{c}\text { Site name and } \\
\text { characteristic }\end{array}$ & $\begin{array}{c}\text { Number } \\
\text { of } \\
\text { samples }\end{array}$ & $\begin{array}{c}\text { Concentration range and median } \\
\text { Cug/L] }\end{array}$ & $\begin{array}{c}\mathbf{Z n} \\
{[\mathbf{m g} / \mathbf{L}]}\end{array}$ & $\begin{array}{c}\text { Fe } \\
{[\mathbf{m g} / \mathbf{L}]}\end{array}$ \\
\hline Site 13, Rural & 4 & $\begin{array}{c}*<0.0012-0.0066 \\
\text { Median }=0.0025\end{array}$ & $\begin{array}{c}0.01-0.08 \\
\text { Median }=0.035\end{array}$ & $\begin{array}{c}\text { Median }=0.05 \\
\text { Mt. Victoria tunnel }\end{array}$ \\
$\begin{array}{c}\text { (urban with high } \\
\text { traffic volume) }\end{array}$ & 3 & $0.0045-0.03$ & $0.13-0.25$ & $<0.045-0.06$ \\
\hline
\end{tabular}

*: Dissolved $\mathrm{Cu}$ in two samples were below the enhanced detection limit of $\mathrm{Cu}$. **: one sample for dissolved Fe below the detection limit of Fe.

Rainwater has no specific toxicity guidelines for heavy metals. The ANZECC (2000) TV, CMC, and CTV would give an indication of contamination levels; therefore, they were used to assess rainwater. 
To the best of our knowledge, none of the existing local (in New Zealand) or international storm water literature has considered rainfall as a contributor to the contamination by heavy metals in streams. In most cases the presence of metal contamination was attributed to runoff from roofs and impervious surfaces [1-2, 1214, 7-8, 29, 32, 35-36]. Rainwater has been recognised as a contributor to metal pollution in drinking water from roof harvesting systems. The data from our rainwater samples clearly illustrates the following points:

1) The median dissolved $\mathrm{Cu}$ and $\mathrm{Zn}$ concentrations in rainwater samples are higher than the ANZECC (2000) TV values.

2) The median of dissolved Fe concentrations was lower than the CTV.

3) The median of dissolved $\mathrm{Cu}$ concentrations was almost equal to and the median of dissolved $\mathrm{Zn}$ concentrations was higher than the CMCs.

4) Higher concentrations of dissolved $\mathrm{Cu}$ and $\mathrm{Zn}$ were associated with longer periods of dry weather before the rainfall events.

5) Comparison of the different sampling sites shows that the highest median dissolved $\mathrm{Cu}$ and $\mathrm{Zn}$ concentrations were in samples collected from Mt. Victoria tunnel, followed by VUW. The results are in agreement with what was found by Davy who measured metal concentrations of airborn particulate matter [56]. He found the concentrations of $\mathrm{Cu}, \mathrm{Zn}$ and $\mathrm{Fe}$ in airborne particulates were higher at the Mt. Victoria tunnel than those for residential and rural sites (refer to Table 5.2). In Auckland, Simmons et al. [32] found dissolved $\mathrm{Cu}$ concentrations in drinking water samples, collected by roof harvesting systems, were higher at urbanised sites than the samples from rural sites. Huston and co-workers [57] in Australia noted that rainfall contributed to dissolved $\mathrm{Cu}, \mathrm{Zn}$ and $\mathrm{Fe}$ concentrations found in drinking water samples collected by roof harvesting systems. 
As mentioned in point 5, the concentrations and composition of airborne particulate matter in the Wellington region have been studied by Davy [56]. In that study, it was concluded various sources contributed to $\mathrm{PM}_{2.5}$ and $\mathrm{PM}_{10}{ }^{10}$ aerosols in the Wellington region. Aerosol concentration and elemental composition varied, depending on the site (Table 5.2).

Table 5.2 Average of the concentrations ${ }^{11}$ of $\mathrm{Cu}, \mathrm{Zn}$ and $\mathrm{Fe}$ in airborne particulate $\mathrm{PM}_{2.5}$ and $\mathrm{PM}_{10}$ [56].

\begin{tabular}{|c|c|c|c|c|}
\hline Site name & $\begin{array}{c}\text { Site } \\
\text { characteristics }\end{array}$ & $\begin{array}{c}\mathrm{Cu} \\
{\left[\mathrm{ng} / \mathrm{m}^{3}\right]}\end{array}$ & $\begin{array}{c}\mathbf{Z n} \\
{\left[\mathrm{ng} / \mathbf{m}^{3}\right]}\end{array}$ & $\begin{array}{c}\mathbf{F e} \\
{\left[\mathrm{ng} / \mathrm{m}^{3}\right]}\end{array}$ \\
\hline Bering Head & Rural & Not recorded & Not recorded & 24 \\
\hline Masterton & Rural residential & 6 & 11 & 84 \\
\hline $\begin{array}{c}\text { Mt Victoria } \\
\text { Tunnel }\end{array}$ & $\begin{array}{c}\text { Urban with high } \\
\text { traffic }\end{array}$ & 179 & 121 & 2564 \\
\hline Upper Hutt & $\begin{array}{l}\text { Residential with } \\
\text { light industrial }\end{array}$ & 2 & 6 & 49 \\
\hline Lower Hutt & Industrial area & 3 & 28 & 163 \\
\hline
\end{tabular}

As noted in the experimental section, Chapter 3, metals in this study were measured after filtrating the samples using $0.45 \mu \mathrm{m}$ filters. Consequently, any $\mathrm{PM}_{2.5}$ and $\mathrm{PM}_{10}$ might be able to pass through the pores of the filter. Alternatively, the metals attached to the airborne aerosol may be soluble in water.

It is concluded that atmospheric rainwater contains dissolved concentrations of $\mathrm{Cu}$ and $\mathrm{Zn}$ that contribute to the concentrations of the metals in storm water. The median of dissolved Fe concentrations were found to be below the CTV.

\footnotetext{
${ }^{10} \mathrm{PM}_{2.5}$ and $\mathrm{PM}_{10}$ : particulate matter with aerodynamic diameters less than 2.5 and $10 \mu \mathrm{m}$ respectively.

11 The concentrations were reported separately for each particle size. In the table, the numbers are the sum of the values for both $\mathrm{PM}_{2.5}$ and $\mathrm{PM}_{10}$.
} 


\subsection{Roof Runoff Samples}

A total of 28 roof runoff samples were collected and analysed for roofs located in the Wellington region mainly commercial roofs in the Wellington Central, Karori, Tawa and Porirua. The samples comprise of:

- 15 samples of galvanised roof runoff, shown in Table A1.37 and visualised in Figures 5.3, 5.4 and 5.5.

- The result of four first flush samples from galvanised roof runoff with their associated delayed runoff samples, shown in Table 5.3.

- Three tile roof runoff samples, shown in Table 5.4.

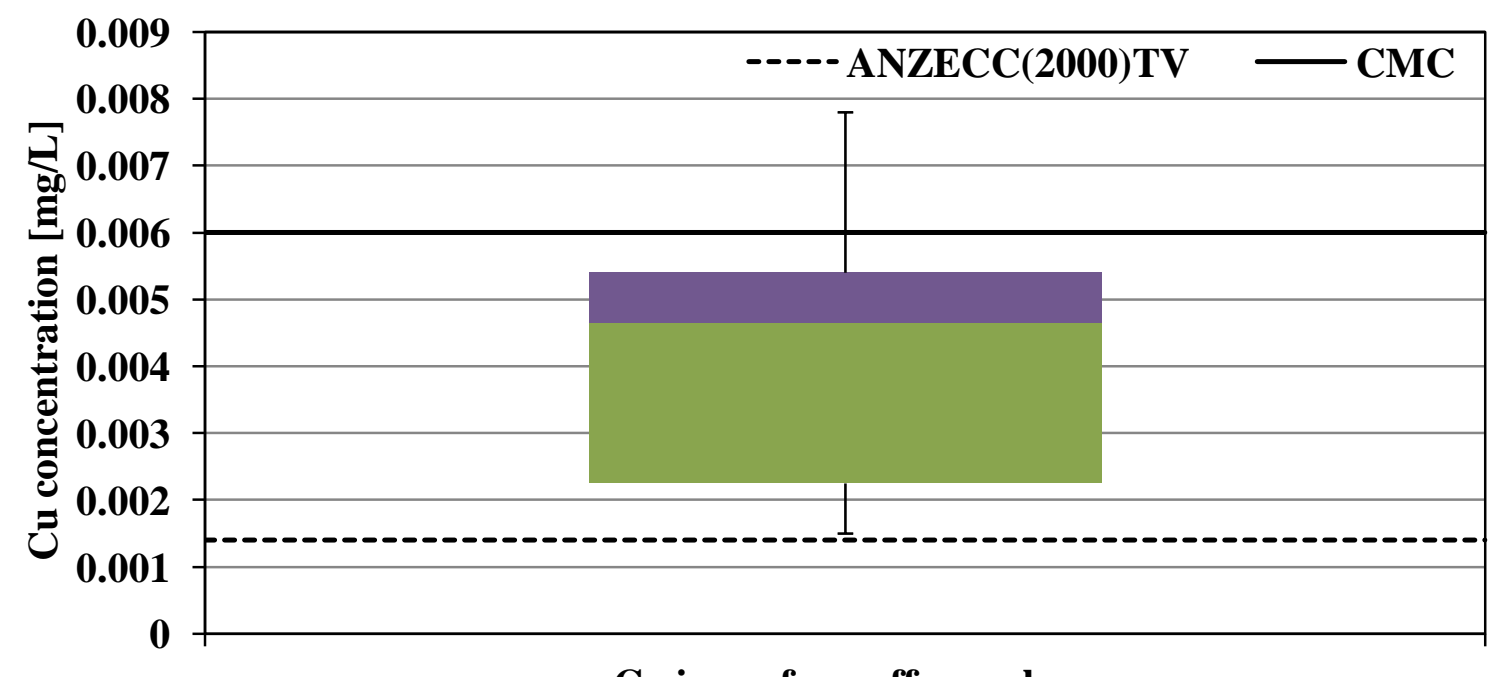

$\mathrm{Cu}$ in roof runoff samples

Figure 5.3 Summary of dissolved $\mathrm{Cu}$ concentrations $[\mathrm{mg} / \mathrm{L}]$ from galvanised roof runoff samples. 


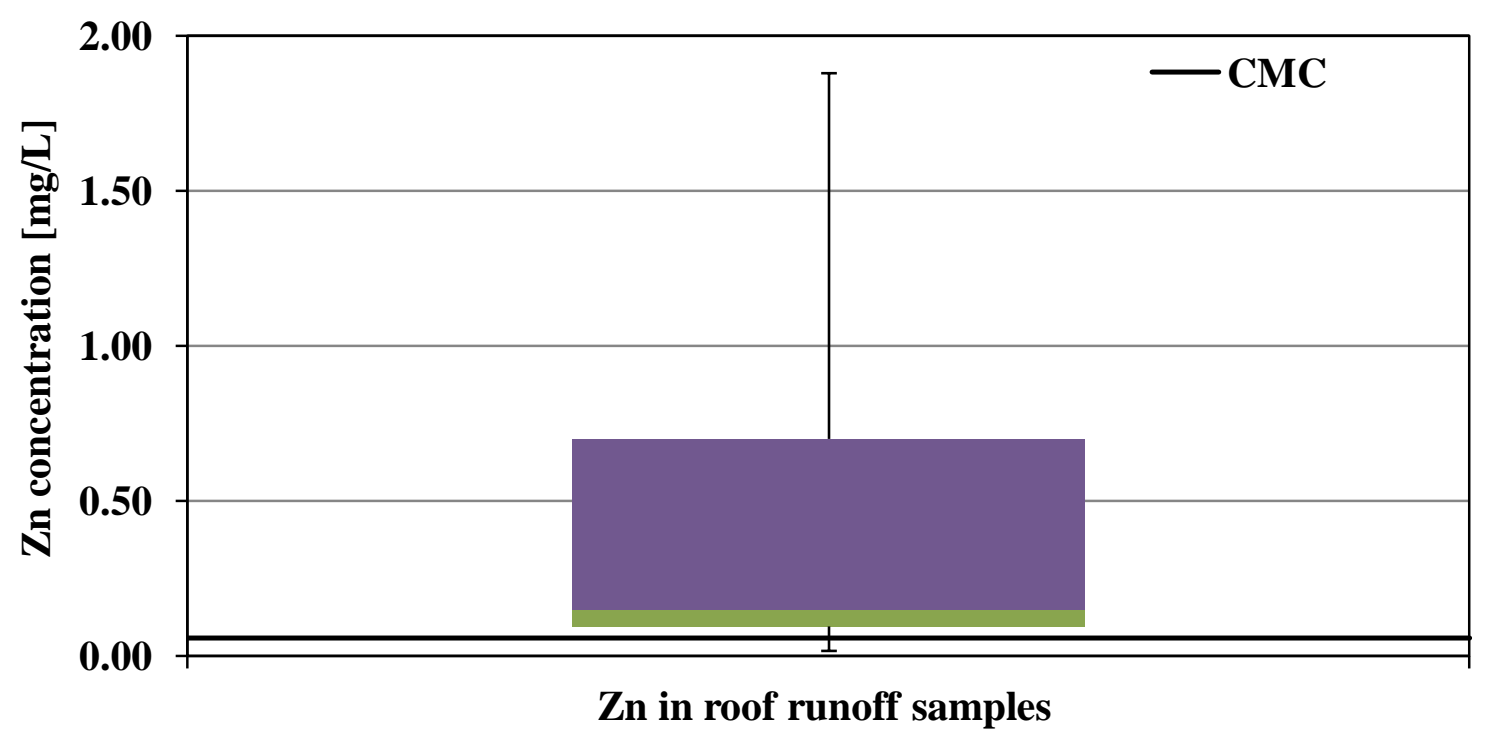

Figure 5.4 Summary of dissolved $\mathrm{Zn}$ concentrations [mg/L] from galvanised roof runoff samples.

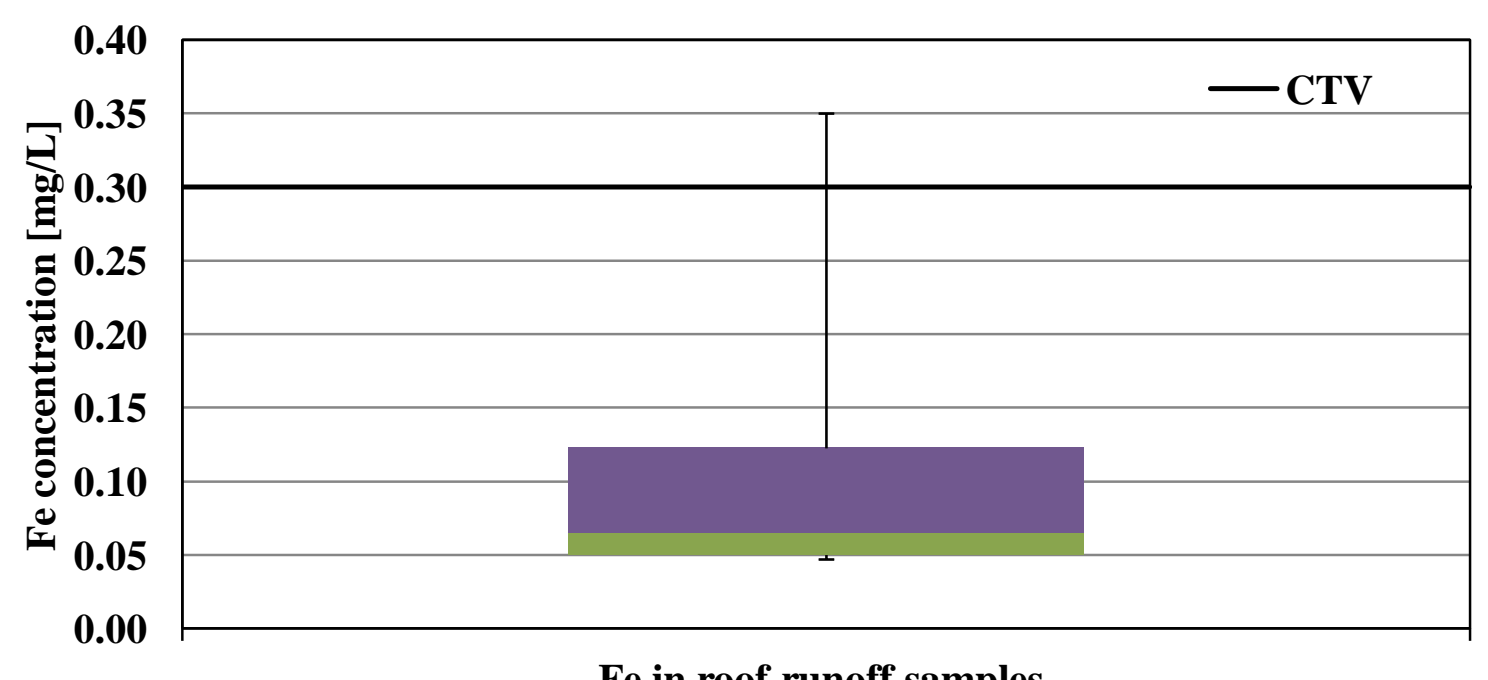

Figure 5.5 Summary of dissolved Fe concentrations $[\mathrm{mg} / \mathrm{L}]$ from galvanised roof runoff samples. 
Table 5.3 Dissolved $\mathrm{Cu}, \mathrm{Zn}$ and Fe concentrations $[\mathrm{mg} / \mathrm{L}]$ in first flush and delayed runoff samples collected from galvanised roofs.

\begin{tabular}{ccccccc}
\hline $\begin{array}{c}\text { Sample } \\
\text { number }\end{array}$ & \multicolumn{2}{c}{$\begin{array}{c}\mathrm{Cu} \\
{[\mathbf{m g} / \mathbf{L}]}\end{array}$} & \multicolumn{2}{c}{$\begin{array}{c}\mathbf{Z n} \\
{[\mathrm{mg} / \mathrm{L}]}\end{array}$} & \multicolumn{2}{c}{$\begin{array}{c}\text { Fe } \\
{[\mathrm{mg} / \mathrm{L}]}\end{array}$} \\
& First flush & Delayed & First flush & Delayed & First flush & Delayed \\
\hline 1 & 0.0099 & $<0.0012$ & 0.28 & 0.28 & 0.88 & $<0.045$ \\
2 & 0.0042 & $<0.0012$ & 0.29 & 0.025 & 0.26 & $<0.045$ \\
3 & 0.0324 & 0.0021 & 0.9 & $\mathbf{1 . 5 6}$ & $<0.045$ & $<0.045$ \\
4 & 0.0021 & 0.0036 & 1.37 & 0.15 & $<0.045$ & $<0.045$ \\
\hline
\end{tabular}

Table 5.4 Dissolved $\mathrm{Cu}, \mathrm{Zn}$ and $\mathrm{Fe}$ concentrations $[\mathrm{mg} / \mathrm{L}]$ in samples collected from tile roof runoff.

\begin{tabular}{cc} 
Metal & $\begin{array}{c}\text { Concentration range } \\
{[\mathrm{mg} / \mathrm{L}]}\end{array}$ \\
\hline $\mathrm{Cu}$ & $<0.0012-0.0024$ \\
$\mathrm{Zn}$ & $0.03-0.06$ \\
$\mathrm{Fe}$ & $<0.045$ \\
\hline
\end{tabular}

ANZECC (2000) TVs, CMCs, and CTV were used to assess metal contamination in roof runoff sample.

As can be seen in Figure 5.3 and Figure 5.4, the median of dissolved $\mathrm{Cu}$ and $\mathrm{Zn}$ concentrations were higher than the ANZECC (2000) TVs, and Zn exceeded the CMC. Dissolved Fe concentrations on the other hand, did not exceed the CTV except in one sample. The same conclusion can be drawn from data presented in a study reported by Simmons et al. in Auckland [32]. The data are for potable water collected using roof harvesting systems, however, they reported significantly higher

\footnotetext{
12 The concentration in delayed sample is higher than the concentration in first flush sample which could be a result of roof corrosion rather than accumulated particulates.
} 
median dissolved $\mathrm{Cu}$ and $\mathrm{Zn}$ concentrations $(0.06,0.4 \mathrm{mg} / \mathrm{L}$ respectively) than those measured in this study.

Tile roof samples contained less dissolved $\mathrm{Cu}$ and $\mathrm{Zn}$ concentrations than those observed from galvanised roof runoff samples, as shown Table 5.4. Yaziz et al., who studied the variations in rainwater quality (several water contaminants including heavy metals) from roof catchments in Malaysia [30], demonstrated the same outcome. These concentrations could have been derived from rainfall. Dissolved Fe concentrations were below the detection limit, as shown in Table 5.4.

The concentrations of dissolved metals, particularly $\mathrm{Cu}$ and $\mathrm{Fe}$, in first flush samples were higher than in the corresponding delayed roof runoff samples (except dissolved $\mathrm{Zn}$ in one event where the concentration in the delayed sample is $0.66 \mathrm{mg} / \mathrm{L}$ higher than the concentration in first flush sample), as shown in Table 5.3, suggesting the presence of accumulated material (dust particulates) containing the metal of concern.

The concentrations of dissolved $\mathrm{Cu}$ and $\mathrm{Fe}$ in rainfall, collected at VUW, and in roof runoff samples (all types) are similar, indicating that the roof runoff $\mathrm{Cu}$ and $\mathrm{Fe}$ are mainly derived from rainfall. In contrast, dissolved $\mathrm{Zn}$ concentrations from galvanised roof runoff samples are higher than the atmospheric rainfall samples. This indicates that galvanised roofs are an additional source of dissolved $\mathrm{Zn}$ in storm water, as has been suggested previously [12, 36, 58-60].

\subsection{Paved Surface Runoff Samples}

A total of 16 samples were collected and analysed for runoff from paved surfaces that serve road, parking and entertaining usages. In most cases, the samples were collected from places close to VUW and to the monitored sites. Dissolved $\mathrm{Cu}, \mathrm{Zn}$ and Fe concentrations are presented in Table A1.38, Appendix 1, and visualised below. The result of first flush monitoring is presented in Table A1.39, Appendix 1. 


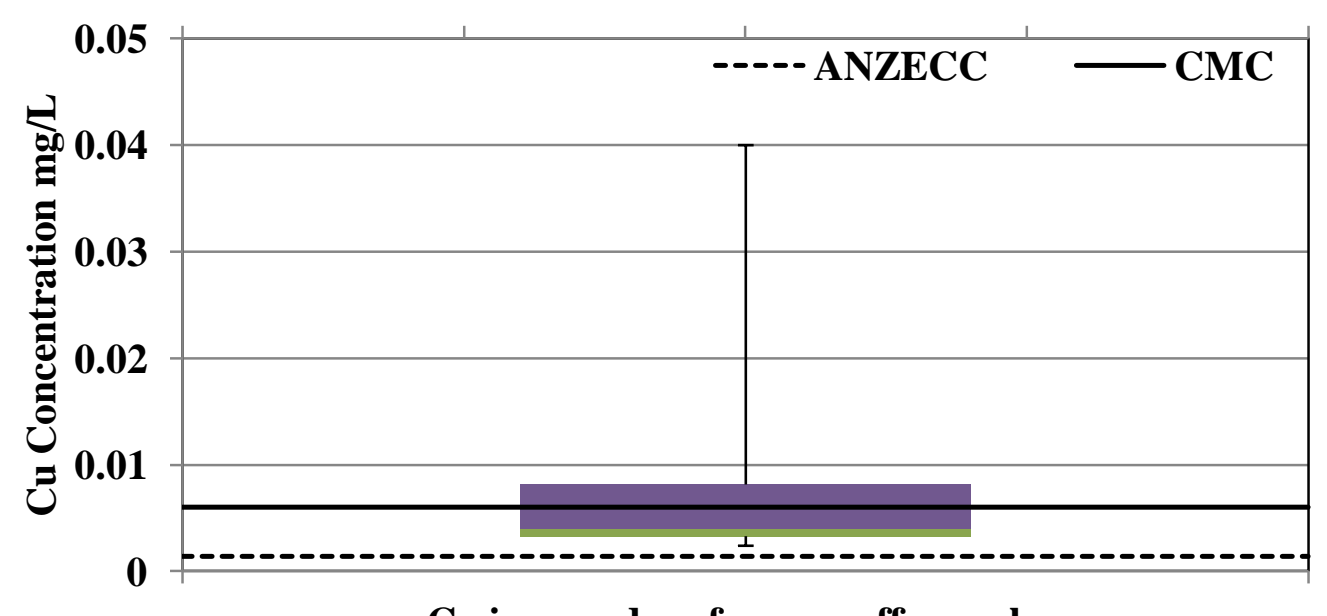

$\mathrm{Cu}$ in paved surface runoff samples

Figure 5.6 Summary of dissolved $\mathrm{Cu}$ concentrations $[\mathrm{mg} / \mathrm{L}]$ in paved surface runoff samples.

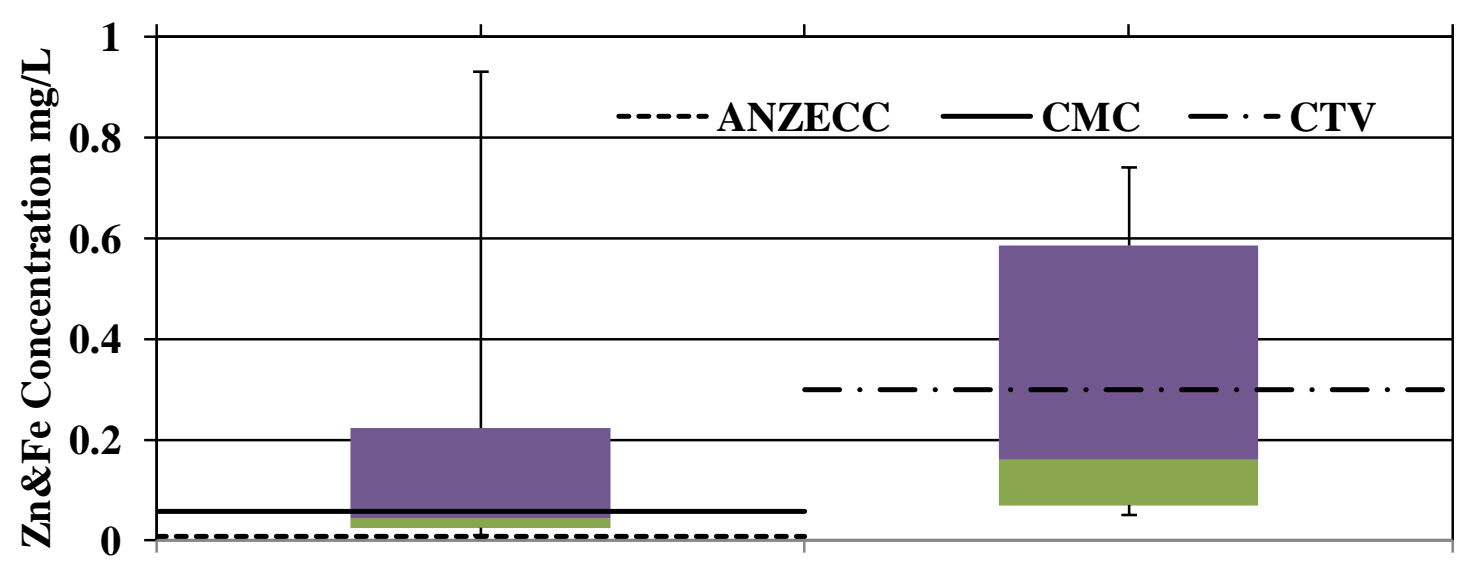

Zn in Paved surface runoff samples Fe in Paved surface runoff samples

Figure 5.7 Summary of dissolved $\mathrm{Zn}$ and Fe concentrations in paved surface runoff samples.

As can be seen in Figure 5.6 and Figure 5.7, the median of dissolved $\mathrm{Cu}$ and $\mathrm{Zn}$ concentrations were above the ANZECC (2000) TVs and below the CMCs. The median of dissolved Fe concentrations did not exceed the CTV.

Runoff from Middleton Road was measured at site 1. Notably, there is probably little roof contribution in this runoff because the draining pipe drains storm runoff from a section of the road, which has no houses on it. The concentrations of dissolved $\mathrm{Cu}$ and $\mathrm{Zn}$ in the first flush sample were 0.0023 and 0.043 and $0.0012,0.040 \mathrm{mg} / \mathrm{L}$ in 
composite sample respectively (for details of this monitoring refer to Table A1. 39, Appendix 1). During the same runoff event, a single first flush sample was obtained at site 1 but from another drainage outlet that discharges road runoff from Wingfield Place which passes through a residential area and could contain roof runoff. The concentrations of dissolved metals were $0.0015,0.17$, and $0.06 \mathrm{mg} / \mathrm{L}$ for $\mathrm{Cu}, \mathrm{Zn}$, and Fe respectively (note that there is no composite sample ${ }^{13}$ ). Dissolved $\mathrm{Zn}$ in the latter first flush sample was 4-fold higher than the other first flush of road runoff. This clearly illustrates the effect of roof material on the amount of dissolved $\mathrm{Zn}$ in storm water.

As mentioned earlier in Section 4.2.2, $\mathrm{Zn}$ has been reported at elevated levels in tyres commonly used in New Zealand and brake pads/dust samples [15]. The mechanical action between tyres and surface causes tyre components to leach into the environment [14]. Sampling of a runoff event from an outdoor field used for gokart racing in Porirua was carried out in this work. The site is located 400 meters upstream from site 4 on Porirua stream. The concentrations of dissolved $\mathrm{Cu}, \mathrm{Zn}$ and Fe in first flush sample were $0.0033,0.93$ and 0.06 and $0.0023,0.33$ and $0.1 \mathrm{mg} / \mathrm{L}$ in composite sample respectively. This is an indication that worn out materials containing these metals accumulated during the dry period, and were flushed off by the first portion of the rain runoff.

The data from paved surface runoff can be compared with similar New Zealand and international studies. The concentrations of dissolved $\mathrm{Cu}$ and $\mathrm{Zn}$ are of the same order of magnitude as the data reported in the study done in the Wellington region by Sherriff [35], the study conducted by Wicke et al. in Christchurch [37] and the study conducted by Stenstrom et al. in California [29].

${ }^{13}$ The water level rose very quickly and the sampling had to be stopped for safety reasons. 


\section{Chapter 6}

\section{Conclusion and recommendations}

This work set out to determine the concentrations of dissolved $\mathrm{Cu}, \mathrm{Zn}$ and $\mathrm{Fe}$ during base and wet weather flow at streams throughout the Wellington region. A secondary objective was to investigate possible sources of heavy metals during rainfall events.

Three dissolved trace metals $\mathrm{Cu}, \mathrm{Zn}$ and $\mathrm{Fe}$ were measured at 13 sites on five streams in base flow conditions and during runoff events in the Wellington region between January and July 2011. More than 240 base flow and 100 wet weather flow samples were analysed for the three dissolved metals. Additionally, 24 rainfall events and runoff from different roof types and paved surface were collected and analysed for dissolved $\mathrm{Cu}, \mathrm{Zn}$, and $\mathrm{Fe}$. The analysis was performed by Flame Atomic Absorption Spectroscopy (FAAS). A pre-concentration procedure, using Chelex-100, was developed and successfully used to enhance the concentrations of dissolved $\mathrm{Cu}$ and $\mathrm{Zn}$.

The medians of dissolved heavy metals, $\mathrm{Cu}, \mathrm{Zn}$, and $\mathrm{Fe}$ all of which are potentially toxic to aquatic life, exceeded the long-term (chronic) toxicity guidelines at one site for $\mathrm{Fe}$, nine sites (69\%) for $\mathrm{Cu}$ and 10 sites (77\%) for $\mathrm{Zn}$ in base flow conditions. Comparison of base flow monitoring data with previously reported concentrations indicated that the concentrations of the studied metals have increased over the last five years.

Storm water (wet weather flow conditions) contained elevated levels of dissolved heavy metals in comparison to base flow concentrations and the recommended guidelines, the ANZECC (2000) TVs and the CTV. Dissolved Cu and Zn exceeded the short-term (acute) toxicity criteria at suburban residential sites. On the other hand, dissolved Fe concentrations exceeded the sustained toxicity exposure trigger at eight sites (61\%). A distinct catchment type contaminant concentration (dissolved $\mathrm{Cu}$ and $\mathrm{Zn}$ ) was observed during storm runoff events with the pattern of suburban residential $>$ commercial $>$ light residential $>$ rural catchment of relative metals 
abundance. Dissolved Fe showed a similar pattern, but the rural concentration was higher than light residential catchments concentration. The observations were attributed to the high vehicle traffic, accumulated particulate materials and corrosion of materials containing heavy metals such as galvanised or copper roofs, gutter systems and building construction materials. The strongest and most obvious first flush effect was observed with dissolved $\mathrm{Cu}$ followed by dissolved $\mathrm{Zn}$; first flush of dissolved Fe however was observed in only three of a total of eight storm runoff events. The concentrations of dissolved metals are in the same order of magnitude as previously reported data for the Wellington region, but higher concentrations were recorded in this work, particularly dissolved Fe. The results are of the same order of magnitude with data sets of other New Zealand regions.

Investigations of possible sources of dissolved heavy metals in storm runoff samples demonstrated that rain water contained markedly elevated dissolved $\mathrm{Zn}$ and smaller $\mathrm{Cu}$ concentrations in comparison to the ANZECC (2000) TVs. The concentrations of dissolved Fe were below the CTV level.

Roof runoff samples had similar dissolved $\mathrm{Cu}$ and $\mathrm{Fe}$ concentration to those recorded in atmospheric rainfall water, but $\mathrm{Zn}$ was found to be higher in galvanised roof runoff so galvanised roof runoff is an additional contributor to dissolved $\mathrm{Zn}$ in storm water. First flush samples from roof runoff had higher concentrations than the delayed runoff samples, indicating the presence of accumulated particulates containing metals. Paved surface runoff samples had concentrations of dissolved $\mathrm{Cu}$ and $\mathrm{Zn}$ higher than chronic toxicity triggers, and the median of the concentrations of these metals did not exceed the acute toxicity guidelines. Median dissolved Fe concentrations were below the CTV criteria. Comparable results have been reported in the New Zealand and international literature.

The outcomes of this project imply that there could be possible adverse impacts to the residing aquatic life as a result of the exposure to high concentration of the studied metals. Accumulation of $\mathrm{Cu}, \mathrm{Zn}$ and $\mathrm{Fe}$ in sediment which leads to sediment toxicity is most likely. 
Monitoring dissolved heavy metals (in particular, $\mathrm{Cu}$ and $\mathrm{Zn}$ ) at Wellington's suburban sites should be continued during dry and wet weathers. Biological toxicity surveys should be undertaken in order to provide a definite decision regarding the possible adverse effects. The amount of $\mathrm{Cu}, \mathrm{Zn}$ and $\mathrm{Fe}$ could be reduced during rainfall events by performing surface painting and maintenance processes. 


\section{References}

1. Lehr, J. and J. Keeley, Water Encyclopedia, Domestic, Municipal, and Industrial Water Supply and Waste Disposal, Vol. 1. 2005, John Wiley \& Sons.

2. Lehr, J. and J. Keeley, Water Encyclopedia, Surface and Agricultrural water, Vol. 3. 2005, John Wiley \& Sons.

3. Wanielista, M.P. and Y.A. Yousef, Stormwater Managment. 1993, USA: John Wiley \& Sons, Inc .

4. Perrie, A. and B. Cockeram, Annual freshwater quality monitoring report for the Wellington Region. Greater Wellintgotn Regional Council, Publication No. GW/EMI-G-10/163, 2010.

5. ANZECC (2000) Australia and New Zealand guidelines for fresh and marine water quality, Volume 8.3, Toxicant. Australian and New Zealand Environment and Conservation Council, Agriculture and Resource Management Council of Australia and New Zealand, Canberra.

6. Macaskill, B., E. Bowman, L. Golding, J. Horrox, and N. Phillips, Rotorua city urban stormwater quality and prediction of environmental impacts. National Institute of Water \& Atmospheric Research Ltd. Technical Addendum. Publication No. HAM2002- 020, 2003.

7. Kingett Mitchell Ltd, Assessment of Urban Stormwater Quality in the Greater Wellington Region. Report No:106620/WRC_Stormwater Review_5.doc, 2005.

8. Milne, J. R. and L. Watts, Stormwater contaminants in urban streams in the Wellington region. Greater Wellington Regional Council, publication No: GW/EMI-T-08/82, 2008.

9. Google-Map, Satellite photos of sites in the Wellington region. Accessed Jun/ 2011: http://maps.google.co.nz

10. Kennedy, P. and S. Sutherland, Urban Sources of Copper, Lead and Zinc. Auckland Regional Council, Technical Report 2008/023.

11. ANZECC (2000) Australia and New Zealand guidelines for fresh and marine water quality, Volume 1, The guidelines. Australian and New Zealand 
Environment and Conservation Council, Agriculture and Resource Management Council of Australia. and New Zealand, Canberra.

12. Boller, M, Tracking heavy metals reveals sustainability deficits of urban drainage systems. Water Science and Technology, 1997, 35(9): p. 77-87.

13. Terzakis, S., M. S. Fountoulakis, I. Georgaki, D. Albantakis, I. Sabathianakis, A. D. Karathanasis, N. Kalogerakis, T. Manios, Constructed wetlands treating highway runoff in the central Mediterranean region. Chemosphere, 2008, 72(2): p. 141-149.

14. Butcher, S. S and R. J. Charlison, An Introduction to Air Chemistry. 1972, New York: Academic Press, Inc.

15. Kennedy, P. and J. Gadd, Preliminary Examination of Trace Elements in Tyres, Brake Pads and Road Bitumen in New Zealand. Kingett Mitchell Limited, Report No: 84913/inorganic3. 2003.

16. Kennedy, P., Metal in particulate material on road surface. Kingett Mitchell Limited, report No: 84918/Dust7, 2003.

17. Burton, G. A. and R. Pitt, Stormwater Effects Handbook: A Toolbox for Watershed Managers, Scientists, and Engineers.2002, New York: CRC Press.

18. Rose, S. and J. A. Shea, Chapter 6 Environmental geochemistry of trace metal pollution in urban watersheds, in Developments in Environmental Sciences, R. D. Dibyendu Sarkar and H. Robyn, Editors. 2007, Elsevier. p. 99-131.

19. Fitzpatrick, M., A review of the ANZECC 2000 trigger values for zinc. New Zealand Water \& Waste Association, Stormwater Conference, Rotorua, 2008.

20. Taylor, T. and J. Marks, Water hardness information for Porirua, Makara and Karori Streams, Personal Communication, 2011.

21. Kingett Mitchell Limited. Aquatic ecology and stream management groups for urban streams in the Wellington Region, Publication No: 104098/ Wellington Urban Stream Ecology .

22. Krajewsk, J. L., C. Chebbo, and A. Saget, Distribution of pollutant mass vs volume in storm water discharges and the first flush phenomenon. Water Research, 1998, 32: p. 234-2356.

23. Doyle, K. C., Sizing the first flush and its effect on the storage-reliabilityyield behaviour of rainwater harvesting in Rwanda. Massachusetts Institute of Technology, MSc Thesis, 2008. 
24. Deletic, A., The first flush load of urban surface runoff. Water Research, 1998, 32: p. 2462-2470.

25. Kim, L. H., M. Kayhanian, S. L. Lau and M. K. Stenstrom, A new modelling approach for estimating first flush metal mass loading. Preceeding of Diffuse Pollution Conference Dublin, USA, 2003, p. 38-46.

26. Martinson, D. B. and T. Thomas, Quantifying the first-flush phenomenon. 12th International Rainwater Catchment Systems Conference, New Delhi, India, 2005.

27. Bach, P.M., D.T. McCarthy, and A. Deletic, Redefining the storm water first flush phenomenon. Water Research, 2010, 444: p. 2487 - 2498.

28. Lee, H., S-L. Lau, M. Kayhanian, and M. K. Stenstrom, Seasonal first flush phenomenon of urban storm water discharges. Water Research, 2004, 38 (19) : p.4153-4163.

29. Stenstrom, M. K. and M. Kayhanian, First Flush Phenomenon Characterization. A study prepared for California Department of Transportation Division of Environmental Analysis, report No: CTSW-RT05-73-02.6, 2005.

30. Yaziz, M. I., H. Gunting, N. Sapari and A. W. Ghazali, Variations in rainwater quality from roof catchments. Water Research, 1989, 23(6): p. 761765.

31. Morrow, A. C., R. H. Dunstan, and P. J. Coombes, Elemental composition at different points of the rainwater harvesting system. Science of The Total Environment, 2010, 408(20): p. 4542-4548.

32. Simmons, G., V. Hope, G. Lewis, J. Whitmore and G. Wanzhen, Contamination of potable roof-collected rainwater in Auckland, New Zealand. Water Research, 2001, 35(6): p. 1518-1524.

33. enHealth Council (2004), Guidance on the Use of Rainwater Tanks. Australian Government, Department of Environmental Health, Canberra.

34. Taylor, T. and J. Marks, Unpublished monitoring data of dissolved $\mathrm{Cu}, \mathrm{Zn}$ and Fe at site 9, Makara Peak, Mountain Bike Park, Karori stream. Personal Communication, 2011.

35. Sherriff, J., An Investigation into Water Quality Effects of Transport. Greater Wellington Regional Council, publication No. WRC/RINV-T-98/25,1998. 
36. Timperley, M., B. Williamson, G. Mills, B. Horne and M. Hasan, Sources and loads of metals in urban stormwater. Auckland Regional Council, Technical Publication No. ARC04104, June 2005, AKL2004-070.

37. Wicke.D., T. Cochrane, A. O’Sullivan, J. Hutchinson and E. Funnell, Developing a rainfall contaminant relationship model for Christchurch urban catchments. Proceeding of the Stormwater Conference, Auckland, New Zealand, 2009.

38. Greater Wellington Regional Council, Stormwater management Issues and options for the Wellington Region, 2004.

39. Google-Map, the Wellington region. Accessed July/ 2011: http://maps.google.co.nz/.

40. Greenberg, A. E., L. S. Clescert, and A. D. Eaton, Standard methods for the examination of water and wastewater. 1992, New York: American Public Health Association.

41. Christian, G. D., Analytical Chemistry. 1994, p. 467-480, New York: John Wiley\& Sons, Inc.

42. Dadfarnia, S. and A. M. Haji Shabani, Recent development in liquid phase microextraction for determination of trace level concentration of metals-A review. Analytica Chimica Acta, 2010, 658(2): p. 107-119.

43. Nelissen, S. J. J. and R. V. Grieken, comparison of pre-concentration procedure for trace metals in natural waters. Analytical Chimica Acta, 1979, 111: p. 215-226.

44. Voutsa, D. C., S. K. Fytianos, and T. Kouimtzis, Comparative study on the preconcentration of copper traces in non-saline waters with chelating resins. Fresenius Z Anal Chem 1988, 330: p. 596-599.

45. Harvey, D., Modern Analytical Chemistry. 2000, p. 508-540, New York: McGraw-Hill Companies, Inc.

46. Lee, J. D. and J. M. Lo, Preconcentration of trace-metals in sea-water matrix for differential-pulse anodic-stripping voltammetry. Analytica Chimica Acta, 1994, 287(3): p. 259-266.

47. Mulazimoglu, A. D., I. E. Mulazimoglu, and E. Ozkan, Preconcentration with 1-Nitroso-2-naphthol Complexes on Dowex MWC-1 Resin: Determination of $\mathrm{Cu}$ and $\mathrm{Zn}$ at Trace Level in Drinking Water Samples by ICP-AES. E-Journal of Chemistry, 2009. 6(4): p. 1176-1180. 
48. Chouyyok, W., Y. Shin, J. Davidson, W. D. Samuels, N. H, Lafemina, R. D. Rutledge, G. E. Fryxell, T. Sangvanich and W. Yantasee, Selective Removal of Copper(II) from Natural Waters by Nanoporous Sorbents Functionalized with Chelating Diamines. Environmental Science \& Technology, 2010, 44(16): p. 6390-6395.

49. Narin, I., M. Soylak, L. Elci and M. Dogan, Determination of trace metal ions by AAS in natural water samples after preconcentration of pyrocatechol violet complexes on an activated carbon column. Talanta, 2000, 52(6): p. 1041-1046.

50. Alvarez, M. B., M. E. Malla, and D. A. Batistoni, Performance evaluation of two chelating ion-exchange sorbents for the fractionation of labile and inert metal species from aquatic media. Analytical and Bioanalytical Chemistry, 2004, 378(2): p. 438-446.

51. Bio-Rad Laboratories, Chelex-100 and Chelex 20 Chelating Ion Exchange Resin, Instruction Manual, No: CA 94547, LIT200 Rev B.

52. Konieczka, P. and J. Namiesnik, Quality Assurance and Quality Control in the Analytical Chemical Laboratory: A Practical Approach. 2009, USA: Taylor \& Francis Group.

53. Hodder, A. P. W., Geothermal Waters: A Source of Energy and Metals. New Zealand Institute of Chemistry, 2002.

54. Gnecco, I., C. Berretta, L. G. Lanza and P. La Barbera, Storm water pollution in the urban environment of Genoa, Italy. Atmospheric Research, 2005, 77(1-4): p. 60-73.

55. Schriewer, A., H. Horn, and B. Helmreich, Time focused measurements of roof runoff quality. Corrosion Science, 2008, 50(2): p. 384-391.

56. Davy, P. K., Composition and Sources of aerosol in the Wellington region of New Zealand. Victoria University of Wellington, PhD Thesis, 2007.

57. Huston, R., Y. C. Chan, T. Gardner, G. Shaw and H .Chapman, Characterisation of atmospheric deposition as a source of contaminants in urban rainwater tanks. Water Research, 2009, 43(6): p. 1630-1640.

58. Wei, Q., G. Zhu, P. Wu, L. Cui, K. Zhang, J. Zhou and W. Zhang, Distributions of typical contaminant species in urban short-term storm runoff and their fates during rain events: A case of Xiamen City. Journal of Environmental Sciences, 2010, 22(4): p. 533-539. 
59. Göbel, P., C. Dierkes, and W. G. Coldewey, Storm water runoff concentration matrix for urban areas. Journal of Contaminant Hydrology, 2007, 91(1-2): p. 26-42.

60. Zheng, R., A. Janssens, J. Carmeliet, W. Bogaerts and H. Hens, An evaluation of highly insulated cold zinc roofs in a moderate humid region-part II: corrosion behavior of zinc sheeting. Construction and Building Materials, 2004, 18(1): p. 61-71.

61. Wei, Q., G. Zhu, P. Wu, L. Cui, K. Zhang, J. Zhou, and W. Zhang, Distributions of typical contaminant species in urban short-term storm runoff and their fates during rain events: A case of Xiamen City. Journal of Environmental Sciences, 2010, 22: p. 533-539.

62. Asaf, L., R. Nativ, D. Shain, M. Hassan and S. Geyer, Controls on the chemical and isotopic compositions of urban stormwater in a semi arid zone. Journal of Hydrology, 2004, 294: p. 270-293. 


\section{Appendix 1}

Data and figures from which figures and arguments were constructed the main text body are included below, unless it is already mentioned. In addition, an electronic copy of the raw data is attached to the thesis for further readings.

\section{List of tables}

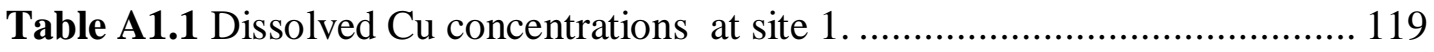

Table A1.2 Dissolved Zn concentrations at site 1......................................... 120

Table A1.3 Dissolved Fe concentrations at site 1.......................................... 121

Table A1.4 Data for the monitored the storm runoff on 24/04/2011 at site 1....... 122

Table A1.5 Data for the monitored the storm runoff on 29/05/2011 on site 1 ...... 123

Table A1.6 Data of the monitored the storm runoff on 05/06/2011 at site1 ........ 124

Table A1.7 Dissolved $\mathrm{Cu}$ concentrations at sites 2 and site 3 .......................... 125

Table A1.8 Dissolved Zn concentrations at sites 2 and site 3.......................... 126

Table A1.9 Dissolved Fe concentrations at sites 2 and site 3......................... 127

Table A1.10 Dissolved $\mathrm{Cu}$ concentrations at site 4. ........................................ 128

Table A1.11 Dissolved Zn concentrations at site 4....................................... 129

Table A1.12 Dissolved Fe concentrations at site 4........................................ 130

Table A1.13 Data of the monitored storm on 23/06/2011 at site 4 ...................... 131

Table A1.14 Dissolved Cu concentrations (at site 5 .......................................... 132

Table A1.15 Dissolved Zn concentrations at site 5......................................... 133

Table A1.16 Dissolved Fe concentrations at site 5 ......................................... 134

Table A1.17 Data for the monitored storm on 18/06/2011 at site 5. ................... 135

Table A1.18 Dissolved Cu concentrations at site 6 and 7 ................................ 136

Table A1.19 Dissolved Zn concentrations at site 6 and 7 ............................... 137

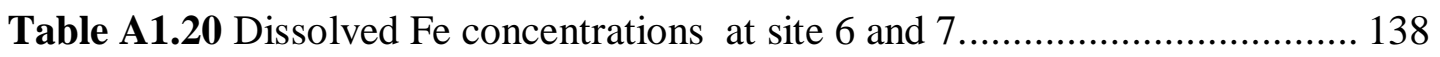

Table A1.21 Dissolved $\mathrm{Cu}$ concentrations at site 8....................................... 139

Table A1.22 Dissolved $\mathrm{Cu}$ concentrations at site 10....................................... 140

Table A1.23 Dissolved $\mathrm{Zn}$ concentrations at site 8 ............................................ 141

Table A1.24 Dissolved Zn concentrations at site 10........................................ 142

Table A1.25 Dissolved Fe concentrations at site 8......................................... 143

Table A1.26 Dissolved Fe concentrations at site 10 ...................................... 144

Table A1.27 Data of the monitored storm on 25/04/2011 at site 8...................... 145

Table A1.28 Data of the monitored storm on 23/07/2011 at site 8 ..................... 146

Table A1.29 Dissolved $\mathrm{Cu}$ concentrations for site 9....................................... 148

Table A1.30 Dissolved Zn concentrations for site 9 .......................................... 149

Table A1.31 Dissolved Fe concentration for site 9 ........................................... 150

Table A1.32 Data of the monitored storm runoff event on 23/07/2011 at site 9... 151

Table A1.33 Dissolved $\mathrm{Cu}$ concentrations at site 11, site12 and site 13............. 152

Table A1.34 Dissolved Zn concentrations at site 11 and site12 and site 13. ........ 153

Table A1.35 Dissolved Fe concentrations for site 11 and site 12 and site 13 ....... 154 
Table A1.36 Dissolved $\mathrm{Cu}, \mathrm{Zn}$ and Fe concentrations in the atmospheric rainfall samples collected at VUW.

Table A1.37 Dissolved $\mathrm{Cu}, \mathrm{Zn}$ and $\mathrm{Fe}$ concentrations in the galvanised roof runoff samples.

Table A1.38 Dissolved $\mathrm{Cu}, \mathrm{Zn}$ and Fe concentrations in paved surfaces runoff off samples.

Table A1.39 Data of the monitored street storm runoff at site 1 on $05 / 06 / 2011 \ldots .157$

\section{List of figures}

Figure A1.1 Temporal variation of dissolved $\mathrm{Cu}, \mathrm{Zn}$ and $\mathrm{Fe}$ concentrations for the monitored storm runoff on 24/04/2011 at site 1

Figure A1.2 Temporal variation of dissolved $\mathrm{Cu}, \mathrm{Zn}$ and $\mathrm{Fe}$ concentrations for the monitored storm runoff on 29/05/2011, at site 1 .

Figure A1.3 Temporal variation of dissolved $\mathrm{Cu}, \mathrm{Zn}$ and $\mathrm{Fe}$ for monitored the storm runoff on $05 / 06 / 2011$ at site 1 .

Figure A1.4 Temporal variation of dissolved $\mathrm{Cu}, \mathrm{Zn}$ and $\mathrm{Fe}$ in the monitored storm runoff on 23/06/2011 at site 4

Figure A1.5 Temporal variation of dissolved $\mathrm{Cu}, \mathrm{Zn}$ and $\mathrm{Fe}$ concentrations for the monitored storm runoff on 18/06/2011 at site 5 .

Figure A1.6 Temporal variation of dissolved $\mathrm{Cu}, \mathrm{Zn}$ and $\mathrm{Fe}$ concentrations for the monitored storm runoff on 25/04/2011 at site 8

Figure A1.7 Temporal variation of dissolved $\mathrm{Cu}, \mathrm{Zn}$ and $\mathrm{Fe}$ concentrations for the monitored storm runoff on 23/07/2011 at site 8

Figure A1.8 Statistical parameters of dissolved $\mathrm{Cu}, \mathrm{Zn}$, and $\mathrm{Fe}$ conducted between January/2008 to Jun/2009 by the GWRC at site 9, Karori Stream at Makara peak, mountain bike Park

Figure A1.9 Temporal variation of dissolved $\mathrm{Cu}, \mathrm{Zn}$ and $\mathrm{Fe}$ for the monitored storm runoff on 23/07/2011 at site 9

Figure A1.10 Temporal variation of dissolved $\mathrm{Cu}, \mathrm{Zn}$ and $\mathrm{Fe}$ for the monitored street storm runoff at site 1 on $05 / 06 / 2011$. 


\section{A1.1 Site 1 Data}

Table A1.1 Dissolved Cu concentrations (mg/L) at site 1 of Porirua Stream.

\begin{tabular}{lcccc}
\hline Sample type & Base flow & First flush & Composite & Storm runoff \\
\hline Number of samples & 19 & 3 & 3 & 0 \\
Number of omitted samples & 7 & 0 & 0.0026 & 4 \\
Minimum [mg/L] & 0.0021 & 0.0033 & 0.0027 & 0.0028 \\
$\mathbf{2 5}^{\text {th }}$ percentile [mg/L] & 0.0029 & 0.0034 & 0.0033 \\
Median [mg/L] & 0.0033 & 0.0036 & 0.0039 & 0.0044 \\
$\mathbf{7 5}^{\text {th }}$ percentile [mg/L] & 0.006 & 0.0037 & 0.0031 & 0.0099 \\
Maximum [mg/L] & 0.012 & 0.0039 & 0.0007 & 0.081 \\
Average [mg/L] & 0.0050 & 0.0036 & 0.0030 & 1.5 \\
Std. dev. [mg/L] & 0.0032 & 2 & Not exceeding \\
$*$ Factor of exceeding the HMTV & 1.8 & Not exceeding & 0.031 \\
$*$ Factor of exceeding the CMC & Not applicable & & \\
\hline
\end{tabular}

* Based on the median values. 
Table A1.2 Dissolved Zn concentrations (mg/L) at site 1 of Porirua Stream.

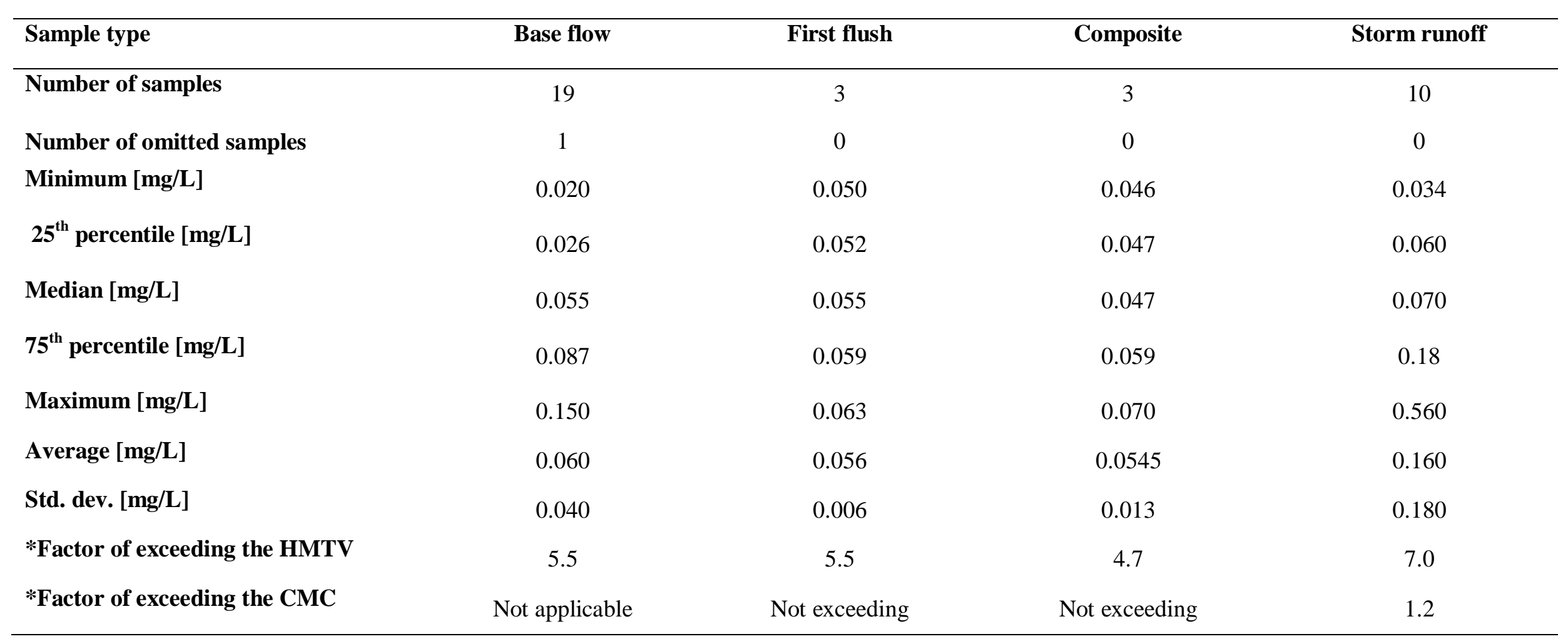

*Based on the median values. 
Table A1.3 Dissolved Fe concentrations (mg/L) at site 1of Porirua Stream.

\begin{tabular}{|c|c|c|c|c|}
\hline Sample type & Base flow & First flush & Composite & Storm runoff \\
\hline Number of samples & 19 & 3 & 3 & 10 \\
\hline Minimum [mg/L] & 0.090 & 0.25 & 0.31 & 0.14 \\
\hline $25^{\text {th }}$ percentile $[\mathrm{mg} / \mathrm{L}]$ & 0.115 & 0.3 & 0.34 & 0.20 \\
\hline Median [mg/L] & 0.15 & 0.34 & 0.36 & 0.38 \\
\hline $75^{\text {th }}$ percentile $[\mathrm{mg} / \mathrm{L}]$ & 0.185 & 0.355 & 0.37 & 0.53 \\
\hline Maximum [mg/L] & 0.39 & 0.37 & 0.38 & 0.73 \\
\hline Average $[\mathrm{mg} / \mathrm{L}]$ & 0.16 & 0.321 & 0.35 & 0.39 \\
\hline Std. dev. $[\mathrm{mg} / \mathrm{L}]$ & 0.07 & 0.06 & 0.035 & 0.11 \\
\hline *Factor of exceeding the CTV & Not exceeding & 1.1 & 1.2 & 1.3 \\
\hline
\end{tabular}

*Based on the median values. 
Table A1.4 Data for the monitored storm runoff on 24/04/2011 at site 1 of Porirua Stream.

\begin{tabular}{cccc}
\hline $\begin{array}{c}\text { Number of } \\
\text { antecedent dry } \\
\text { days }\end{array}$ & \multicolumn{1}{c}{$\begin{array}{l}\text { Metal concentration } \\
\text { [mg/L] }\end{array}$} \\
\hline Sampling time & Cu & $\mathbf{Z n}$ & Fe \\
& 0.0027 & 0.04 & 0.38 \\
9:23 a.m. & 0.0042 & 0.05 & 0.37 \\
9:28 a.m. & 0.0048 & 0.03 & 0.33 \\
9:34 a.m. & 0.0027 & 0.10 & 0.28 \\
9:45 a.m. & 0.0039 & 0.07 & 0.36 \\
10:00 a.m. & & & \\
\hline
\end{tabular}

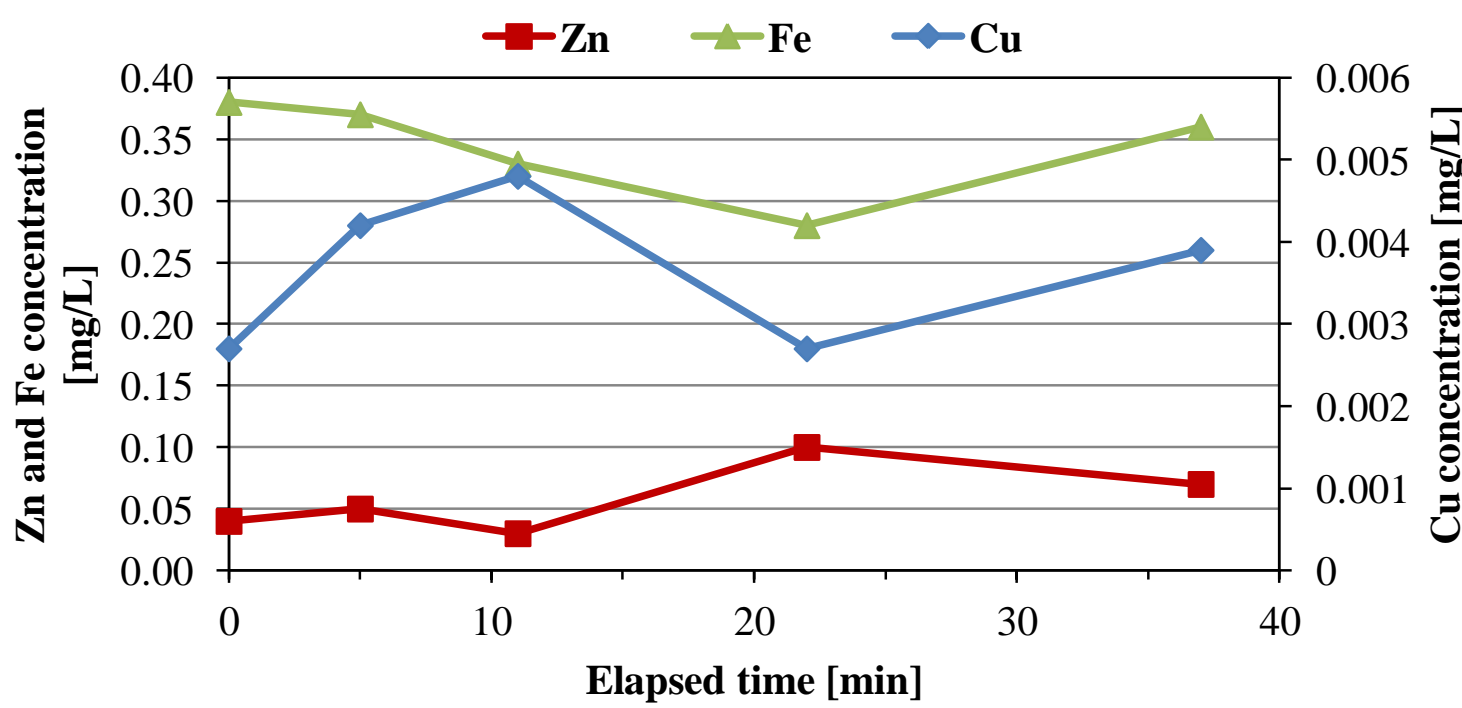

Figure A1.1 Temporal variation of dissolved $\mathrm{Cu}, \mathrm{Zn}$ and $\mathrm{Fe}$ concentrations for the monitored storm runoff on 24/04/2011 at site 1 of Porirua Stream. 
Table A1.5 Data for the monitored storm runoff on 29/05/2011 on site 1 of Porirua Stream.

\section{Number of antecedent} dry days

\section{Metal concentration}

Sampling time

$$
[\mathrm{mg} / \mathrm{L}]
$$

\begin{tabular}{llll} 
& \multicolumn{1}{c}{$\mathbf{C u}$} & \multicolumn{2}{c}{ Fe } \\
\hline 7:10 p.m. & 0.0048 & 0.07 & 0.22 \\
7:15 p.m. & 0.0033 & 0.07 & 0.31 \\
7:20 p.m. & 0.0027 & 0.06 & 0.25 \\
7:25 p.m. & 0.0024 & 0.05 & 0.24 \\
7:30 p.m. & 0.003 & 0.05 & 0.29 \\
7:40 p.m. & 0.0027 & 0.05 & 0.28 \\
7:50 p.m. & 0.0021 & 0.04 & 0.33 \\
8:00 p.m. & 0.0027 & 0.05 & 0.35 \\
\hline
\end{tabular}

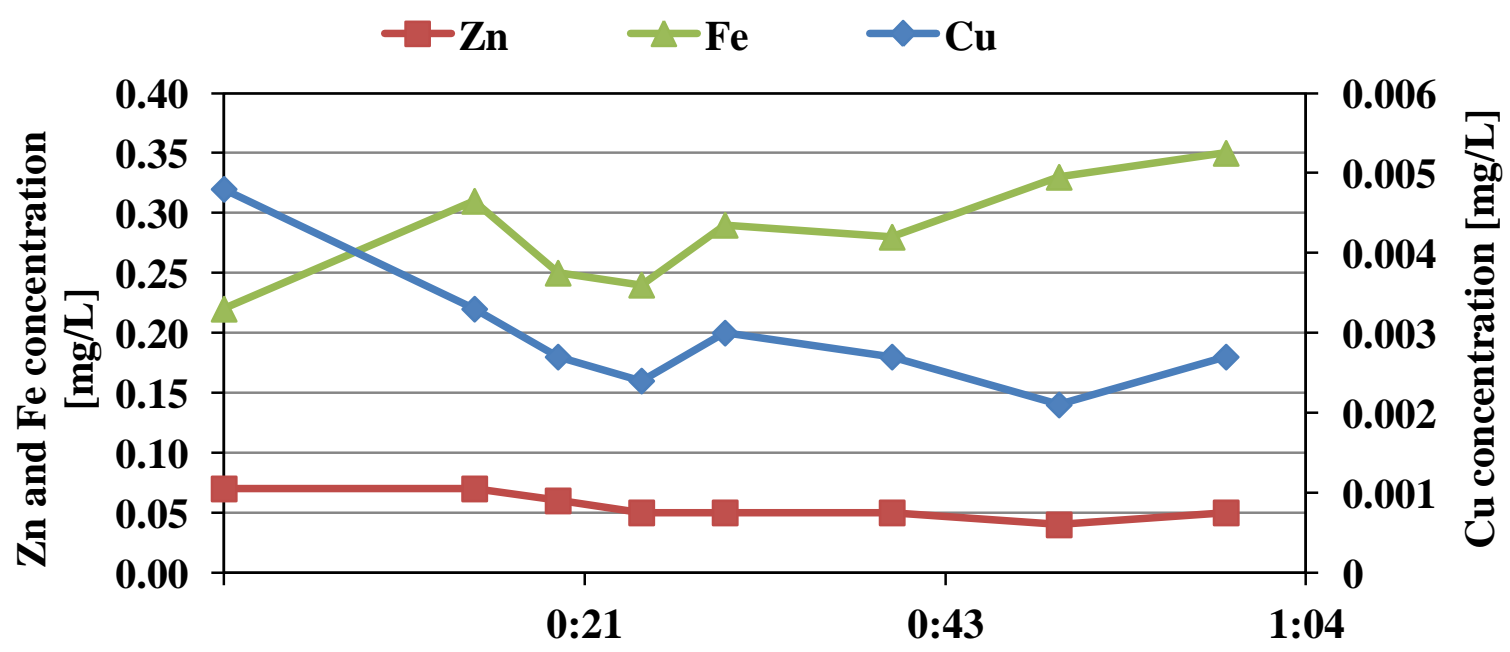

Elapsed time [h]

Figure A1.2 Temporal variation of dissolved $\mathrm{Cu}, \mathrm{Zn}$ and $\mathrm{Fe}$ concentrations for the monitored storm runoff on 29/05/2011, at site 1 of Porirua Stream. 
Table A1.6 Data of the monitored storm runoff on 05/06/2011 at site 1 of Porirua Stream.

Number of antecedent dry days

7

\section{Metal concentration}

[mg/L]

Sampling time

\begin{tabular}{cccc} 
& $\mathbf{C u}$ & $\mathbf{Z n}$ & $\mathbf{F e}$ \\
\hline 8:45 am & 0.0048 & 0.05 & 0.41 \\
9:00 am & 0.0030 & 0.05 & 0.34 \\
9:19 am & 0.0030 & 0.08 & 0.28 \\
9:27 am & 0.0027 & 0.04 & 0.43 \\
9:38 am & 0.0027 & 0.04 & 0.52 \\
$10: 38 \mathrm{am}$ & 0.0024 & 0.03 & 0.36 \\
$11: 27 \mathrm{am}$ & 0.0030 & 0.04 & 0.42 \\
$12: 31 \mathrm{pm}$ & 0.0033 & 0.05 & 0.30 \\
\hline
\end{tabular}

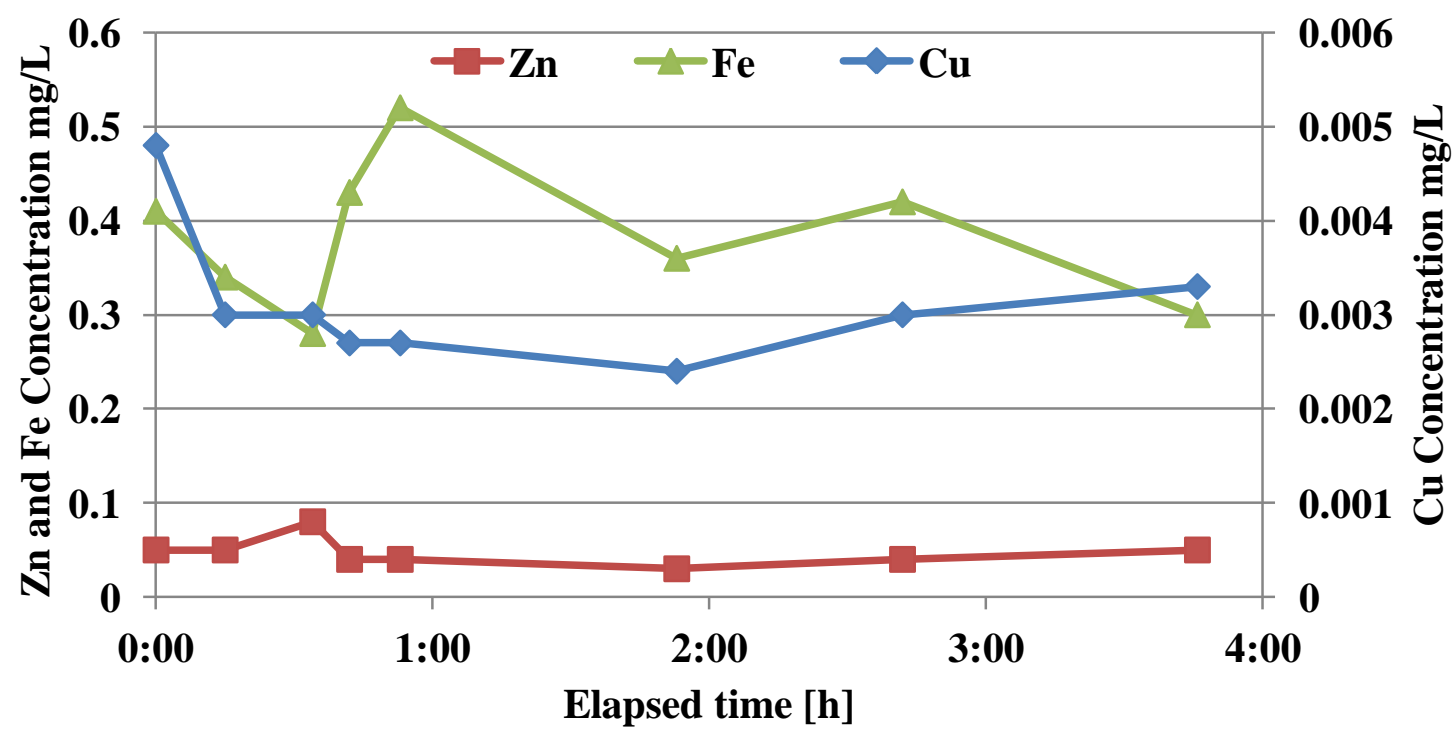

Figure A1.3 Temporal variation of dissolved $\mathrm{Cu}, \mathrm{Zn}$ and $\mathrm{Fe}$ for the monitored storm runoff on 05/06/2011 at site 1 of Porirua Stream. 


\section{A1.2 Sites 2 and 3 Data}

Table A1.7 Dissolved Cu concentrations (mg/L) at sites 2 and site 3 of Porirua Stream.

\begin{tabular}{|c|c|c|c|c|}
\hline Sample type & Base flow site 2 & Storm runoff site 2 & Base flow site 3 & Storm runoff site 3 \\
\hline Number of samples & 20 & 10 & 22 & 8 \\
\hline \multirow{2}{*}{$\begin{array}{l}\text { Number of omitted samples } \\
\text { Minimum [mg/L] }\end{array}$} & 9 & 3 & 10 & 3 \\
\hline & 0.0012 & 0.0018 & 0.0012 & 0.0021 \\
\hline $25^{\text {th }}$ percentile $[\mathrm{mg} / \mathrm{L}]$ & 0.0015 & 0.0022 & 0.0015 & 0.0024 \\
\hline Median $[\mathrm{mg} / \mathrm{L}]$ & 0.0027 & 0.0027 & 0.0018 & 0.0051 \\
\hline $75^{\text {th }}$ percentile $[\mathrm{mg} / \mathrm{L}]$ & 0.0039 & 0.0063 & 0.0026 & 0.0078 \\
\hline Maximum [mg/L] & 0.0063 & 0.0076 & 0.0048 & 0.0088 \\
\hline Average $[\mathrm{mg} / \mathrm{L}]$ & 0.0029 & 0.0042 & 0.0023 & 0.0052 \\
\hline Std. dev. [mg/L] & 0.0017 & 0.0025 & 0.0012 & 0.0030 \\
\hline *Factor of exceeding the HMTV & 1.5 & 1.5 & Not exceeding & 2.8 \\
\hline *Factor of exceeding the CMC & Not applicable & Not exceeding & Not applicable & Not exceeding \\
\hline
\end{tabular}

*Based on the median values. 
Table A1.8 Dissolved Zn concentrations (mg/L) at sites 2 and site 3 of Porirua Stream.

\begin{tabular}{|c|c|c|c|c|}
\hline Sample type & Base flow site 2 & Storm runoff site 2 & Base flow site 3 & Storm runoff site 3 \\
\hline Number of omitted samples & 1 & 0 & 1 & 0 \\
\hline $25^{\text {th }}$ percentile $[\mathrm{mg} / \mathrm{L}]$ & 0.010 & 0.050 & 0.012 & 0.027 \\
\hline Median $[\mathrm{mg} / \mathrm{L}]$ & 0.040 & 0.065 & 0.040 & 0.060 \\
\hline Maximum [mg/L] & 0.150 & 0.250 & 0.110 & 0.120 \\
\hline Average $[\mathrm{mg} / \mathrm{L}]$ & 0.043 & 0.091 & 0.040 & 0.059 \\
\hline Std. dev. $[\mathrm{mg} / \mathrm{L}]$ & 0.037 & 0.0820 & 0.029 & 0.035 \\
\hline *Factor of exceeding the HMTV & 3.8 & 6.2 & 3.8 & 5.7 \\
\hline
\end{tabular}


Table A1.9 Dissolved Fe concentrations (mg/L) at sites 2 and site 3 of Porirua Stream.

\begin{tabular}{|c|c|c|c|c|}
\hline Sample type & Base flow site 2 & Storm runoff site 2 & Base flow site 3 & Storm runoff site 3 \\
\hline Number of samples & 20 & 10 & 22 & 8 \\
\hline Minimum [mg/L] & 0.07 & 0.19 & 0.05 & 0.10 \\
\hline $25^{\text {th }}$ percentile $[\mathrm{mg} / \mathrm{L}]$ & 0.14 & 0.21 & 0.11 & 0.17 \\
\hline Median [mg/L] & 0.17 & 0.25 & 0.16 & 0.52 \\
\hline $75^{\text {th }}$ percentile $[\mathrm{mg} / \mathrm{L}]$ & 0.29 & 0.61 & 0.22 & 0.75 \\
\hline Maximum [mg/L] & 0.89 & 1.57 & 0.64 & 2.26 \\
\hline Average $[\mathrm{mg} / \mathrm{L}]$ & 0.24 & 0.50 & 0.19 & 0.66 \\
\hline Std. dev. $[\mathrm{mg} / \mathrm{L}]$ & 0.2 & 0.4 & 0.1 & 0.7 \\
\hline *Factor of exceeding the CTV & Not exceeding & Not exceeding & Not exceeding & 1.7 \\
\hline
\end{tabular}

*Based on the median values. 


\section{A1.3 Site 4 Data}

Table A1.10 Dissolved Cu concentrations (mg/L) at site 4 of Porirua Stream.

\begin{tabular}{|c|c|c|c|c|}
\hline Sample type & Base flow & First flush & Composite & Storm runoff \\
\hline Number of samples & 22 & 1 & 1 & 10 \\
\hline Number of omitted samples & 8 & 0 & 0 & 4 \\
\hline $25^{\text {th }}$ percentile $[\mathrm{mg} / \mathrm{L}]$ & 0.0021 & NA & NA & 0.0025 \\
\hline Median [mg/L] & 0.0021 & NA & NA & 0.0037 \\
\hline Maximum [mg/L] & 0.0063 & NA & NA & 0.016 \\
\hline Average $[\mathrm{mg} / \mathrm{L}]$ & 0.0026 & 0.0031 & 0.0015 & 0.0055 \\
\hline Std. dev. $[\mathrm{mg} / \mathrm{L}]$ & 0.0013 & NA & NA & 0.0054 \\
\hline
\end{tabular}


Table A1.11 Dissolved Zn concentrations (mg/L) obtained at site 4 of Porirua Stream.

\begin{tabular}{|c|c|c|c|c|}
\hline Sample type & Base flow & First flush & Composite & Storm runoff \\
\hline Number of samples & 22 & 1 & 1 & 10 \\
\hline Number of omitted samples & 1 & 0 & 0 & 0 \\
\hline Minimum [mg/L] & 0.010 & NA & NA & 0.020 \\
\hline $25^{\text {th }}$ percentile $[\mathrm{mg} / \mathrm{L}]$ & 0.016 & NA & NA & 0.034 \\
\hline Median [mg/L] & 0.040 & NA & NA & 0.050 \\
\hline $75^{\text {th }}$ percentile $[\mathrm{mg} / \mathrm{L}]$ & 0.070 & NA & NA & 0.075 \\
\hline Maximum [mg/L] & 0.090 & NA & NA & 0.150 \\
\hline Average $[\mathrm{mg} / \mathrm{L}]$ & 0.044 & 0.016 & 0.018 & 0.060 \\
\hline Std. dev. $[\mathrm{mg} / \mathrm{L}]$ & 0.027 & NA & NA & 0.041 \\
\hline *Factor of exceeding the HMTV & 4 & 1.7 & 1.8 & 5 \\
\hline *Factor of exceeding the CMC & Not applicable & Not exceeding & Not exceeding & Not exceeding \\
\hline
\end{tabular}

*Based on the median values. NA: not applicable. In the table, first flush and composite samples are single data points and the values are placed in average cells. 
Table A1.12 Dissolved Fe concentrations (mg/L) obtained at site 4 of Porirua Stream.

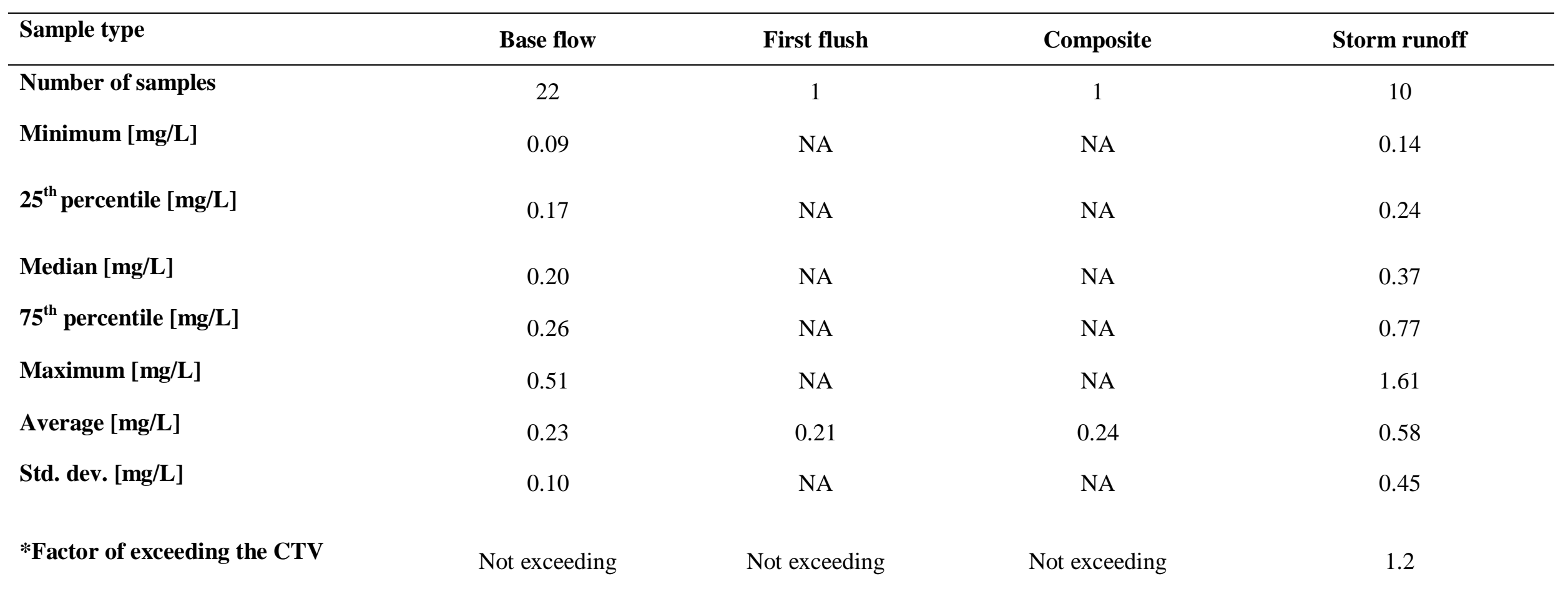

*Based on the median values. NA: not applicable. In the table, first flush and composite samples are single data points and the values are placed in average cells 
Table A1.13 Data of the monitored storm on 23/06/2011 at site 4 of Porirua Stream.

\begin{tabular}{|c|c|c|c|}
\hline $\begin{array}{l}\text { Number of antecedent } \\
\text { dry days }\end{array}$ & \multicolumn{3}{|c|}{4} \\
\hline \multirow[t]{2}{*}{ Sampling time } & \multicolumn{3}{|c|}{ Metal concentration $(\mathrm{mg} / \mathrm{L})$} \\
\hline & $\mathbf{C u}$ & $\mathbf{Z n}$ & $\mathbf{F e}$ \\
\hline $9: 38 \mathrm{am}$ & 0.0045 & 0.0192 & 0.23 \\
\hline $10: 00 \mathrm{am}$ & 0.0018 & 0.014 & 0.19 \\
\hline $10: 30 \mathrm{am}$ & 0.0018 & 0.0177 & 0.23 \\
\hline 11:00 am & 0.0012 & 0.016 & 0.18 \\
\hline $12: 00 \mathrm{pm}$ & 0.0015 & 0.0195 & 0.31 \\
\hline
\end{tabular}

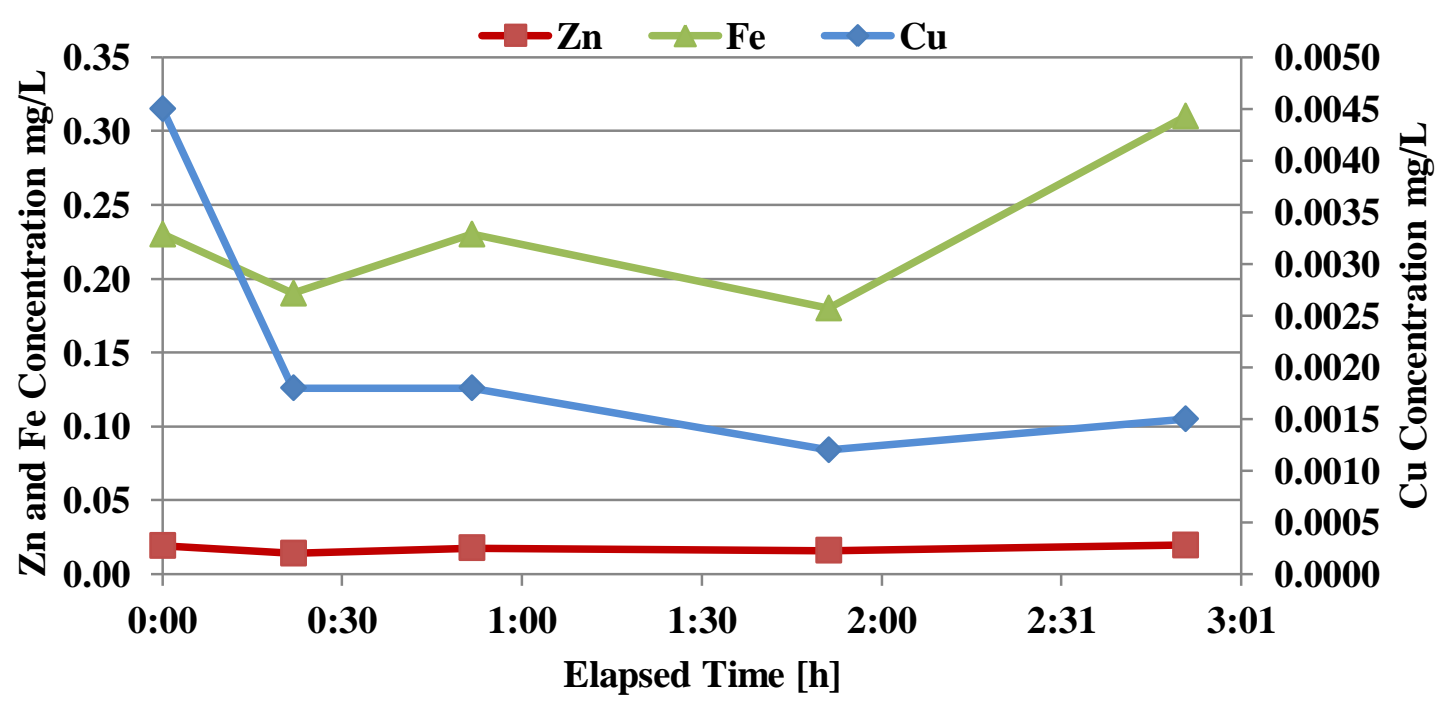

Figure A1.4 Temporal variation of dissolved $\mathrm{Cu}, \mathrm{Zn}$ and $\mathrm{Fe}$ in the monitored storm runoff on 23/06/2011 at site 4 of Porirua Stream. 


\section{A1.4 Site 5 Data}

Table A1.14 Dissolved Cu concentrations (mg/L) at site 5 of Kenepuru Stream.

\begin{tabular}{|c|c|c|c|c|}
\hline Sample type & Base flow & First flush & Composite & Storm runoff \\
\hline Number of samples & 21 & 1 & 1 & 10 \\
\hline Number of omitted samples & 10 & 0 & 0 & 5 \\
\hline Minimum [mg/L] & 0.0012 & NA & NA & 0.0021 \\
\hline $25^{\text {th }}$ percentile $[\mathrm{mg} / \mathrm{L}]$ & 0.0016 & NA & NA & 0.0030 \\
\hline Median [mg/L] & 0.0021 & NA & NA & 0.0033 \\
\hline $75^{\text {th }}$ percentile $[\mathrm{mg} / \mathrm{L}]$ & 0.0036 & NA & NA & 0.0048 \\
\hline Maximum [mg/L] & 0.0060 & NA & NA & 0.020 \\
\hline Average $[\mathrm{mg} / \mathrm{L}]$ & 0.0027 & 0.0017 & 0.0019 & 0.0066 \\
\hline Std. dev. $[\mathrm{mg} / \mathrm{L}]$ & 0.0017 & NA & NA & 0.0075 \\
\hline *Factor of exceeding the ANZECC (2000) TV & 1.5 & 1.2 & 1.3 & 2.4 \\
\hline *Factor of exceeding the CMC & Not applicable & Not exceeding & Not exceeding & Not exceeding \\
\hline
\end{tabular}

*Based on the median values. NA: not applicable. In the table, one base flow data point was below, and assumed to be, the enhanced detection limit. Note that first flush and composite samples are single data points and the values are placed in average cells. 
Table A1.15 Dissolved Zn concentrations (mg/L) at site 5 of Kenpuru Stream.

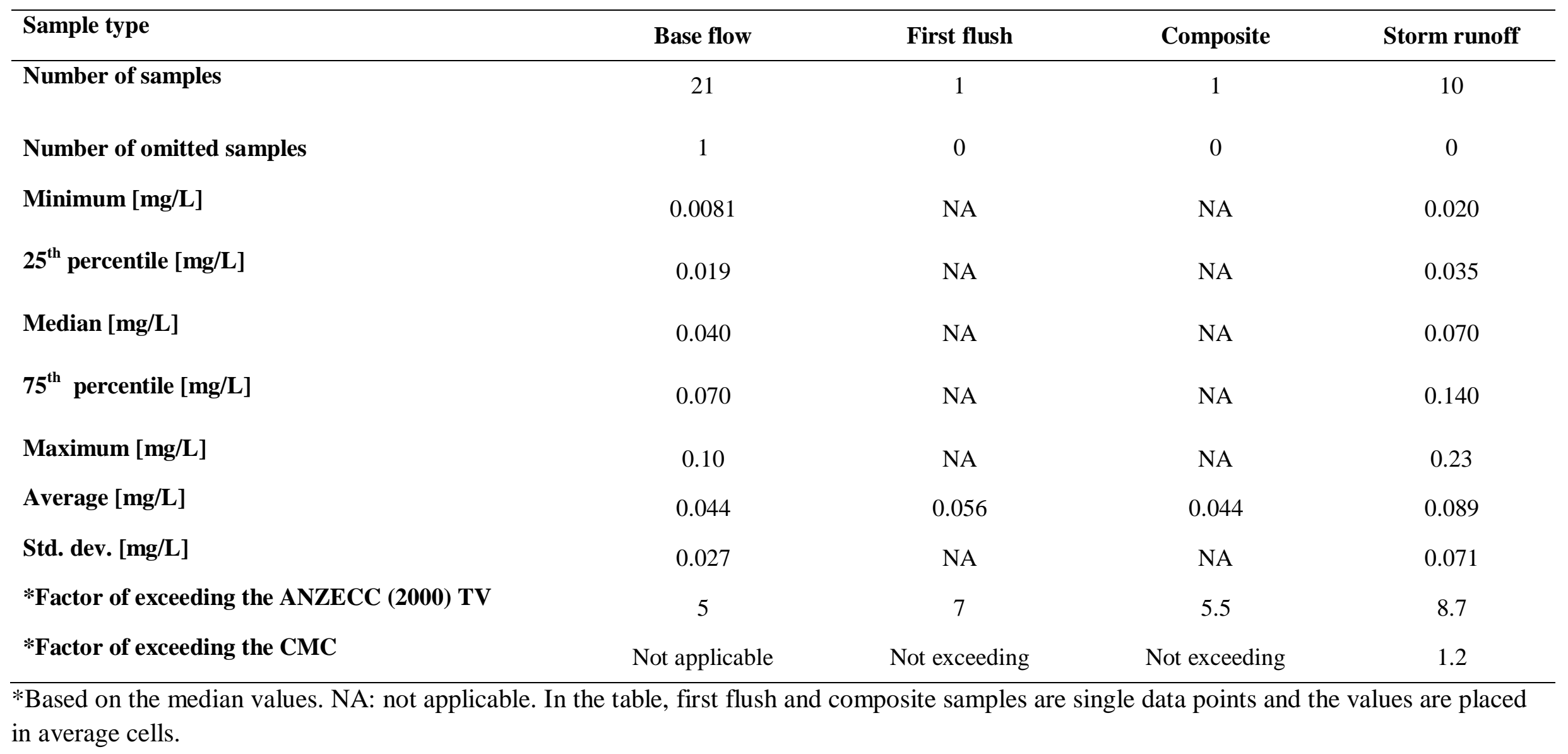


Table A1.16 Dissolved Fe concentrations (mg/L) at site 5 of Kenepuru Stream.

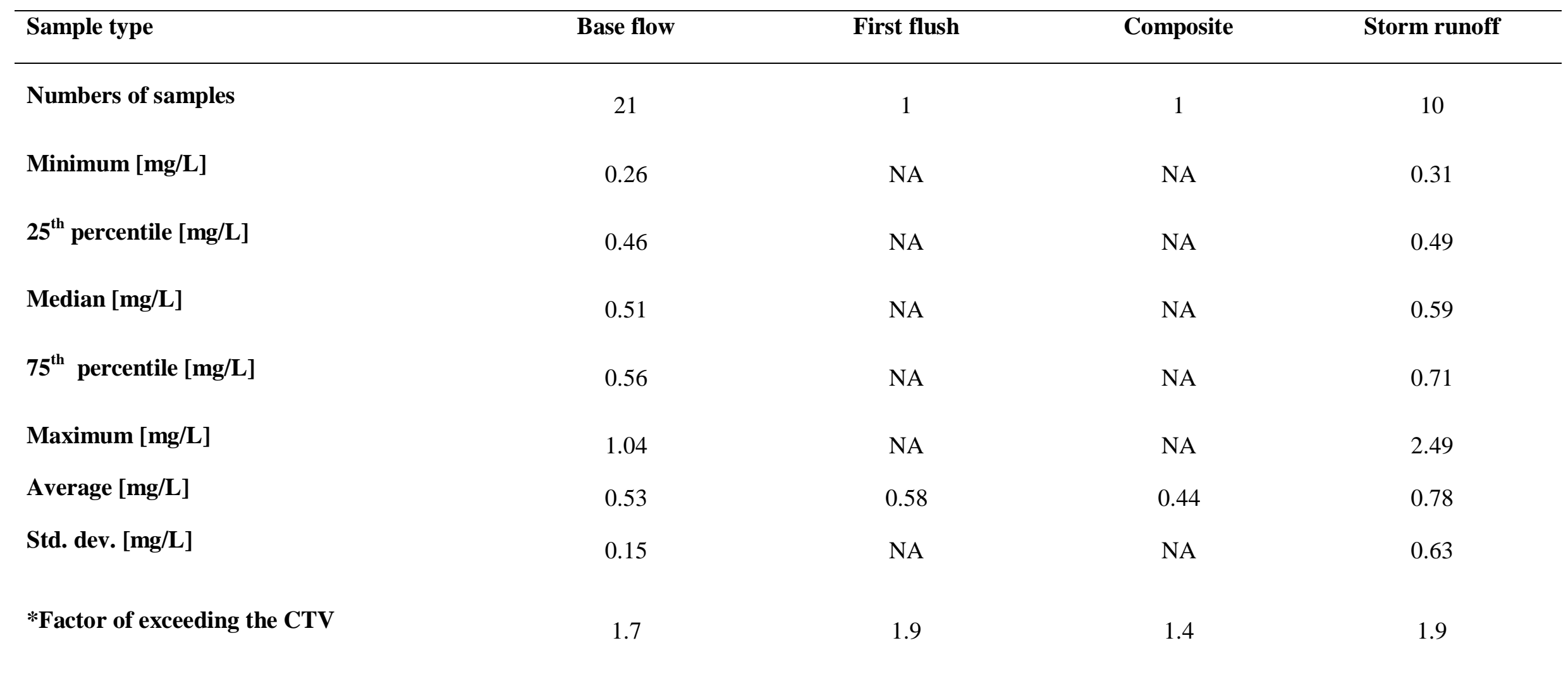

\footnotetext{
*Based on the median values. NA: not applicable. In the table, first flush and composite samples are a single data points each and were placed in average cells.
} 
Table A1.17 Data for the monitored storm on 18/06/2011 at site 5 of Kenepuru Stream.

\begin{tabular}{|c|c|c|c|}
\hline $\begin{array}{c}\text { Number of antecedent } \\
\text { dry days }\end{array}$ & & 6 & \\
\hline \multirow[t]{2}{*}{ Sampling time } & \multicolumn{3}{|c|}{$\begin{array}{c}\text { Metal concentration } \\
{[\mathrm{mg} / \mathrm{L}]}\end{array}$} \\
\hline & $\mathbf{C u}$ & Zn & $\mathbf{F e}$ \\
\hline $8: 00 \mathrm{am}$ & 0.0024 & 0.09 & 0.7 \\
\hline 8:05 am & 0.0018 & 0.06 & 0.63 \\
\hline $8: 10 \mathrm{am}$ & 0.0015 & 0.05 & 0.49 \\
\hline $8: 15$ am & 0.0012 & 0.04 & 0.61 \\
\hline $8: 25 \mathrm{am}$ & 0.0015 & 0.04 & 0.52 \\
\hline $8: 35 \mathrm{am}$ & 0.0015 & 0.04 & 0.5 \\
\hline $8: 45 \mathrm{am}$ & 0.0015 & 0.04 & 0.48 \\
\hline 9:00 am & 0.0018 & 0.05 & 0.47 \\
\hline $9: 35 \mathrm{am}$ & 0.0021 & 0.04 & 0.39 \\
\hline $10: 35 \mathrm{am}$ & 0.0021 & 0.04 & 0.37 \\
\hline $11: 35 \mathrm{am}$ & 0.0021 & 0.06 & 0.44 \\
\hline $12: 35 \mathrm{pm}$ & 0.0021 & 0.04 & 0.42 \\
\hline
\end{tabular}

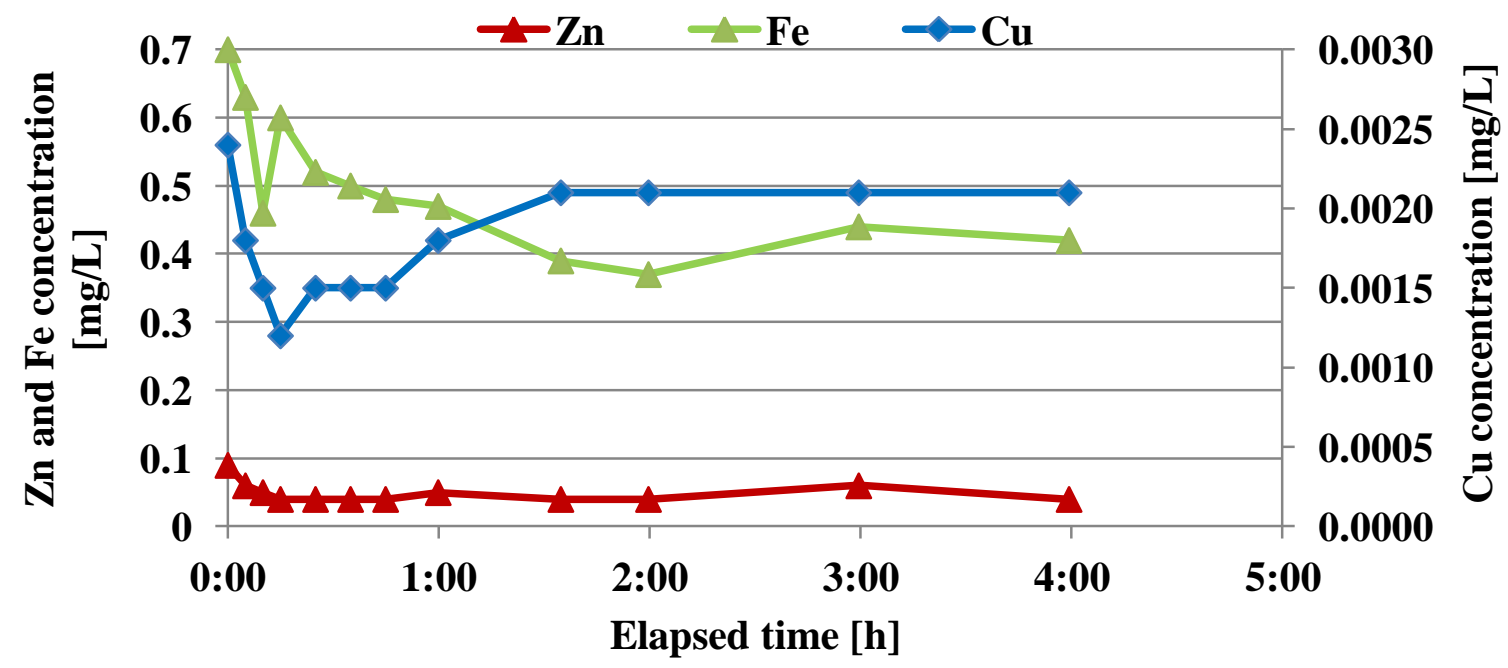

Figure A1.5 Temporal variation of dissolved $\mathrm{Cu}, \mathrm{Zn}$ and $\mathrm{Fe}$ concentrations for the monitored storm runoff on 18/06/2011 at site 5 of Kenepuru Stream. 


\section{A1.5 Sites 6 and 7 Data}

Table A1.18 Dissolved Cu concentrations (mg/L) at site 6 and 7 of Takapu Stream.

\begin{tabular}{|c|c|c|c|c|}
\hline Sample type & Base flow site 6 & Storm runoff site 6 & Base flow site 7 & Storm runoff site 7 \\
\hline Number of samples & 20 & 9 & 20 & 9 \\
\hline Number of omitted samples & 6 & 3 & 6 & 3 \\
\hline Minimum [mg/L] & 0.0012 & 0.0012 & 0.0012 & 0.0012 \\
\hline $25^{\text {th }}$ percentile $[\mathrm{mg} / \mathrm{L}]$ & 0.0012 & 0.0014 & 0.0012 & 0.0018 \\
\hline Median [mg/L] & 0.0012 & 0.0024 & 0.0012 & 0.0022 \\
\hline $75^{\text {th }}$ percentile $[\mathrm{mg} / \mathrm{L}]$ & 0.0015 & 0.0043 & 0.0020 & 0.0031 \\
\hline Maximum [mg/L] & 0.0027 & 0.0064 & 0.0036 & 0.014 \\
\hline Average $[\mathrm{mg} / \mathrm{L}]$ & 0.0015 & 0.0030 & 0.0017 & 0.0041 \\
\hline Std. dev. $[\mathrm{mg} / \mathrm{L}]$ & 0.000539 & 0.0021 & 0.00087 & 0.0049 \\
\hline *Factor of exceeding the ANZECC (2000) TV & Not exceeding & 1.7 & Not exceeding & 1.6 \\
\hline *Factor of exceeding The CMC & Not applicable & Not exceeding & Not applicable & Not exceeding \\
\hline
\end{tabular}

*Based on the median values. In the table, the concentration of dissolved $\mathrm{Cu}$ in 5 and 7 base flow samples and 1 storm runoff sample for site 6 and site 7 respectively were below, and assumed to be, the enhanced detection limit of $\mathrm{Cu}$. 
Table A1.19 Dissolved Zn concentrations (mg/L) at site 6 and 7 of Takapu Stream.

\begin{tabular}{|c|c|c|c|c|}
\hline Sample type & Base flow site 6 & Storm runoff site 6 & Base flow site 7 & Storm runoff site 7 \\
\hline Number of samples & 20 & 9 & 20 & 9 \\
\hline Number of omitted samples & 1 & 0 & 1 & 0 \\
\hline Minimum [mg/L] & 0.0048 & 0.010 & 0.0075 & 0.010 \\
\hline $25^{\text {th }}$ percentile $[\mathrm{mg} / \mathrm{L}]$ & 0.0067 & 0.027 & 0.0089 & 0.027 \\
\hline Median [mg/L] & 0.013 & 0.055 & 0.030 & 0.050 \\
\hline $75^{\text {th }}$ percentile $[\mathrm{mg} / \mathrm{L}]$ & 0.050 & 0.10 & 0.055 & 0.072 \\
\hline Maximum [mg/L] & 0.08 & 0.23 & 0.09 & 0.29 \\
\hline Average $[\mathrm{mg} / \mathrm{L}]$ & 0.027 & 0.085 & 0.035 & 0.075 \\
\hline Std. dev. $[\mathrm{mg} / \mathrm{L}]$ & 0.024 & 0.086 & 0.028 & 0.090 \\
\hline *Factor of exceeding the ANZECC (2000) TV & 1.6 & 6.9 & 3.7 & 6.2 \\
\hline *Factor of exceeding the CMC & Not applicable & Not exceeding & Not applicable & Not exceeding \\
\hline
\end{tabular}

*Based on the median values. 
Table A1.20 Dissolved Fe concentrations (mg/L) at site 6 and 7 of Takapu Stream.

\begin{tabular}{|c|c|c|c|c|}
\hline Sample type & Base flow site6 & Storm runoff site 6 & Base flow site 7 & Storm runoff site 7 \\
\hline Number of samples & 20 & 9 & 20 & 9 \\
\hline Minimum [mg/L] & 0.045 & 0.08 & 0.045 & 0.045 \\
\hline $25^{\text {th }}$ percentile $[\mathrm{mg} / \mathrm{L}]$ & 0.045 & 0.11 & 0.085 & 0.15 \\
\hline Median [mg/L] & 0.08 & 0.2 & 0.13 & 0.23 \\
\hline $75^{\text {th }}$ percentile $[\mathrm{mg} / \mathrm{L}]$ & 0.095 & 0.42 & 0.19 & 0.31 \\
\hline Maximum [mg/L] & 0.21 & 0.75 & 0.31 & 2.53 \\
\hline Average $[\mathrm{mg} / \mathrm{L}]$ & 0.084 & 0.29 & 0.14 & 0.49 \\
\hline Std. dev. [mg/L] & 0.046 & 0.23 & 0.077 & 0.83 \\
\hline *Factor of exceeding the CTV & Not exceeding & Not exceeding & Not exceeding & Not exceeding \\
\hline
\end{tabular}

*Based on the median value. In the table, the concentration of dissolved Fe in 7 base flow samples for site 6 and 3 base flow and 1 storm runoff samples for site 7 were below, and assumed to be, the detection limit of Fe. 


\section{A1.6 Sites 8 and 10 Data}

Table A1.21 Dissolved Cu concentrations (mg/L) at site 8 of Karori Stream.

\begin{tabular}{|c|c|c|c|c|}
\hline Sample type & Base flow & First flush & Composite & Storm runoff \\
\hline Number of samples & 17 & 2 & 2 & 5 \\
\hline Number of omitted samples & 2 & 0 & 0 & 0 \\
\hline $25^{\text {th }}$ percentile $[\mathrm{mg} / \mathrm{L}]$ & 0.0015 & NA & NA & 0.0064 \\
\hline Median [mg/L] & 0.0021 & NA & NA & 0.0087 \\
\hline Maximum [mg/L] & 0.022 & NA & NA & 0.03 \\
\hline Average $[\mathrm{mg} / \mathrm{L}]$ & 0.0042 & 0.0046 & 0.0031 & 0.014 \\
\hline Std. dev. $[\mathrm{mg} / \mathrm{L}]$ & 0.0052 & 0.0011 & 0.00024 & 0.010 \\
\hline *Factor of exceeding the HMTV & 1.3 & 3 & 2 & 5.7 \\
\hline
\end{tabular}

*Based on the median values. NA: not applicable. In the table, first flush and composite samples are single data points and the values were averaged and compared against the HMTV and CMC. 
Table A1.22 Dissolved Cu concentrations (mg/L) at site 10 of Karori Stream.

\begin{tabular}{lcc}
\hline Sample type & Base flow & Storm runoff \\
\hline Number of samples & 17 & 5 \\
Number of omitted samples & 2 & 0 \\
Minimum [mg/L] & 0.0012 & 0.0012 \\
$\mathbf{2 5}^{\text {th }}$ percentile [mg/L] & 0.0012 & 0.0032 \\
Median [mg/L] & 0.0021 & 0.0036 \\
$\mathbf{7 5}^{\text {th }}$ percentile [mg/L] & 0.0030 & 0.0060 \\
Maximum [mg/L] & 0.0081 & 0.011 \\
Average [mg/L] & 0.0023 & 0.0050 \\
Std. dev. [mg/L] & 0.0019 & 0.0038 \\
*Factor of exceeding the HMTV & 1.4 & 2.4 \\
*Factor of exceeding the CMC & Not applicable & Not exceeding
\end{tabular}

*Based on the median values. In the table, 5 base flow and 1 storm runoff samples were below, and assumed to be, the enhanced detection limit of $\mathrm{Cu}$. 
Table A1.23 Dissolved Zn concentrations (mg/L) at site 8 of Karori Stream.

\begin{tabular}{|c|c|c|c|c|}
\hline Sample type & Base flow & First flush & Composite & Storm runoff \\
\hline Number of samples & 17 & 2 & 2 & 5 \\
\hline Number of omitted samples & 1 & 0 & 0 & 0 \\
\hline Minimum [mg/L] & 0.017 & NA & NA & 0.032 \\
\hline $25^{\text {th }}$ percentile $[\mathrm{mg} / \mathrm{L}]$ & 0.020 & NA & NA & 0.060 \\
\hline Median [mg/L] & 0.0315 & NA & NA & 0.077 \\
\hline $75^{\text {th }}$ percentile $[\mathrm{mg} / \mathrm{L}]$ & 0.05 & NA & NA & 0.10 \\
\hline Maximum [mg/L] & 0.07 & NA & NA & 0.120 \\
\hline Average $[\mathrm{mg} / \mathrm{L}]$ & 0.037 & 0.081 & 0.065 & 0.077 \\
\hline Std. dev. $[\mathrm{mg} / \mathrm{L}]$ & 0.018 & 0.016 & 0.0070 & 0.034 \\
\hline *Factor of exceeding the HMTV & 3.6 & 9.4 & 7.5 & 8.9 \\
\hline *Factor of exceeding the CMC & Not applicable & 1.4 & 1.1 & 1.3 \\
\hline
\end{tabular}

*Based on the median values. NA: not applicable. In the table, first flush and composite samples are two data points and the values are averaged and compared against the HMTV and CMC. 
Table A1.24 Dissolved Zn concentrations (mg/L) at site 10 of Karori Stream.

\begin{tabular}{lcc}
\hline Sample type & Base flow & Storm runoff \\
\hline Number of samples & 17 & 5 \\
Number of omitted samples & 1 & 0 \\
Minimum [mg/L] & 0.007 & 0.007 \\
$\mathbf{2 5}^{\text {th }}$ percentile [mg/L] & 0.023 & 0.019 \\
Median [mg/L] & 0.030 & 0.050 \\
$\mathbf{7 5}^{\text {th }}$ percentile [mg/L] & 0.050 & 0.090 \\
Maximum [mg/L] & 0.060 & 0.11 \\
Average [mg/L] & 0.032 & 0.055 \\
Std. dev. [mg/L] & 0.015 & 0.044 \\
*Factor of exceeding the HMTV & 3.5 & 5.8 \\
*Factor of exceeding the CMC & Not applicable & Not exceeding \\
\hline
\end{tabular}

*Based on the median values. 
Table A1.25 Dissolved Fe concentrations (mg/L) at site 8 of Karori Stream.

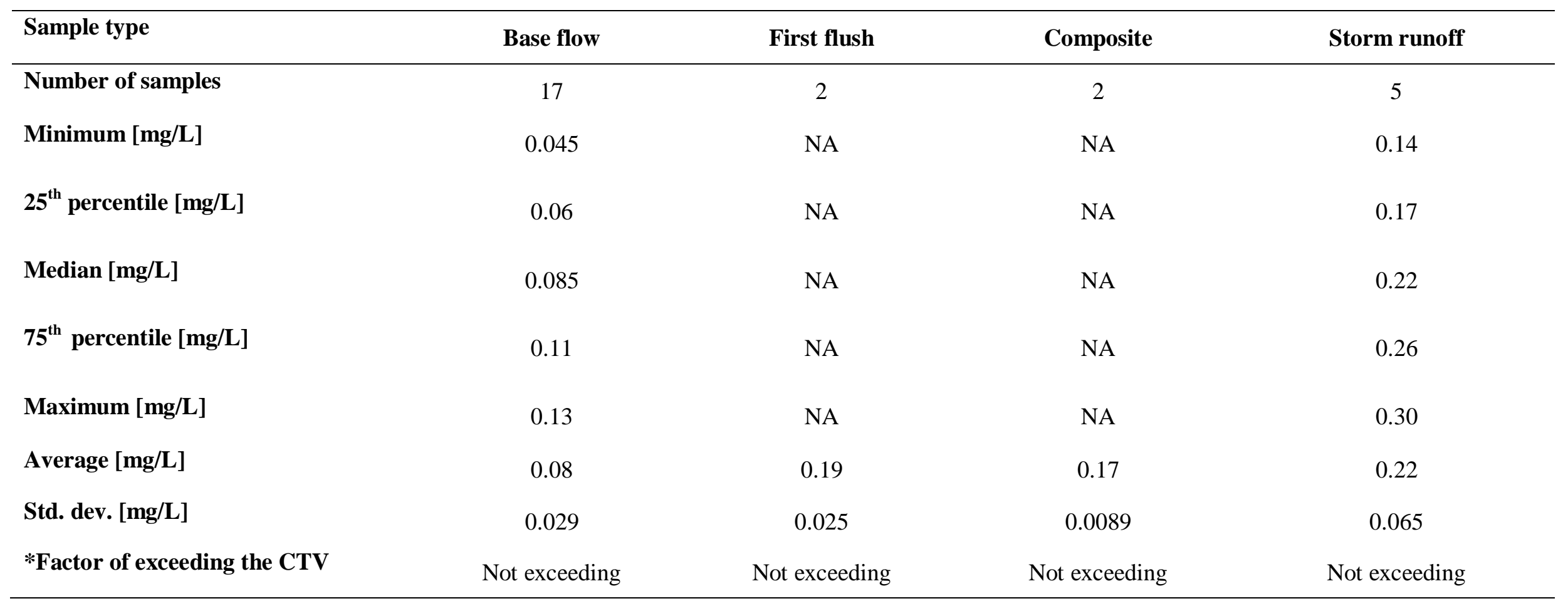

*Based on the median values. NA: not applicable. In the table, first flush and composite samples are two data points and are averaged and compared against the CTV. Note that the concentration of dissolved Fe in 2 base flow samples were below, and assumed to be the detection limit of $\mathrm{Fe}$. 
Table A1.26 Dissolved Fe concentrations (mg/L) at site 10 of Karori Stream.

\begin{tabular}{lcc}
\hline Sample type & Base flow & Storm runoff \\
\hline Number of samples & 17 & 5 \\
Minimum [mg/L] & 0.045 & 0.09 \\
$\mathbf{2 5}^{\text {th }}$ percentile [mg/L] & 0.045 & 0.11 \\
Median [mg/L] & 0.090 & 0.23 \\
$\mathbf{7 5}^{\text {th }}$ percentile [mg/L] & 0.13 & 0.30 \\
Maximum [mg/L] & 0.16 & 0.31 \\
Average [mg/L] & 0.09 & 0.2 \\
Std. dev. [mg/L] & 0.043 & 0.10 \\
*Factor of exceeding the CTV. & Not exceeding & Not exceeding
\end{tabular}

*Based on the median values. In the table, the concentration of dissolved Fe in 6 base flow samples was below, and assumed to be the detection limit of $\mathrm{Fe}$. 
Table A1.27 Data of the monitored storm on 25/04/2011 at site 8 of Karori Stream.

Number of antecedent dry days

\begin{tabular}{lccc}
\hline & \multicolumn{3}{c}{$\begin{array}{c}\text { Metal concentration } \\
\text { [mg/L] }\end{array}$} \\
\cline { 2 - 4 } Sampling time & Cu & Zn & Fe \\
\hline 8:26 am & 0.0030 & 0.09 & 0.22 \\
$8: 28 \mathrm{am}$ & 0.0045 & 0.09 & 0.14 \\
$8: 35 \mathrm{am}$ & 0.0030 & 0.09 & 0.22 \\
$8: 47 \mathrm{am}$ & 0.0048 & 0.10 & 0.25 \\
$8: 56 \mathrm{am}$ & 0.0033 & 0.06 & 0.18 \\
\hline
\end{tabular}

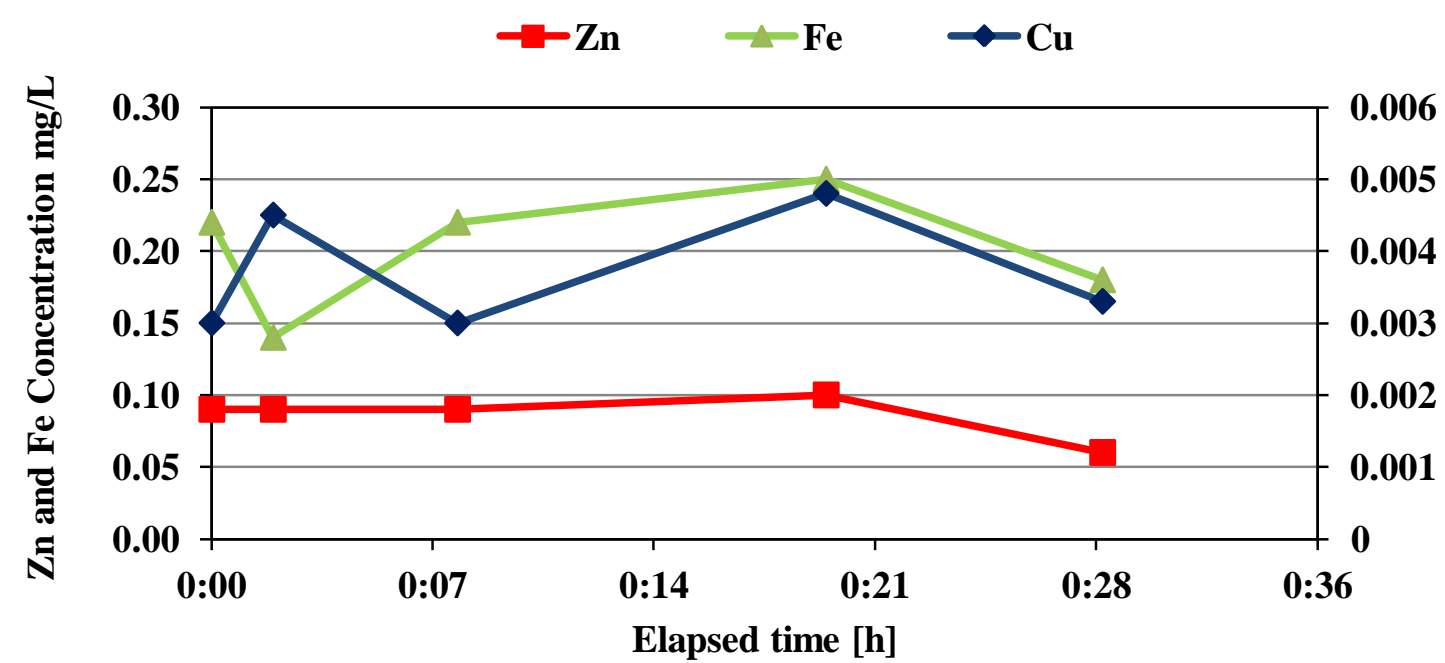

Figure A1.6 Temporal variation of dissolved $\mathrm{Cu}, \mathrm{Zn}$ and $\mathrm{Fe}$ concentrations for the monitored storm runoff on 25/04/2011 at site 8 of Karori Stream. 
Table A1.28 Data of the monitored storm on 23/07/2011 at site 8 of Karori Stream.

\begin{tabular}{|c|c|c|c|}
\hline $\begin{array}{l}\text { Number of antecedent } \\
\text { dry days }\end{array}$ & & $\mathbf{0}$ & \\
\hline Sampling time & & $\begin{array}{l}\text { centr: } \\
; / L]\end{array}$ & \\
\hline & $\mathbf{C u}$ & $\mathbf{Z n}$ & Fe \\
\hline 7:00 a.m. & 0.0063 & 0.09 & 0.22 \\
\hline 7:05 a.m. & 0.006 & 0.07 & 0.15 \\
\hline 7:10 a.m. & 0.0054 & 0.06 & 0.19 \\
\hline 7:15 a.m. & 0.0045 & 0.06 & 0.16 \\
\hline 7:20 a.m. & 0.0048 & 0.07 & 0.14 \\
\hline 7:30 a.m. & 0.0063 & 0.08 & 0.15 \\
\hline 7:40 a.m. & 0.0042 & 0.08 & 0.14 \\
\hline 8:30 a.m. & 0.003 & 0.05 & 0.19 \\
\hline 9:10 a.m. & 0.0033 & 0.09 & 0.16 \\
\hline 10:00 a.m. & 0.0021 & 0.06 & 0.18 \\
\hline 11:00 a.m. & 0.0024 & 0.05 & 0.16 \\
\hline 12:00 p.m. & $<0.0012 *$ & 0.06 & 0.18 \\
\hline 2:00 p.m. & $<0.0012 *$ & 0.09 & 0.18 \\
\hline
\end{tabular}

* The concentrations are assumed to be the enhanced detection limit of $\mathrm{Cu}$. 


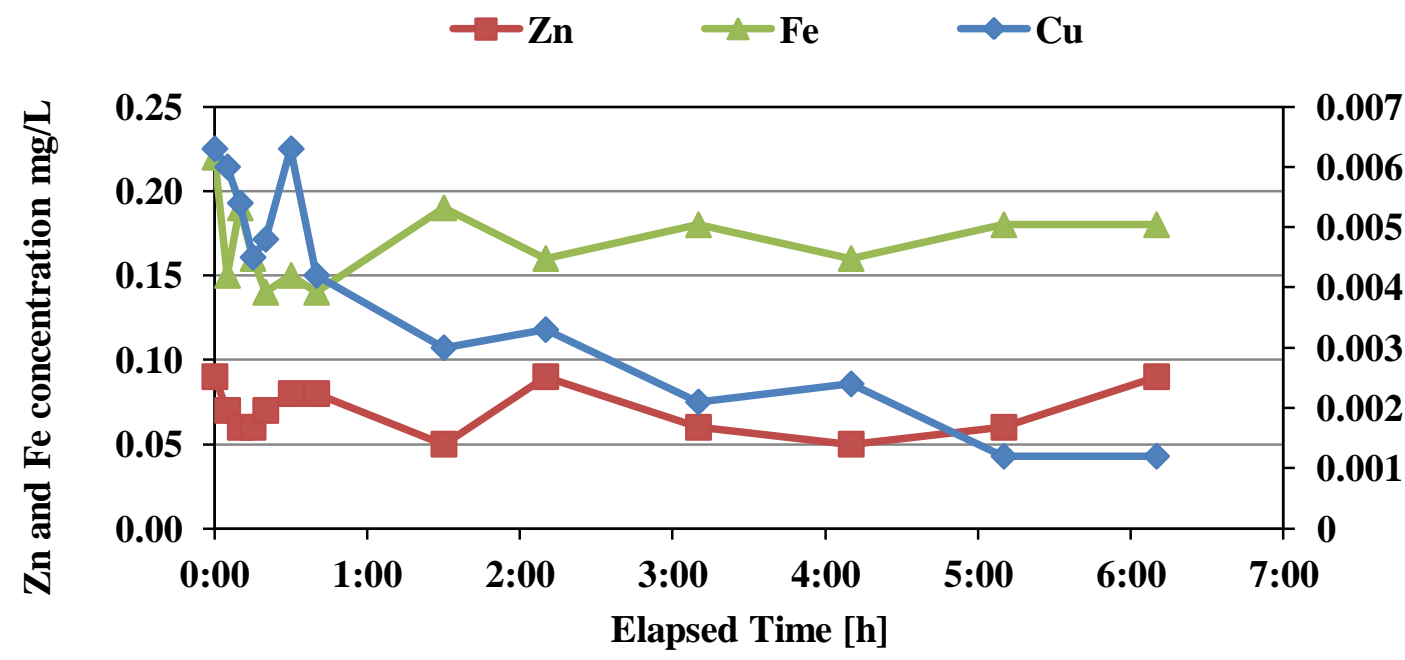

Figure A1.7 Temporal variation of dissolved $\mathrm{Cu}, \mathrm{Zn}$ and $\mathrm{Fe}$ concentrations for the monitored storm runoff on 23/07/2011 at site 8 of Karori Stream.
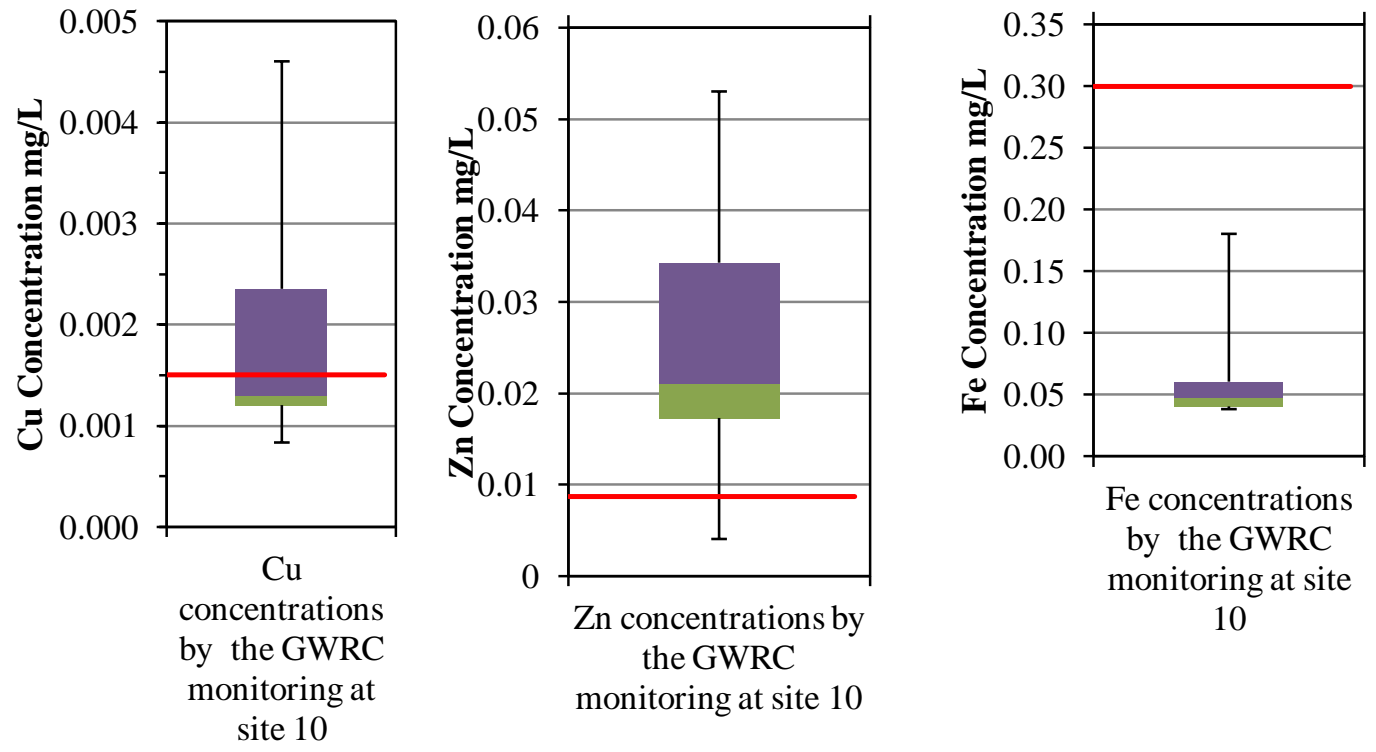

Figure A1.8 HMTVs for $\mathrm{Cu}$ and $\mathrm{Zn}, \mathrm{CTV}$ for Fe (horizontal red lines) and statistical parameters of dissolved $\mathrm{Cu}, \mathrm{Zn}$, and $\mathrm{Fe}$, left to right, unpublished data of monitoring program conducted between January/2008 to Jun/2009 by the GWRC14 at site 9, Karori Stream at Makara Peak, Mountain Bike Park [34].

${ }^{14}$ Note that the data was provided in tables. 


\section{A1.7 Site 9 Data}

Table A1.29 Dissolved Cu concentrations (mg/L) for site 9, a tributary of Karori Stream.

\begin{tabular}{|c|c|c|c|c|}
\hline Sample type & Base flow & First flush & Composite & Storm runoff \\
\hline Number of samples & 17 & 1 & 1 & 5 \\
\hline Number of omitted samples & 2 & 0 & 0 & 0 \\
\hline Minimum [mg/L] & 0.0012 & NA & NA & 0.0015 \\
\hline $25^{\text {th }}$ percentile $[\mathrm{mg} / \mathrm{L}]$ & 0.0012 & NA & NA & 0.0024 \\
\hline Median [mg/L] & 0.0019 & NA & NA & 0.0042 \\
\hline $75^{\text {th }}$ percentile $[\mathrm{mg} / \mathrm{L}]$ & 0.0033 & NA & NA & 0.0048 \\
\hline Maximum [mg/L] & 0.0057 & 0.0013 & 0.0012 & 0.0072 \\
\hline Average $[\mathrm{mg} / \mathrm{L}]$ & 0.0024 & NA & NA & 0.0040 \\
\hline Std. dev. $[\mathrm{mg} / \mathrm{L}]$ & 0.0013 & NA & NA & 0.0022 \\
\hline *Factor of exceeding the HMTV & 1.3 & 0 & 0 & 2.7 \\
\hline *Factor of exceeding the CMC & Not applicable & Not exceeding & Not exceeding & Not exceeding \\
\hline
\end{tabular}

*Based on the median values. NA: not applicable. In the table, the concentrations of dissolved $\mathrm{Cu}$ in 5 base flow samples were below, and assumed to be, the enhanced detection limit. Note that first flush and composite samples are single data points and they are placed in average cells. 
Table A1.30 Dissolved Zn concentrations (mg/L) for site 9, a tributary of Karori Stream.

\begin{tabular}{|c|c|c|c|c|}
\hline Sample type & Base flow & First flush & Composite & Storm runoff \\
\hline Number of samples & 17 & 1 & 1 & 5 \\
\hline Minimum [mg/L] & 0.010 & NA & NA & 0.014 \\
\hline $25^{\text {th }}$ percentile $[\mathrm{mg} / \mathrm{L}]$ & 0.014 & NA & NA & 0.024 \\
\hline Median [mg/L] & 0.023 & NA & NA & 0.030 \\
\hline $75^{\text {th }}$ percentile $[\mathrm{mg} / \mathrm{L}]$ & 0.030 & NA & NA & 0.080 \\
\hline Maximum [mg/L] & 0.050 & NA & NA & 0.090 \\
\hline Average $[\mathrm{mg} / \mathrm{L}]$ & 0.025 & 0.045 & 0.029 & 0.048 \\
\hline Std. dev. $[\mathrm{mg} / \mathrm{L}]$ & 0.013 & NA & NA & 0.035 \\
\hline *Factor of exceeding the HMTV & 2.6 & 5.1 & 3.3 & 3.4 \\
\hline *Factor of exceeding the CMC & Not applicable & Not exceeding & Not exceeding & Not exceeding \\
\hline
\end{tabular}

*Based on the median values. NA: not applicable. In the table, first flush and composite samples are single data points and the values are placed in average cells. 
Table A1.31 Dissolved Fe concentration (mg/L) for site 9, a tributary of Karori Stream.

\begin{tabular}{|c|c|c|c|c|}
\hline Sample type & Base flow & First flush & Composite & Storm runoff \\
\hline Minimum [mg/L] & 0.045 & NA & NA & 0.23 \\
\hline $25^{\text {th }}$ percentile $[\mathrm{mg} / \mathrm{L}]$ & 0.13 & NA & NA & 0.33 \\
\hline Median [mg/L] & 0.19 & NA & NA & 0.35 \\
\hline Maximum [mg/L] & 0.37 & NA & NA & 0.4 \\
\hline Average $[\mathrm{mg} / \mathrm{L}]$ & 0.17 & 0.21 & 0.27 & 0.33 \\
\hline Std. dev. [mg/L] & 0.076 & NA & NA & 0.064 \\
\hline
\end{tabular}

*Based on the median values. NA: not applicable. In the table, one base flow sample was below, and assumed to be, the detection limit. Note that, first flush and composite samples are single data points and the values are placed on average cells. 
Table A1.32 Data of the monitored storm runoff event on 23/07/2011 at site 9.

\begin{tabular}{lccc}
\hline $\begin{array}{l}\text { Number of } \\
\text { antecedent dry days }\end{array}$ & \multicolumn{3}{c}{$\mathbf{1 0}$} \\
\hline & \multicolumn{3}{c}{ Metal concentration } \\
Sampling time & $\mathbf{C u}$ & $\mathbf{Z n}$ \\
\hline 7:00 a.m. & 0.00145 & 0.048 & 0.24 \\
7:05 a.m. & $<0.0012^{*}$ & 0.045 & 0.2 \\
7:15 a.m. & $0.0012^{*}$ & 0.044 & 0.2 \\
7:30 a.m. & $<0.0012^{*}$ & 0.047 & 0.21 \\
7:40 a.m. & 0.0012 & 0.046 & 0.22 \\
8:30 a.m. & $<0.0012^{*}$ & 0.012 & 0.22 \\
9:10 a.m. & 0.0012 & 0.032 & 0.35 \\
10:00 a.m. & $<0.0012^{*}$ & 0.028 & 0.28 \\
11:00 a.m. & $<0.0012^{*}$ & 0.032 & 0.33 \\
12:00 a.m. & $<0.0012^{*}$ & 0.01 & 0.34 \\
2:00 a.m. & $<0.0012^{*}$ & 0.03 & 0.27 \\
\hline
\end{tabular}

* The concentrations are assumed to be the enhanced detection limit of $\mathrm{Cu}$.

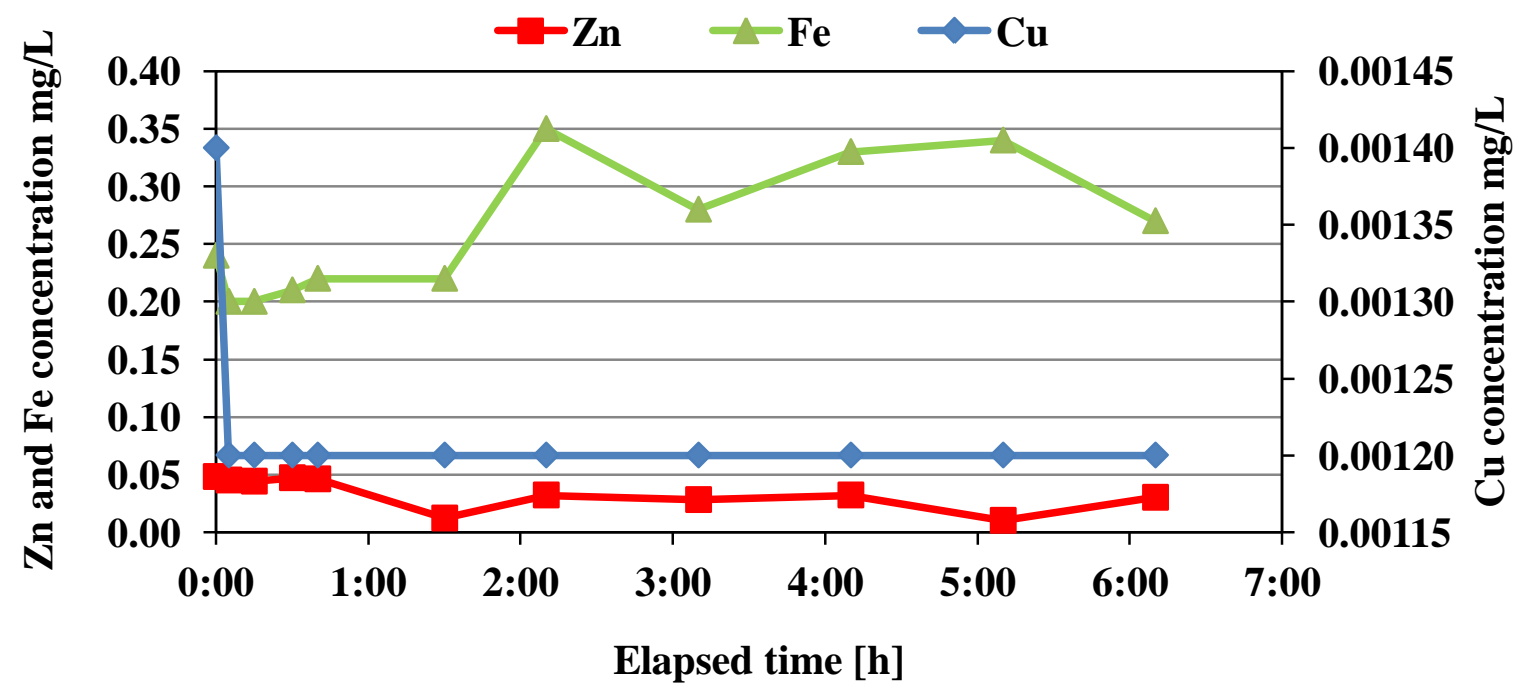

Figure A1.9 Temporal variation of dissolved $\mathrm{Cu}, \mathrm{Zn}$ and $\mathrm{Fe}$ for the monitored storm runoff on 23/07/2011 at site 9, a tributary of Karori Stream. 


\section{A1.2 Sites 11, 12 and 13 Data}

Table A1.33 Dissolved Cu concentrations (mg/L) at site 11, site12 of Makara Stream, and site 13 of Ohariu Stream.

\begin{tabular}{|c|c|c|c|c|c|c|}
\hline Sample type & $\begin{array}{c}\text { Site } 11 \\
\text { base flow }\end{array}$ & $\begin{array}{c}\text { Site 11 } \\
\text { storm runoff }\end{array}$ & $\begin{array}{c}\text { Site } 12 \\
\text { base flow }\end{array}$ & $\begin{array}{c}\text { Site } 12 \\
\text { storm runoff }\end{array}$ & $\begin{array}{c}\text { Site } 13 \\
\text { base flow }\end{array}$ & $\begin{array}{c}\text { Site } 13 \\
\text { storm runoff }\end{array}$ \\
\hline Number of samples & 17 & 5 & 17 & 5 & 17 & 5 \\
\hline Number of omitted samples & 3 & 0 & 3 & 0 & 3 & 0 \\
\hline Minimum [mg/L] & 0.0012 & 0.0012 & 0.0012 & 0.0012 & 0.0012 & 0.0012 \\
\hline $75^{\text {th }}$ percentile $[\mathrm{mg} / \mathrm{L}]$ & 0.0021 & 0.0051 & 0.0030 & 0.0044 & 0.0024 & 0.0044 \\
\hline Maximum [mg/L] & 0.0039 & 0.0056 & 0.0039 & 0.0051 & 0.0039 & 0.0090 \\
\hline Average $[\mathrm{mg} / \mathrm{L}]$ & 0.0017 & 0.0032 & 0.0021 & 0.0029 & 0.0019 & 0.0042 \\
\hline *Factor of exceeding the CMC & Not applicable & Not exceeding & Not applicable & Not exceeding & Not applicable & Not exceeding \\
\hline
\end{tabular}

*Based on the median values. In the table, the concentration of dissolved $\mathrm{Cu}$ in $8,4,6$ base flow samples and 2, 1, 1 storm runoff samples were below, and assumed to be, the enhanced detection limit of $\mathrm{Cu}$ for sites 11, 1213 respectively. 
Table A1.34 Dissolved Zn concentrations (mg/L) at site 11 and site12 of Makara Stream and site 13 of Ohariu Stream.

\begin{tabular}{|c|c|c|c|c|c|c|}
\hline Sample type & $\begin{array}{c}\text { Site } 11 \\
\text { base flow }\end{array}$ & $\begin{array}{c}\text { Site } 11 \\
\text { storm runoff }\end{array}$ & $\begin{array}{c}\text { Site } 12 \\
\text { base flow }\end{array}$ & $\begin{array}{c}\text { Site } 12 \\
\text { storm runoff }\end{array}$ & $\begin{array}{c}\text { Site } 13 \\
\text { base flow }\end{array}$ & $\begin{array}{c}\text { Site } 13 \\
\text { storm runoff }\end{array}$ \\
\hline Number of samples & 17 & 5 & 17 & 5 & 17 & 5 \\
\hline $\begin{array}{l}\text { Number of omitted } \\
\text { samples }\end{array}$ & 2 & 0 & 2 & 0 & 2 & 0 \\
\hline Minimum [mg/L] & 0.0051 & 0.01 & 0.0012 & 0.009 & 0.006 & 0.01 \\
\hline $25^{\text {th }}$ percentile $[\mathrm{mg} / \mathrm{L}]$ & 0.0087 & 0.02 & 0.0075 & 0.01 & 0.008 & 0.01 \\
\hline Median $[\mathrm{mg} / \mathrm{L}]$ & 0.01 & 0.027 & 0.01 & 0.01 & 0.01 & 0.014 \\
\hline $75^{\text {th }}$ percentile $[\mathrm{mg} / \mathrm{L}]$ & 0.02 & 0.06 & 0.025 & 0.07 & 0.013 & 0.05 \\
\hline Maximum [mg/L] & 0.05 & 0.08 & 0.05 & 0.07 & 0.05 & 0.06 \\
\hline Average $[\mathrm{mg} / \mathrm{L}]$ & 0.016 & 0.039 & 0.016 & 0.034 & 0.013 & 0.029 \\
\hline Std. dev. $[\mathrm{mg} / \mathrm{L}\}$ & 0.014 & 0.029 & 0.014 & 0.033 & 0.011 & 0.024 \\
\hline $\begin{array}{l}\text { *Factor of exceeding the } \\
\text { HMTV }\end{array}$ & 0 & 2.7 & Not exceeding & Not exceeding & Not exceeding & 1.4 \\
\hline $\begin{array}{l}\text { *Factor of exceeding the } \\
\text { CMC }\end{array}$ & Not applicable & Not exceeding & Not applicable & Not exceeding & Not applicable & Not exceeding \\
\hline
\end{tabular}

*Based on the median values. 
Table A1.35 Dissolved Fe concentrations (mg/L) for site 11 and site 12 of Makara Stream and site 13 of Ohariu Stream.

\begin{tabular}{|c|c|c|c|c|c|c|}
\hline Sample type & $\begin{array}{c}\text { Site } 11 \\
\text { Base flow }\end{array}$ & $\begin{array}{c}\text { Site } 11 \\
\text { Storm runoff }\end{array}$ & $\begin{array}{c}\text { Site } 12 \\
\text { Base flow }\end{array}$ & $\begin{array}{c}\text { Site } 12 \\
\text { Storm runoff }\end{array}$ & $\begin{array}{c}\text { Site 13 } \\
\text { Base flow }\end{array}$ & $\begin{array}{c}\text { Site } 13 \\
\text { Storm runoff }\end{array}$ \\
\hline Number of samples & 17 & 5 & 17 & 5 & 17 & 5 \\
\hline $25^{\text {th }}$ percentile $[\mathrm{mg} / \mathrm{L}]$ & 0.07 & 0.28 & 0.11 & 0.18 & 0.09 & 0.56 \\
\hline Median [mg/L] & 0.12 & 0.36 & 0.15 & 0.43 & 0.15 & 0.61 \\
\hline Maximum [mg/L] & 0.23 & 0.9 & 0.22 & 0.73 & 0.29 & 1.8 \\
\hline Average $[\mathrm{mg} / \mathrm{L}]$ & 0.12 & 0.53 & 0.14 & 0.42 & 0.15 & 0.77 \\
\hline Std. dev. $[\mathrm{mg} / \mathrm{L}]$ & 0.05 & 0.34 & 0.05 & 0.250 & 0.07 & 0.6 \\
\hline
\end{tabular}




\section{Atmospheric rainfall samples}

Table A1.36 Dissolved $\mathrm{Cu}, \mathrm{Zn}$ and Fe concentrations (mg/L) in the atmospheric rainfall samples collected at VUW.

\begin{tabular}{lccc}
\hline Metals & $\mathbf{C u}$ & $\mathbf{Z n}$ & $\mathbf{F e}$ \\
\hline Number of samples & 24 & 24 & 24 \\
Number of omitted sample & $17^{*}$ & 0 & $6^{* *}$ \\
Minimum [mg/L] & 0.0018 & 0.007 & 0.05 \\
$\mathbf{2 5}^{\text {th }}$ percentile [mg/L] & 0.0021 & 0.040 & 0.06 \\
Median [mg/L] & 0.0057 & 0.090 & 0.10 \\
$\mathbf{7 5}^{\text {th }}$ percentile [mg/L] & 0.0081 & 0.135 & 0.16 \\
Maximum [mg/L] & 0.010 & 0.23 & 0.44 \\
Average [mg/L] & 0.0054 & 0.094 & 0.13 \\
Std. dev. [mg/L] & 0.0036 & 0.066 & 0.096
\end{tabular}

*The samples were below the detection limit or the enhanced detection limit.**The samples were below the detection limit of Fe. 


\section{Roof runoff samples}

Table A1.37 Dissolved $\mathrm{Cu}, \mathrm{Zn}$ and Fe concentrations (mg/L) in the galvanised roof runoff samples.

\begin{tabular}{lccc}
\hline Metals & $\mathbf{C u}$ & $\mathbf{Z n}$ & $\mathbf{F e}$ \\
\hline Number of samples & 15 & 15 & 15 \\
Number of omitted samples & $5^{*}$ & 0 & $7^{* *}$ \\
Minimum [mg/L] & 0.0015 & 0.02 & 0.047 \\
$\mathbf{2 5}^{\text {th }}$ percentile [mg/L] & 0.0022 & 0.09 & 0.05 \\
Median [mg/L] & 0.0046 & 0.15 & 0.065 \\
$\mathbf{7 5}^{\text {th }}$ percentile [mg/L] & 0.0054 & 0.70 & 0.12 \\
Maximum [mg/L] & 0.0078 & 1.9 & 0.35 \\
Average [mg/L] & 0.0044 & 0.5 & 0.12 \\
Std. dev. [mg/L] & 0.0021 & 0.62 & 0.11
\end{tabular}

*The samples are below the detection limit or the enhanced detection limit.**The samples are below the detection limit of Fe. 


\section{Paved surface runoff Samples}

Table A1.38 Dissolved $\mathrm{Cu}, \mathrm{Zn}$ and $\mathrm{Fe}$ concentrations (mg/L) in paved surfaces runoff off samples.

\begin{tabular}{lccc}
\hline Metals & $\mathbf{C u}$ & $\mathbf{Z n}$ & $\mathbf{F e}$ \\
\hline $\begin{array}{l}\text { Number of samples } \\
\text { Number of omitted } \\
\text { samples }\end{array}$ & 16 & 16 & 16 \\
Minimum [mg/L] & $5 *$ & 0 & $5 * *$ \\
& 0.0024 & 0.010 & 0.05 \\
$\mathbf{2 5}^{\text {th }}$ percentile [mg/L] & 0.0033 & 0.024 & 0.07 \\
Median [mg/L] & 0.0040 & 0.045 & 0.16 \\
$\begin{array}{l}\text { 75 } \\
\text { th percentile [mg/L] }\end{array}$ & 0.0081 & 0.22 & 0.58 \\
Maximum [mg/L] & 0.040 & 0.93 & 0.74 \\
$\begin{array}{l}\text { Average [mg/L] } \\
\text { Std. dev. [mg/L] }\end{array}$ & 0.0081 & 0.17 & 0.31 \\
\hline The samples are below the detection limit or the enhanced detection limit.**The \\
samples are below the detection limit of Fe.
\end{tabular}

Table A1.39 Data of the monitored street storm runoff at site 1 on 05/06/2011

\begin{tabular}{lccc}
\hline $\begin{array}{l}\text { Number of } \\
\text { antecedent dry } \\
\text { days }\end{array}$ & \multicolumn{3}{c}{ Metal concentration } \\
\hline \multicolumn{3}{l}{ [mg/L] } \\
Sampling time & Cu & Fe \\
\hline 8:50 am & 0.0021 & 0.03 & 0.4 \\
$9: 11 \mathrm{am}$ & 0.0024 & 0.04 & 0.51 \\
$9: 18 \mathrm{am}$ & 0.0024 & 0.06 & 0.39 \\
$9: 30 \mathrm{am}$ & 0.0009 & 0.04 & 0.46 \\
$11: 30 \mathrm{am}$ & 0.0012 & 0.04 & 0.52 \\
$12: 30 \mathrm{pm}$ & 0.0012 & 0.04 & 0.41 \\
\hline
\end{tabular}




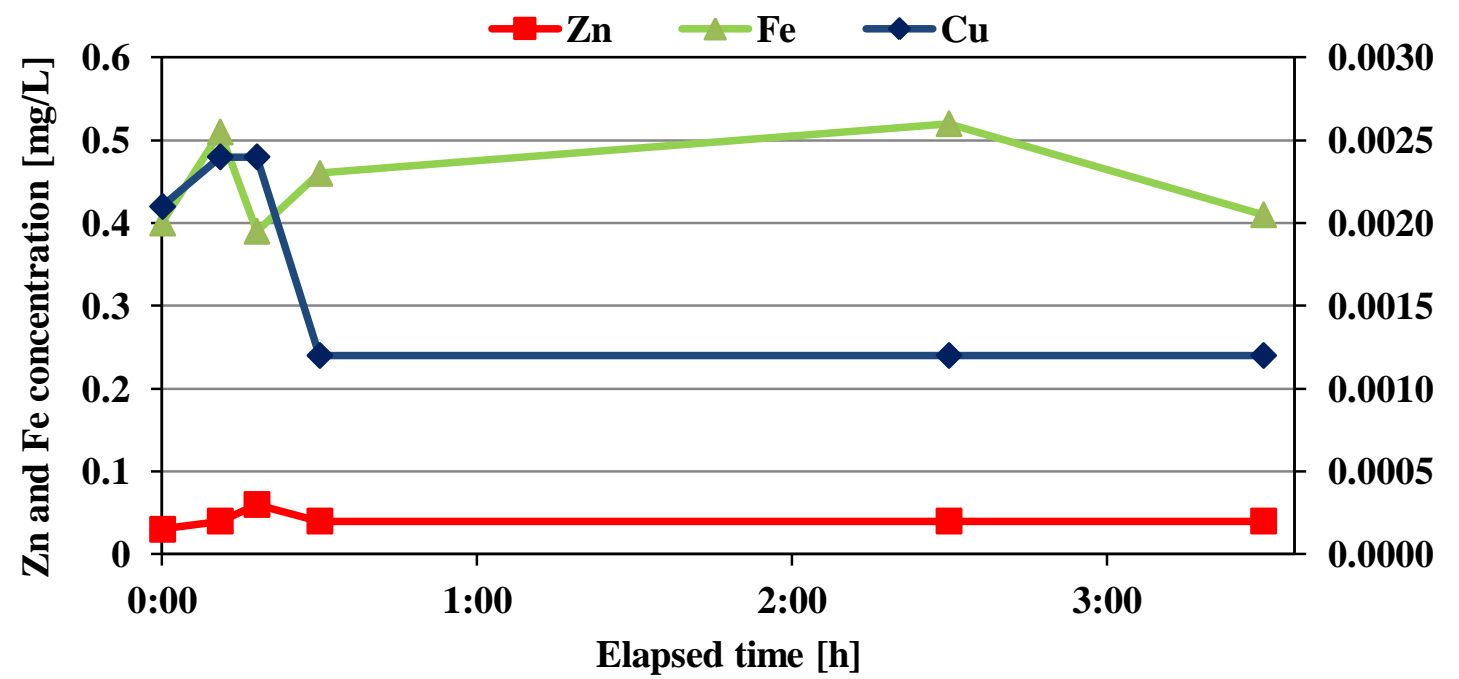

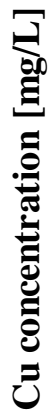

Figure A1.10 Temporal variation of dissolved $\mathrm{Cu}, \mathrm{Zn}$ and $\mathrm{Fe}$ for the monitored street storm runoff at site 1 on 05/06/2011. 


\section{Appendix 2}

\section{Quality assurance}

\section{A) Consistency}

In order to determine the stability of research results, control chats are used (Shewharts charts). A given concentration of the analyte, subjected to quality control, is monitored over time and the mean and standard deviation are calculated. At least 10-15 data points should be used to satisfy the requirements of this type of test [52]. In this work, the variations of dissolved $\mathrm{Cu}, \mathrm{Zn}$ and $\mathrm{Fe}$ concentrations (1.2, 1.2 and 5 $\mathrm{mg} / \mathrm{L}$ respectively) were observed between June-July/2011. The means and standard deviations were calculated. Upper and lower action limits (UAL and LAL) were calculated, mean \pm 3 standard deviation. Figures A.2.1, A.2.2 and A2.3 show that the analysis of dissolved $\mathrm{Cu}, \mathrm{Zn}$ and $\mathrm{Fe}$ was statically consistent.

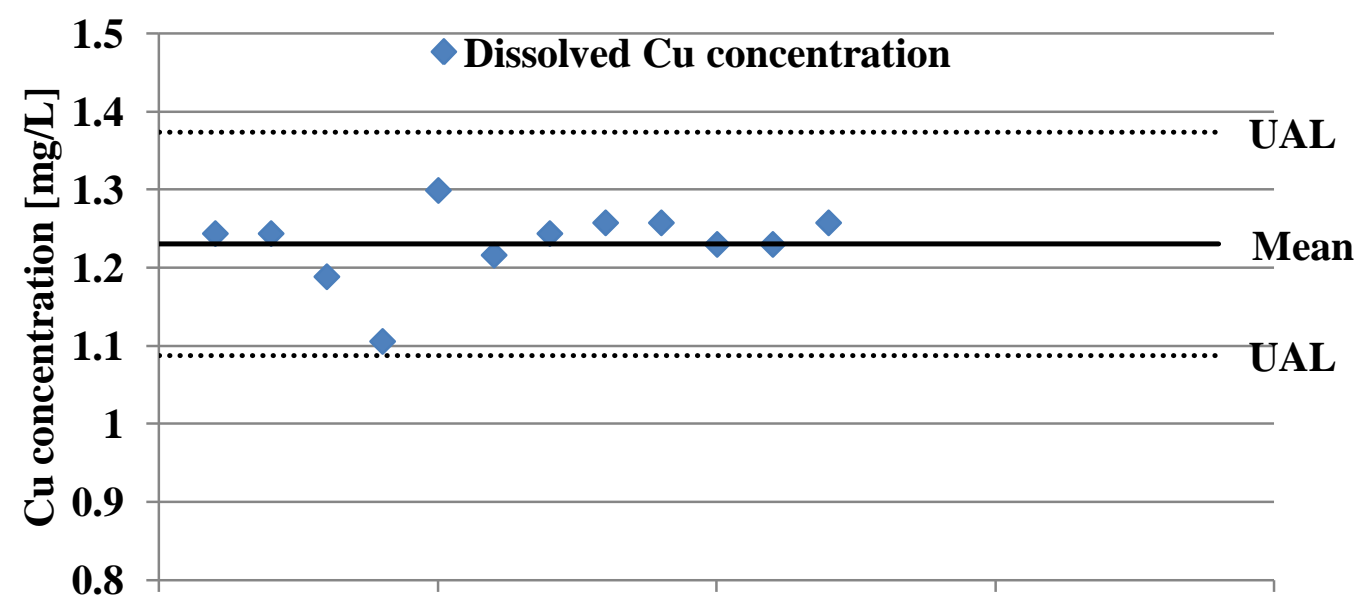

Figure A2.1 Variation of the analysis of dissolved $\mathrm{Cu}(1.2 \mathrm{mg} / \mathrm{L})$ between JuneJuly/2011 


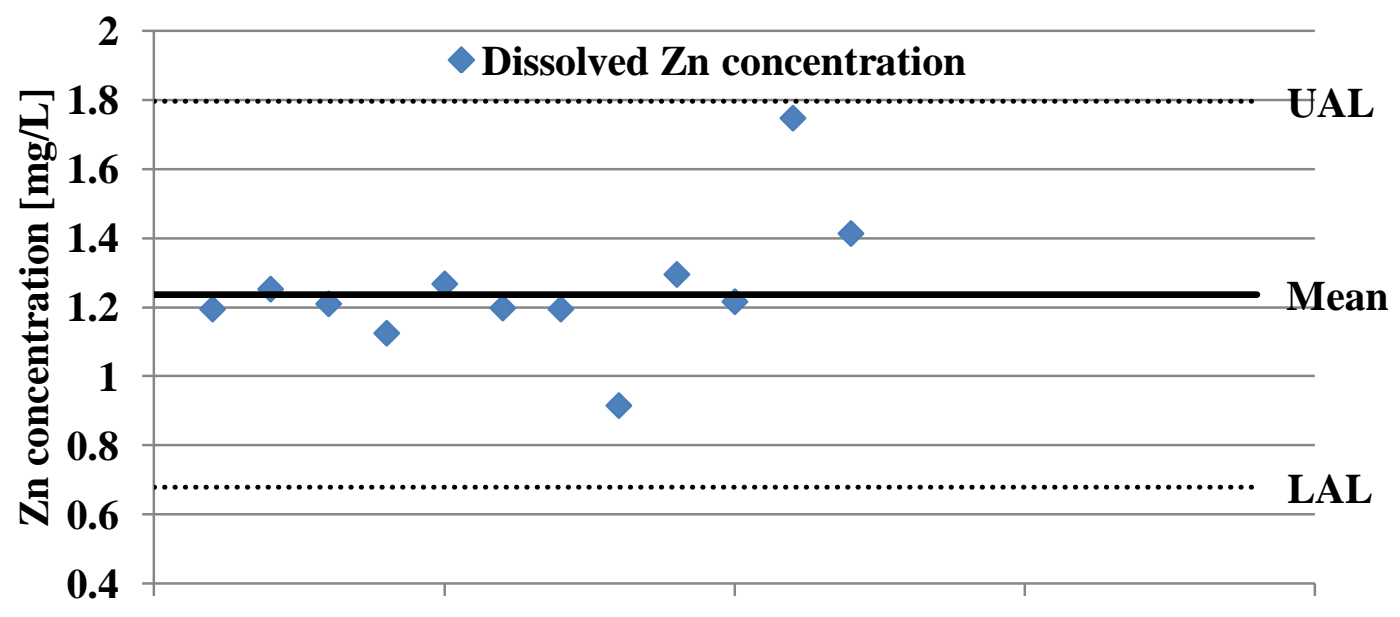

Figure A2.2 Variation of the analysis of dissolved Zn (1.2 mg/L) between JuneJuly/2011.

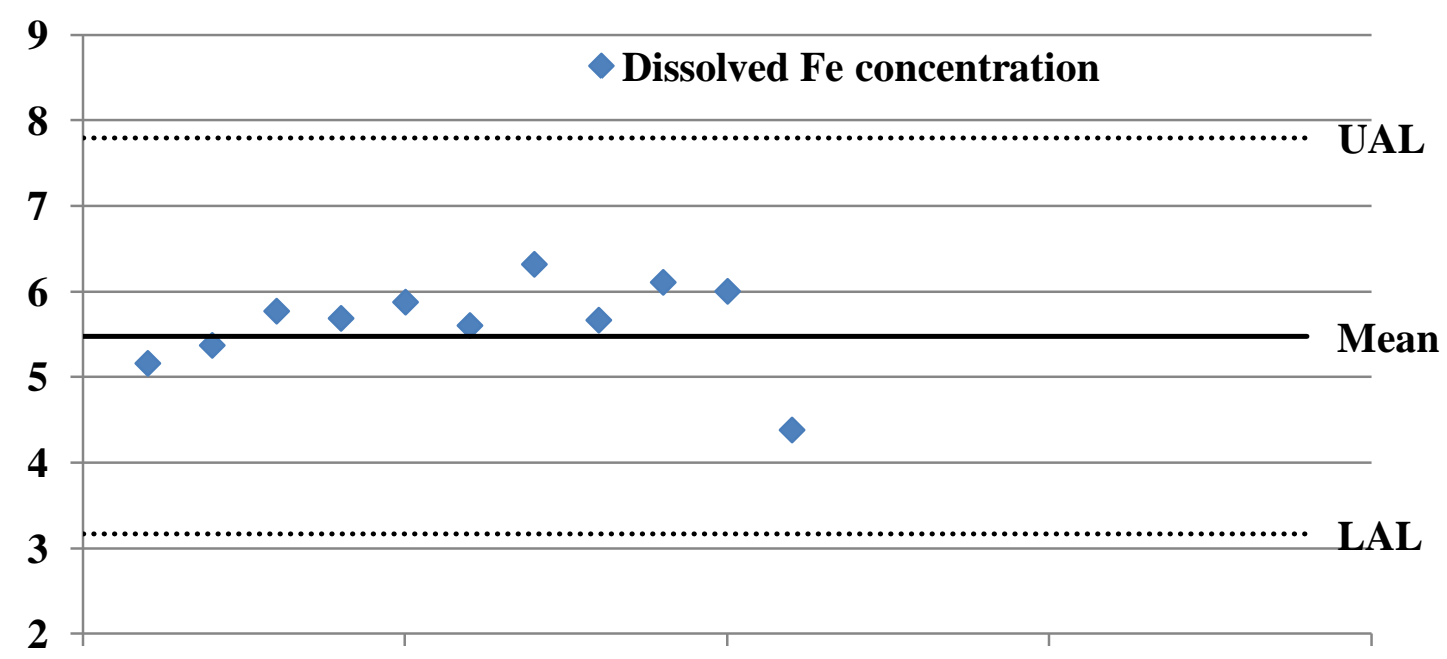

Figure A2.3 Variation of the analysis of dissolved Fe ( $5 \mathrm{mg} / \mathrm{L})$ between JuneJuly/2011 


\section{B) Uncertainty}

Using equation A2.1, [52], standard uncertainty can be calculated for dissolved $\mathrm{Cu}$, $\mathrm{Zn}$ and $\mathrm{Fe}$, as shown in tables A2.1, A2.2, and A2.3. Note that the rectangular distributions $(\sqrt{3})$ were assumed for all uncertainty sources, since no information was provided by the manufacturer regarding to the coverage factor.

By applying equation A2.2, [52], the total relative uncertainty can be calculated. The measurements of $\mathrm{Cu}, \mathrm{Zn}$ and $\mathrm{Fe}$ were associated with $4.00 \%, 5.87 \%$, and $7.83 \%$ respectively.

Standard Uncertainty $=$ Standard deviation $/ \sqrt{ } 3$

Total relative uncertainty $=\sqrt{\sum\left(\frac{\text { Standard uncetainty }}{\text { Absolute value }}\right)^{2}}$

Table A2.1 Sources and standard uncertainties associated with dissolved $\mathrm{Cu}$ measurements.

\begin{tabular}{ccc} 
Sources & Value & Standard uncertainty \\
\hline Standard solution & $1001 \mathrm{mg} / \mathrm{L}$ & 2.30 \\
Volumetric flask & $25 \mathrm{~mL}$ & 1.73 \\
Micropipette & $1000 \mu \mathrm{L}$ & 0.11 \\
FAAS & $1.20 \mathrm{mg} / \mathrm{L}$ & 0.048 \\
$\mathbf{2}$ x Measuring cylinder & $250 \mathrm{~mL}$ & 0.115 \\
Measuring cylinder & $25 \mathrm{~mL}$ & 0.058 \\
\hline
\end{tabular}


Table A2.2 Sources and standard uncertainties associated with dissolved Zn measurements.

\begin{tabular}{ccc}
\hline Sources & Value & Standard uncertainty \\
\hline Standard solution & $1000 \mathrm{mg} / \mathrm{L}$ & 1.15 \\
Micropipette & $1000 \mu \mathrm{L}$ & 0.11 \\
FAAS & $1.20 \mathrm{mg} / \mathrm{L}$ & 0.070 \\
Volumetric Flask & $25 \mathrm{~mL}$ & 0.173 \\
\hline
\end{tabular}

Table A2.3 Sources and standard uncertainties associated with dissolved Fe measurements.

\begin{tabular}{ccc}
\hline Sources & Value & Standard uncertainty \\
\hline Standard solution & $1000 \mathrm{mg} / \mathrm{L}$ & 2.30 \\
Micropipette & $1000 \mu \mathrm{L}$ & 0.11 \\
FAAS & $5.0 \mathrm{mg} / \mathrm{L}$ & 0.070 \\
Volumetric Flask & $25 \mathrm{~mL}$ & 0.39 \\
\hline
\end{tabular}




\section{D)Calibration curves}

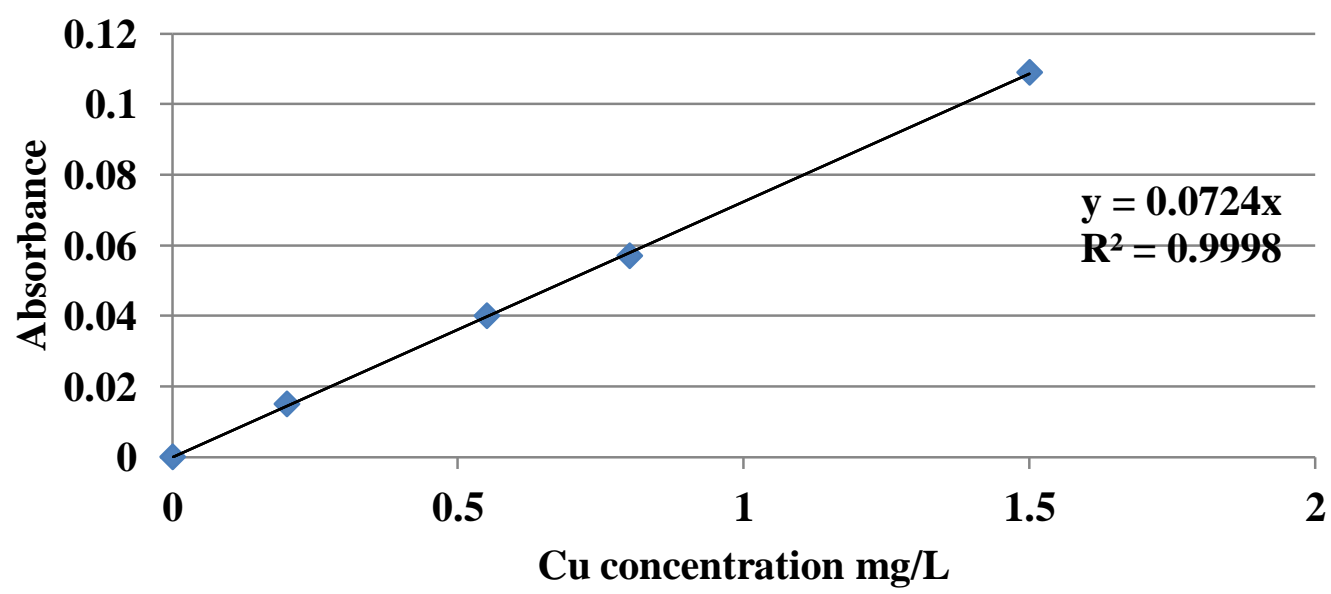

Figure A2.4 Cu calibration curve obtained by analysing 5 standards on FAAS.

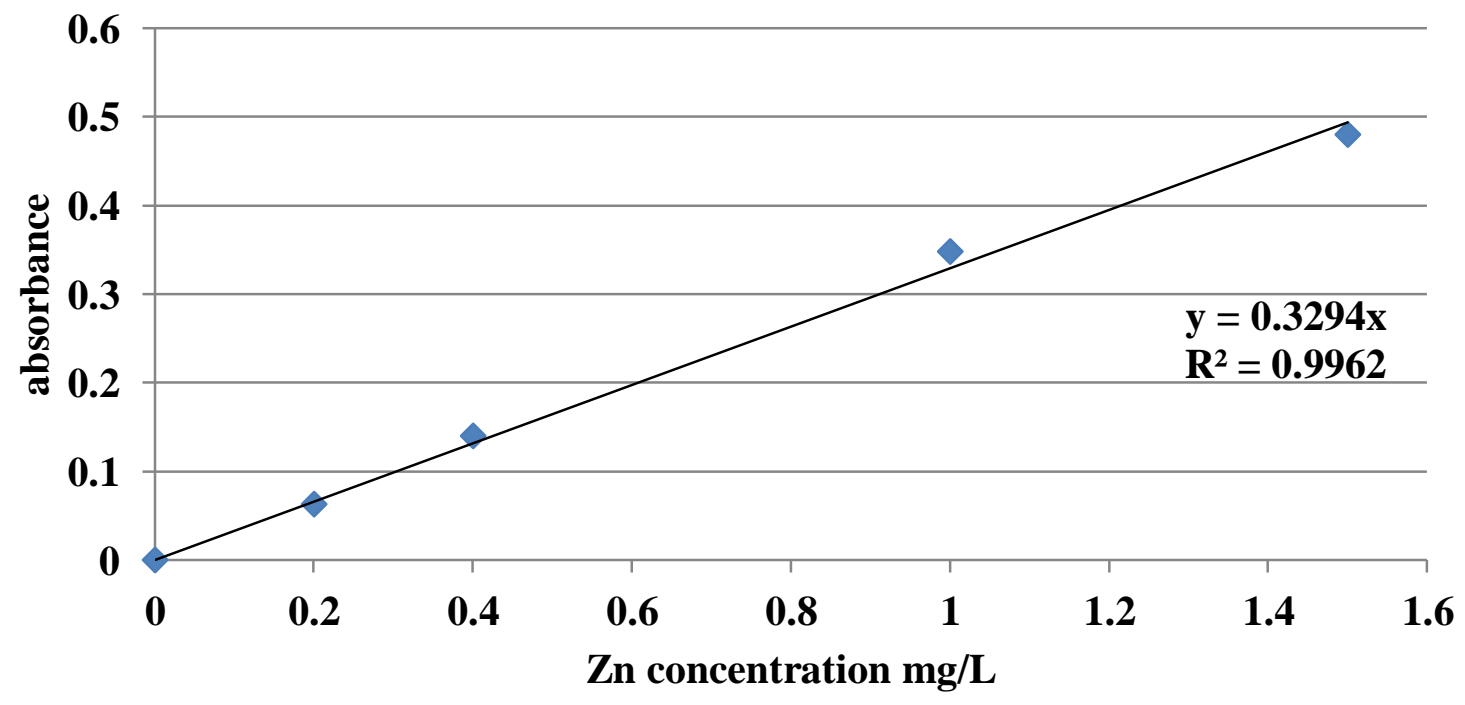

Figure A2.5 Zn calibration curve obtained by analysing 5 standards on FAAS. 


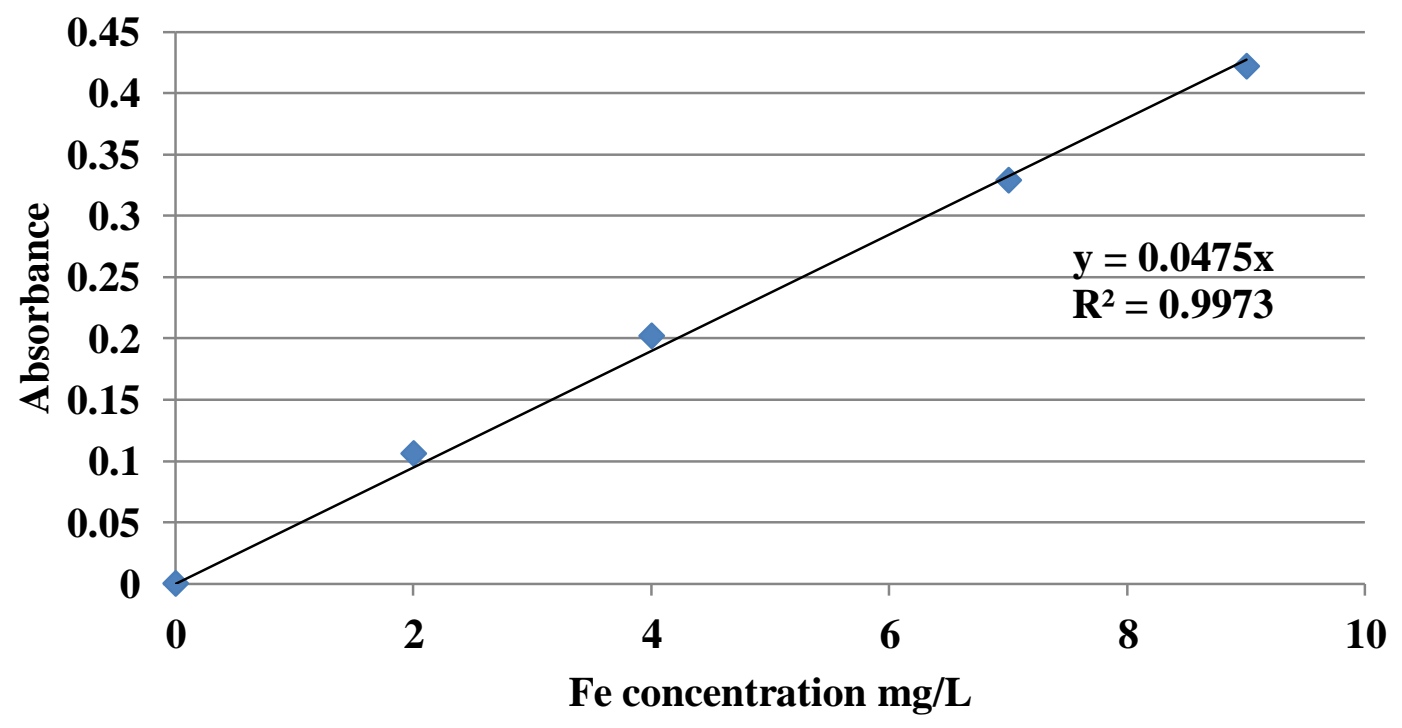

Figure A2.6 Fe calibration curve obtained by analysing 5 standards on FAAS. 


\section{Sites Coordinates}

Table A2.4 Coordinates of the monitored sites

\begin{tabular}{|c|c|c|c|}
\hline Site number & Sites name & Latitude & Longitude \\
\hline Site 1 & Wingfield Place, Porirua Stream & -41.210469 & 174.812046 \\
\hline Site 2 & 289 Middleton Road Tunnel, Glenside, Porirua Stream & -41.203140 & 174.817980 \\
\hline Site 3 & Tawa, Main Road, Porirua Stream. & -41.176924 & 174.825981 \\
\hline Site 4 & Kenepuru Drive, next to the flow monitoring station, Porirua Stream. & -41.141651 & 174.843032 \\
\hline Site 6 & Woodburn Drive Takapu Road, Takapu Stream & -41.178400 & 174.838975 \\
\hline Site 7 & Takapu Road, Takapu Stream & -41.181254 & 174.834795 \\
\hline Site 8 & Karori Park eastern, Karori Stream & -41.285639 & 174.725476 \\
\hline Site 9 & Karori Park western, a tributary of Karori Stream. & -41.287495 & 174.723388 \\
\hline Site 13 & Takarau Gorge Road, Ohariu Stream. & -41.225907 & 174.748541 \\
\hline
\end{tabular}




\section{Selected site photos}

Site 1

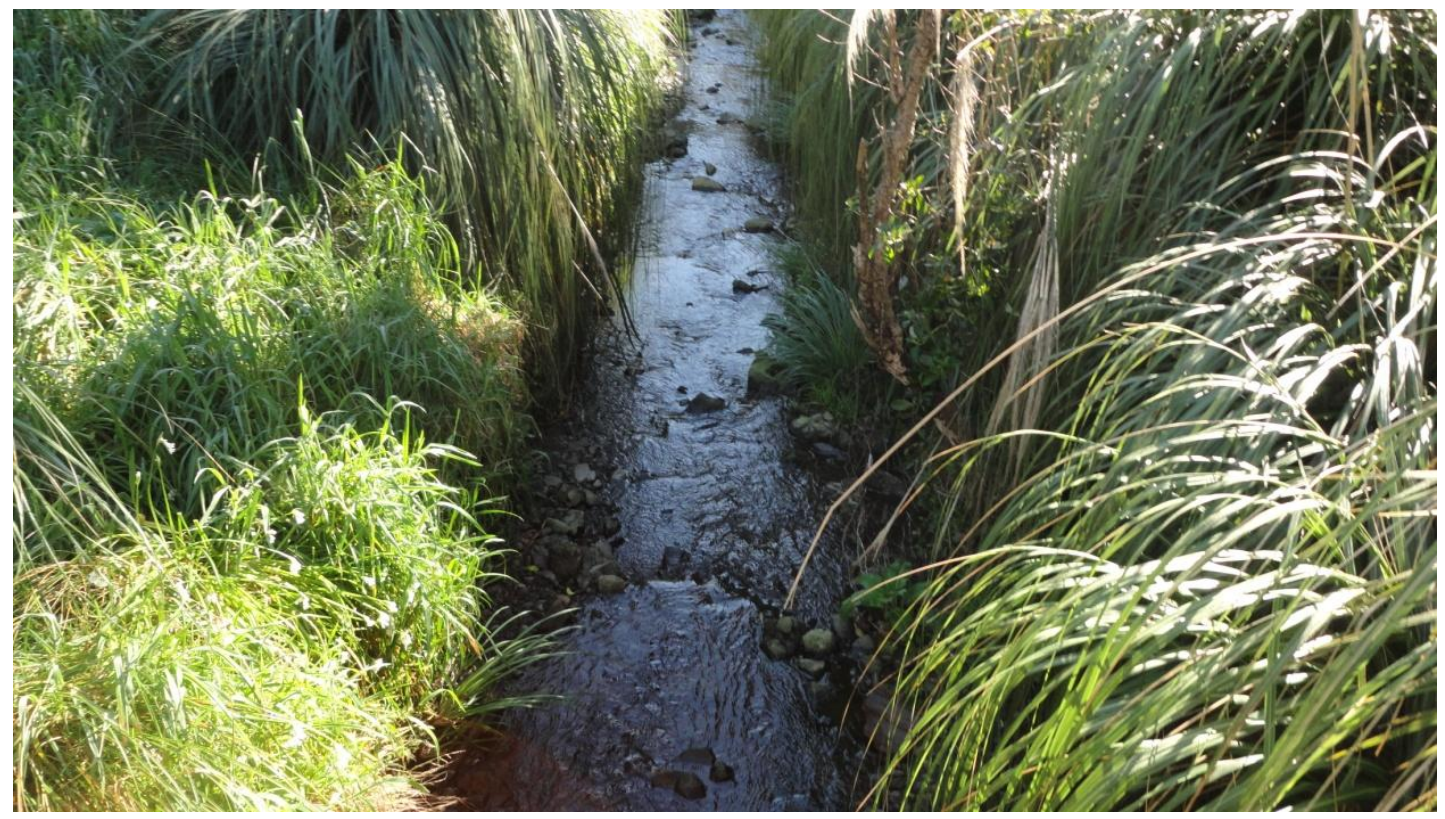

Site 2

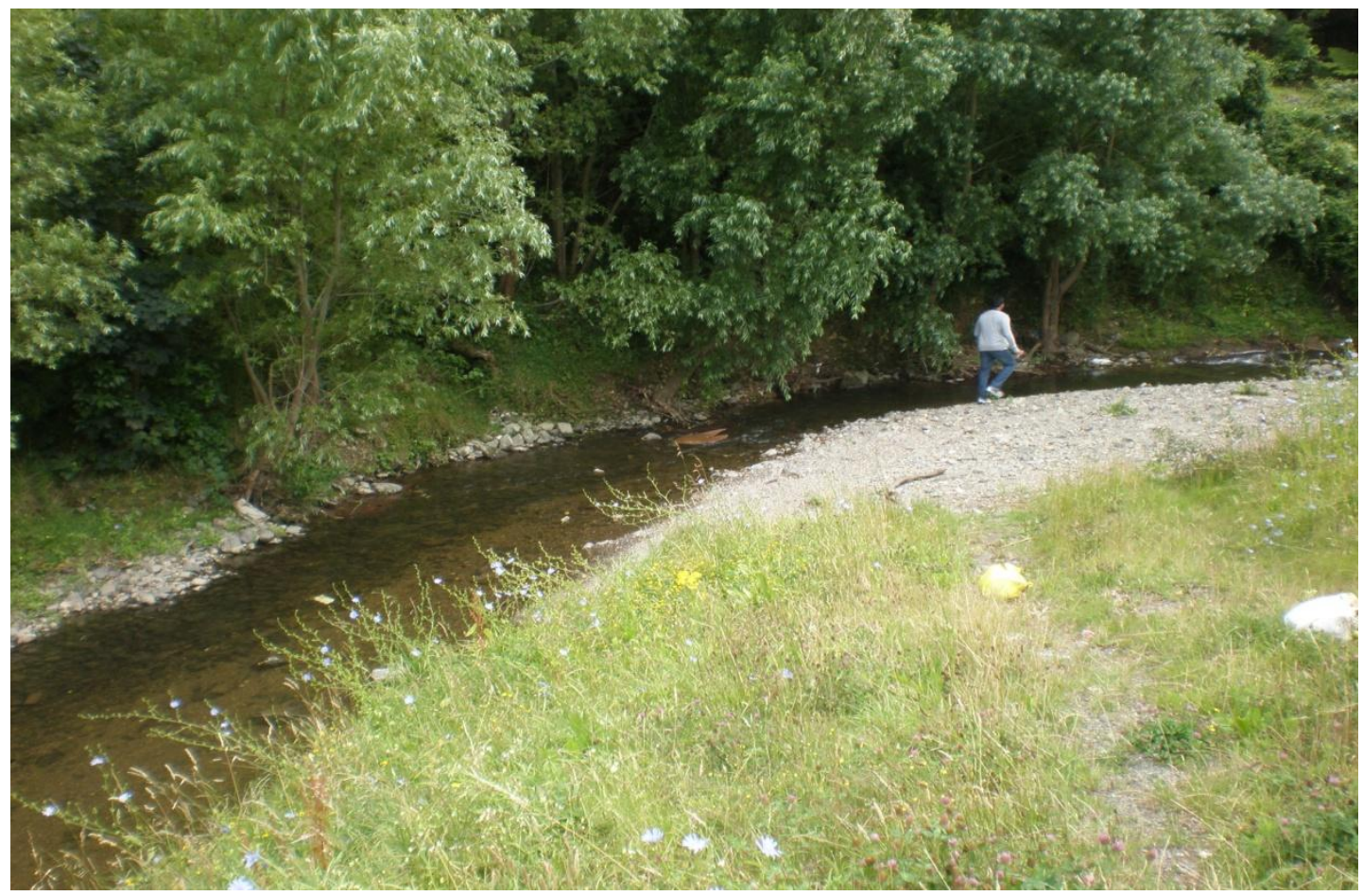


Site 3

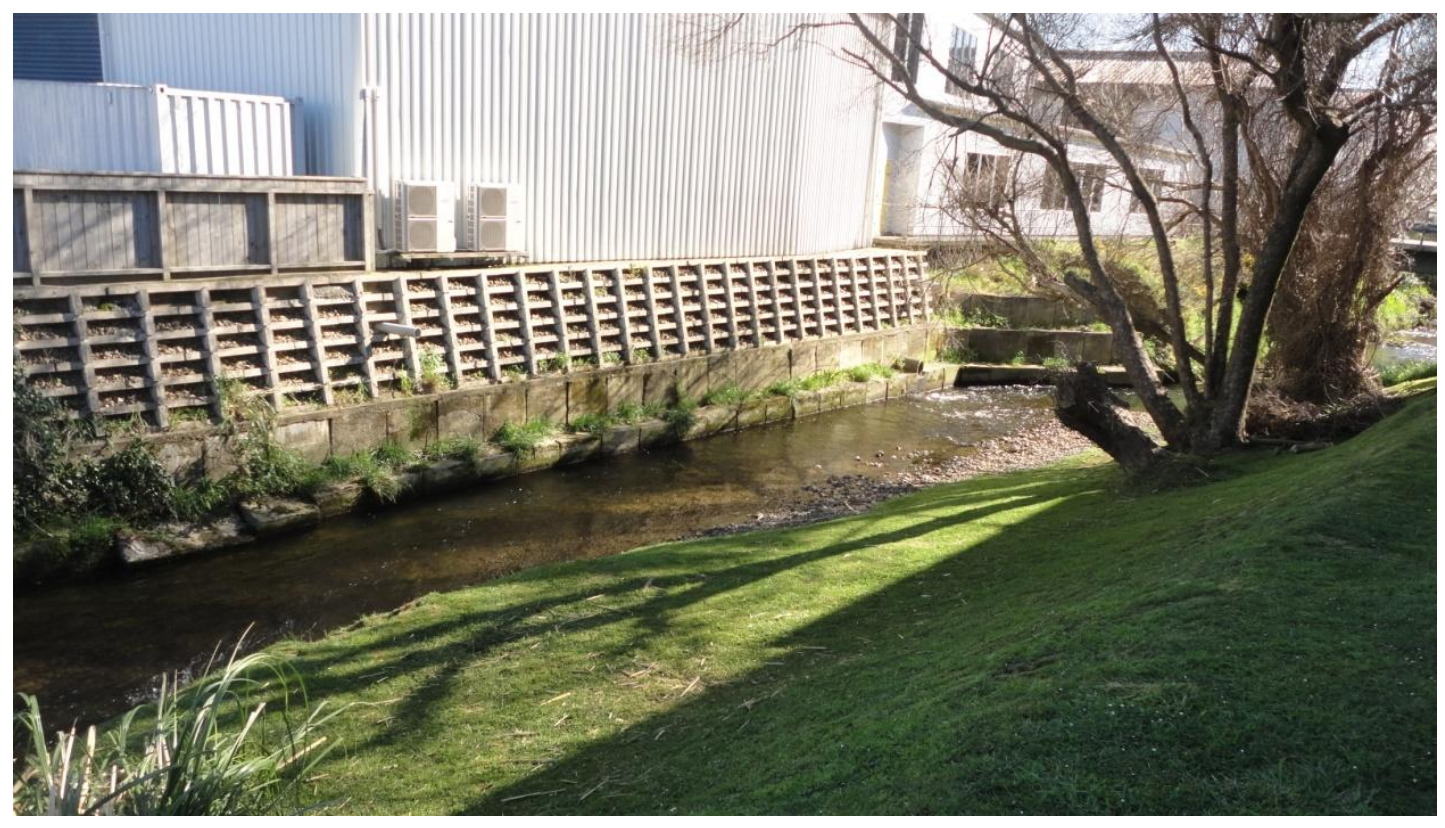

Site 4

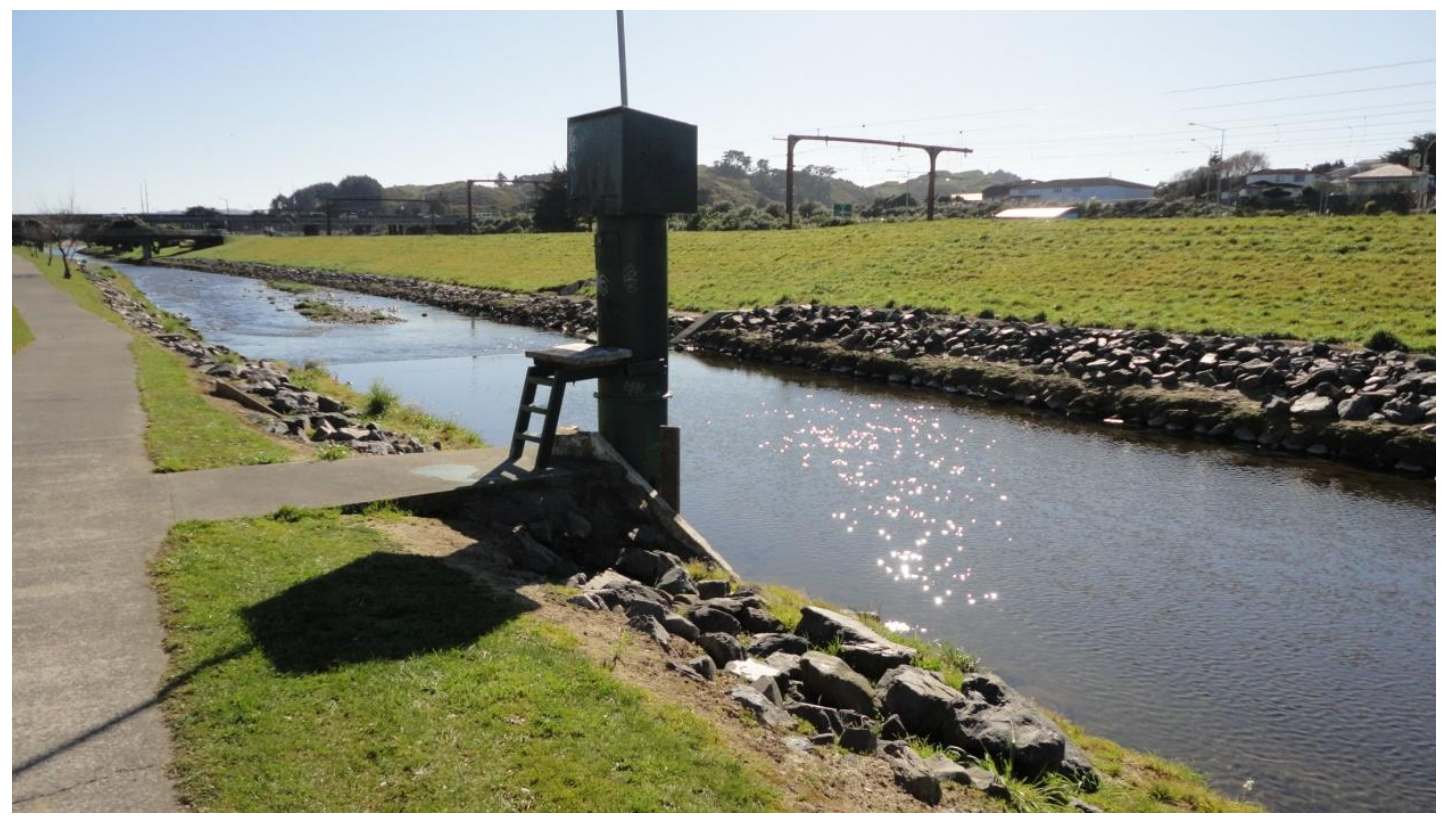


Site 5

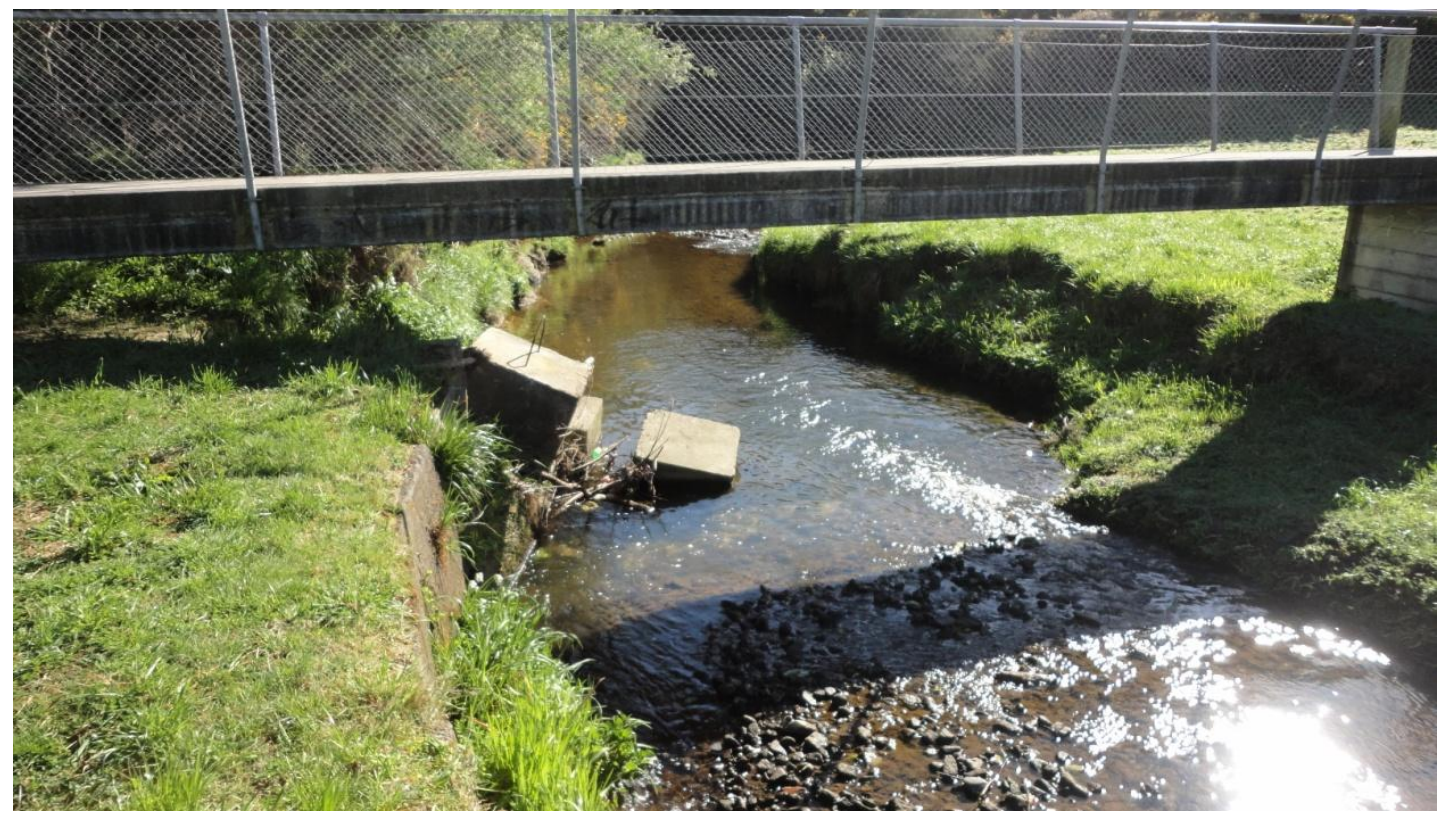

\section{Site 6}

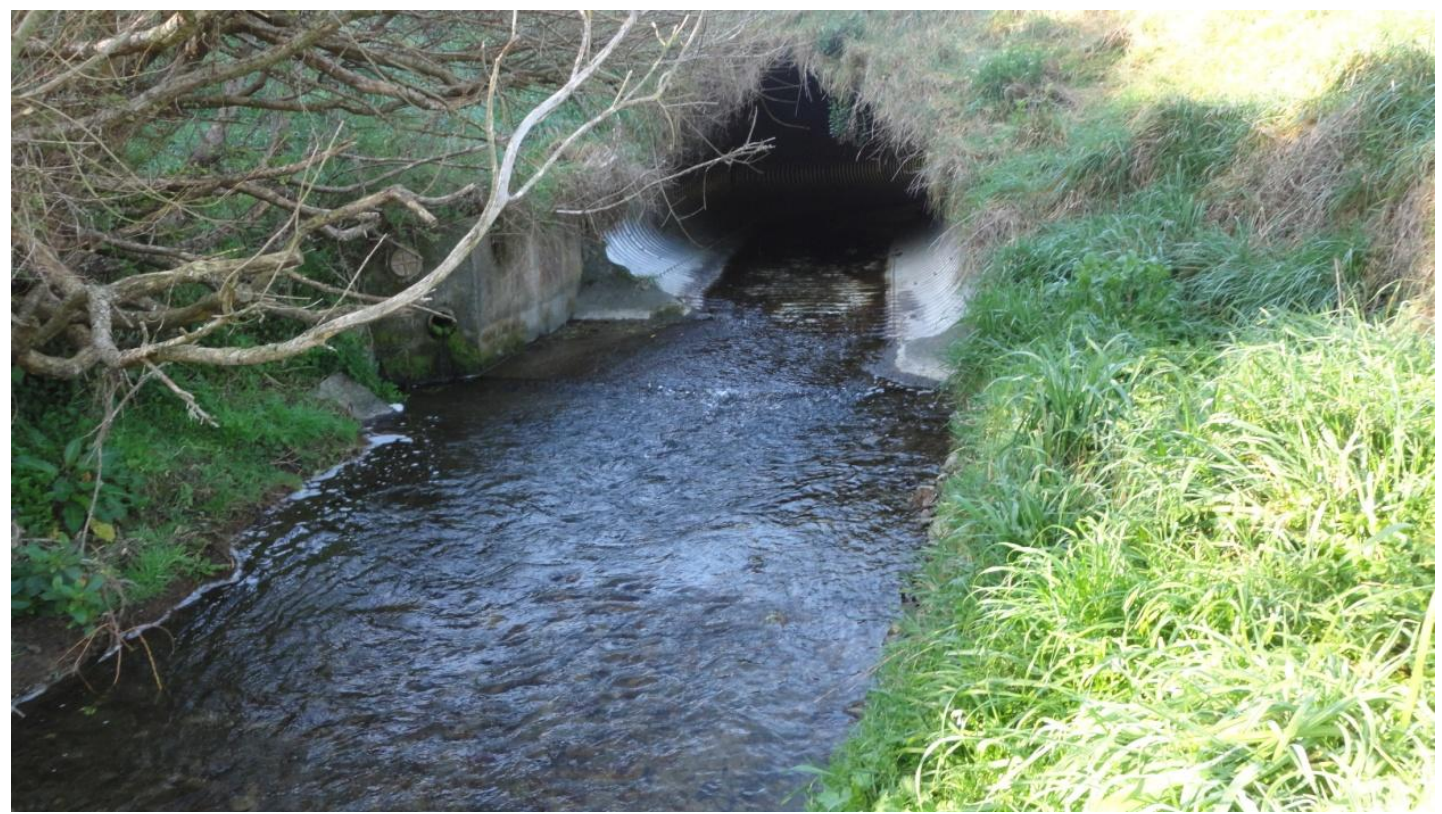


Site 7

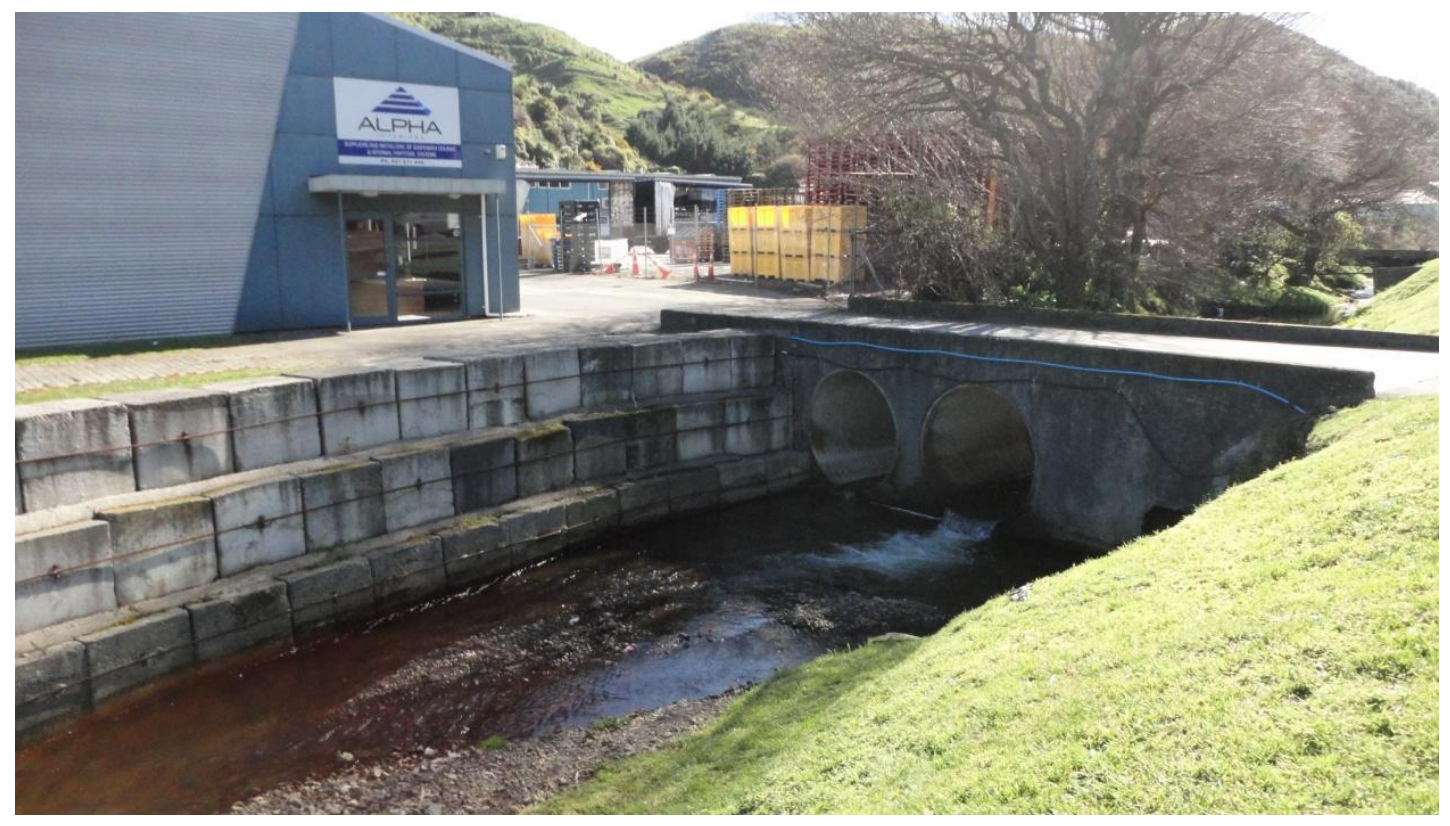

\section{Site 8}

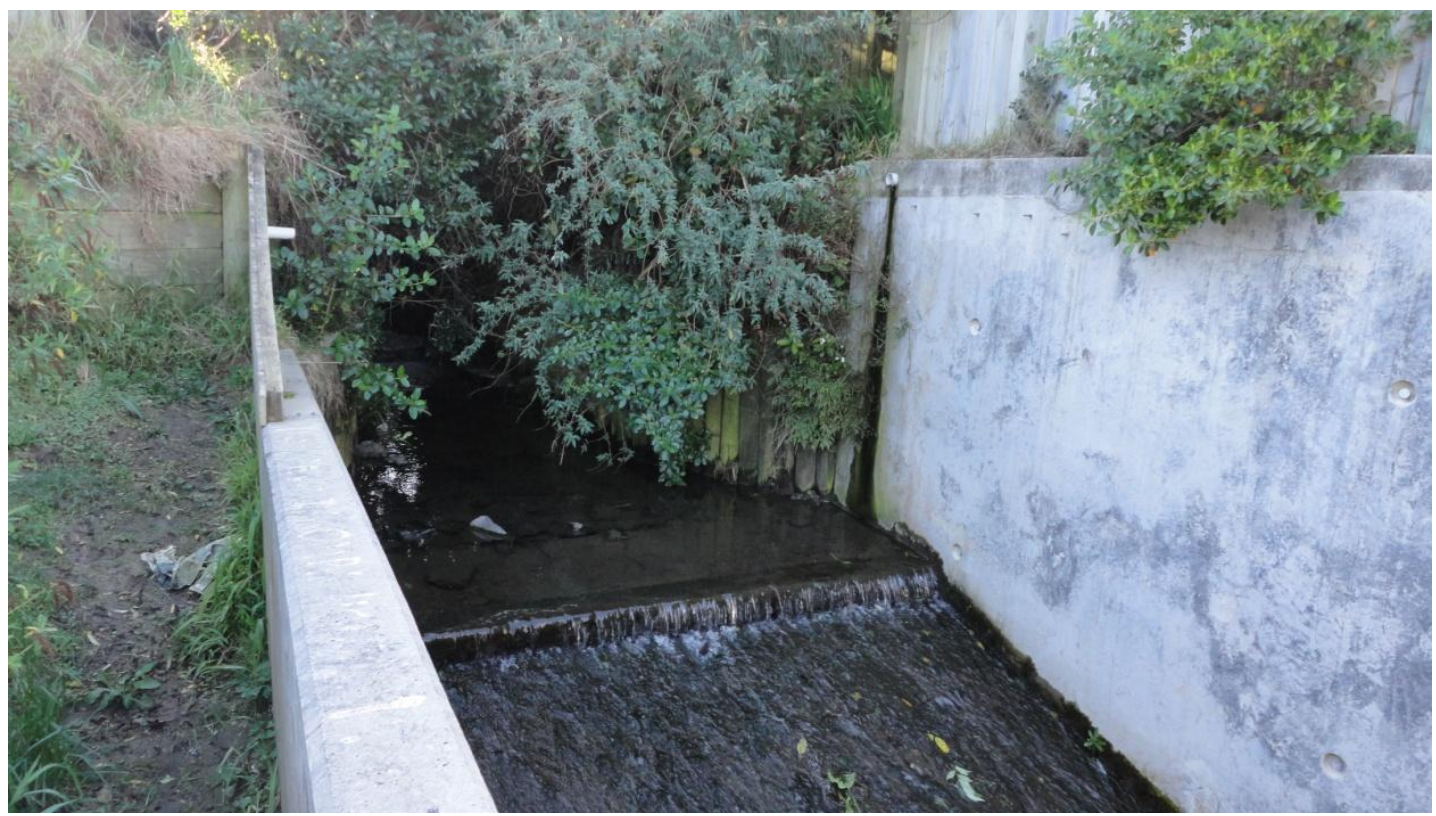


Site 9

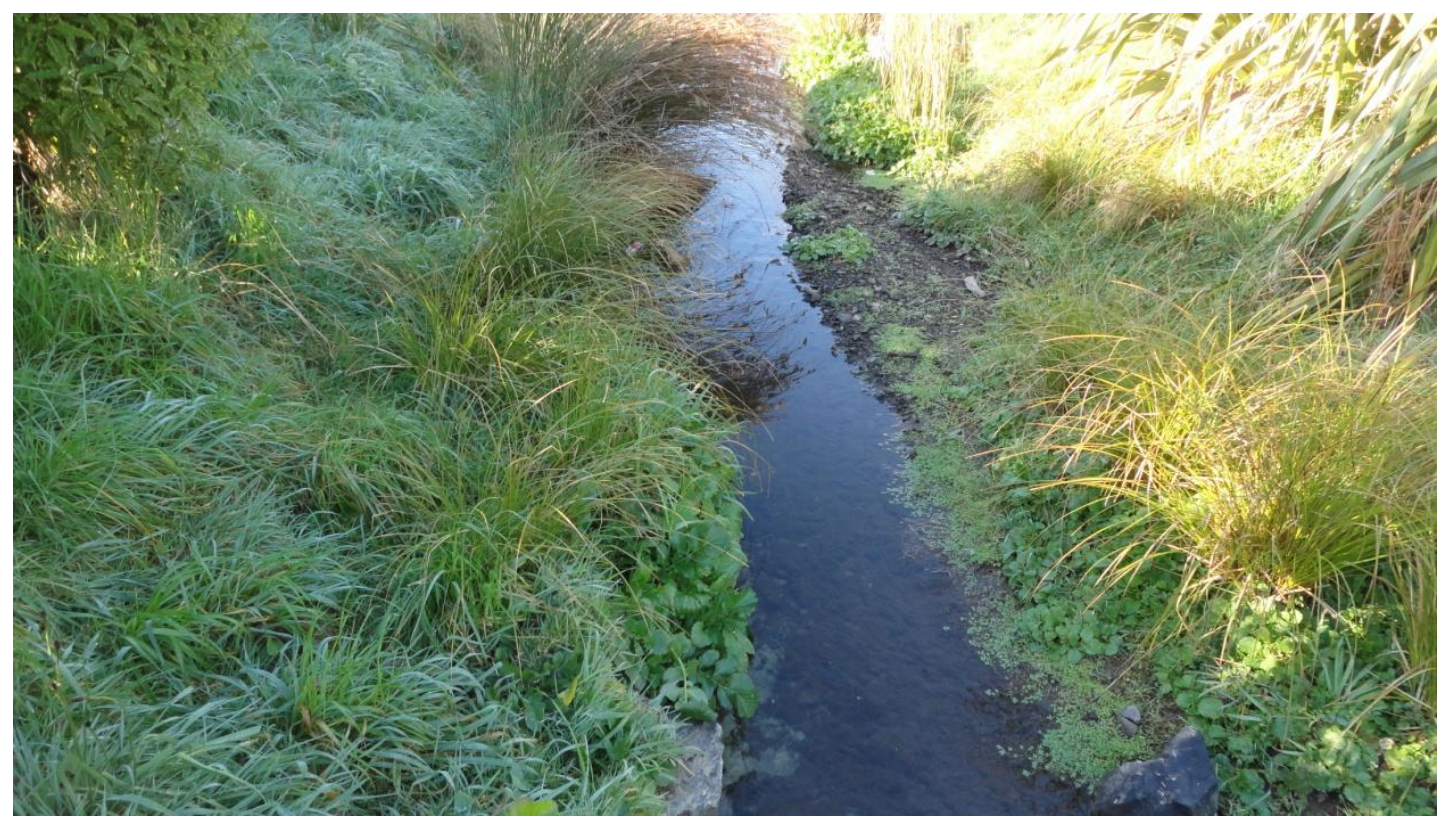

\section{Site 10}

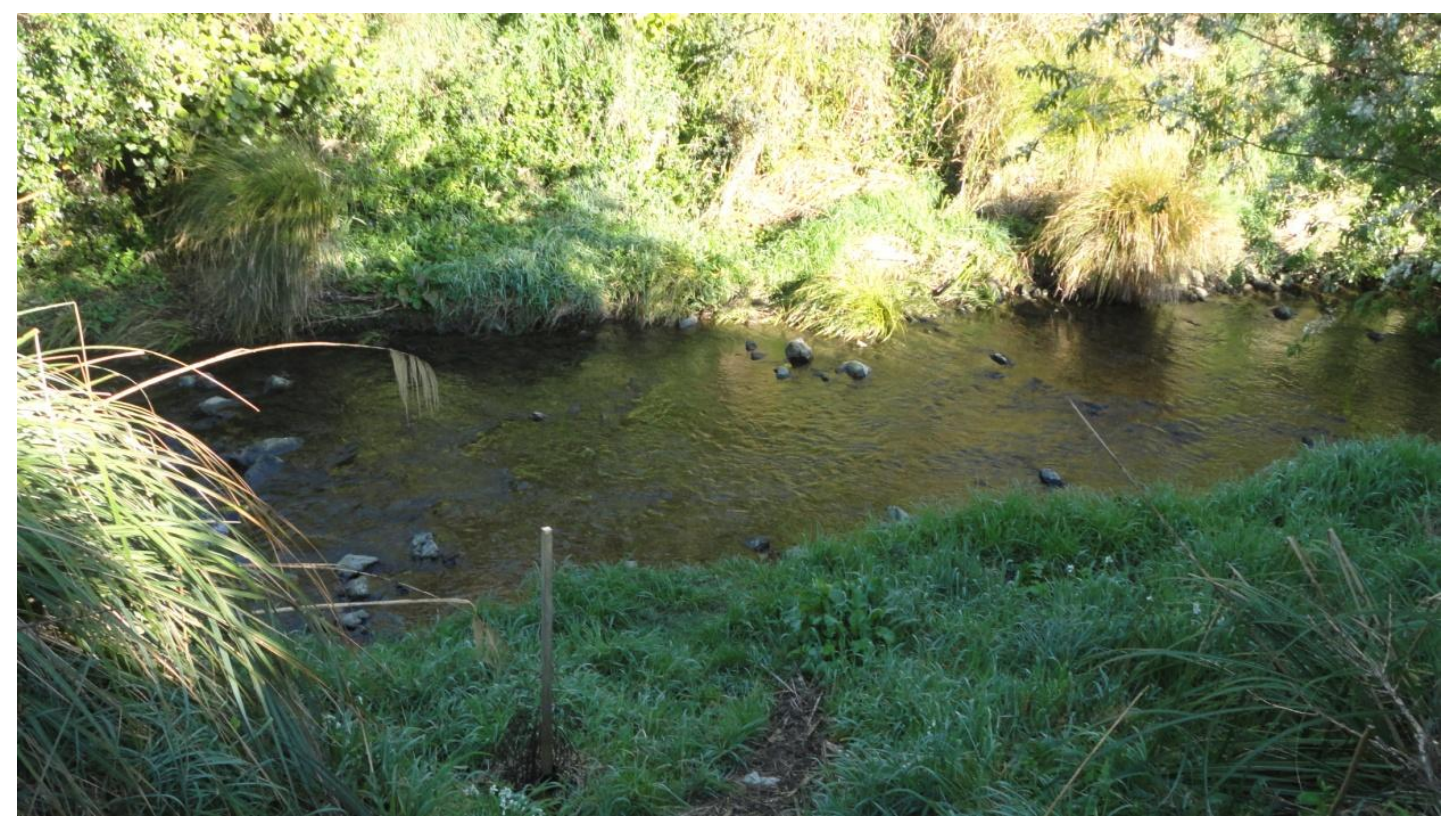




\section{Site 11}

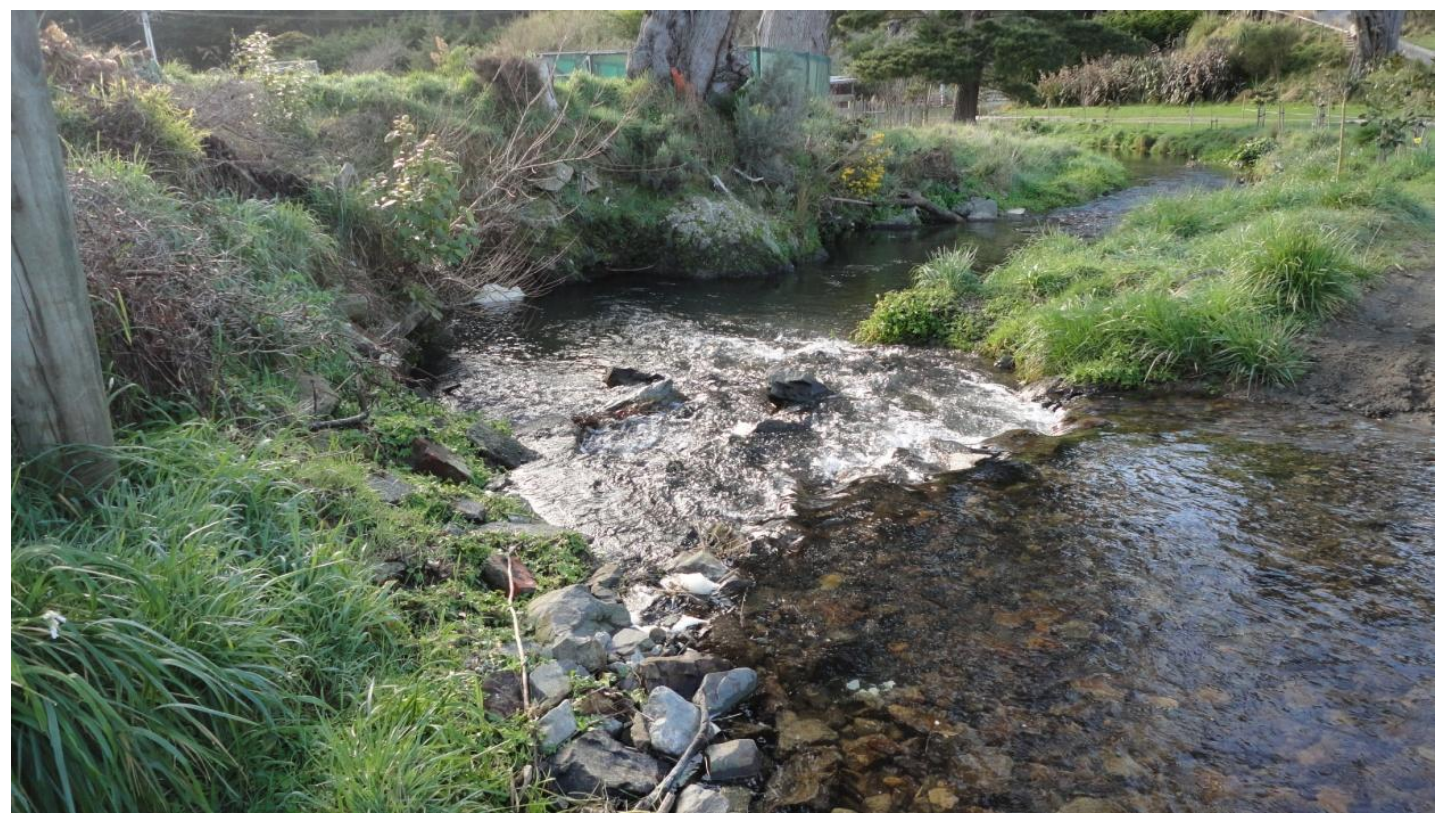

\section{Site 12}

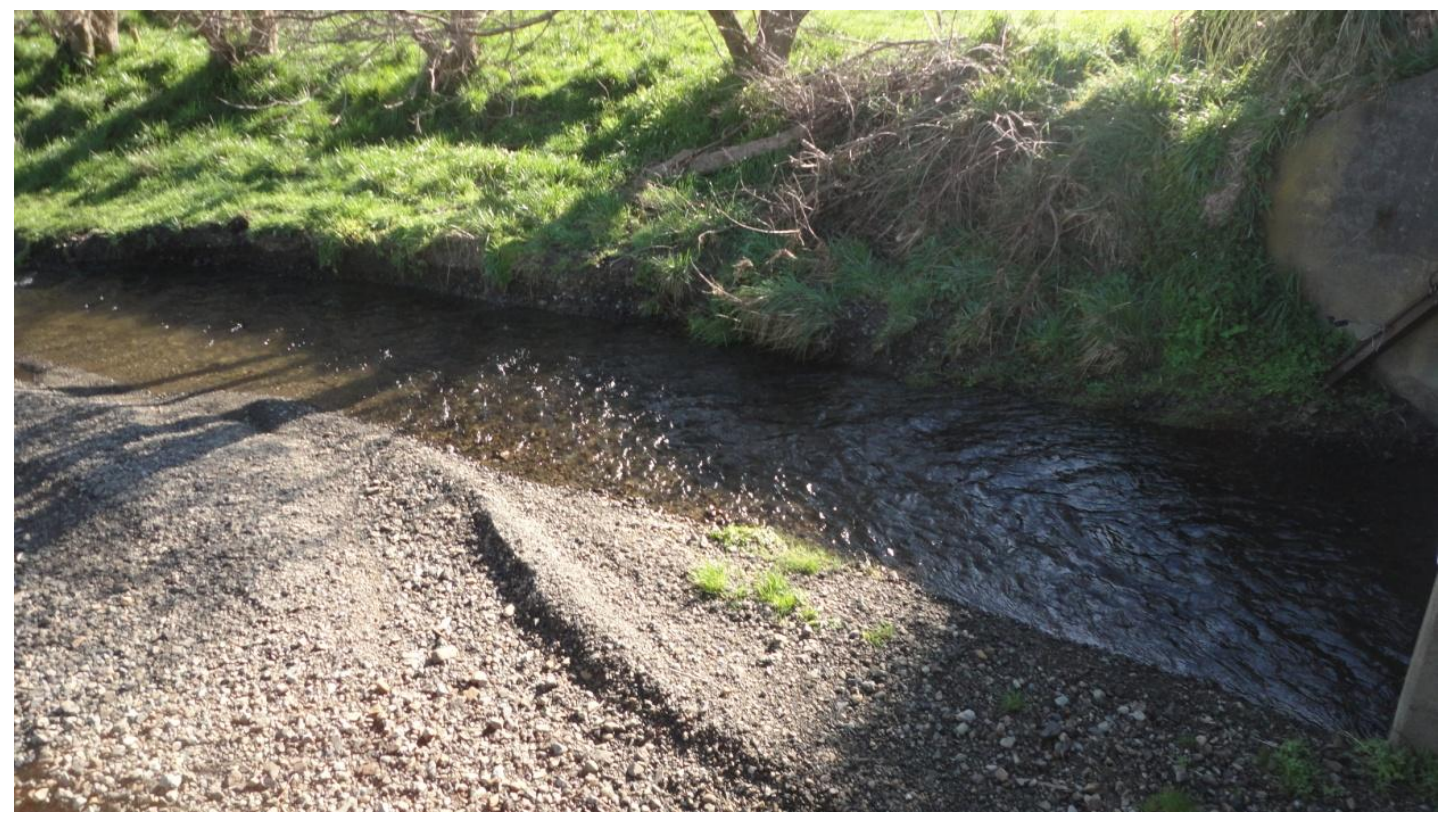

